\title{
La dimensión cultural del paisaje y el territorio en el cine rural español 1950-1959
}

Tesis doctoral presentada por AIIDA ANTONINO-QUERALT

Dirigida por VICENTE J. BENET Octubre 2019

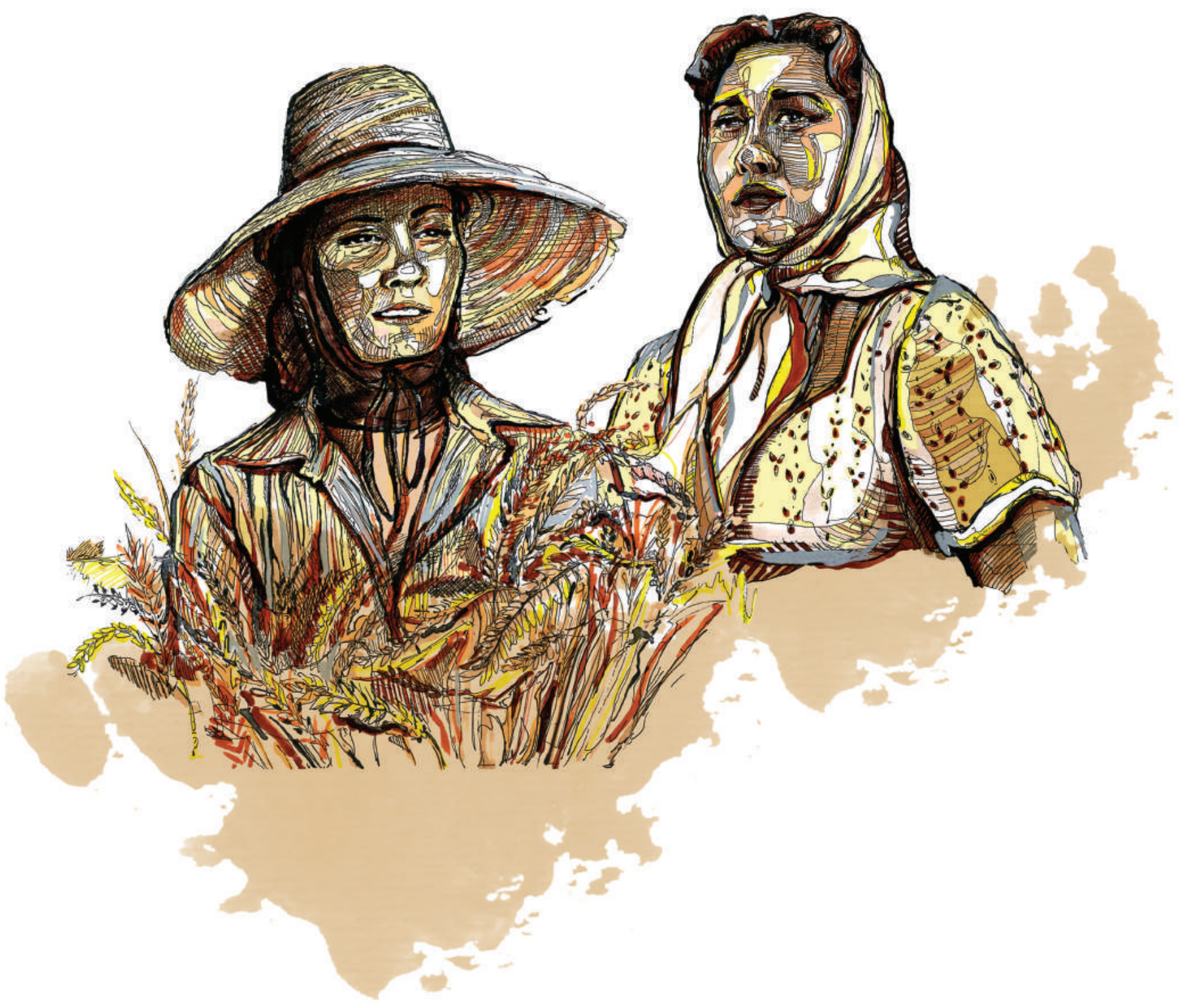





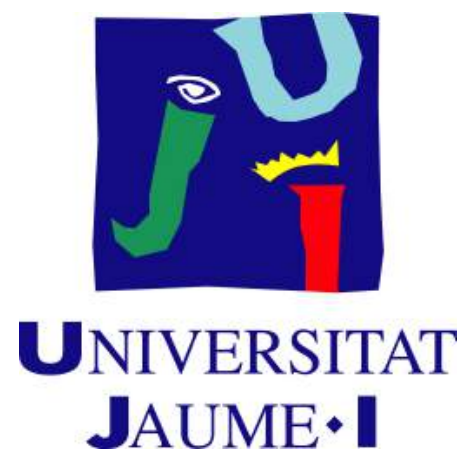

Programa de doctorat en Història i Estudis Contemporanis

Escola de Doctorat de la Universitat Jaume I

\section{LA DIMENSIÓN CULTURAL DEL PAISAJE Y EL TERRITORIO EN EL CINE RURAL ESPAÑOL 1950-1959}

Memòria presentada per Aïda Antonino-Queralt per optar al grau de doctora per la Universitat Jaume I

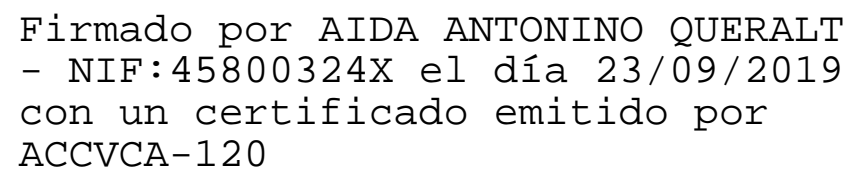

Castelló de la Plana, octubre 2019
VICENTE Firmado digitalmente por VICENTE JOSE|BENET| FERRANDO BENET| Fecha: FERRAND Fecha: $15: 46: 21+02^{\prime} 00^{\prime}$ 



\section{Finançament rebut}

Aquesta tesi doctoral s'ha realitzat amb el finançament rebut per la Universitat Jaume I a través del Programa d'ajudes predoctorals per a la formació de personal investigador, FPI-UJI PREDOC/2014/03. A més de l'ajuda E-2016/06 per a la realització d'estades temporals en altres centres d'investigació, per al personal docent i investigador de la Universitat Jaume I. Amb data 26 de gener de 2017. Destinació: School of Modern Languages, Literatures and Cultures, Royal Holloway University of London, Regne Unit. I l'ajuda E-2017/01 per a la realització d'estades temporals en altres centres d'investigació, per al personal docent i investigador de la Universitat Jaume I. 26 de gener de 2017. Destinació: Film Studies Department, King's College London, Regne Unit. 


\section{A Paco, Esther, Néstor i Raimon, els meus pilars de fonament.}

Sempre agraïda amb Vicente $\mathrm{J}$. Benet per guiar-me en la deriva d'aquest viatge pel cinema espanyol. Amb Carlos A. Cuéllar i Carlos Losilla que em motivaren a iniciar el trajecte. I amb Sarah Wright i Belén Vidal perquè em transmeteren el valor de pensar el cinema.

Als comprensius Encarna i Miguel.

Als lleials Eire, Borja, Edgar i Conrado.

A les companyes Teresa, Marina i Judith.

I als pacients Francesc i Mari Tere. 


\section{Abstract}

This dissertation shows a cultural history of cinematographic images that have tackled the Spanish countryside between 1950-1959. The theoretical framework is fueled by Anglo-Saxon studies that have looked into the spatial uses and their meanings in the processes of collective identity formulation. In the premodernism years of the Spanish society in the 1950s, the rural cinema not only witnesses the synergies that were coming about, but it is also recognized as a perpetuating agent of the collective imaginary. Its transcendence will be analyzed considering the political strategies of the Francoist regime, the state of the national cinematographic industry, and the discursive set of formulae adopted. In order to fulfill this objective, an overview of 35 rural cinema projects will be provided, with special focus on the forms of setting, landscape and territory. Specifically, case analyses will be brought to the fore for the levels of landscape in Condenados, Manuel Mur Oti, 1953; Sierra maldita, Antonio del Amo, 1954; and Cañas y barro, Juan de Orduña, 1954. As for territory, La guerra de Dios, Rafael Gil, 1953; Amanecer en Puerta Oscura, José María Forqué, 1957; and La venganza, Juan Antonio Bardem, 1958, will be analyzed. In these levels, the experience of landscape entails a cultural entity allowing the use of these films as primary sources to tackle the constellation of synergies that paved the way for the modernization of the country.

Keywords: Rural Cinema; Landscape; National Identity; 1950 Spain; Cultural History. 


\section{Resumen}

Este trabajo presenta una historia cultural de la imágenes cinematográficas que han abordado el campo español entre los años 19501959. El marco teórico se nutre de los estudios anglosajones que han abordado los usos espaciales y su significado en los procesos de formulación de identidades colectivas. En el momento de premodernización de la vida española de los años cincuenta el cine rural no solo testimonia las sinergias acaecidas sino también se legitima como agente perpetuador de un imaginario colectivo. Su trascendencia será analizada atendiendo a las estrategias políticas del régimen franquista, al estado de la industria cinematográfica nacional y las fórmulas discursivas que adoptó el cine rural. Con el propósito de cumplir este objetivo se ofrecerá una panorámica por treinta y cinco proyectos de cine rural estructurada en torno a las formas de setting, landscape y territory. Centrándose los análisis de caso en los estadios de 'paisaje' en Condenados, Manuel Mur Oti, 1953, Sierra maldita, Antonio del Amo, 1954 y Cañas y barro, Juan de Orduña, 1954. Y de 'territorio' en La guerra de Dios, Rafael Gil 1953, Amanecer en Puerta Oscura, José María Forqué, 1957 y La venganza, Juan Antonio Bardem, 1958. Se considera que en estos estadios la experiencia del paisaje constituye una entidad cultural permitiendo el uso de estas películas como fuentes primarias para abordar la constelación de sinergias que dieron paso a la modernización del país.

Palabras clave: Cine rural; Paisaje; Identidad nacional; España 1950; Historia cultural. 


\section{ÍNDICE DE CONTENIDOS}

INTRODUCCIÓN..

1. Aspectos fundamentales de la política y la cultura española de los años 50

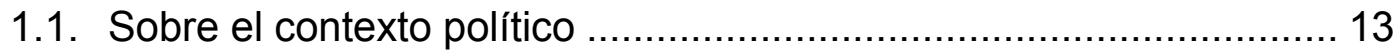

1.1.1. La conciencia social de vacío ........................................... 16

1.1.1. Tensiones en el estancamiento del falangismo ..................... 18

1.1.2. Diplomacia hispano-norteamericana. Estados Unidos como

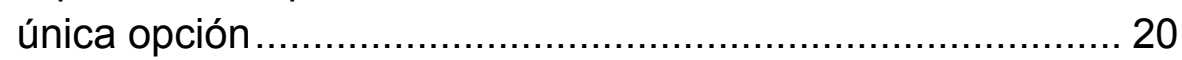

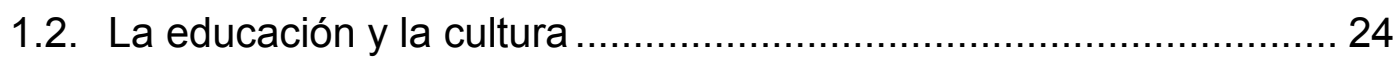

1.2.1. Las políticas educativas de Joaquín Ruiz-Giménez ............... 24

1.2.2. Las derivas del intervencionismo artístico-cultural franquista 25

1.2.3. Referentes para un arte propio ........................................... 29

1.2.4. El Informalismo, la vanguardia propiamente española ........... 33

1.2.5. El intercambio cultural de la alianza hispano-norteamericana 35

1.3. La consideración franquista del campo español............................. 37

1.3.1. El plan de reconstrucción nacional del régimen franquista.... 40

\section{Aspectos fundamentales de la cinematografía española de los años}

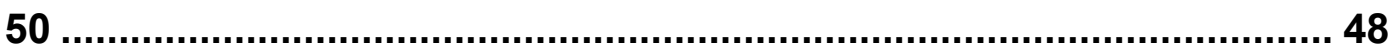

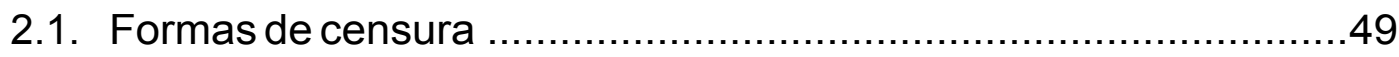

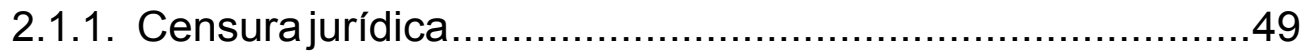

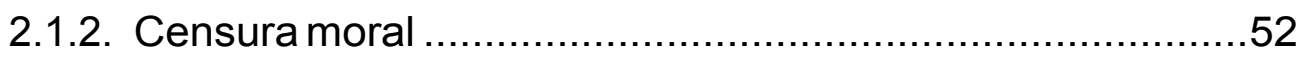

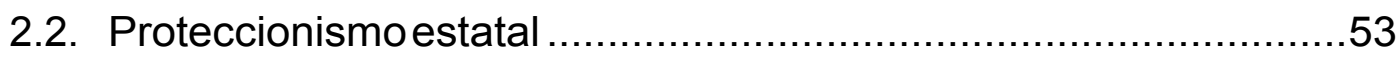

2.3. Las políticas de García Escudero .................................................... 56

2.4. La industria cinematográfica nacional .......................................... 59

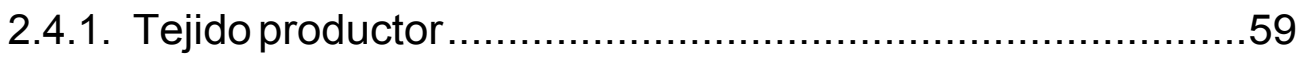

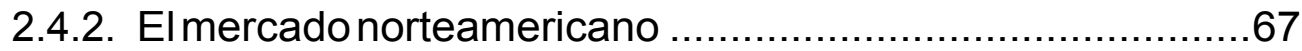

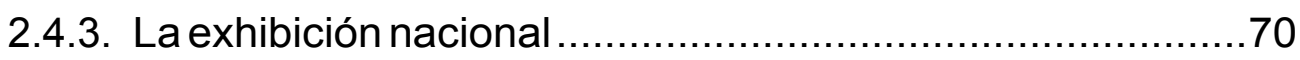

2.4.4. La coproducción cinematográfica ...................................... 71

2.5. Nuevas fórmulas para una cinematografía nacional ...................... 72 
2.5.1. El Neorrealismo como referente para el cine español 76

2.5.2. El IIEC y el cine español .......................................... 79

2.5.3. Las Conversaciones de Salamanca, crisol contestatario

2.5.4.1. Las conclusiones de las Conversaciones de Salamanca

3. El paisaje, entidad cultural 97

3.1. Sobre la genealogía del paisaje 97

3.1.1. La representación artística del entorno rural 101

3.1.2. El viaje en la construcción moderna del paisaje 103

3.1.3. Ladualidad campo-ciudad 104

3.1.4. El entorno rural, espacio de identidad colectiva 108

3.2. El mito de España. 112

3.2.1. La llamada exótica del Quijote. La mirada romántica del paisaje español

3.2.2. Más allá del Quijote. La mirada autóctona de la España rural

3.2.3. Detrás de donde todos miran. La contra-mirada a la España rural.

3.2. La crisis finisecular y la reinvención de Castilla 124

3.3.1. El regeneracionismo en la eclosión de la conciencia nacional.

3.3.2. La Generación del 98 y el paisajismo español 130

3.3.3. La España negra en pintura. 140

3.4. Aspectos fundamentales de la España rural 144

3.4.1. La dimensión social del entorno rural 144

4. El cine rural español, 1950-1959 149

4.1. Los usos cinematográficos del espacio, el paisaje y el territorio.....150

4.1. Las Cinco historias de España de Muñoz Suay ........................... 156

4.2. Las fórmulas del cine rural español 164

5. El entorno rural español. Paisaje del drama rural

5.1. La dimensión telúrica del arquetipo femenino 184

5.2. Condenados, 1953 , el paisaje castellano 191 
5.3. Sierra maldita, 1954, el paisaje andaluz ................................ 195

5.4. Cañas y barro, 1954, el paisaje valenciano .............................. 199

5.5. Análisis comparado de los arquetipos femeninos rurales ............ 203

5.6. El paisaje rural en clave identitaria .................................... 221

6. El entorno rural español. Territorio de conflicto social ..................... 226

6.1. El trabajo en la definición del estamento campesino................... 227

6.2. Amanecer en Puerta Oscura, 1957, territorio pretérito .................. 227

6.3. La guerra de Dios, 1953, territorio evangelizado...................... 233

6.4. La Venganza, 1957, territorio de labranza.................................. 241

6.4.1. El drama rural inicial ............................................... 243

6.4.2. La deriva social final ............................................... 247

6.4.2.1.Análisis formal de los episodios sociales ................249

6.5. La dimensión social del territorio rural .......................................261

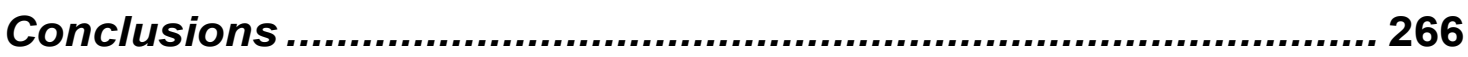

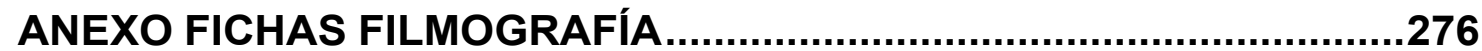

A. BIBLIOGRAFÍA ....................................................... 284

B. REVISTAS Y PERIÓDICOS .....................................................296

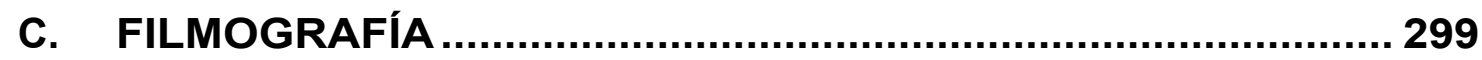




\section{INTRODUCCIÓN}

Esta tesis doctoral tiene su origen en el interés por lo rural que empecé a cultivar a raíz del encuentro por azar con Azarías, el personaje de Francisco Rabal en Los Santos Inocentes de Mario Camus, que supuso un punto de inflexión en mi relación con la industria cinematográfica. Hasta el momento había sido una consumidora acomodada a los productos más accesibles en salas de cine y televisión, con excepciones puntuales de cine clásico hollywoodiense, aunque sabía, por los profesores de cine de la licenciatura de Historia del Arte, que había otro cine denominado de autor, que abordaba las cuestiones sociales de manera diferente. En definitiva, y más allá de etiquetas, un cine como el de Camus, que golpeaba la conciencia crítica de aquellas espectadoras dispuestas a entregarle su tiempo. Empecé a preguntarme por qué, cómo y con qué finalidad Víctor Erice, Montxo Armendáriz o Carlos Saura dedicaban los recursos de un proyecto cinematográfico a temáticas de lo rural, partiendo de la ignorancia hecha prejuicio que este era un cine con menor protagonismo en el circuito de distribución y también en la historia del cine.

En mis trabajos final de máster en la Universitat de València, 2013, y la Universitat Pompeu Fabra de Barcelona, 2014, analizaba la construcción de los arquetipos rurales de películas estrenadas durante los años ochenta preguntándome por su impacto en el imaginario colectivo. En aquel momento no era plenamente consciente de la trascendencia metodológica de mis análisis fílmicos conjugados con una historia de los agentes contextuales participantes hasta que encontré una metodología y una línea de trabajo que me ayudó a concebir mi investigación: la historia cultural de las imágenes cinematográficas.

Fascinada por esta dimensión de la historia y decidida a seguir profundizando en la construcción del imaginario rural cinematográfico, fijé con mi director el que sería mi corpus de trabajo doctoral: el cine rural de la década de los años cincuenta. A su vez establecimos tres hipótesis de 
partida. La primera de ellas referida a la importancia de este período en el proceso modernizador español, lo cual equilibra la consideración del análisis histórico al análisis de las imágenes cinematográficas.

La segunda de las hipótesis tiene que ver con la validez de los productos culturales para abordar el estudio de un hecho de la historia. Y que remite a las líneas metodológicas en las que reinterpretan la historia cultural de las imágenes autores como Vicente Benet, al defender que:

"El cine refleja nuestra sociedad, y a partir de ella, los valores, las ideas, los iconos, las visiones del mundo (casi siempre enfrentadas) y las fantasías que han servido para reconocernos. Y, por supuesto, los acontecimientos históricos, las resistencias y los traumas producidos por la incorporación de España a la senda de la modernidad ${ }^{1}$."

Y de Marco Ferro por cuanto considera las películas "no como obra de arte, sino como un producto, una imagen objeto cuya significación va más allá de lo puramente cinematográfico; no cuenta sólo por aquello que atestigua, sino por el acercamiento socio-histórico que permite"”.

La última hipótesis se sitúa en la línea de pensamiento de Serna y Pons por la que "existirán tantas visiones como épocas y grupos sociales, esto son culturas entendidas como el repertorio común de referencias y evidencias, [...] vasta gama de significados colectivos que sirven para facilitar la relación y la comprensión ${ }^{3 "}$ entre individuos. La saturación de las grandes Historias, y particularmente las que atañen al cine español, nos conduce a proponer aquí un espacio desde el que construir un relato de lo rural en el cine español.

Este trabajo propone un recorrido analítico-reflexivo sobre la producción cinematográfica española de la década de los cincuenta que abordó la representación del espacio rural. De las ideas expuestas hasta el momento se concluye, por tanto, que el estudio del cine rural como fenómeno sitúa esta

\footnotetext{
${ }^{1}$ Benet, 2012: 15.

2 Ferro, 1995: 39.

${ }^{3}$ Serna; Pons, 2005: 11.
} 
investigación en el marco de la historia cultural entendida "como la parte de la historia dedicada a observar los procesos de cambio social a través de los productos culturales ${ }^{4 \prime}$.

En el proceso de construcción identitaria de una comunidad intervienen diferentes factores, entre los que no resultan secundarios los productos culturales. Estos actúan como transcripción de unas visiones concretas que resultan, para el historiador contemporáneo, las más interesantes herramientas de aproximación a su materia de estudio por cuanto han interactuado con las políticas locales en que tuvieron lugar ${ }^{5}$. Pintura, literatura, fotografía y cine constituyen "las huellas materiales en cuyo soporte está un pensamiento expresado o el vestigio de un acto emprendido ${ }^{6 "}$. $Y$ en el caso concreto del cine, que García Carrión aborda como elemento participante de la cultura de masas, juega un papel destacado como agente perpetuador de la imagen -identidad- de un colectivo "ya que ofrece una serie de narrativas, imágenes y arquetipos que hacen reconocible, en un tiempo y

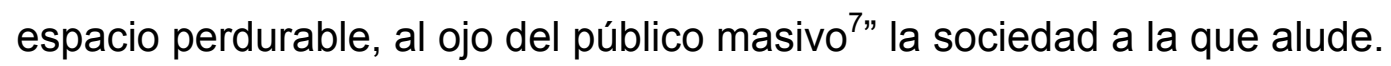

La elección del período de los años cincuenta se debe a su importancia como período de transformación, léase de contradicciones en los términos empleados por la profesora Carmen Arocena ${ }^{8}$, de una España postrada tras el trauma de la Guerra Civil frente a una España en aras de modernización que reclamaba su sitio en el mapa internacional. Una confluencia de sinergias entre el inminente pasado y el apremiante futuro registrada en el corpus fílmico de este estudio. $Y$ es que las imágenes cinematográficas a la vez que remiten a fórmulas estéticas poseen un pensamiento concreto, convirtiéndose en marcas referenciales para la historiografía por su condición de agentes esenciales en los procesos de creación ideológica e imaginativa.

\footnotetext{
${ }^{4}$ Ibídem.

${ }^{5}$ En la línea de Richardson, 2002:15.

${ }^{6}$ Serna; Pons, 2005: 13.

${ }^{7}$ García Carrión, 2013:196.

${ }^{8}$ Castro de Paz et alii, 2005: 79-129.
} 
A la condición cultural del cine y el lapso temporal escogido cabe añadir el factor del entorno rural y su traslación artística. En primer lugar dicho ejercicio remite, necesariamente, a la tradición paisajística, práctica surgida en el ámbito pictórico ante el fenómeno de observación, y con ello de ordenación, que los sujetos-pintores realizaban sobre un objeto-naturaleza. El ejercicio paisajístico "corresponds to the form of our experience of it, with the latter including representations of the different personal, cultural, and social functions it can associate to or serve ${ }^{9 "}$. Un hecho que comporta otra de las hipótesis de partida de este trabajo, las obras objeto de análisis son ficciones cinematográficas realizadas por sujetos originariamente ajenos al entorno rural. No obstante, la razón de ser de esta investigación no es ofrecer un análisis sociológico en términos veristas, ni escribir la historia del cine español. El objetivo es analizar un fragmento de la sociedad y la cultura de la España del siglo XX a partir de las imágenes cinematográficas de ruralidad que permanecen en la memoria colectiva asentándose como testimonio de un tiempo pasado. Imágenes que funcionan como vía de acceso que "nos llevan a aquel mundo que hemos perdido, lo cual es ya, en sí mismo, una exploración de historia propiamente cultural ${ }^{10 " .}$.

El campo español constituye un marco común de referencias estéticas, culturales y, por extensión, identitarias. La traslación cinematográfica del espacio natural remite a los estudios sobre la representación y los usos espaciales y sus significados. Un tema de estudio ampliamente tratado en el ámbito anglosajón cuyos trabajos conforman el marco teórico de este análisis. El objetivo es demostrar como las imágenes que ponen de manifiesto los usos del espacio rural "are not 'a reflection of deeper cultural forces' but 'a consequence of the various practices surrounding and investing in the resources it [landscape] provides ${ }^{11 "}$.

\footnotetext{
${ }^{9}$ Lefebvre, 2006: xv. "Corresponde a la forma de nuestra experiencia [del entorno] la cual incluye la representación de las funciones personales, culturales y sociales que se le pueden asociar". Traducción de la autora.

${ }^{10}$ García, 1992: 33.

${ }^{11}$ Mitch Rose Gathering 'Dreams of Presence': A Project of the Cultural Landscape. A partir de Davies, 2012: 3-4. "No son [solo] el reflejo de corrientes culturales si no la consecuencia del cúmulo de prácticas que envuelven e intervienen en la multiplicidad de formas con que el paisaje se manifiesta". Traducción de la autora.
} 
Entre las investigaciones reunidas, los autores del volumen coordinado por Martin Lefebvre (2006) coinciden en que "in investigation landscape in film one is considering an object that amounts to much more than the mere spatial background that necessarily accompanies the depiction of actions and

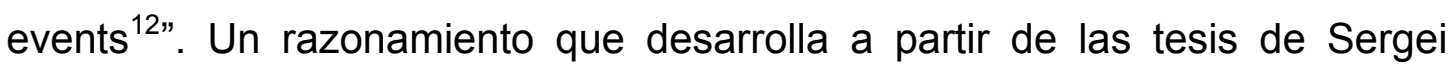
Eisenstein por las que equiparaba la importancia del paisaje para el cine mudo como lo fuere la música al cine sonoro, concluyendo que "landscape is a complex bearer of the possibilities of a plastic interpretation of emotions ${ }^{13}$. Este trabajo toma de las teorías de Lefebvre la vertiente del paisaje como "real perception of a space". Y parte del estadio inicial setting, donde se localiza la unidad mínima de significado de una película para establecer una división semiótica respecto a landscape, estadio que emerge al superar la función de unidad espacial y convertirse en entidad cultural y política como consecuencia de su interacción con el ser humano. Y, finalmente, de territory "space seen from the inside, a subjective and lived space ${ }^{14 "}$.

El paisaje es un fenómeno complejo "[...] composed of many elements and these elements interact to create our overall conception and reception. Like a map, the cinematic landscape is the imposition of order on the elements of landscape, collapsing the distinction between the found and the constructed $^{15 ",}$ afirman Graeme Harper y Jonathan Rayner quienes proponen abordar su análisis a partir de lo que llaman "realms of agreement". Uno de ellos tiene que ver con los postulados que sustentan la presencia del sujetocreador de imágenes, lo cual remite a la naturaleza subjetiva de las representaciones paisajísticas. La disparidad de procedencias e ideologías de estos sujetos abre múltiples vías en la definición de los distintos paisajes. Por ejemplo Nathan Richardson (2012) interpreta la cuestión 'nation' en

\footnotetext{
${ }^{12}$ Lefebvre, 2006: xii. "A la hora de analizar el paisaje en una película se considera que este llega a ser mucho más que el simple marco espacial que necesariamente acompaña el desarrollo de acciones y sucesos". Traducción de la autora.

${ }^{13}$ Eisentein Non Indifferent Nature, 1987: 355 a partir de Lefebvre, Ídem. "El paisaje es un continente complejo de posibilidades plásticas en cuanto a la interpretación de emociones". Traducción de la autora.

${ }^{14}$ Ídem: 53.

${ }^{15}$ Harper; Rayner, 2010: 13. "[...] compuestos de muchos elementos los cuales interactúan para crear nuestra concepción y recepción. Como un mapa, el paisaje cinematográfico es la imposición de orden en los elementos del paisaje, acabando con la distinción entre lo encontrado y lo construido". Traducción de la autora.
} 
relación a la construcción de un imaginario basado en el uso espacial desde que el régimen Franquista "overtly attempted to employ space as a key weapon in their blitzkrieg of Spanish identity ${ }^{16 " .}$. Unas tesis que remiten al valor simbólico del espacio que Ann Davies entiende como un continuo "process of becoming" a la hora de definir la entidad 'España', lo que implica rastrear en los productos culturales las huellas que "evokes a notion ${ }^{17 "}$ de ruralidad, en nuestro caso.

La asimilación de los discursos de estos autores plantea un marco teórico donde situar el estudio de las expresiones cinematográficas del entorno rural en todas sus facetas constitutivas. La perspectiva artística parte de la hipótesis sobre la función del paisajismo pictórico como escuela de la mirada siguiendo las teorías de Javier Maderuelo (2005) y de Alan Salvadó (2012) quien trata de determinar la incidencia de las diferentes culturas en el ejercicio paisajístico. El trabajo que aquí se presenta sitúa el origen contemporáneo de la ruralidad española en la literatura de viajes del siglo XIX, cuya mirada romántica definiría la vertiente exótica del imaginario rural nacional. Fundamentada, las más de las veces, por sesgos inherentes a la condición de extranjero de aquellos sujetos que se acercaban a lo desconocido. $Y$ en otras ocasiones sobre la oposición campo-ciudad. Una práctica que se pretende superar, como ya defendiese Boguslaw Galeski (1977) y actualmente Catherine Fowler y Gillian Helfield (2006), para centrarse en la especificidad del campo español como "repertorio común de referencias, [...] vasta gama de significados colectivos que sirven para facilitar la relación y la comprensión [...] Marco de referencias y de evidencias a partir de las cuales obran los seres humanos ${ }^{18}$ ". De hecho la cultura campesina se define en base al contacto con el entorno natural, el trabajo y la familia, elementos que conducen a la hipótesis por la que el entorno rural es un espacio de definición y reconocimiento de formación social, cuya conceptualización dependerá de una serie de condicionantes y agentes que variarán en el tiempo.

\footnotetext{
${ }^{16}$ Richardson, 2012: 33. "Explícitamente dirigida a utilizar el espacio como arma en el proyecto [de construcción] de una identidad española". Traducción de la autora.

${ }_{17}$ Davies, 2012: 1-20.

${ }^{18}$ Serna; Pons, 2005:11.
} 
En la historia reciente de España ha habido dos momentos de crisis en los que el entorno rural ha cobrado un relevante protagonismo a la hora de reconfigurar una identidad nacional. El primero se dio a raíz del desastre del 98 y el segundo tuvo lugar cuando la dictadura franquista se vio abocada a incorporarse a una economía moderna. En ambos periodos los núcleos comprometidos por encontrar el rumbo que debía emprender el país optaron por dotar de valor simbólico al entorno rural, situándolo en el centro de los discursos identitarios. En el período finisecular, regeneracionistas y autores de la Generación del 98 desarrollaron un sentimiento patriótico que, por ejemplo, llevó a Miguel de Unamuno, Azorín o Pío Baroja a recorrer y a escribir sobre la Castilla rural. De Unamuno describió con precisión los sentimientos que le produjeron las experiencias andariegas conjugando el conocimiento científico y el histórico con otros elementos culturales. El escritor aseguró encontrar en las gentes de estos lugares lo que llamó 'la casta íntima', de la cual extraía su intra-historia. El fenómeno de recurrir al interior del país dotaba de autenticidad la experiencia del viaje en un clima de desolación finisecular. Esta necesidad de realidad vincula a estos literatos con los alumnos del Instituto de Innovaciones y Experiencias Cinematográficas y demás hombres que, en un momento similar de reconstrucción del imaginario colectivo de mediados del siglo $\mathrm{XX}$, ahondaron en el cine en busca de nuevas fórmulas representativas. Un panorama del que el cine rural de los años cincuenta testimonia por ser este el resultado de las dinámicas de pensamiento y expresión que rigieron la vida española.

El cine español cuenta con innumerables antologías, historias y monográficos que evidencian la complejidad de esta materia, la cual, lejos de agotarse, urge ser abordada desde posicionamientos concretos. Metodológicamente el estudio propuesto parte de la necesidad de superar las prácticas historiográficas que han abordado la historia del cine o la historia del campo español a partir de la oposición de conceptos o las enumeraciones cronológicas. Y en cambio apostar por el análisis de los puntos de tensión, trayectos y transiciones acaecidos entre los agentes contextuales participantes. Esto supone poner en diálogo las fórmulas discursivas fílmicas con las estrategias políticas del régimen franquista, el estudio de los procesos 
de la industria cinematográfica y la tradición representativa del entorno rural en clave de construcción identitaria nacional.

Se propone un recorrido vertebrado en torno a dos ejes conceptuales: el arquetipo femenino y las prácticas del trabajo en el campo, que revelarán unas fórmulas estéticas y narrativas determinadas. La elección de estos dos ejes deriva de la asimilación de la tesis de Martin Lefebvre conjugadas con las de Henri Lefebvre sobre las diferentes formas que adopta la experiencia del paisaje "as perceived -the spatial practice, as conceived -representation of space, and lived -spaces of representation ${ }^{19}$ ". Y las de Graeme Harper y Jonathan Rayner cuando diferencian entre aquello construido y aquello encontrado. La experiencia del entorno rural en los casos de análisis se centrará principalmente en los estadios 'paisaje' como fenómeno que surge de la ordenación del espacio mirado y cuya especificidad en el contexto del cine rural termina por condicionar las tramas del drama rural. $Y$ 'territorio' por cuanto atiende a la casuística del espacio y de sus habitantes, en la línea en que Miguel de Unamuno incluía en sus textos ambos elementos, el paisanaje y el paisaje. Es decir, los usos espaciales que se sitúan en los estadios de una ruralidad vivida y encontrada, salvando la particularidad de cada una de los casos cinematográficos.

El análisis que aquí se desarrolla se centra en aquellas películas que contienen una mirada de los entornos rurales en el estadio de paisaje y de territorio al considerar que es en estos tratamientos donde emerge la incidencia del entorno rural en la vida de sus habitantes, como son los obstáculos laborales de la vida en el campo, y/o el condicionamiento del género femenino por los valores que rigen las comunidades rurales. Tal decisión posterga el análisis de aquellas películas de la vía del folclorepopular que hicieron un uso del espacio rural en el primero de los estadios definidos por Lefebvre, setting, puesto que no permite abordar dicha cuestión como entidad cultural. Una vía que, además, aborda el imaginario rural desde formas preconcebida cuyo significado trasciende los límites de este trabajo.

\footnotetext{
${ }^{19}$ Lefebvre, 1991: 38.
} 
En definitiva, la dimensión metafísica que surge del vínculo de la mujer a la tierra permitirá releer el uso del paisaje en el género del drama rural y determinar su significado acorde a las teorías de Nira Yuval-Davies (1997) sobre la doble función de las mujeres como simbólicas guardianes de la supuesta unidad de las comunidades imaginadas a la vez que generadoras de vida, constatación de su faceta 'natural'. Mientras que la representación fílmica de los avatares derivados del trabajo de la tierra dota de una dimensión social al cine rural que deriva en unas interpretaciones concretas en el contexto de transformación de la vida española de los años cincuenta.

Con el objetivo de extraer un conocimiento lo más extenso posible del significado de los usos cinematográficos del espacio rural español, se han consultado los textos de la prensa de la época sobre cine conservados en los depósitos de la Filmoteca Española, la Filmoteca de Catalunya y la biblioteca CulturArts IVAC. Y los expedientes administrativos custodiados en el Archivo General de la Administración. Esta historia cultural de las imágenes cinematográficas del entorno rural asimila de Lefebvre la hipótesis por la que el paisaje "manifest itself in the attempts by artists to translate this gaze into their work and by spectators to either interpret this translation or provide their own interpretative landscape gaze 20 . Es en este punto que las interpretaciones de la prensa cinematográfica adquieren especial relevancia al participar con sus juicios en el proceso de construcción del paisaje rural español el cual, desde una perspectiva política, se erigía en elemento clave para la configuración de un corpus referencial nacional.

En consecuencia este trabajo se estructura en seis capítulos de los cuales el primero se dedica a identificar ciertos aspectos políticos y culturales considerados fundamentales del marco espacial del la España de los años cincuenta. El segundo capítulo se centra en el estado de la cinematografía nacional considerando el intervencionismo del régimen franquista en relación a las vías comprometidas con el desarrollo del cine y de la vida española. El capítulo tercero profundiza en el fenómeno de la ruralidad desde los

\footnotetext{
${ }^{20}$ Lefebvre, 2006: 51.
} 
postulados del paisajismo, los estudios sociológicos y la tradición representativa en diferentes disciplinas artísticas. En el capítulo cuarto se establece el marco teórico sobre los usos cinematográficos del espacio y sus significados para ordenar los títulos de cine rural español de la década de los años cincuenta. Finalmente, los capítulos quinto y sexto se dedican al análisis de casos sobre el uso del espacio rural en el estadio de paisaje y territorio, respectivamente.

La traslación escrita de este proyecto ha dado como resultado una estructura que va del conocimiento de los diferentes contextos para el posterior entendimiento de casos concretos. Una configuración que creemos da cuenta de la constelación de trayectos y transiciones existentes entre ámbitos de actuación, obras y líneas de pensamiento con el objetivo de constatar el valor del cine rural español como "place and social practice that affirms the identity of the on-screen group, as that of the film audience, when it recognizes the images and characters ${ }^{21 "}$ como sostienen Fowler y Helfield.

El primer capítulo se centra en ciertos aspectos fundamentales de la situación política de la España de los años cincuenta a partir del cambio de estrategia interna del régimen franquista. El análisis de los agentes participantes y las facciones resultantes revelará unas tensiones con repercusión directa en el ámbito cultural y educativo dirigidas, principalmente, a armar una imagen concreta que ofrecer en el proyecto de reactivación internacional del régimen franquista. Motivo por el que se incluye una contextualización de la esfera cultural y política desde la que emergía la vida española.

El segundo capítulo aborda el estado de la cinematografía española de los años cincuenta en la paradoja franquista surgida a raíz del aperturismo diplomático en contraposición al estatismo interno. En otras palabras, la industria cinematográfica en relación a la intervención del régimen franquista

\footnotetext{
${ }^{21}$ Fowler; Helfield, 2006: 8. "El lugar y la práctica social que afirma la identidad del grupo representado en pantalla, así como de la audiencia cuando esta reconoce las imágenes y los personajes". Traducción de la autora.
} 
y con aquellas fórmulas y corrientes de pensamiento que abordaron el cine desde su especificidad. La figura de García Escudero como paradigma del compromiso desde las filas institucionales por un cine propio, el Neorrealismo italiano como referente estilístico, el IIEC como espacio, las primeras promociones del Instituto como agentes, y el encuentro cinematográfico de las Conversaciones de Salamanca como materialización de un nuevo sentir cuestionador.

En el tercer capítulo se trata la cuestión rural a partir de la genealogía del paisaje, como entidad cultural atendiendo a su origen en el arte para, a continuación, profundizar en las funciones y los usos del entorno rural a lo largo de la historia de España y en concreto de los años cincuenta. Una de las hipótesis se fundamenta en la idea que el ejercicio observacional de la ruralidad autóctona se desarrolló en relación a la conceptualización de la identidad nacional. Un hecho repetido en la historia reciente de nuestro país que evidencia las contradicciones de las políticas franquista que decían inspirar su ideario en el campo español pero, el cual, en la práctica se acercaba a su fin con el cada vez más acuciado éxodo rural. Del choque entre intenciones y realidad surge la producción cinematográfica rural de ese momento.

El cuarto capítulo se centra en el tratamiento cinematográfico de la cuestión rural en la producción de los años cincuenta. En primer lugar se establece el marco teórico que permitirá ordenar el corpus de cine rural. A continuación se aborda el proyecto de Ricardo Muñoz Suay como paradigma del uso espacial en el estadio de territorio y que enlaza con los preceptos de los literatos de la Generación del 98 y los postulados regeneracionistas que dotaban de valor simbólico a este espacio. $Y$ finalmente recalar en una panorámica sobre las diferentes fórmulas estéticas y temáticas que adoptaron los usos del espacio rural en todos sus estadios. Unos tratamientos que nutrieron el imaginario de los regionalismos españoles a partir de la fórmula del folklore o las derivas de la comedia y el musical o perpetuaron el género del drama rural siguiendo la tradición de acudir a la meseta castellana. 
El quinto capítulo es el análisis comparado de Condenados, Sierra maldita y Cañas y barro referentes del drama rural abordado a partir de la dimensión telúrica del arquetipo femenino. A nivel teórico esta elección se fundamenta en los estudios de Carmen Arocena y Nekane E. Zubiaur sobre la presencia de este arquetipo en la filmografía de Mur Oti. El tratamiento formal del uso del espacio rural se vincula a la tradición paisajística como génesis constitutiva. Y la depuración formal de cuestiones sociales con las lecturas de la prensa especializada cuya línea editorial se analiza en el contexto del proyecto diplomático franquista de reconstrucción identitaria.

El último capítulo comprende el análisis fílmico de La venganza como paradigma del tratamiento del entorno rural como territorio de conflicto social a partir de los episodios de trabajo en el campo. La acción del trabajo es definitoria del estamento campesino, sin embargo es prácticamente inexistente en el cine rural. El análisis comparado de La venganza con La guerra de Dios y Amanecer en Puerta Oscura revela unos tratamientos formales muy diferentes que discurren desde la función político-social al asentamiento de la moral nacional-católica.

En resumen, el objetivo de este trabajo doctoral es abordar los usos del espacio rural en el cine de la década de los años cincuenta y que constituye un imaginario leído en términos de construcción identitaria cuyo análisis permitirá entender "how, when and where the representation of countryside moves beyond universal aesthetic imitations to enter into an exchange with local struggles and concerns ${ }^{22 " .}$

\footnotetext{
${ }^{22}$ Richardson, 2012: 15. "Como, cuando y donde las representaciones del campo traspasan el ámbito estético para entrar en diálogo con las luchas y preocupaciones locales". Traducción de la autora.
} 


\section{Aspectos fundamentales de la política y la cultura española de los años 50}

\subsection{Sobre el contexto político}

La España de la década de los cincuenta era un país aún postrado tras el trauma de la Guerra Civil con intenciones de tomar el tren de la modernidad que lo resituase en el mapa internacional. En este período el proceso de consolidación del régimen franquista dejaría al descubierto las tensiones entre los diferentes grupos que constituían el Movimiento Nacional. En el empeño por "perder el lastre nacionalista y acercar el país al modelo capitalista neoliberal ${ }^{23 "}$ la España del régimen se adentraba en un lapso de inestabilidad, en palabras de Carmen Arocena ${ }^{24}$. Tradicionalmente la historiografía ha optado por abordar este período despojándolo de significación histórica debido a su ubicación entre la autarquía de la posguerra y el resurgimiento económico de la década de los sesenta. En este sentido, el calificativo de Arocena señala al preámbulo en que se gestó la segunda etapa del régimen franquista teniendo lugar, entre otros muchos acontecimientos, el choque entre viejos falangistas y jóvenes tecnócratas, un hecho político que revela un panorama de pugnas y contradicciones ideológicas trascendental para su análisis histórico.

El período 1945-1951 constituye el prolegómeno del declive del sistema autárquico concretado en 1957 con la remodelación del equipo de gobierno llamado a revitalizar el aparato franquista. Bajo el propósito de garantizar la supervivencia del régimen, la construcción de un imaginario cultural propio fue una prioridad en que intervinieron un nutrido número de intelectuales y dirigentes políticos que, fieles al Caudillo, entendieron la urgencia de unas políticas culturales acorde a la nueva etapa en que se adentraba la España de mediados de siglo.

\footnotetext{
${ }^{23}$ López, 1997: 224.

${ }^{24}$ Castro de Paz et alii, 2005: 70-127.
} 
El final de la Segunda Guerra Mundial había significado el aislamiento ${ }^{25}$ español a nivel internacional. El rechazo de entrada en la $\mathrm{ONU}^{26}$ y la retirada de embajadores extranjeros en 1946, la exclusión del European Recovery Program para la reconstrucción de la Europa occidental post II Guerra Mundial o el veto en la OTAN fueron las consecuencias del alineamiento del régimen franquista con los países del Eje durante el conflicto bélico. Unos acontecimientos que a nivel interno repercutieron en el estancamiento de la economía nacional debido, principalmente, a la falta de lazos comerciales para las exportaciones agrícolas, unido a una crisis industrial, la disminución de la renta y la escasa inversión, además de la inflación y consiguientes restricciones crediticias ${ }^{27}$.

Ya en 1942 la incertidumbre sobre el desenlace de la II Guerra Mundial alimentaba las tensiones entre las familias franquistas para las cuales "el sentido de la supervivencia política [de los sectores pronazis y más conservadores] les hacía desconfiar de la aventura bélica ${ }^{28 "}$. La caída de los regímenes nazi y fascista empujó a una recomposición del régimen franquista que, en el período de 1939 a 1945, experimentó tanto su consolidación como su más importante crisis en términos de consolidación interna y supervivencia externa. De este modo, el caudillo Francisco Franco emprendía una estrategia política para la supervivencia del régimen en la que la producción artístico-cultural asumiría una función propagandística. En este aspecto, la progresiva preeminencia de los sectores nacionalcatólicos sobre los falangistas resultaría decisiva.

\footnotetext{
${ }^{25}$ Se creó el Comité de 'No intervención' por el cual Francia y Gran Bretaña -junto a otros 27 países europeos- decidían no involucrarse en el conflicto español alegando la vía del apaciguamiento ante un panorama mundial de tensión prebélica.

${ }^{26}$ Entre los acuerdos de la Conferencia de Postdam, julio-agosto 1945, Estados Unidos, Reino Unido y la Unión Soviética dictaminaron que: "Los tres Gobiernos se sienten obligados, sin embargo, a especificar que por su parte ellos no apoyarían cualquier solicitud para ser miembro que pudiera hacer el actual Gobierno español, el cual, por haber sido establecido con ayuda de las potencias del Eje, no reúne, en razón de su origen, su naturaleza, su historial y su íntima asociación con los Estados agresores, las cualidades necesarias para justificar su admisión". Reproducido en Gubern, 1981: 56.

${ }^{27}$ Clavera et alii 1978: 138-146.

${ }^{28}$ Gubern, 1981: 53.
} 
A raíz del desembarco aliado en África del Norte en noviembre de 1942 el presidente norteamericano Roosevelt enviaba al régimen franquista una carta a modo de advertencia -recordatorio- de su declaración de 'no beligerancia' con fecha 12 de junio de 1940. La misiva obligaría a Franco a trabajar sus relaciones con Estados Unidos en detrimento de las amistades ítaloalemanas, lo cual iniciaba el declive de la influencia de Falange Española a favor de los sectores políticos católicos. Los primeros indicios de este traspaso de poder se encuentran en el cuarto gobierno franquista, en ejercicio del 18 de julio de 1945 al 18 de julio de 1951, en que la Secretaría General del Movimiento, bastión falangista, perdía la categoría ministerial y la habitual dotación económica. Igualmente la Subsecretaría de Educación Popular dejaba de estar controlada por Falange para ser dirigida por Ortiz Muñoz -uno de los responsables del viraje del régimen hacia el nacionalcatolicismo- y depender del Ministerio de Educación Nacional ocupado por José lbáñez Martín, también católico.

Iniciaba así la hegemonía del nacionalcatolicismo ratificada con la reforma del 18 de julio de 1951 que daba a luz al quinto equipo de gobierno franquista, de carácter democristiano y predispuesto a la diplomacia. Alberto Martín Artajo seguía al frente del Ministerio de Exteriores, ex presidente de Acción Católica Española y figura clave en la confirmación del apoyo católico al régimen franquista; el liberal democristiano Joaquín Ruiz-Giménez fue nombrado ministro de Educación; Manuel Arburúa ocupaba la cartera de Comercio; Gabriel Arias Salgado, falangista católico integrista, se ponía al frente del Ministerio de Información y Turismo y el almirante Carrero Blanco ascendía a ministro subsecretario de la Presidencia. El predominio del perfil católico de las nuevas incorporaciones ministeriales constató el desplazamiento falangista en el control de los órganos de gobierno franquistas. Un hecho que se confirmaba en la composición del sexto gobierno, de perfil tecnócrata, responsable de la entrada de España en el Fondo Monetario Internacional y del Banco Internacional de Reconstrucción y 
Desarrollo en 1958, así como de la puesta en marcha del Plan de Estabilización Económica ${ }^{29}$ de 1959.

\subsubsection{La conciencia social de vacío}

Los movimientos para la constitución de un nuevo equipo de gobierno franquista revelan el complejo sistema de tensiones internas del régimen en el período comprendido entre 1945 y 1959. El nuevo escenario internacional de posguerra obligaba a la reducción de los símbolos externos reconocibles del régimen dictatorial franquista ${ }^{30}$. La venia internacional propiciada por las recién estrenadas relaciones con los Estados Unidos, sumada al debilitamiento de la oposición externa y el desarme de la interna concluían en un "momento dorado del franquismo", en palabras de Jordi Gracia ${ }^{31}$. La conformidad en torno a la figura de Francisco Franco era indiscutible y la posibilidad de cualquier opción distinta inconcebible.

Desde la perspectiva social, en 1951 se recuperaba el índice de nivel de vida de 1936 aunque el dato se diese en una sociedad en que:

"Las calles [seguían] mal alumbradas, la miseria de las grandes barriadas de chabolas a las afueras de las ciudades [se vieron] engordadas por una emigración constante del campo a la ciudad; la presión propagandística y policial del aparato de poder franquista; la prepotencia de la administración y de la policía y el Ejército; y la mediocridad y grisura de casi todo ${ }^{32, "}$

Las oligarquías agrario-financieras tradicionales se topaban con la nueva burguesía comercial e industrial "que estaba acumulando su capital con la

\footnotetext{
${ }^{29}$ Un programa basado en la devaluación de la peseta, el control de cambios y el bloqueo de salarios que generó un alto nivel de desempleo, aliviado en parte por una emigración laboral masiva a Europa. Véase Díaz-Plaja, 1974.

${ }^{30}$ Gracia, J. 2004: 210. "Ya no debe alzarse el brazo y la voz al final de los pases de películas en los cines, y tampoco se saluda con el brazo en alto, aunque en las escuelas se canta el "Cara al sol" y se exhiben hasta el final del régimen los retratos de Franco y José Antonio a un lado y a otro de la cruz".

${ }^{31}$ Ídem: 202.

32 Ibídem.
} 
sobreexplotación de una clase obrera sindicalmente indefensa, con la especulación y al amparo de privilegios burocráticos de la Administración ${ }^{33 ” . ~}$

Ante tal panorama, quienes no habían optado por la resignación avivaban su crispación hacia el régimen. Habitualmente estos últimos eran jóvenes que habían visto partir a la guerra a sus mayores y que "cada vez más reparaban en lo mediocre, vacío, grotesco y absurdo del sistema ${ }^{34 " . ~ U n o s ~ n i n ̃ o s ~}$ pertenecientes a la clase media y a los que tanto el régimen como la Iglesia se esforzaban en armar ideológicamente persiguiendo el objetivo de "proletarización de la sociedad española 35 ". La Iglesia, alarmada por la creciente secularización de la clase obrera, encontraba en la clase media la destinataria idónea de sus enseñanzas. Con el transcurso de los años la "generación de los hermanos menores de los que hicieron la guerra 36 " se hizo adulta, consciente de la realidad coyuntural y la inexistencia de oportunidades individuales. Aunque su malestar no llegó a concretarse en un movimiento de disidencia política propiamente dicho si consiguió engendrar un rechazo moral e intelectual que se manifestó por ejemplo, de manera puntual, en las revueltas universitarias de 1956. En resumen, esta generación dio lugar a un cuestionamiento surgido en el seno social franquista procedente de la clase media burguesa aunque ubicada en el contexto institucional falangista, principalmente el Sindicato Estudiantil Universitario ${ }^{37}$, que jugaría un papel importante en el proyecto integrista de Ruiz-Giménez, como veremos.

"Las grandes figuras de nuestra juventud eran todas de barro"38". Esta sentencia sintetiza la percepción de una generación que cada vez más desconfiaba de las bondades de un régimen anclado en los discursos

\footnotetext{
${ }^{33}$ Gubern, 1981: 116.

${ }^{34}$ Gracia, 2004: 203.

${ }^{35}$ La fijación del franquismo en la clase media no es exclusiva del régimen español, pero si importante hasta el extremo de materializarse en la celebración de las Semanas Sociales de España durante la década de los cincuenta o el Congreso del Instituto Internacional de Clases Medias. Ídem: 206.

${ }^{36}$ Denominación dada por J. F. Marsal en Pensar bajo el franquismo. Intelectuales y política en la generación de los años cincuenta, 1979. Y también en referencia a los niños protagonistas del libro de Josefina R. Aldecoa Los niños de la guerra, 1983, en que la autora profundiza en el trauma vivido por aquellos que compartieron la circunstancia de haber nacido en la España del 36.

${ }^{37}$ Fundado por José Antonio Primo de Rivera durante la Segunda República con el objetivo de contrarrestar la influencia de la Federación Universitaria Escolar.

${ }^{38}$ Benet, 1987: 91.
} 
coreados durante la victoria del 18 de julio del 36 y que, más que una garantía de futuro, encorsetaba el desarrollo connatural de la sociedad española. La toma de conciencia de la situación nacional llevó a la politización de una parte importante de la sociedad de los núcleos de Madrid y Barcelona y otras capitales españolas. Un hecho que constataría el fracaso del "régimen en la socialización de los jóvenes" 39 " y también de la inminente expiración de sus postulados. En definitiva, estos núcleos de conciencia rechazaban el sistema autoritario franquista que no dejaba margen al desarrollo de otras inquietudes, dejando en un segundo plano el cuestionamiento de la figura del Caudillo. Un núcleo de conciencia se gestó en torno al Instituto de Investigaciones y Experiencias Cinematográficas cuyos participantes se sirvieron del cine para concretar un nuevo sentir estrechamente relacionado con la realidad social de la España de mediados del siglo XX, como se analizará en posteriormente.

\subsubsection{Tensiones en el estancamiento del falangismo}

Las vicisitudes de los nuevos tiempos anunciaban la obsolescencia de los falangistas del 18 de julio. Mientras el inmovilismo del falangismo histórico hacia fracasar el proyecto neototalitario de José Luis de Arrese, optando por sobreponerse a "los cambios aparentes, [en un] juego permanente entre las diversas tendencias y sectores que le apoyaban, siempre con el objetivo central de sostener el poder personal y autoritario del caudillo como garante del mantenimiento de un status quo favorable a los intereses dominantes ${ }^{40 "}$. Ante la crisis del núcleo falangista, la cual afectaba directamente al desarrollo de las políticas del régimen, surgieron distintas propuestas desde el seno franquista.

Es representativo el caso de Joaquín Ruiz-Giménez. Ministro de Educación Nacional entre julio de 1951 y febrero de 1956, abanderó una

\footnotetext{
${ }^{39}$ Gracia, 2004: 210.

${ }^{40}$ Gubern et alii, 2009: 243.
} 
propuesta de integración con el propósito de aglutinar a los sectores más dialogantes para "cambiar el talante, el discurso [de una] dictadura muy lastrada por la dialéctica vencedores-vencidos, intentando así un gesto de reconciliación y de superación de las heridas aún tan recientes ${ }^{41}$ ". En definitiva se trataba de mitigar el trauma bélico con el fin de asegurar la supervivencia del régimen. La inicial lectura aperturista de la estrategia de Ruiz-Giménez en ningún momento perseguía una ruptura con la base franquista, es más coincidía en legitimar la figura del Caudillo, otorgándole el estatus de héroe vitalicio. En torno a Ruiz-Giménez se congregaron:

"Católicos abiertos, con preocupación social, mayoritariamente propagandistas [...] pero también falangistas otrora caracterizados por criticar al régimen por su entreguismo a la Iglesia, y que tenían un tono mucho más abierto y una formación más 'liberal", también se unieron los falangistas más sensibles respecto a la coyuntura social y el SEU dirigido entonces por Jorge Jordana. Una llamada que pretendía "conseguir un mayor consenso y apoyo social por vías que no fueran la mera represión y con el deseo de incorporar, fagocitar [...], una parte de la tradición liberal e izquierdista española ${ }^{42 " .}$

Pero sería la propia naturaleza del proyecto la que lo haría fracasar debido, principalmente, a que no había surgido del entorno más próximo a Franco. Un hecho que generaba una incipiente hostilidad de los sectores más retrógrados del ejército, miembros de la Secretaría General del Movimiento y demás ministros "cercanos a la tradición anti-intelectual y paramilitar de la Falange, que rechazaban cualquier intento de apertura o de diálogo ${ }^{43}$ " por miedo a ser desplazados del núcleo de poder.

Ante el inviable consenso de la propuesta de Ruiz-Giménez se compuso el grupo conocido como la Tercera Fuerza ${ }^{44}$ alrededor de Rafael Calvo Serer, miembro destacado del Opus Dei y del CSIC, y que contaba con la presencia

\footnotetext{
${ }^{41}$ Gracia, 2004: 212.

42 Ibídem.

43 ídem: 214.

${ }^{44}$ La denominación 'Tercera Fuerza' se debe a la oposición radical de estos hombres hacia los falangistas tradicionales que consideraban "desviación fascista de la esencia española tradicional", puesto que su posicionamiento ideológico se encontraba alejado tanto del falangismo como de ideas de monarquía liberales. A partir de los razonamientos de Gracia, Ibídem.
} 
del ex ministro de Educación Nacional, Ibáñez Martín, ahora presidente honorífico, y Florentino Pérez Embid. Calvo Serer se erigió en acérrimo defensor del ideario del 18 de julio y de la obra de Menéndez Pelayo en su lectura del catolicismo nacionalista al considerarlo propio de la esencia española. Además, este nuevo grupo tomaba como referente la figura de Don Juan de Borbón, proponiendo una monarquía no parlamentaria como solución a la continuidad del régimen tras la muerte del caudillo. Ingredientes para una vía que se aferraba a la "tradición política, religiosa y social, excluyendo a todos los que habían intentado destruir, cambiar o modificar esa realidad eterna que sería la España de Menéndez Pelayo ${ }^{45 " . ~ D e ~ a h i ́ ~ l a ~}$ definición de 'excluyentes' de la conocida como Tercera Fuerza en oposición directa al grupo integrista de Ruiz-Giménez quien, por su parte, también revisitaba referentes pasados interesados en la cuestión nacional, y en concreto la obra de Miguel de Unamuno y José Ortega y Gasset.

\subsubsection{Diplomacia hispano-norteamericana. Estados Unidos como única opción}

La reafirmación del posicionamiento neutral de España en octubre de 1943 en el contexto de la II Guerra Mundial sumada al viraje en la estrategia diplomática del aparato interno franquista, empezaba a vislumbrar cierta necesidad de acercamiento al futuro aliado americano. Román Gubern habla de un "americanismo oficial en la política informativa [no] reñido con un antiamericanismo beligerante por parte de la Falange [,] de la censura oficial $^{46 "}$. Una contradicción que teniendo en cuenta el desarrollo de los acontecimientos bélicos se resolvió a favor del diálogo con los Estados Unidos, en detrimento de la opinión y poder de los miembros de Falange ${ }^{47}$.

\footnotetext{
${ }^{45}$ Ibídem.

${ }^{46}$ Gubern, 1981: 56.

${ }^{47}$ El mapa internacional post II Guerra Mundial obligaba al régimen franquista a renegar manifiestamente de sus antiguos aliados, motivando el bloqueo de los bienes del Eje el 8 de mayo de 1945 y la derogación de la obligatoriedad del saludo fascista el 11 de septiembre de ese año.
} 
En 1946 la presión internacional sobre el régimen franquista alcanzó sus cuotas más altas con la negación de entrada en la Organización de Naciones Unidas por parte de Estados Unidos, Gran Bretaña y Francia. El político José María de Areilza en Embajadores sobre España ${ }^{48}$ describe esta circunstancia de rechazo internacional:

"Los Gobiernos de Francia, Reino Unido y Estados Unidos de América han cambiado impresiones respecto al actual Gobierno español y las relaciones de aquéllos con este régimen. Se acuerda que en tanto el general Franco siga gobernando en España, el pueblo español no puede esperar una plena cordial asociación con aquellas naciones del mundo que, mediante su esfuerzo común, han derrotado al nazismo alemán y al fascismo italiano, los cuales ayudaron al actual régimen español a alcanzar el poder y sirvieron de patrón a tal régimen".

Y en referencia al inmovilismo internacional ante la coyuntura interna española prosigue Areilza:

"No se tiene la intención de intervenir en los asuntos internos de España. El propio pueblo español tiene, a la larga, que buscarse su destino. A pesar de las medidas represivas del actual régimen contra los esfuerzos ordenados del pueblo español para organizar y dar expresión a sus aspiraciones políticas, los tres Gobiernos confían en que el pueblo español no será sometido de nuevo a los horrores y enconos de la lucha civil".

"Por el contrario, se tiene la esperanza de que los españoles patrióticos y de mentalidad liberal de más relieve, puedan pronto encontrar los medios para lograr la retirada pacífica del general Franco, la abolición de la Falange y el establecimiento de un Gobierno interino bajo el cual pueda el pueblo español tener la ocasión de determinar libremente el tipo de Gobierno que desee y elegir sus dirigentes. La amnistía política, el regreso de españoles exiliados, la libertad de reunión y asociación política y la adopción de medidas para celebrar elecciones públicas libres, son esenciales".

${ }^{48}$ Areilza, 1947: 211. 
Ante la contundencia de la opinión internacional el gobierno franquista respondió con una serie de medidas que buscaban rebajar las tensiones internas de poder y, con ello, dar una imagen exterior menos opresora. En primer lugar se intentó justificar la necesidad de una censura atendiendo al contexto extraordinario de posguerra. El preámbulo de la Orden del Ministerio de Educación Nacional de 26 de marzo de 1946 dictaminaba:

"Ni durante la guerra de liberación de España ni en los meses inmediatamente posteriores a ella hubiera sido posible, por razones de elemental prudencia política, prescindir de una medida, de carácter excepcional, pero indispensable como era en aquellos momentos la censura de prensa".

"El estallido de la II Guerra Mundial y la necesidad de mantener a toda costa la neutralidad española, vinieron a añadir nuevas razones [...]. Quizá no haya llegado aún el momento de prescindir totalmente de la censura, pero sí de iniciar una serie de medidas que [...] permitan a los periódicos una mayor amplitud de movimientos y sirvan, al mismo tiempo, de indispensable experiencia previa para disposiciones ulteriores".

La renovación de la imagen exterior iba a permitir, entre otros, la celebración en julio de 1945 del Fuero de los Españoles o el indulto el 9 de octubre de ese año por delitos de rebelión militar cometidos hasta el 1 de abril de 1939. Pero las exiguas medidas de apertura del régimen franquista no fueron suficiente y el 9 de febrero de 1946 se hacía oficial la negación de entrada en la ONU, aunque el gobierno franquista no desistía en su empeño y aprobó la Ley de Sucesión de 6 de julio de 1947 que supondría una mínima transformación de la definición del Estado Nacionalsindicalista, dejando atrás la esencia totalitaria del alzamiento militar y posterior régimen dictatorial. En el artículo 1 de dicha ley se lee:

“España, como unidad política, es un Estado católico, social y representativo, que de acuerdo con su tradición, se declara constituido en Reino".

El discurso del presidente norteamericano Harry S. Truman, el 12 de marzo de 1947, dibujaba el primer trazo de un nuevo escenario mundial 
atemorizado por el fantasma del comunismo donde Estados Unidos planeaba un bloque internacional frente a la Unión Soviética de Stalin, entre los socios se preveía la España anticomunista de Franco. Así, la llegada de la década de los cincuenta confirmaba la estrategia franquista de acercamiento diplomático a los EUA, una acción que beneficiaría significativamente la imagen del régimen franquista. El nuevo aliado americano aprobaba un crédito de 62,5 millones de dólares en ayudas a España y la votación a favor en la Asamblea de Naciones Unidas del regreso de sus embajadores a Madrid en 1950. En enero del año siguiente la VI Flota de los Estados Unidos atracaba en el puerto de Barcelona y en febrero los embajadores americanos volvían a sus puestos con el extra de un crédito del Export-Import Bank por valor de 60 millones de dólares que se sumaba al crédito de 1949 de la Chase National Bank de 25 millones de dólares para la compra de productos agrícolas, materias primas y equipo industrial. El fin del bloqueo antifranquista también se apreciaba en el creciente flujo de turistas que empezaba a llegar a la Península. Un fenómeno que entraría en conflicto en muchas ocasiones con la moral del nacionalcatolicismo y que contribuiría a definir una de las muchas paradojas de estos años, cuya repercusión se empezaría a notar en la producción artístico-cultural.

En la década de los cincuenta la relación con los Estados Unidos iba a suponer "la reafirmación del régimen como realidad internacional ${ }^{49}$ ". El gobierno franquista focalizó su táctica aperturista a tender lazos con EUA, el cual a los ojos de la burguesía franquista 'liberal' representaba el sueño de aquella sociedad moderna y capitalista, cuyo mejor símbolo era el arte abstracto fundamentado en la voluntad individual del autor. Por su parte el compañero americano aprovecharía la oportunidad para relacionarse con un país, declarado anticomunista en el escenario previo a la Guerra Fría, estratégico geográficamente y con potencial para la consolidación de un mercado interior. Desde la perspectiva norteamericana la reorientación del nuevo panorama político ofrecía cobijo a un sistema político "relativamente inconveniente e impresentable pero eficaz ante cualquier rebrote comunista

\footnotetext{
${ }^{49}$ Marzo, 2010: 95.
} 
en el flanco sur de la Europa occidental ${ }^{50 " . ~ E n ~ d e f i n i t i v a, ~ u n a ~ a l i a n z a ~}$ diplomática que comportó la admisión de España en la FAO, 1950; la OMS y la UIT, 1951; la UNESCO, 1952 y en la ONU, 1955. Un buen entendimiento reafirmado con la llegada a la presidencia de los EUA del republicano Dwight D. Eisenhower en enero de 1953.

\subsection{La educación y la cultura}

\subsubsection{Las políticas educativas de Joaquín Ruiz- Giménez}

Ruiz-Giménez trazó una línea política que, influenciada por el pensamiento de Ortega y Gasset, situaba en su horizonte a Europa. Para ello se rodeó de falangistas históricos de perfil intelectual como Pedro Laín Entralgo, rector de la Universidad de Madrid, y Antonio Tovar, rector de la Universidad Pontificia de Salamanca ${ }^{51}$ y figura importante en el contexto de las Conversaciones de Salamanca que trataremos más adelante. Desde su llegada a la cartera de Educación Ruiz-Giménez tuvo como objetivo mejorar la situación de la enseñanza hasta la fecha marginada de las políticas económicas del régimen, como demuestra la carencia de instalaciones, equipamiento y los bajos sueldos de los profesores ${ }^{52}$. Entre las acciones, en febrero de 1953 se reformó el bachillerato de 1938 con el objetivo que el Estado recuperase el poder de gestión entonces en manos de la Iglesia católica ${ }^{53}$, lo cual supuso arduas negociaciones con el Vaticano aferrado a sus prerrogativas ${ }^{54}$

\footnotetext{
${ }^{50}$ Gubern et alii, 2009: 239.

51 Además de los directores generales Joaquín Pérez Villanueva de Enseñanzas Universitarias, y Carlos $\mathrm{M}^{\mathrm{a}}$ Rodríguez de Valcárcel de Enseñanzas Técnicas y José $\mathrm{M}^{\mathrm{a}}$ Sánchez Miniaín de Enseñanzas Medias. Y Ángel Antonio Lago Carballo secretario particular de Ruiz-Giménez.

${ }^{52}$ El informe para paliar la situación del $30 \%$ de niños en edad escolar sin escuela donde acudir contemplaba, en palabras del propio ministro, por construir 1000 edificios anuales. Tusell, J. 1984: 372.

${ }^{53} \mathrm{La}$ correspondencia del régimen franquista al apoyo legitimador de la Iglesia católica durante el golpe de Estado en forma de Ley de Ordenación de la Universidad Española de 29 de julio de 1943 por la que se incluía el dogma y la moral católica en los planes de enseñanza universitaria.

${ }^{54}$ Entre ellas la surgida a raíz del cuestionamiento de Laín Entralgo de la asignatura obligatoria Formación Religiosa en el currículum universitario.
} 
mayestáticas, recién renovadas con la firma del Concordato. Finalmente, la constatación de una nueva conciencia entre las filas franquistas sobre las cuestiones educativas se concretó con la celebración de la Asamblea Nacional de Universidades y del Congreso Nacional de Estudiantes en 1953.

Sería concretamente en el ámbito universitario donde Ruiz-Giménez desarrollaría sus políticas aperturistas convirtiendo la institución educativa en "islas de libertad" 55 " tras derogar el régimen discrecional del nombramiento de tribunales y replantear la recuperación de la obra de Miguel de Unamuno o del entonces exiliado José Ortega y Gasset. Unas políticas tachadas de agitadoras desde los sectores falangistas más inmovilistas que insistían en la alarmante "desviación ideológica de la juventud" ${ }^{56 " ~ b a s a ́ n d o s e ~ e n ~ l o s ~ s u c e s o s ~}$ de las revueltas universitarias de febrero de 1956 precedidas, además, por las manifestaciones en el entierro de Ortega y Gasset en octubre de 1955. No obstante, atendiendo al perfil activo de ciertos sectores del núcleo falangista, $\mathrm{y}$, como se ha descrito anteriormente, las generaciones más jóvenes manifestaban su malestar aprovechando los márgenes de lo decible abiertos por las políticas de Ruiz-Giménez, Antonio Tovar o Jorge Jordana en su etapa al frente del SEU.

\subsubsection{Las derivas del intervencionismo artístico- cultural franquista}

"If anything characterized the Francoist regime throughout its history it would doubtless be its vision of Spain as a uniform and culturally homogeneous nation, and its tendency to label as separatist any sign of discrepancy with its model of a centralist state ${ }^{57 " .}$

\footnotetext{
${ }^{55}$ Gracia, 2004: 211.

${ }^{56}$ Ibídem.

${ }^{57}$ Reproducido en Richardson, 2012: 5. "Si algo caracterizó al régimen franquista a lo largo de su historia sería, sin duda, su visión uniforme de España, culturalmente homogénea, y su tendencia a etiquetar de separatista cualquier otro signo de discrepancia con su modelo de estado centralista". Traducción de la autora.
} 
La Guerra Civil española y la II Guerra Mundial tuvieron sus respectivos trasuntos en el panorama artístico-cultural. Las vanguardias habían quedado en parte desarticuladas. De este modo, la persecución política de los republicanos y la depuración de obras de arte y demás producción cultural moderna y vanguardista dejaba vía libre al régimen franquista para liderar el proyecto de definición de la 'razón nacional' en el arte español.

El régimen emprendió el control de la producción artístico-cultural a través de un entramado de instituciones encabezado desde el Ministerio de Cultura Nacional, dirigido en ese momento por Ruiz-Giménez. El ministro, que había sido director del Instituto de Cultura Hispánica entre 1946 y 1948, articuló el discurso inaugural de la I Bienal Hispanoamericana de Arte en 1951 en torno al protagonismo del Estado como mecenas. Función dirigida a encubrir el centralismo político ahora expandido al terreno cultural y guiado por el afán de emular al mecenazgo de las monarquías hispánicas pasadas. En ese mismo discurso el ministro se afanaba en recordar el compromiso moral de los artistas de la vanguardia con su nación. En otros términos, promulgaba un nacionalismo español reafirmado en la producción artística del país sin perder el contacto directo con el resto de prácticas artísticas internacionales.

La urgencia diplomática por disponer de una imagen de liberalidad propició el convencimiento sobre "la inocuidad de la práctica artística como forma de contestación política, y de ello, se iba a derivar la total falta de escrúpulos en el uso de obras de arte producidas por artistas (algunos) que, en privado, no manifestaban ningún apego por el franquismo", enlazando así con la "gran tradición española de separar al artista del ciudadano que hay detrás ${ }^{58 ” . ~ E s t e ~}$ pensamiento falangista derivó en el ensalzamiento de la individualidad del artista español, rescatando la figura de Velázquez, Goya o Picasso ${ }^{59}$.

\footnotetext{
${ }^{58}$ Marzo, 2010: 53.

${ }^{59}$ Otro caso paradigmático fue el de Jorge de Otieza. Máximo exponente de la Escuela Vasca de Escultura y declarado antifranquista, acompañó a González Robles en la Bienal de Sao Paulo de 1957, donde se presentó como ejemplo de artista español vinculado de algún modo con las políticas culturales del franquismo.
} 
El enaltecimiento de la individualidad del artista respondía al arquetipo del héroe solitario alabado por la élite franquista. Una idea basada, en primera instancia, en la contestación a los ismos europeos, de carácter colectivo, anticristiano y carentes de preocupaciones morales. De entre los movimientos artísticos europeos de mediados del siglo XX, el Surrealismo era el más politizado debido a su adhesión a la revolución marxista y la vinculación de algunos de sus miembros más destacados al Partido Comunista francés. $Y$ es que la construcción del arquetipo del artista individual desde los preceptos del héroe solitario debía ser el garante de "los eternos valores nacionales [sin dejar de estar] sujeto a la dinámica internacional propia de cada momento ${ }^{60 "}$. No obstante el acérrimo empeño del aparato franquista por evitar influjos políticos y la contaminación de manifestaciones culturales foráneas incurría en una de las muchas paradojas del régimen en estos años, como fue la estrategia de una política exterior aperturista manteniendo unos postulados internos de inmovilismo. Una circunstancia que Marzo define como la 'cuestión greenberiana' por la que la cultura era entendida por la dictadura de manera liberal, siempre y cuando fuese en términos de relaciones internacionales y no de contexto político interno ${ }^{61}$. "El panorama cultural de España era muy grave en estos años, tanto en el campo de la enseñanza, como en la producción cultural y en la política de información ${ }^{62}$ ", sentencia Gubern. Sin embargo, y teniendo presente la casuística de un régimen militar como el franquista, en el campo de las artes plásticas existió cierto margen para la experimentación debido a su contenido político más ambiguo en relación a la literatura, la fotografía o el cine.

La producción plástica propició el surgimiento de nuevas actitudes y modos de expresión que enlazaban con la vanguardia. Por un lado destaca la línea surrealista del grupo Dau al Set, 1948, y Antoni Tàpies, el grupo El Paso, 1957, y Equipo 57 que se sumarían al Informalismo europeo. Y por otro los pintores que, como José Ortega y Ricardo Zamorano, se decantaban por

\footnotetext{
${ }^{60}$ Marzo, 2010: 57.

61 Ibídem.

${ }^{62}$ Gubern, 1981: 118.
} 
una pintura de temática social comprometida. Una reactivación inicial de los influjos artísticos que con la restitución de las relaciones diplomáticas permitió importar las narrativas y fórmulas norteamericanas. $Y$, aunque en cantidad y condiciones muy diferentes, las del realismo italiano en el ámbito literario y cinematográfico, principalmente, como posteriormente se analizará.

En el terreno cultural se distinguen un conjunto de actitudes, gestos y obras contestatarias que, sin un plan coordinado y homogéneo -como tampoco lo sería el proyecto ministerial de Ruiz-Giménez- revelaron cierta inflexión en el pensamiento de la sociedad española del momento. En primer lugar, la crisis interna del aparato franquista dibujaba un nuevo contexto en que un núcleo ultraconservador de falangistas se enfrentaba a la vía planteada por Ruiz-Giménez, la cual, desde una perspectiva historiográfica, constataba la viabilidad de actitudes contestatarias ${ }^{63}$-no tanto política como intelectual y moralmente- en relación a la línea única de pensamiento y acción del régimen franquista. $Y$ todo ello en una coyuntura internacional de reactivación diplomática que, en un grado importante, contribuía a la distensión de los márgenes de lo decible. Por todo ello, Enrique Monterde opina que sí puede hablarse de disidencia:

"Más o menos tolerada y reprimida alternativamente, que tanto podrá significar la aproximación a una estética realista como la apertura a determinadas tendencias dominantes en el contexto internacional, significando un cambio fundamental respecto al monolitismo y la cerrazón de los años $40^{64 "}$.

Tal fue el caso de la literatura de los años 50 en que numerosos autores compartieron un mismo espíritu crítico "contra la vacuidad retórica y embellecedora de la cultura oficial ${ }^{65}$. Un fenómeno que, más allá de ser el resultado connatural a una emergencia generacional, en palabras de Torrente

\footnotetext{
${ }^{63}$ Nuevas actitudes como las surgidas en el ámbito teatral a partir del manifiesto Teatro de Agitación Social firmado por Alfonso Sastre y Manuel de Quinto, entre otros. O la repercusión de la obra de Antonio Buero Vallejo Historia de una escalera, 1950, Escuadra hacia la muerte de Alfonso Sastre, 1953 o Los inocentes de la Moncloa de Rodríguez Méndez, 1961, entre los enumerados por Gubern et alii, 2009: 242.

64 Ídem: 241.

${ }^{65}$ Gubern, 1981: 120.
} 
Ballester se trataba del "desplazamiento definitivo de nuestro centro de gravitación literario, desde la emigración, a la península ${ }^{66 " . ~ N o ~ o b s t a n t e, ~ l o s ~}$ análisis históricos de dicha coyuntura revelan ciertos dilemas a la hora de abordar la producción de estos autores que materializaron su denuncia política a través de la descripción de la realidad social de su tiempo. Así lo demuestra Eugenio de Nora cuando argumenta que el aglutinador de toda la producción disidente no respondía al imperativo de realismo social que Torrente Ballester asociaba con la influencia del realismo socialista soviético, ni tampoco a la literatura vehementemente comprometida.

Más allá de los debates en torno a la filiación de los referentes externos sobre los que se construyó la obra de los autores nacionales, en la producción cultural de los cincuenta, a diferencia de la década anterior, existió un verdadero interés crítico por la coyuntura social española.

\subsubsection{Referentes para un arte propio}

Cierto número de entidades y nombres propios que, sin abandonar la lealtad al régimen, contribuyeron a la existencia de una producción cultural la cual, desde una perspectiva historiográfica, encerraba en sí unas estrategias políticas muy concretas, dado el contexto diplomático del período. Dependiendo del Ministerio de Asuntos Exteriores en 1940 se había fundado el Consejo de la Hispanidad con el objetivo de difundir el arte español en clave de promoción nacional. El Consejo era un organismo constituido por destacados intelectuales como Manuel Aznar, Ramón Menéndez Pidal o Manuel García, además de Antonio Tovar y Pedro Laín Entralgo. La trayectoria de esta institución duró apenas cinco años debido al clima posterior a la II Guerra Mundial que propiciaría en septiembre de 1942 la destitución de Ramón Serrano Suñer de la cartera de Exteriores. Un hecho que marcó el declive del organismo reconvertido en el Instituto de Cultura Hispánica, ICH, el 31 de diciembre de 1945. La nueva entidad, vinculada a

\footnotetext{
${ }^{66}$ Torrente Ballester, 1965: 523.
} 
grupos católicos próximos al régimen, seguía dependiendo del Ministerio de Asuntos Exteriores a través de la Dirección General de Relaciones Culturales.

El ICH controló durante los años cuarenta la política artístico-cultural del régimen franquista con el principal objetivo de mantener la tradicional propaganda hispanófila en América del Sur, vía mediante la cual se pretendía alcanzar al nuevo socio americano. La labor del ICH se materializó en las Bienales Hispanoamericanas de Arte, principal plataforma cultural del régimen ${ }^{67}$; la edición de Cuadernos Hispanoamericanos y la constitución del Instituto de Cooperación Hispanoamericana. La influencia de la institución fue tal que "se conformó como un observatorio del poder para monitorizar aquellos comportamientos culturales que pudieran ser utilizados en beneficio de la imagen del franquismo ${ }^{68 " . ~ E I ~ I C H ~ t a m b i e ́ n ~ g e s t o ́ ~ u n a ~ " r e d ~ d e ~ i n t e r e s e s ~}$ que permitió el surgimiento de una vanguardia a la sombra de determinadas dinámicas nacionales e internacionales" buscando la redefinición del arte español. Al frente del mismo y de los diferentes órganos dependientes se situó una generación "de alto standing, nacionalista, católica, ferozmente anticomunista pero no por ello reñida con un aparato estético moderno ${ }^{69}$ ".

El segundo agente fue Eugeni d'Ors (1881-1954) quién contribuyó significativamente a la definición de una vanguardia española desde los postulados del Noucentisme.

"[D’Ors] dominó la escena artística de los primeros años de la dictadura. Representaba la paradoja en que se movía el contexto creativo llamado a saciar las necesidades de los círculos bien pensantes franquistas -sobre todo los de tradición liberal- y el proceso de evolución que sufrieron en la adquisición de una consciencia de la importancia del elemento cultural ${ }^{70}$.

\footnotetext{
${ }^{67}$ Por cuanto jugaron un doble papel como difusoras del arte español en el exterior, a la vez que contribuyeron a la normalización de la situación cultural en el interior del país. Y es que ante el convencimiento de la aparente sinergia entre Estado y arte muchos artistas prestaron sus obras en los encuentros artísticos, a pesar de las llamadas al boicot de los exiliados.

${ }^{68}$ Marzo, 2010: 41.

69 Ídem: 46.

70 Ídem: 31.
} 
Desde sus preceptos estéticos barrocofascistas, d'Ors defendía la necesaria reconexión con la tradición estética de preguerra que asegurase la supervivencia del régimen. Surgía así su visión del estilo del barroco ${ }^{71}$ como "categoría que en determinadas circunstancias puede aparecer en diferentes épocas", prevaleciendo en el barroco español "el criterio de austeridad sobre

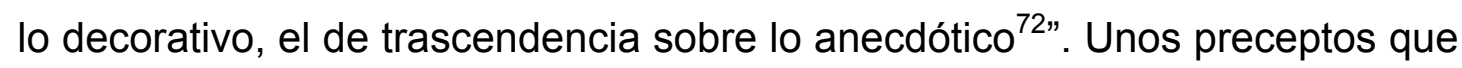
d'Ors veía compendiados en el incipiente estilo informalista, de ahí que Díaz Sánchez considere "la huella orsiana [...] esencial en la génesis del relato informalista ${ }^{73 " . ~ D e s d e ~ e l ~ N o u c e n t i s m e, ~ e l ~ i n t e l e c t u a l ~ y ~ e n s a y i s t a ~ c a t a l a ́ n, ~}$ como también hiciesen los literatos de la Generación del 98, interpretó las cuestiones de identidad nacional materializadas en el arte y la cultura, cuyas manifestaciones constituirían los vasos comunicantes entre la España de 1950 con la tradición nacional propia. De este modo, "la vanguardia española de posguerra se formuló en una dictadura que conformó las aspiraciones artísticas de la misma manera que la identidad nacional", en palabras d'Ors, "lo que no proviene de la tradición es plagio ${ }^{74 " . ~}$

D’Ors concretó sus teorías estéticas en 1941 con la fundación de la Academia Breve de Crítica de Arte, $A B C A$, desde la que reivindicaba la política, la iglesia y la burguesía como "los nuevos paladines del renacer del arte español perdido desde hacia tiempo -desde Goya exactamente- en tierras infértiles ${ }^{75}$ ". Con tal fin se contempló una nómina de autores entre los que se encontraban Nonell, Gargallo, Torres García, María Blanchard, Barradas, els Noucentistes, Zabaleta, Eduardo Vicente, la Escuela de Madrid, los Indalianos o Benjamín Palencia, además de Dalí y Miró. Unos referentes para la fundamentación de la nueva tradición artística española sobre la tríada "el espíritu, la unidad y lo eterno ${ }^{76 " . ~ P o s t e r i o r m e n t e, ~ e n ~ l a ~ m i s m a ~ l i ́ n e a ~}$ d'Ors arropó desde el Salón de los Once a una nueva generación de artistas, entre ellos Antoni Tàpies, Antonio Saura, Millares, Cuixart o Jorge de Oteiza

\footnotetext{
${ }^{71}$ Disertaciones que formaban parte del glosario que Eugeni d'Ors publicó periódicamente en prensa catalana y que, finalmente, compendió en el monográfico Lo barroco, 1935.

${ }^{72}$ Marzo, 2010: 34.

${ }^{73}$ Díaz Sánchez, 2013: 58.

${ }_{75}^{74}$ Reproducido en Marzo, 2010: 36.

75 ídem: 34.

${ }^{76}$ Ídem: 33.
} 
con el objetivo de proclamar el Informalismo como el estilo contenedor de la esencia nacional y trascendental del nuevo arte español. Finalmente, en 1949 d'Ors junto a Sebastià Gasch abrió el Primer Salón de Octubre de Barcelona, escaparate, entre otros, del grupo Dau al Set.

Un planteamiento ideológico para una estética del arte que cedía a la "innovación dentro de la tradición, individualismo, universalidad y trascendencia". Elementos también presentes en las discusiones en torno a la definición de un arte abstracto sometido a un "proceso de esencialización" que engendrase un "arte fuera del tiempo histórico ${ }^{77}$ ", dando lugar al I Congreso de Arte Abstracto de la Universidad Internacional Menéndez Pelayo de Santander, 1953. Este encuentro nacía de la inicial Escuela de Altamira, proyecto de Mathias Goeritz ${ }^{78}$, inspirado por "el carácter universal, supranacional, símbolo del arte fuera del tiempo histórico" del conjunto geológico de época prehistórica que dio nombre a la institución. La Escuela, aunque sin vinculación directa al aparato franquista, recibió el apoyo explícito de Manuel Fraga Iribarne, entonces secretario general del Consejo Nacional de Educación.

Además, hay que tener en cuenta otro factor. La ocupación alemana de Francia había provocado el desplazamiento del epicentro de creación artística mundial de París a Nueva York. El traslado de gran parte de los intelectuales, literatos, artistas, músicos, cineastas, arquitectos y diseñadores daría lugar a la conformación de nuevas experiencias creativas, resultado de la conjunción del bagaje que los artistas portaban consigo, la incidencia del trauma vivido y la asimilación de los nuevos lenguajes de los contextos de acogida. En otras palabras, la memoria del origen y la asimilación de los nuevos marcos de referencia -geográfica y cultural, sumada a las reflexiones sobre la condición vital de desterrado- conformarían nuevos rumbos en los procesos creativos de los artistas exiliados.

\footnotetext{
77 Ídem: 40.

${ }^{78}$ Goeritz, 1915-1990, artista multidisciplinar alemán afincado en México. En 1945 llegó a España, en Santillana del Mar dirigió el proyecto de la Escuela de Altamira como muestra de su inquietud por definir los postulados de la abstracción constructiva y sus ideas en torno a la arquitectura emocional.
} 
En la España de posguerra, sin embargo, esos nuevos lenguajes encontraban más dificultades para desarrollarse. Un ejemplo lo constituye el academicismo fotográfico para el que "el pictorialismo constituía la tendencia fotográfica más acorde con el espíritu triunfalista y mitificador de la nuevas autoridades, y con la miseria moral y artística de la dictadura ${ }^{79 "}$. El mayor exponente del pictorialismo español fue el fotógrafo José Ortiz Echagüe el cual, con su tetralogía Tipos y Trajes, 1930, España, Pueblos y Paisajes, 1939, España Mística, 1943, y España, Castillos y Alcázares, 1956, ejemplifica la idea de un pictorialismo basado en el folclorismo.

\subsubsection{El Informalismo, la vanguardia propiamente española}

El proyecto de definición de las nuevas formas del arte contemporáneo español iba a generar un gran debate ideológico en el seno de la intelectualidad falangista, enmarcado en el contexto internacional de nacimiento de la Abstracción tras la caída de los ismos, y de su confrontación con el Realismo figurativo. En el contexto de las discusiones internas del régimen, liberales y conservadores coincidían en que "la cultura en España, desde prácticamente la Generación del 98, se define en unas claves muy precisas: aporta unidad nacional, genera la identidad (y no al revés), plasma la dimensión espiritual del hombre $\mathrm{y}$, por tanto, tiene proyección universal ${ }^{80 "}$. Razones por las que el Informalismo se erigía en el movimiento artístico susceptible de ser legislado por el Estado sintiéndose este "heredero del Kunstwollen ${ }^{81 ” . ~ L a ~ d i r e c c i o ́ n ~ p o l i ́ t i c a ~ d e l ~ n u e v o ~ a r t e ~ s e ~ c a n a l i z o ́ ~ a ~ t r a v e ́ s ~ d e l ~}$ Instituto de Cultura Hispánica, que difundió y consolidó el Informalismo como paradigma de la vanguardia española: "el $\mathrm{ICH}$ hizo suya la vanguardia española y la vanguardia española hizo propio el $\mathrm{ICH}^{82 "}$.

\footnotetext{
${ }^{79}$ López, 1999: 177.

80 Marzo, 2010:66.

81 Ídem: 76.

82 ídem: 47.
} 
La irrupción del Formalismo americano se hizo dominante en este período. Los escritos de Clement Greenberg (1909-1994) y Harold Rosenberg (19061978) se centraron en la definición de un arte americano propio, alejado de las formas europeas, lo cual implicaba la negación de lecturas externas a la obra, la desposesión de cualquier herencia, la despolitización del artista y el fin de toda contaminación foránea. La focalización de Greenberg se presentaba propicia para el desarrollo del Informalismo español y explica el entendimiento fluido con el recién nacido Expresionismo Abstracto. El Informalismo se caracterizó por la abstracción y el protagonismo de la materia y de un tipo de artista que, huyendo de estructuras previas, se entregaba a la improvisación, constituyendo la obra el resultado del azar. Por todo ello, el Informalismo, como también sucediese en la corriente del Expresionismo Abstracto, perseguía la idea del arte como expresión de la individualidad. En definitiva, se erigió como la única vía posible para un arte de posguerra.

La figura del genio aislado pronto fue utilizada por el aparato franquista en su retórica aperturista ya que entendía el Informalismo "como el movimiento de vanguardia típica y netamente español ${ }^{83 "}$. La figura de Joan Miró (18931983) "personificaba el compromiso íntimo, autónomo e indestructible del artista con su propia obra". Miró, partidario de la República durante la guerra, decidió volver a España tras la retrospectiva que le dedicó el MoMA de Nueva York en 1941. Del mismo modo que sucediese con Pablo Picasso, los dirigentes franquistas eclipsados por el reconocimiento internacional del artista catalán, y teniendo en cuenta las tesis sobre la inoperancia política de las artes plásticas, acogieron a Miró en el seno de su andamiaje propagandístico. Este "dejarse hacer" por parte de Miró fue fuertemente criticado por el pintor Eduardo Arroyo $^{84}$, puesto que la vuelta del artista catalán aportaba cierta normalización a la escena cultural y social de la España de la dictadura lo que comportó que el régimen lo tomase como la quintaesencia del artista español. Algo semejante ocurrió con Antoni Tàpies,

\footnotetext{
83 Ídem: 62.

${ }^{84}$ En la década de los sesenta Arroyo criticó a Miró el "haber favorecido implícitamente al régimen al dar la imagen de cierta liberalidad a la hora de poder trabajar en España". Reproducido en Marzo, 2010: 61.
} 
elogiado por Camilo José Cela en la revista Papeles de Son Armadans, 1960, hasta el punto de exhibirlo como heredero de una larga tradición de las artes españolas en que figuraban Menéndez Pidal, Azorín o Picasso. Y, finalmente, del poeta falangista Luis Felipe Vivanco, del que se decía continuador del arte moderno español iniciado por Goya ${ }^{85}$.

En definitiva el objetivo político del Informalismo ensalzado por el régimen franquista preveía paliar la pobreza intelectual de la España de los años cincuenta. A su vez, respondió a la voluntad por controlar la posible agitación social "condicionando culturalmente al pueblo, a fin de asegurar su pasividad, mediante la exaltación de valores ancestrales como la "monarquía católica" o la "vida social comunitaria" que obrasen como antídotos del "pensamiento individual racionalista" tal y como afirmaba López-Amo en El poder político y la libertad. La monarquía de la reforma social, 1987.

\subsubsection{El intercambio cultural de la alianza hispano- norteamericana}

En el nuevo contexto diplomático hispano-norteamericano, las sinergias del Informalismo con el Expresionismo Abstracto propiciaron el intercambio de artistas. Los informalistas españoles expusieron en el MoMA y los abstractos estadounidenses se exhibieron en las Bienales Hispanoamericanas de Arte. Una etapa de buen entendimiento que arrancaba con la llegada al Palau de la Virreina de Barcelona y al Museu d'Art Contemporani de la muestra El Arte Moderno en los Estados Unidos ${ }^{86}$ de los fondos del MoMA de Nueva York.

La repercusión de los encuentros artístico-culturales sirvió para inyectar credibilidad a las nuevas políticas culturales franquistas y en especial a la

\footnotetext{
85 Ídem: 66.

${ }^{86}$ Cuyo título completo es El arte moderno en los Estados Unidos. Pintura, escultura, grabado, arquitectura. Selección de las colecciones del Museum of Modern Art de Nueva York. Exposición presentada también en el Museu d'Art Modern de Barcelona del 24 de septiembre al 24 de octubre de 1955.
} 
intervención de los sectores más liberales del régimen. La actuación paralela de todos los agentes participantes -el gobierno a través del Ministerio de Cultura, artistas y críticos- tuvo como resultado la construcción de un movimiento artístico informalista a imagen y semejanza del resto de occidente, con la particularidad que esta producción artístico-cultural se había puesto al servicio de la diplomacia franquista. Cabe resaltar que el nuevo control del Estado ya no se regía por la militancia de los artistas y autores bajo los dictámenes del régimen, ni por la idoneidad de sus presupuestos patrióticos morales, si no por la aceptación de formas expresivas políticamente inocuas, precepto que valió al régimen sumar adeptos a su proyecto cultural.

La vía cinematográfica fue otra de las vías por las que el influjo norteamericano llegó a suelo español. Las productoras hollywoodienses y su Star System ocasionaron un gran revuelo en la España de mediados del siglo XX. El productor independiente Samuel Bronston llegó a España tras ser uno de los muchos afectados por el desmantelamiento del sistema de estudios clásico en 1948 debido al aumento de los costes de producción y a la necesidad de nuevos mercados para su posterior explotación comercial. Factores que obligaron a la industria norteamericana a desplazarse con el fin de abaratar los costes de sus proyectos. España, en cambio, ofrecía muchas facilidades administrativas, un devaluado salario del personal técnico y unos paisajes exóticos vírgenes para el ojo de la cámara extranjera. Este fue el momento en que se exprimió el potencial del desierto de Almería como plató de rodaje de westerns siendo Tierra brutal de Michael Carreras, 1961, la primera película allí rodada. También la United Artists escogió España para rodar parte de Alexander the Great de Robert Rossen, 1956, The Pride and the Passion de Stanley Kramer, 1957, Suddenly Last Summer, de Joseph L. Mankiewicz, 1959 o Espartaco de Stanley Kubrick, 1960, entre muchos otros títulos. Bronston crearía Samuel Bronston's Inc para llevar a cabo el rodaje en España de King of Kings de Nicholas Ray, 1960. O El Cid, 1961 y The Fall of the Roman Empire, 1964, de Anthony Mann. La relación del productor norteamericano con España fue tal que creó la productora Samuel Bronston España con la que accedió legalmente a las subvenciones nacionales para 
rodar 55 days in Pekin de Nicholas Ray, 1963. Un panorama que se completará posteriormente con la descripción de la industria cinematográfica nacional.

\subsection{La consideración franquista del campo español}

"Creían muchos españoles, las clases directivas españolas, que España estaba solamente en las capitales y en las ciudades, y desconocían la realidad viva de los pueblos y de las aldeas, de los lugares más pequeños, las necesidades, la vida, muchas veces infrahumana, de grandes sectores de la Nación, y todo ello es lo que el Movimiento ha venido a redimir, capacidad creadora incomparable que está forjando un gran programa nacional de todas las provincias ${ }^{87 "}$.

Estas palabras fueron pronunciadas por el general Francisco Franco en el discurso de aceptación de la Primera Medalla de la provincia de Valladolid en 1959. Junto a los generales Sanjurjo y Mola en julio de 1936 Francisco Franco Bahamonde (1892-1975) había liderado un golpe de Estado contra el gobierno de la Segunda República española desencadenando una Guerra Civil que se prolongó desde el 17 de julio de ese año hasta el 1 de abril de 1939. Su proyecto político-militar comprendía tres fases. Una primera de alzamiento militar, seguida del enfrentamiento armado que conllevaría "graves daños y dolores", un mal necesario en opinión del ministro de gobernación Ramón Serrano Suñer ${ }^{88}$ que daría paso a una estrategia resumida por el historiador Richardson: "Through hunger, imprisonment, and impoverishment, the Spanish populace could redeem itself from the sins of the masonic, communist, and liberal ideas that had necessitated the war ${ }^{89}$ ". Finalmente, se contemplaba una fase de reconstrucción de un país desolado física y moralmente. Esta última fase se fundamentó sobre una estrategia en que el campo español iba a erigirse en germen de la España verdadera,

\footnotetext{
${ }^{87}$ Reproducido en del Molino, 2016: 59.

${ }^{88}$ En su discurso reproducido en la revista Reconstrucción, núm. 3, extraordinario junio-julio 1940.

${ }^{89}$ Richardson, 2012: 32. "De entre el hambre, la reclusión y el agotamiento el pueblo español puede redimirse a sí mismo desde el pecado masónico, comunista e aquellas ideas liberales que necesitaban de una guerra". Traducción de la autora.
} 
puesto que económicamente constituiría una insoslayable fuente de abastecimiento para el sistema autárquico que regiría el país. Además de constituirse moralmente en el contenedor de los valores patrios donde acudir para definir al nuevo ciudadano español.

El ideal autárquico del régimen franquista encontraba en el espacio rural su fuente de abastecimiento. La idea recuerda al planteamiento de Política ${ }^{90}$ de Aristóteles que advertía sobre al necesidad de poner cuidado en que los campos que rodean la ciudad puedan proporcionarle el sustento necesario porque así podrá resistir con éxito el ataque de sus enemigos. Un principio aristotélico, de carácter bélico-defensivo, presente en la publicación del urbanista valenciano César Cort Botí ${ }^{91}$, Campos urbanizados y ciudades rurizadas $^{92}$, 1941, al argumentar que "la prosperidad de las ciudades se engendra en los campos, y que sin campos atendidos, cultivados y lozanos no hay ciudades con vitalidad ${ }^{93}$ ". Asimismo en su visión inclusiva de las realidades de la España de posguerra Cort promulgaba que "no hay nación grande con municipios abandonados, enclenques, torpes o venales" llegando a considerar injusto el hecho que los habitantes del campo pagasen "con su pobreza y abandono nuestra incuria e incapacidad ${ }^{94 "}$.

El interés por el entorno rural se inspiró, salvando las distancias con la constitución puramente militar del régimen franquista, en la línea ideológica de los fascismos que defendían que "el porvenir de las naciones vuelve a estar en la tierra donde se alimentan las raíces de la más firme riqueza nacional. Así lo han entendido Mussolini (Agro Pontino) y Hitler (Danktag)", promulgaba Nemesio García Pérez en la revista Agrarismo y Jonismo ${ }^{95}$ ya en 1933. Un interés que guardaba una función legitimadora del ideario franquista

\footnotetext{
${ }^{90}$ Consultada la edición traducida por Pedro Simón Abril, 1925.

${ }^{91}$ Concejal monárquico del Ayuntamiento de Madrid durante la II República, fue el primer catedrático de urbanismo en España. Durante la dictadura franquista se enriqueció con la compra de terrenos del extrarradio de Madrid y con el control del Mercado del wolframio, metal utilizado por los nazis para el revestimiento de su maquinaria de guerra.

${ }^{9}$ Publicado en Madrid por la Federación de Urbanismo y de la Vivienda de la Hispanidad.

${ }_{93}^{93}$ Reproducido en del Molino, 2016.

94 Jiménez-Blanco, 2016: 149.

${ }^{95}$ Reproducido en Jiménez-Blanco, 2016: 141.
} 
en construcción como también sucediese en el fascismo italiano ${ }^{96}$. En el contexto de la Guerra Civil Española, el bando sublevado puso especial empeño en sumar simpatizantes a su causa, entre ellos campesinos sin tierra y clase trabajadora ${ }^{97}$ del campo español considerados "as the embodiment of national virtues [and] an important ingredient in the Francoist Project of national unification", en palabras de Michael Richards ${ }^{98}$.

José Antonio Primo de Rivera (1903-1936), fundador del partido Falange Española, FE, basó su estrategia de expansión política en una acción pública que comprendía tanto ciudades y capitales de provincia como pequeños núcleos rurales. De hecho los viajes a aldeas españolas provocaron el enfrentamiento de Primo de Rivera con Ramiro Ledesma (1905-1936), fundador de la Junta de Ofensiva Nacional-Sindicalista, JONS. Este último criticó que "el esfuerzo de la organización, en su capítulo de propaganda, se agotó en siete actos celebrados en aldeas y pequeñas ciudades, sin relieve social ni realidad política alguna”. Si bien, en 1935 Ledesma volvía sobre sus palabras para reconocer que "no era quizá del todo absurda esa opinión de Primo, que respondía a un afán por entrar en contacto con la España mejor, la España de los campos ${ }^{99 "}$. Como señala Ferrán Gallego, Ledesma se retractaba teniendo en cuenta que el discurso campesinista había ocupado en 1931 un puesto central en el proyecto político e ideológico de las JONS contemplándose, incluso, la constitución del Bloque Social Campesino. El dirigente falangista consideraba a los habitantes del entorno rural como "los depositarios del verdadero espíritu nacional", mientras que el cofundador de FE, Julio Ruiz de Alda, ya advertía en 1934 de la influencia dañina de las

\footnotetext{
${ }^{96}$ También el fascismo italiano proponía la "vuelta integral al agro" donde se localizaba la idea del "buen campesino domesticado, laborioso y fiel a sus amos, tradicional e inofensivo, que había apasionado al pensamiento patriarcal y quietista", argumenta Alexandre Cirici explicando a su vez como Mussolini "había sabido ligar esta imagen idílica con su temática agresiva. El campesino le servía para tipificar al hombre popular que -significativamente- no era obrero ni ciudadano ni funcionario, sino que existía, como dice Giménez Caballero, "simplemente como hombre elemental... como hombre eterno". Cirici, 1977: 74.

${ }^{97}$ Sostiene Cazorla Sánchez, 2016: 43.

${ }^{98}$ Richards, 1996: 151. "Como la personificación de las virtudes nacionales y un importante ingrediente en el proyecto franquista de unificación de la nación”. Traducción de la autora.

${ }^{99}$ Gallego, 2014: 252.
} 
ciudades sobre los pueblos ${ }^{100}$. Dos ideas que se repetirían en los discursos de los dirigentes franquistas y del propio caudillo.

Es interesante constatar como el interés de Falange Española hacia la España rural iba al encuentro con la masa campesina con tendencia al voto a la derecha y dependiente de los sindicatos católicos, como ocurrió en Castilla la Mancha. La situación era que las fuerzas de derecha se movían en colaboración, no dejando espacio objetivo para que FE se erigiese como partido-milicia articulador de un discurso -y práctica- al servicio de la contrarrevolución ${ }^{101}$. Finalmente, el encuentro con el campo español sirvió a FE para imprimir carácter populista a su estrategia política apropiándose de la exclamación "salud y revolución" que los campesinos lanzaban al cortejo fascista de Primo de Rivera en la visita a Carpio del Tajo dentro de los actos de propaganda de FE realizados entre febrero y julio de 1934.

\subsubsection{El plan de reconstrucción nacional del régimen franquista}

"The Achilles heel of Francoism was formed in part, however, by the gap between the regime's representations of space and their actual spatial practice $^{102 " .}$

La Guerra Civil dejó un país devastado. El régimen franquista se propuso construir desde los cimientos la nación española "overtly attempted to employ space as a key weapon in their blitzkrieg of Spanish identity ${ }^{103 "}$. Iniciaba una etapa que el mismo dictador definió de años de renacimiento, para la que se creó el Instituto de Crédito -ya en plena guerra-, la Dirección General de Regiones Devastadas y Reparaciones -por Ley del 30 de enero de 1938 y

\footnotetext{
${ }^{100}$ Ideas recogidas en el semanario "F.E de las J.O.N.S en Puebla de Almoradiel". En F. E., 12. 26 de abril de 1936, 6-7.

101 Gallego, 2014: 256.

102 Richardson, 2012: 34. "El talón de Aquiles del régimen franquista en parte estaba formado por el espacio entre las representaciones espaciales del régimen y las prácticas espaciales reales". Traducción de la autora.

103 Ídem: 33. "Abiertamente dirigida a utilizar el espacio como arma en el proyecto de identidad española". Traducción de la autora.
} 
activa hasta 1957- y el Instituto Nacional de Colonización -en funcionamiento de 1939 a 1971. Todo ello con el objetivo de continuar la transformación del mundo rural iniciada a principios de siglo atajando los problemas de sequía, la carencia de electrificación y general atraso técnico del campo español.

El plan de reconstrucción comprendió varios ejes de actuación. El primero de ellos es el comúnmente llamado Plan Badajoz, el Plan de Obras, Colonización, Transformación y Electrificación de la provincia de Badajoz el cual adoptaba forma de ley el 7 de abril de 1952 y se extendió en diferentes fases hasta 1971. Esta región era paradigmática de los problemas de sequía y despoblación que adolecían al campo español que ya abordadó el gobierno republicano estando al frente del Ministerio de Fomento Rafael Gasset. El Plan tomó como fuente principal de abastecimiento el río Guadiana en cuya cuenca se construyeron los embalses de Cíjara, García de Sola, Orellana, Montijo y del afluente Zújar ${ }^{104}$. El objetivo era regular el cauce del río, producir energía eléctrica y dotar de agua de riego las vegas del Guadiana. Además se preveía una red de carreteras y vías férreas que ayudarían a la repoblación de la zona, lo que conllevó la construcción de pueblos de nueva planta, a cambio de la anegación de aquellos donde se ubicaban las obras hidráulicas. Esta reorganización precisaba de la llegada de colonos ante la promesa de unas tierras que ahora darían fruto. La parte social del proyecto se dirigió desde el Instituto Nacional de Colonización que tenía como objetivo reorganizar el espacio productivo del país y en concreto reactivar la producción agraria de las provincias de Extremadura y Andalucía.

El segundo lo constituyó la arquitectura monumental con obras faraónicas, emblema del poderío del régimen, como los edificios de Nuevos Ministerios, la Ciudad Universitaria, el Arco de la Victoria o el Valle de los Caídos. Además del adorno de las plazas mayores con monumentos en honor a Franco, el general Mola y Primo de Rivera. Y la construcción de "nuevas casas y nuevos pueblos de España cimentados sobre la lección ejemplar de

\footnotetext{
${ }^{104}$ Fuente embalses.net. [Consultado: 15 agosto 2019: https://www.embalses.net/cuenca-6guadiana.html.].
} 
aquellas piedras que la guerra removió ${ }^{105 "}$ afirmaba en sus discursos el ministro de la gobernación Serrano Suñer. Una referencia a la reconstrucción de los pueblos devastados durante el conflicto bélico pero también de aquellos de nueva planta surgidos al amparo del proyecto del Instituto Nacional de Colonización que llegó a construir 300 pueblos entre 1945 y 1970 en las cercanías de los ríos Duero, Tajo, Guadiana, Guadalquivir y Ebro.

También se contempló la adopción de pequeños municipios a modo de mandato fundacional de las cartas pueblas de la Edad Media. En el fulgor de ensalzamiento patriótico del régimen franquista lo rural adoptó carácter popular junto a los elementos de familia y hogar, dos de los pilares fundamentales del nacionalcatolicismo. Alexandre Cirici en La estética del franquismo analiza a estrategia reconstructiva de los pueblos españoles la cual respondía a "la mitificación del modelo campesino de vida", el cual, desde la perspectiva franquista equivalía a lo elemental y lo eterno. Por ello la adopción de dicho modelo devolvería al "proletariado la conciencia de la dignidad de su clase". Una estrategia comprendida en el ideario de un régimen totalitario que, en su afán neutralizador de la conciencia crítica, arremetía contra todo elemento tradicionalmente pintoresco -como los arcos por encima de las calles o voladizos- considerados típicos del oscurantismo medieval. El resultado fue la construcción de nuevos barrios, durante los últimos años de la década de los 40 y principios de los 50 , alrededor de plazas cerradas y calles cruzadas por arcos que, imitando el modelo rural, tomaban como centro monumental la iglesia, una construcción que, a diferencia de la humildad de las viviendas rústicas domésticas, no escatimaba en altos campanarios rematados por obeliscos, "verdadera forma del espiritualismo, señalando al cielo y elevándose por encima de los mortales $^{106 "}$.

En la construcción de nueva planta de poblaciones como Esquivel, proyectada por Alejandro de la Sota, se tomó como referente de planificación

\footnotetext{
${ }^{105}$ Reconstrucción, núm. 3, extraordinario junio-julio 1940.

${ }^{106}$ Cirici, 1977:135.
} 
urbanística la Italia fascista a base de bloques de viviendas aislados "a menudo como dominós plantados en direcciones perpendiculares o paralelas entre sí", explica Cirici añadiendo que:

"No hubo locales de reunión ni bibliotecas, ni tan sólo, en muchos casos, se preveían tiendas, instituciones que sirven para la vida social en tantos pueblos. Había una expresa voluntad de aislar a los habitantes y de dificultar su intercomunicación. Los habitantes tenían que estar cohesionados por un punto de convergencia común, situado fuera de ellos mismos, en la iglesia pero no de intercambio directo, y al mismo nivel de unos con otros ${ }^{107 "}$.

En los planteamientos arquitectónicos había voluntad por mejorar las condiciones de vida de sus habitantes, pero la urgencia y austeridad del proyecto pronto redujo la premisa a los básicos de funcionalidad e higiene, proveyendo, eso sí, de "alma cada zona de España a través de la recreación de ambientes tanto en las calles como en el interior de las casas, decoradas con objetos y muebles de inspiración popular ${ }^{108 ", ~ e x p l i c a ~ L e t i c i a ~ S a s t r e . ~ E l ~}$ proyecto de reparación arquitectónica se teorizó en las páginas de Reconstrucción, la revista oficial de la Dirección General de Regiones Devastadas, que en su momento constituyó un catálogo de las tipologías constructivas.

Durante el período de autarquía las nuevas construcciones mostraban el rechazo a todo vínculo estético con el período de la II República y la negación de cualquier influencia de los "ismos" de la vanguardia francesa, entre otros, por considerarlos faltos de contenido vital, como justificaba el arquitecto manchego Miguel Fisac, y se ha desarrollado anteriormente. En definitiva el estilo artístico oficial del régimen franquista buscaba el enlace directo con la tradición, y lo encontró en los regionalismos, una iniciativa que lo vinculaba al interés creciente en el resto de Europa por la arquitectura tradicional ${ }^{109}$, sostiene Sastre.

\footnotetext{
${ }^{107}$ Ibídem.

108 "El sol, la cal y la sal. Arquitectura rural en el período de la autarquía". En Jiménez-Blanco, 2016: 142.

${ }^{109}$ lbídem.
} 
La década de los años cincuenta inició con una tímida predisposición a la interpretación moderna de lo popular una vez agotadas las fórmulas del pintoresquismo. Antes, a finales de la década de los cuarenta Miguel Fisac había declarado que "copiar el arte popular o clásico español conduce al folklore o la españolada. Extraer su esencia, saber sacar esos ingredientes de verdad, de modestia, de alegría, de belleza que tiene, sería encontrar el camino de una nueva arquitectura y, en general, de un arte nuevo ${ }^{110 " .}$

La labor asistencial de la Sección Femenina de FET-JONS dotaría de dimensión social la línea de reconstrucción arquitectónica de la España de posguerra. Con una estructura orgánica que abarcaba de las capitales de provincia hasta los asentamientos rurales, las militantes falangistas voluntariamente se dedicaban a "reeducar a las españolas en los principios barrocos de la 'perfecta casada'111". La ocupación de los puestos formativos por parte de mujeres de la Sección Femenina fue un proceso relativamente rápido, sobre todo teniendo en cuenta la desaparición de profesionales de la educación como consecuencia de la Guerra Civil. También la Hermandad de la Ciudad y del Campo desempeñó una labor importante. El objetivo principal de la organización -creada durante la Guerra Civil- fue encargarse de los cultivos abandonados tras la movilización militar, y frenar el éxodo rural en un contexto de miseria generalizada. El proyecto pretendía "potenciar las industrias rurales y fomentar su enseñanza entre las amas de casa", proyecto que asumiría la FET-JONS en su política de fetichizar la industrialización frente al "campesinismo falangista ${ }^{112 ", ~ s o s t i e n e ~ S o f i ́ a ~ R o d r i ́ g u e z . ~}$

Sin embargo, el fenómeno que definió la vida española fue el éxodo rural y la emigración general que empezaba a sentirse a finales de los años cuarenta y se constató en la década de los 50 alterando irremediablemente el mapa demográfico español. Las consecuencias económicas del impacto de la Guerra Civil española se dejaron ver en la agricultura, más empobrecida si

\footnotetext{
${ }^{110}$ Miguel Fisac. "Estética de Arquitectura. Ponencia V Asamblea Nacional de Arquitectura". En Boletín de Información de la Dirección General de Arquitectura. Madrid, junio de 1949, vol. IV, núm.11. Reproducido en Jiménez-Blanco, 2016: 143.

${ }_{111}^{11}$ Amador y Ruiz, 2007:291.

112 Ídem: 299.
} 
cabe, y en el estancamiento de la industria, lo cual apuntaba a la inviabilidad del sistema autárquico propuesto por el franquismo. Al terminar la Segunda Guerra Mundial se reanudaron las vías de comunicación trasatlánticas y con ello las emigraciones. En La política de emigración a través de la historia del IEE ${ }^{113}$ detalla Axel Kreienbrink como en 1949 las personas emigradas ascendían a 50.000 con un promedio anual entre 1949 y 1958 de 57.000. Entre 1946 y 1958 abandonaron el país aproximadamente 624.000 personas. Pero en contra de la evolución del fenómeno el régimen franquista prohibió la emigración por Decreto de 1 de agosto de 1941. Las motivaciones apuntaban a los objetivos demográficos del gobierno que aspiraba a incrementar la población española de 26 a 40 millones, las posibles influencias políticas. En 1946 volvía a entrar en vigor la Ley de Emigración en su versión de 1924, aunque permanecieron ciertas disposiciones restrictivas del período de guerra, cuyas competencias pertenecían a la cartera de Trabajo ${ }^{114}$.

María José Fernández Vicente en el capítulo La evolución del organigrama migratorio español: el papel del IEE localiza en el seno del Instituto de Cultura Hispánica la creación del Instituto Español de Emigración, IEE, mecanismo mediante el cual canalizar el flujo migratorio dentro de las políticas de exportación de los referentes identitarios nacionales al continente Sud Americano. EI IIE se convirtió en el organismo encargado de aplicar una política pública en materia de emigración por Ley de 17 de julio de 1956 solapándose sus competencias con las del Ministerio de Trabajo atribuidas por ley desde 1924 a 1960. Aunque el papel de estos organismos fue insuficiente pues atendiendo al potencial migratorio de las zonas rurales de Andalucía, Extremadura y Castilla. Por ejemplo, entre las atribuciones al IIE se encontraba la tarea de informador de las ofertas de empleo para lo cual requería inscribirse como candidatos en las oficinas de provincia, lo cual

\footnotetext{
${ }^{113}$ Calvo Salgado et alii, 2009: 13-34.

114 Explica María José Fernández Vicente como en 1938 el Ministerio de Trabajo había sido sustituido por el Ministerio de Organización y Acción Sindical (MOAS) dividido a su vez en cinco servicios nacionales. Uno de ellos se dedicó a la Emigración el SNE. Al finalizar la guerra el MOAS se convirtió de nuevo en el Ministerio de Trabajo. En Calvo Salgado et alii, 2009: 35-64, 41.
} 
suponía un problema para los habitantes de las zonas rurales al no poder costearse los desplazamientos.

En definitiva la falta de trabajo general y el empobrecimiento del campo español resultó en el desplazamiento de aproximadamente 4 millones de españoles del campo a la ciudad entre 1951 y 1970. Llegados a 1975 el 26,6 por ciento de la población vivía en provincias diferentes a su lugar de nacimiento. Madrid había crecido en dos millones de habitantes y hasta cuarenta ciudades superaban los 100.000 habitantes. La transformación espacial del país supuso la pérdida de 547 centros de población y con ello el hacinamiento de los emigrantes rurales en las ciudades de Madrid, Barcelona y Vizcaya, principalmente, un fenómeno social que fundamentó el argumento de Surcos de José Antonio Nieves Conde, 1951. La película describe las trabas a las que tiene que hacer frente una familia campesina en su proceso de adaptación a Madrid. Entre ellas el problema de la vivienda, al haber de compartir la familia protagonista habitáculo con los parientes que les acogen, y enfrentarse cada uno de ellos a la ardua empresa de encontrar trabajo. Particularmente interesante es el caso del padre -protagonizado por Luis Peña- menospreciado por una sociedad a la que no consigue adaptarse por su edad.

El sentido unidireccional del fenómeno migratorio reveló la uniformidad de origen social y territorial del medio rural. Debido, principalmente, a la constitución de estas comunidades por grandes familias asentadas sobre fuertes lazos de parentesco que aseguran la efectividad de la intervención familiar en el cumplimiento de los códigos de conducta y las normas de la comunidad. Este fenómeno constitutivo de la comunidad rural dio pie a la teoría de Wladyslaw Grabski, sobre la familia como principio de la aldea ${ }^{115}$. En opinión de Boguslaw Galeski, el modelo de comunidad aldeana "funciona como una unidad de control social; como fuente de un sistema vinculante de normas y valores; como grupo de referencia que define la posición del individuo y de la familia, y como un factor esencial en la asimilación social de

${ }^{115}$ Grabski. "Sociología rural sistemática”. En Anales de Sociología Rural, vol. IV, 1936. 
la generación joven ${ }^{116 " . ~ U n ~ f a c t o r ~ q u e ~ c o n s t i t u y e ~ l a ~ b a s e ~ d e l ~ g e ́ n e r o ~ d e l ~}$ drama rural como ilustran La Laguna Negra de Arturo Ruiz-Castillo, 1952, Sierra maldita de Antonio del Amo, 1954, o Orgullo, de Manuel Mur Oti, 1955.

${ }^{116}$ Galeski, 1977: 151. 


\section{Aspectos fundamentales de la cinematografía española de los años 50}

Desde una perspectiva historiográfica el trama 1951-1961 constituyó un período de crecimiento del sector cinematográfico nacional en términos de reactivación de la demanda, de aumento de la producción ${ }^{117} \mathrm{y}$, con ello, de expansión del mercado cinematográfico ${ }^{118}$. El auge de la producción cinematográfica era el resultado de la transformación del modelo de protección estatal sumado al fenómeno de las coproducciones y el establecimiento de una cuota de distribución.

En detalle, el panorama industrial cinematográfico español de los años cincuenta estuvo fuertemente condicionado por el tejido legislativo y comercial que, a principios de década, arrastraba el modelo de posguerra basado en la protección económica del Estado y el sometimiento a los dictámenes censores franquistas y de la Iglesia católica. Unas circunstancias que sumieron al sector en una posición acomodaticia ${ }^{119}$ respecto al desarrollo de nuevos modelos de implementación de la calidad de la producción ${ }^{120}$. El férreo intervencionismo del Estado de los años de posguerra asentaría unos patrones de conducta -tanto del régimen como de los sectores industriales participantes- basados en la especulación como garantía del rédito económico inmediato de las empresas cinematográficas. En paralelo al revulsivo modernizador que supondría el Plan de Estabilización de 1959, la

\footnotetext{
${ }^{117}$ La década iniciaba con un ligero descenso de la producción hasta que en 1954 se produce un aumento imparable hasta finales de la década, momento en que se dobla la cifra de películas producidas. En 1950 se estrenan 48 películas, de las cuales 45 son nacionales y 3 coproducciones. En 1951 y 195241 películas, en 195343 películas. En 1954 la producción aumenta hasta los 68 títulos -56 y 12; desciende ligeramente en 1955 hasta los $56-49$ y 7 . 75 títulos en $1956-53$ y 22; 72 en $1957-50$ y 22; 75 en $1958-51$ y 24. Un ascenso vinculado a la exigua presencia del cine norteamericano debido al boicot de la MPAA. En 1959 tiene lugar un ligero descenso hasta los 68 títulos, 51 y 17, y finalmente se producen 73 películas en $1960-55$ y 18; 91 en $1961-72$ y 19 y 88 en $1962-61$ y 27 , como primeros resultados de la inyección de capital a través del Crédito Oficial. Monterde et alii, 1996: 256.

${ }^{118}$ Según datos de Monterde et alii, 1996: 206. A nivel interno el parqué de salas creció un $90 \%, 3.502$, entre 1950 y 1961. Un crecimiento que contiene una lectura social. La miseria material y moral de la España de los cincuenta arrastraba a la sociedad a refugiarse en los espectáculos taurinos, cafés, taberna y cines.

${ }^{119}$ Panorama que daría pie al dictamen en forma de pentagrama de Juan Antonio Bardem y que también los hermanos Pérez Merinero tachaban de raquítico, miserabilista, ocasionalista, marginal y provinciano. Pérez Merinero, 1975: 43.

120 Resulta interesante constatar como la intervención del Estado sobre el sector cinematográfico provenía principalmente del Ministerio de Comercio e Industria.
} 
década concluía con la eclosión del Nuevo Cine Español como síntoma del relevo generacional de los realizadores y las empresas productoras y el surgimiento de nuevas fórmulas que, por ejemplo, darían por agotado el ciclo de cine histórico.

\subsection{Formas de censura}

\subsubsection{Censura jurídica}

Dentro de la constitución del Estado franquista durante la Guerra Civil española se creó el Departamento Nacional de Cinematografía que, entre otras funciones, desempeñó tareas censoras. En el reglamento de 1 de abril de 1938 se anunciaba que "El Estado ejercerá la vigilancia y orientación del cine a fin de que éste sea digno de los valores espirituales de nuestra patria". Al tiempo que se prestaba a desarrollar funciones productoras al establecer que "el Estado, en todo caso, se reserva la producción de noticiarios y documentales políticos y de propaganda". Más allá del afán por dominar una faceta más de la vida española, el intervencionismo del Estado en materia cinematográfica discurrió en la línea que plasmó el preámbulo de la Orden de 2 de noviembre de 1938 de regulación de la censura:

"Siendo innegable la gran influencia que el cinematógrafo tiene en la difusión del pensamiento y en la educación de las masas, es indispensable que el Estado vigile en todos los órdenes en que haya riesgo de que se desvíe de su misión. La experiencia del sistema hasta ahora seguido aconseja introducir algunas modificaciones y completar las normas sobre la materia".

Aunque previamente ya se había empezado a definir una estructura jurídica en materia de censura cinematográfica. Por Orden de la Delegación del Estado para Prensa y Propaganda de 18 de noviembre de 1937 se creó la Junta Superior de Censura Cinematográfica con sede en Salamanca con el objetivo de controlar la idoneidad de los contenidos en materia política, religiosa, militar y de moral sexual. Se estaba modelando "la sistemática 
burocrática general que, con retoques de forma, permanecería en vigor en las décadas siguientes ${ }^{121 "}$. Y por la que se decretaba el carácter infalible de dicha institución como principio regidor al sentenciar que "los fallos de la Junta serán inapelables", (Art.4). Con fecha 2 de noviembre de 1938 se constituyó la Comisión de Censura Cinematográfica y la Junta Superior de Censura Cinematográfica, ampliación de la estructura existente desde noviembre de 1937 con la implicación de más sectores -entre ellos del Ministerio de Educación y distintas Jefaturas- en el comité censor. La medida supuso el ordenamiento de la actividad censora dejando el control de las producciones privadas de ficción a la Comisión de Censura mientras que la Junta Superior supervisaría la producción de noticiarios, documentales y demás producción estatal generada por el Departamento de Cinematografía. Ambos organismos también serían los encargados de establecer las cuantías económicas por emisión de derechos y sanciones así como de asignar a los gobernadores civiles y los alcaldes la vigilancia en sus respectivas jurisdicciones para la aplicación censora.

Y, finalmente, el 21 de marzo de 1952, se creó la Junta de Clasificación y Censura, ente bajo el que se congregarían las diseminadas actividades de la Junta Superior de Orientación Cinematográfica ${ }^{122}$, la Oficina Nacional Clasificadora de Espectáculos ${ }^{123}$ y la sección de Censura ${ }^{124}$, cuyos dictámenes adquiririan especial trascendencia en las subvenciones económicas concedidas a los proyectos audiovisuales. La vigilancia censora se caracterizó por su opacidad en el sentido de que no existían unos criterios o instrucciones concretas por las que regir sus dictámenes, primando en cambio el carácter arbitrario de sus resoluciones con las consiguientes contradicciones que ello suponía. Por el contrario sí se estableció la

\footnotetext{
${ }^{121}$ Gubern, 1981: 24.

${ }^{122}$ La cual por Orden del Ministerio de Educación Nacional de 28 de junio de 1946 ya nacía para refundar las Junta Superior de Censura Cinematográfica (18 noviembre de 1937) y la Comisión Nacional de Censura Cinematográfica. La misión era asumir las responsabilidades en materia de clasificación de la producción cinematográfica a efectos de protección económica además de la tarea de censura del propio material audiovisual.

${ }^{123}$ Entidad creada en 1950 en el seno de la Comisión Episcopal de Ortodoxia y Moralidad, encargada de la supervisión moral y sexual de las películas siguiendo los preceptos conservadores de la Iglesia católica.

${ }^{124}$ Castro de Paz et alii, 2005: 81.
} 
composición de los comités censores de la Junta Superior y del Gabinete de Censura Cinematográfica de Sevilla formados por delegados institucionales, un representante de la autoridad militar, un representante de la Falange Española Tradicionalista y de las JONS y uno de la Iglesia católica. Este era en palabras de Román Gubern el triunvirato censor.

La creación de todos estos organismos constata el afán ordenancista del régimen franquista que constriñó el desarrollo de la industria cinematográfica española ya de por sí mermada tras el conflicto armado y el consiguiente exilio y censura de realizadores, actores y demás trabajadores ${ }^{125}$ contrarios al régimen, además de la depuración de películas ${ }^{126}$ del período republicano. $A$ partir de entonces la industria cinematográfica sobrevivió marcada por la subsidiariedad económica y política del régimen franquista. Finalmente, cabe constatar como la nueva diplomacia del grupo tecnócrata del quinto y sexto gobierno franquista repercutió en la vida cultural y en concreto en la actividad censora para la cual, a mayor flujo de influencias extranjeras, mayor peligro y con ello necesidad de control. Una situación que dibujó un panorama de tensión en el interior del país a la vez que de contrasentidos al chocar los dictámenes censores nacionales con los modelos de las industrias europea y norteamericana, lo que abrió ciertas fisuras desde donde asomarían actitudes de cuestionamiento sobre la hegemonía de las estructuras industriales, jurídicas y estéticas del cine español del período, como posteriormente se desarrollará.

\footnotetext{
${ }^{125}$ Los casos personales de "Antonio del Amo, detenido en Valencia, encarcelado y condenado a muerte por la autoría de varios documentales republicanos, no pudo volver a dirigir hasta 1947. El realizador Fernando Roldán fue degradado a la condición de jefe de producción. Y María del Carmen Merino fue encarcelada durante el rodaje de Sarasete en 1941 y reemplazada por Luchy Soto". Gubern, 1981: 59.

${ }^{126}$ Como fue el caso de Nuestra Natacha de Benito Perojo, 1936, mandada destruir por el Departamento Nacional de Cinematografía sin haber sido estrenada. También la Pipo y Pipa en busca de Cocolín de Adolfo Aznar, 1936, fue confiscada antes de la existencia de la Orden ministerial de censura previa y obligatoria de guiones cinematográficos. Gubern, 1981: 60.
} 


\subsubsection{Censura moral}

La conjunción de la administración franquista y la Iglesia católica tuvo su impacto en el ámbito de la censura. La idea de cruzada ${ }^{127}$ surgida durante el conflicto armado impregnó incluso la producción cinematográfica del Movimiento Nacional, encontrando la primera muestra en el cortometraje Vía Crucis del Señor por tierras de España de José Luis Sáenz de Heredia, 1940, con guión de Manuel Augusto García Viñolas, miembro de la comisión de censura franquista.

En un primer momento la Iglesia católica se había posicionado en contra del cine por considerarlo al mismo nivel que el consumo de estupefacientes, un argumento surgido en base al alto flujo de frecuentación de las salas de cine. Al respecto se pronunciaba en las páginas de Ecclesia:

"Porque ya empieza a darse una cinemanía con los mismos caracteres agotadores de las fuerzas espirituales que los otros comercios de estupefacientes. Y aquí sí que sólo cabe un remedio: la abstención como vencimiento, la mortificación cristiana ${ }^{128 " .}$

Sin embargo, el ente religioso pronto tomó consciencia del potencial del medio cinematográfico para su campaña de difusión ideológica reclamando rápidamente la plena potestad en la baremación de los contenidos cinematográficos de acuerdo a los valores del credo cristiano. Una concesión por parte del régimen franquista que le permitió redefinir su influencia en el seno de la vida española mediante una acumulación de poder que en el ámbito cinematográfico "se tejió [a partir de] una generalizada presencia en los niveles de formación y educación cinematográfica ${ }^{129 " . ~ F u e ~ a s i ́ ~ c o m o ~ l a ~}$ Iglesia católica participó en la constitución del movimiento cineclubista a

\footnotetext{
${ }^{127}$ El proyecto franquista se entendió como cruzada en relación al sentido fundamental del término por el que la Santa Sede promulgó campañas contra los infieles a la doctrina cristiana.

${ }^{128}$ Editorial "La censura de películas". En Ecclesia, núm. 148. 13 de mayo de 1944, 1.

129 "Además "si a esto le unimos la profusión de documentos pontificios, episcopales y otros, como la amplia red de locales de proyección parroquiales, colegiales y además salas católicas conforman un espectro apresurado del poder de incursión que se puso en pie". Martínez, 1987: 4.
} 
través de Acción Católica e incluso incluyó secciones dedicadas al cine en sus publicaciones eclesiásticas. Obviamente, también tomó parte de la de los organismos de gestión de la actividad censora. Fue en 1950, con la creación de la Oficina Nacional Permanente de Vigilancia de Espectáculos, ${ }^{130}$ que se reconoció la censura oficial de la Iglesia "con carácter nacional y vinculante para todos los católicos ${ }^{131}$ ". Un protagonismo en el ámbito censor que le permitió publicar sus propias normas y tabla clasificatoria, alegando la falta de exigencia de la censura civil en pro de una censura religiosa vigilante del cumplimiento de la moral católica más estricta, lo cual a efectos prácticos acarrearía "una incómoda diarquía de juicios censores ${ }^{132 ", ~ s e n t e n c i a ~ R o m a ́ n ~}$ Gubern.

\subsection{Proteccionismo estatal}

El aparato cinematográfico estatal se constituyó durante los años cuarenta implementándose a lo largo de la década siguiente. Fue así como a partir de 1958 las Junta de Clasificación y Censura, la Comisión Superior de Censura Cinematográfica y el Consejo Coordinador de la Cinematografía se adscribieron al Instituto de Orientación Cinematográfica.

Al control del régimen franquista sobre los medios de comunicación, y en particular sobre la industria cinematográfica a través de la aplicación jurídica de la censura, se suma una estructura proteccionista basada en incentivos económicos que gratificaban a los productores con licencias de importación y doblaje de películas extranjeras. Un sistema que, en primera instancia, vinculaba la clasificación estético-moral a la subvención económica ${ }^{133}$ y cuya

\footnotetext{
${ }^{130}$ Momento en que se creó la escala de baremación desde el 1 , para todos los públicos, al 4 , película gravemente peligrosa, pasando por el 3-R indicando "mayores con reparos".

${ }^{131}$ Gubern et alii, 2009: 250.

132 Gubern, 1981:106.

${ }^{133}$ Como ejemplifican las declaraciones de Sánchez Bella, ministro de Información y Turismo, "para el autor que no actúa correctamente no pueden existir ni teatros oficiales, ni créditos, ni premios del cine o del espectáculo; para el empresario o productor que respalde o ayude a
} 
máxima herramienta fue la categoría de 'Interés Nacional', creada el 15 de junio de 1944, otorgable a aquellas películas "que contengan muestras inequívocas de exaltación de valores raciales o de enseñanzas de nuestros principios morales y políticos ${ }^{134 "}$ (Art. 3). Un distintivo que desde el principio creaba una jerarquía en la producción cinematográfica del período y, derivado de ello, una red clientelar.

La intervención estatal en el sector cinematográfico consistió en dos líneas de actuación. Una primera de ayudas económicas a la producción vinculadas en origen a permisos de importación y doblaje que generarían el monto necesario para sufragar los costos del proyecto audiovisual. Un sistema que en 1952 se redefinió en relación con el coste previsto de la película además de su catalogación por la Junta de Clasificación en función a su calidad. Sin embargo, la falta de criterios estables en el dictamen de las resoluciones de la Junta derivó en la dependencia de la misma respecto a las preferencias y juicios de los integrantes de las comisiones de valoración, fomentando el favoritismo y con ello la complacencia gubernamental. Principalmente existían dos líneas de subvención económica. La primera de ellas emanaba del Servicio de Ordenación Económica responsable de otorgar una de las seis categorías por las que se clasificaba la calidad de cada película y que comportaba la concesión de un porcentaje económico sobre el coste previsto del proyecto ${ }^{135}$. La de 'Interés Nacional' recibiría el $50 \%$ de subvención, la de primera A el $40 \%$, primera B el $35 \%$, segunda A el $30 \%$ y segunda B el $25 \%$ $y$, finalmente, las películas clasificadas de tercera ${ }^{136}$ no optaban a subvención $^{137}$. La segunda línea de protección económica adquirió forma de

\footnotetext{
directores o ayudantes de dirección o guionistas enemigos no puede haber ninguna clase de subvención". Reproducido en Gómez, 1990: 317.

${ }_{134}$ Reproducido en Gubern, 1981: 79.

${ }^{135}$ En 1956 ante la práctica de inflado de los costes previstos de los proyectos el Estado estableció el techo de subvención en los tres millones de pesetas. En 1961 se acordó conceder una ayuda complementaria de hasta un $20 \%$ extra para la categoría primera A y hasta un $10 \%$ para la segunda $A$.

${ }^{136}$ Pronto las categorías de segunda B y de tercera fueron despojadas de la subvención prohibiéndose además el estreno de esta última en las salas de Madrid y Barcelona.

${ }^{137}$ Entre 1953 y 196132 películas fueron clasificadas de 'Interés Nacional', otras 127 entraron en la categoría primera A, 169 en la primera B, 178 en la segunda A y 81 en la segunda B. Gubern et alii, 2009: 252.
} 
crédito sindical ${ }^{138}$, un mecanismo que dejó de funcionar en 1956 debido a la preferencia de los productores por las subvenciones sobre la obra terminada.

Al crédito sindical se suman otras medidas complementarias centradas en la regulación de la distribución y promoción exterior de las películas nacionales que suponen la segunda vía de intervención estatal en el ámbito cinematográfico. Entre ellas, las licencias de doblaje concedidas como premio a la producción. En 1951 se introdujo el sistema de contingencias que regulaba el volumen de títulos importados por un mismo país. Y en $1955 \mathrm{se}$ creó la cuota de distribución ${ }^{139}$ a la vez que se mantenía la cuota de pantalla ${ }^{140}$, ambas con el fin de garantizar la exhibición de cine nacional.

En conclusión, se trataba de un sistema económico de subvención que García Escudero cuestionaba por cuanto que:

"El régimen de permisos de importación, concedidos como primas a la producción nacional, convertía ésta, de fin, en medio para obtener los codiciados permisos. Se desviaba así al cine del mercado, con lo cual se hacía innecesaria la constitución de productoras fuertes, con planes para años, y se estimulaba, sin quererlo, la aventura financiera del productor de una sola película. Ese clima de especulación alejó del cine a muchos de sus posibles colaboradores solventes, económica o intelectualmente ${ }^{141 "}$.

Ante la creciente actividad coproductora el Estado intentó regular, por medio de orden ministerial, el régimen de concesión de los permisos de rodaje y establecer las características necesarias para considerar la

\footnotetext{
${ }^{138}$ El crédito sindical se convirtió en cinematográfico en 1958, regulado y se financiaba por el Banco de Crédito Industrial. Consistía en un préstamo de hasta el $60 \%$ del presupuesto del proyecto ampliable un $5 \%$ más si la productora podía justificar una actividad de tres películas por año y ejercía las funciones de distribución. En el caso de poseer estudios de rodaje el monto ascendía hasta el 70\%. En cifras suponían 733.222 pesetas de media en 1956 y de 1.294.500 en 1954. Cantidades importantes teniendo en cuenta que el promedio de un proyecto oscilaba los 3.600.000. Heredero, 1993: 79.

${ }_{139} \mathrm{La}$ cual en los años de guerra comercial con la MPAA revirtió contra el cine español al extenderse la consideración peyorativa de ser un impuesto nacionalista a pagar por el derecho a exhibir la pujante cinematografía norteamericana.

${ }^{140}$ En 1953 esta era de una película nacional por cada seis extranjeras, subiendo al 5 por 1 en 1958 debido al incremento de la producción nacional, siempre dependiendo de la época del año y del tipo de sala.

${ }^{141}$ García, 1954: 12-20.
} 
condición de coproducción creándose para tal fin el Sindicato Nacional del Espectáculo, S.N.E y el Grupo Sindical de Producción de Uniespaña en 1959.

En definitiva un conjunto de órdenes y organismos creados por el régimen franquista para construir un sistema de protección estatal que prolongase la vida de una industria cinematográfica nacional escasa de capitales propios por lo que, a pesar de todo, la mayor urgencia hubiese sido desvincular la producción de la importación "para que el productor tuviera que volver hacia su natural fuente de ingresos: el mercado ${ }^{142 " . ~ U n a ~ c i r c u n s t a n c i a ~ a ~ l a ~ q u e ~ s e ~}$ suma la contradicción que suponía financiar un cine nacional a través del dinero de la importación "de las películas que más daño hacen a nuestra producción", denunciaba García Escudero.

\subsection{Las políticas de García Escudero}

La década de los años cuarenta terminó con una industria cinematográfica subsidiaria de las ayudas económicas del Estado y sometida al control jurídico y moral del régimen y de la Iglesia católica. Unas circunstancias que no hacían más que acrecentar la debilidad ${ }^{143}$ de una industria que "en vez de asumir el tímido reto de potenciación de la calidad [iba] a preferir mantener la dinámica de clientelismo y chanchullo, donde la consideración ${ }^{144}$ cultural del cine era excepcional y donde siempre predominaba la doctrina del beneficio

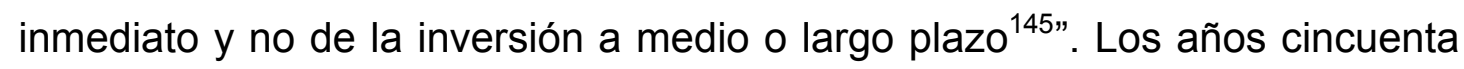
iniciaron con ciertas perspectivas de mejora como demuestran las cuarenta y ocho películas estrenadas en 1950, una cifra que aumentaría hasta los noventa y un títulos en 1961. El promedio de estrenos nacionales se situó en

\footnotetext{
142 Ibídem.

${ }^{143}$ Heredero habla de una "vida artificial de una industria que, pese a consolidar una cierta infraestructura y gozar del favor popular, deja al descubierto su extrema debilidad". Monterde et alii, 1996: 196.

${ }^{144}$ Una falta de consideración hacia el cine como forma cultural debido, entre otros, al desdén e ironía con que algunos de los intelectuales de la época se refirieron al medio. Un hecho denunciado en la editorial número 2 de la revista Objetivo de enero de 1954.

${ }^{145}$ Monterde et alii, 1996: 255.
} 
setenta títulos a lo largo del lustro, en comparación a los cincuenta y dos títulos de 1942, la más alta producción de la década de los cuarenta.

Las circunstancias político-económicas, abordadas anteriormente, enfrentaron dos maneras de entender la supervivencia del régimen franquista entre los sectores inmovilistas y los tecnócratas católico-liberales. No solo se produjeron tensiones por el control del aparato del régimen, sino también se desarrollaron una serie de contradicciones ya patentes desde la creación del Ministerio de Información y Turismo "cuya funcionalidad persigue simultáneamente- ofrecer una (falsa) imagen de apertura y mantener el aparato interno de propaganda a salvo de tentaciones liberalizadoras ${ }^{146 " . ~ U n a ~}$ interpretación basada en la colisión real entre Gabriel Arias Salgado, el primer titular del citado ministerio perteneciente al sector integrista, y el titular de la Dirección General de Cinematografía y Teatro, José María García Escudero, comprometido con la consolidación y competitividad del sector. Dos dirigentes que ilustran dos vías desde las que se entendió la gestión del sector cinematográfico.

García Escudero fue uno de los nombres destacados en el ámbito cultural español de la España de los años 50. Su trayectoria ensayística sobre temas culturales y especialmente cinematográficos lo hizo valedor del cargo de director general de cinematografía y le erigió como una de las figuras clave del cine español del momento. En 1955 participó -desde su cargo político e institucional- en el I Congreso Nacional de Cinematografía de Salamanca con una ponencia en que defendía la reconexión con el realismo como vía para la resignificación del cine español ${ }^{147}$. La visión de García Escudero se basaba en la renovación de las estructuras cinematográficas:

\footnotetext{
146 Ídem: 203.

147 García Escudero mantuvo una actividad ensayística en torno al estado y necesidades del cine español y de la vida cultural en general. Un ejemplo es el artículo "Cine y vida moderna". Y que dice así: "La maravilla que el cine pudo ser se nos ha convertido en este grosero, banal, mecanizado mecanismo para entontecer a esas muchedumbres que una, dos o tres veces por semana, se sepulta en las salas de proyección para absorber con concupiscencia casi pecaminosa el gran estupefaciente que le hará olvidarse por unas horas lo que es y le arrebatará el tiempo que necesitaría para saber qué debe ser". En Arriba, 17-marzo-1950.
} 
"Centradas en el mantenimiento y racionalización de las ayudas a la producción, vinculándolas a una mayor calidad, pero también clarificando el mercado interior mediante el análisis de los costes de producción y la incidencia del doblaje, los déficits de la distribución del cine nacional y de la exportación, la declaración de intransferibilidad de los permisos de importación... ${ }^{148 " .}$.

Desde su prolífica faceta como ensayista destaca su análisis del estado de la producción cinematográfica nacional desde la perspectiva artística, económica y administrativa. En Los problemas del cine español I y $\mid I^{149}$ se reúne una serie de artículos publicados en la revista Objetivo a lo largo de 1954 y que fundamentarían su intervención en Las Conversaciones de Salamanca. Teniendo en cuenta el elocuente título del compendio, García Escudero señalaba los riesgos de la censura vigente desde el convencimiento de su necesidad o la protección estatal contemplando el criterio temático para la adjudicación de las ayudas. Defensor de la incorporación de las generaciones universitarias a las profesiones del sector, también propuso diferentes vías para incrementar -o activar- la rentabilidad de las inversiones económicas en el cine, atendiendo al mercado exterior, la cuota de distribución y al doblaje. En cuanto a la protección estatal, propuso su limitación para que nunca llegase a cubrir el coste total de las películas, a la vez que abogaba por la intransferibilidad de los permisos y la desvinculación de la producción y de la importación. Medidas planteadas con el objetivo de acabar con la sistematización fraudulenta con que se concebía el negocio del cine en detrimento de su consideración artística, cultural y su consolidación industrial. Finalmente, en cuanto a las fórmulas de gestión administrativa, García Escudero apostaba por la unificación de los trámites necesarios para la consecución de un proyecto, hasta el momento dificultados por la cantidad de ministerios y demás organismos estatales implicados en la gestión de la industria cinematográfica.

García Escudero ostentó en dos ocasiones el cargo de director general de cinematografía. En 1952 tuvo lugar una gran crisis al otorgar la categoría de

\footnotetext{
${ }_{148}$ Gubern et alii, 1995: 247.

${ }^{149}$ Artículos publicados en los números 2 y 3 de la revista Objetivo, enero y mayo de 1954.
} 
'Interés Nacional' a la película Surcos, de José Antonio Nieves Conde en perjuicio del título de Juan de Orduña, Alba de América. La de Nieves Conde era una película cuestionaba temas incómodos para el régimen como eran el éxodo rural, los problemas de adaptación al medio urbano y determinados aspectos morales. Muchos quisieron ver en ella cierta voluntad neorrealista al abordar los problemas sociales de la España de la época, para lo cual su realizador, de perfil falangista, tensaba los bordes de lo decible. Una osadía que García Escudero entendió con la firme voluntad de otorgar a Surcos la citada distinción a costa del último trabajo de Juan de Orduña, un realizador centrado en la explotación del cine histórico. No obstante, la resolución le costó su dimisión. Unos hechos que, desde una perspectiva historiográfica, abrían una grieta en el corsé del intervencionismo cinematográfico estatal.

Sin embargo, antes de su destitución García Escudero había tenido tiempo de idear un plan estratégico para la dinamización de todos los apartados del sector cinematográfico. Entre las medidas principales destacan las primas a la exportación de películas nacionales ligadas al incentivo de su competitividad en el mercado extranjero. Para ello se creó en 1959 Uniespaña, siguiendo el modelo de Unifrance y Unitalia, conglomerado gestionado por el Sindicato Nacional del Espectáculo,

\subsection{La industria cinematográfica nacional ${ }^{150}$}

\subsubsection{Tejido productor}

Iniciados los años cincuenta, y con la decadencia de Cifesa, la estructura de la industria cinematográfica española se basaba en una red de productoras de tamaño medio y pequeño. Debido a la falta de interés de la banca privada fueron las propias empresas del sector ${ }^{151}$ quienes invertían en

\footnotetext{
${ }^{150}$ España era la sexta industria a mediados del siglo $\mathrm{XX}$ por detrás de Francia, Gran Bretaña, Italia, Alemania Occidental y la Unión Soviética. Heredero, 1993: 80.

${ }^{151}$ Nacía el fenómeno de realizadores metidos a productores: Juan de Orduña fundó Orduña Films en 1941, Sáenz de Heredia junto a su hermano creó Chápalo Films en 1944 y Ana Mariscal estaba al frente de Bosco Films en 1952. Manuel Mur Oti fundaba Celta Films en
} 
la producción, siendo en muchos de los casos para proyectos concretos con la rápida desaparición de la empresa lo que evidenciaba la falta de planes a medio o largo plazo ${ }^{152}$, eran las llamadas productoras de una sola película. Esta práctica escondía una concepción mercantilista de la obra cinematográfica que, aprovechando el sistema de protección estatal, terminó por descapitalizar una posible estructura empresarial. Un hábito oportunista, efímero y corrupto para la constitución de un tejido industrial estable y competitivo, por lo que resulta difícil referirse a la cinematografía española en términos de industria propiamente dicha.

Llegados a mediados del siglo XX las deficiencias descritas contribuyeron a la falta de sentido del oficio del cine. Unos hechos que el cineasta y teórico Ricardo Muñoz Suay ${ }^{153}$ denunciaba alertado por la falta de interés y compromiso de los técnicos del sector, además de la carencia formativa que les impedía desarrollar una mínima conciencia profesional. Esta situación se relacionaba con la falta de una estructura industrial estable que mantuviese regularmente unos cuadros profesionales, propiciando por el contrario la competencia desleal entre trabajadores. Pero este era un problema que la protección del Estado no iba a solucionar puesto que dependía de la propia industria. En definitiva, esta fue una de las demandas de la editorial número dos de la revista cinematográfica Objetivo ${ }^{154}$ de enero de 1954, en los preámbulos de las Conversaciones de Salamanca. La línea editorial de la

1953; Rafael Gil dirigió Coral P.C desde 1955, Antonio del Amo creó Argos S.L. en 1956 y Apolo Films en 1960 y Ladislao Vadja fue el presidente de Halco P.C.

${ }^{152}$ A partir del análisis de los datos recabados por Carlos F. Heredero (1993: 78) de los Anuarios del Cine Español publicados por el Sindicato Nacional del Espectáculo en 1956 y 1962, se concluye que entre 1951 y 1954 se registraron cincuenta y cuatro empresas productoras, y durante el tramo 1955-1961 otras ciento cuarenta. De entre las cuales ciento setenta y seis solo tuvieron actividad durante una película. En porcentajes se traduce en un $66,6 \%$ en 1950 que aumenta hasta el $69,4 \%$ en 1955 y al $72,5 \%$ en 1960 . Desde la perspectiva de las empresas con más actividad -que superan las diez películas en el período 1951-1961- destaca Suevia Films con un promedio de 4,2 películas por año, I.F.I con un 3,7, y Benito Perojo con un 3,1.

${ }^{153}$ En su artículo "Nuestro cine necesita: Oficio". En Índice, núm. 68-69, octubre-noviembre de 1953.

154 "El cine no constituye en España una verdadera profesión, aunque para muchos pueda ser un medio de vida. Es necesario el sentido del oficio, casi de lo artesano, pues sólo de esta forma podrá formarse el indispensable espíritu de colaboración". Editorial de Objetivo, núm. 2, enero de 1954. 
publicación se explica posteriormente a raíz de su participación en el encuentro salmantino.

Hubo un grupo de productoras que consiguieron desarrollar una actividad significativa en la década de los años cincuenta. La protagonista absoluta del sector en la década anterior había sido CIFESA, la empresa valenciana de los hermanos Casanova creada con el objetivo de implantar en territorio nacional el sistema de estudios hollywoodiense. Pero el modelo empresarial de CIFESA entró por segunda vez en crisis ${ }^{155}$ en 1952 concluyendo su etapa de producción directa. Un factor determinante para su quiebra fue la caducidad de títulos que comprendieron el llamado ciclo histórico, fuente principal del éxito de la productora. Es cierto que en la segunda mitad de los años cuarenta este tipo de películas había gozado del favor del régimen llegando a considerarse la más valiosa "expresión audiovisual del franquismo de posguerra ${ }^{156 "}$. Sin embargo, como ejemplo del impacto de la esfera política en la cultural, el viraje diplomático hacia los Estados Unidos introdujo nuevos modelos cinematográficos reclamando nuevas fórmulas audiovisuales. Para entonces las fórmulas de la productora valenciana chocaban frontalmente con el proyecto franquista de modernización del país. La adversidad que portaba la nueva década se evidenció con el fracaso en taquilla ${ }^{157}$ de los estrenos de $1951^{158}$. Un revés comercial que se hizo más patente al no recibir las calificaciones previstas por parte de la administración franquista, las cuales debían aportar los porcentajes económicos necesarios para la cobertura de los costes de producción. Tal fue el caso de Alba de América de Juan de Orduña, nacida a instancias de Carrero Blanco y bajo el amparo del propio Instituto de Cultura Hispánica. A pesar del respaldo desde

\footnotetext{
155 Véase Fanés, 1982: 223.

${ }^{156}$ Heredero, 1993: 88.

${ }^{157}$ Entendido no en cifras de recaudación sino en tiempo de permanencia en cartel, ya que no existen los registros de taquilla de la época, solo exiguos datos de tiempo de exhibición en salas, como más adelante se explica. Por ejemplo La leona de Castilla aguantó 63 días y Alba de América 53.

${ }^{158}$ Ocaso ratificado con los fracasos comerciales de Una cubana en España declarada de tercera categoría -lo que suponía su no exportación; La leona de Castilla clasificada en la categoría 2a; Alba de América, o Lola la Piconera pese a recibir la $1^{\mathrm{a}}$ categoría. Clasificaciones insuficientes para hacer frente a las altas cifras desembolsadas por CIFESA. A lo que cabe sumar la suspensión del rodaje de Teresa de Jesús por desavenencias con la administración.
} 
las instancias del régimen, la película no consiguió la calificación de 'Interés Nacional', como se ha argumentado anteriormente.

Más allá del caso de Alba de América, la trayectoria de la productora CIFESA ejemplifica la imprudente gestión de las ayudas estatales tomadas como fuente principal de financiación. En cualquier caso, la empresa prolongó su vida hasta 1956 a través de una producción encubierta ${ }^{159}$. Resulta interesante el paralelismo que Heredero traza entre el final de la productora valenciana y la coyuntura política. Fue también durante el verano de 1956 cuando se produjo el traspaso de poder de falangistas a tecnócratas del Opus Dei, un punto de inflexión que daba inicio a una nueva estrategia diplomática hacia el exterior pero con repercusiones significativas en el interior del país, como se ha visto.

En lo referente al sector del audiovisual, los ecos llegaron en forma de cambio de preferencias. Mientras que los falangistas se mostraban más "interesados en controlar una poderosa infraestructura de distribución, los tecnócratas se decantaban por el saneamiento económico y la liquidación de una vieja herencia de posguerra ${ }^{160 " . ~ E l ~ a n a c r o ́ n i c o ~ p e r i p l o ~ d e ~ C I F E S A ~}$ consiguió alcanzar el año 1964 en calidad de distribuidora ${ }^{161}$, tiempo suficiente para cosechar su último gran éxito popular, El último cuplé de Juan de Orduña, 1957. La prolongación de la vida de CIFESA ${ }^{162}$ evidenció el deambular de una empresa erigida en ejemplo de la dependencia de la protección jurídico-económica del Estado, "puntual expresión de un arco temporal en el que [...] se produce una fuerte convulsión que afecta tanto a la superficie como a las entrañas de la España amamantada por el franquismo ${ }^{163 "}$.

\footnotetext{
${ }^{159}$ Entre los proyectos de esta nueva etapa se encuentran La hermana San Sulpicio, Los ojos dejan huellas de 1952, o El beso de Judas y Cañas y barro, ambas de 1954.

${ }_{160}$ Heredero, 1993: 92.

${ }^{161}$ La suma de películas que gestionó ascendía a 137 títulos en el período entre 1955 y 1964.

${ }^{162}$ CIFESA escenifica su coda con la coproducción Vampiresas 1930 de Jesús Franco y la distribución de Las hijas del Cid de Miguel Iglesias, ambas de 1962.

${ }^{163}$ Heredero, 1993: 92.
} 
Agotado el modelo clásico de superproducción de CIFESA y Emisora Films, surgía un nuevo modelo que contemplaba pocos gastos fijos debido a la colaboración con otras productoras lo que permitía la diversificación de los proyectos y la incursión en el sector de la distribución. Surgía una segunda ola de compañías que dejaban atrás la producción de películas en serie y la contratación en nómina de actores y actrices como había sucedido con la asociación de Amparo Rivelles y Aurora Bautista con la malograda CIFESA. El nuevo modelo industrial contemporáneo se regiría por las necesidades del proyecto concreto planteado como "una organización de los equipos técnicos, artísticos y de producción pensados ad hoc ${ }^{164 " . ~ E s t a ~ f u e ~ l a ~ b a s e ~ e s t r u c t u r a l ~}$ del éxito de Suevia Films, modelo de productora vinculado a la distribución. La andadura de Suevia se remonta a 1940 año en que Cesáreo González la fundó emprendiendo el negocio de la distribución en $1947^{165}$. IFI Films, creada en 1949 por Ignacio F. Iquino, fue otra de las productoras de esta nueva remesa de empresas. Asentada en Barcelona su actividad se centró en la "serie B" al no alcanzar sus películas excesiva repercusión comercial a excepción de El Judas dirigida por el propio Iquino en 1952. La cifra de películas salidas de IFI Films alcanzó los 41 títulos, solo por detrás de Suevia Films. Finalmente, IFI junto a la productora de los hermanos Balcázar -con control sobre la distribuidora Filmax y líder en la producción de westerns, representaba el sector de producción catalana frente a la concentración de la actividad en Madrid.

\footnotetext{
${ }^{164}$ Vicente J. Benet. "Tipologías del estrellato durante el franquismo: algunas fórmulas dominantes". En de Lucas; Elduque, 2017: 33.

${ }^{165}$ Aunque Ramón Torrado y Antonio del Amo son los dos realizadores que más colaboraron con Suevia, la productora participó en títulos tan variados como Muerte de un ciclista, 1955, Calle Mayor, 1956 o La venganza, 1958 de Juan Antonio Bardem. En los dramas La Laguna Negra de Arturo Ruiz-Castillo, 1952 y Fedra de Manuel Mur Oti, 1956. En las películas folclóricas La estrella de Sierra Morena de Ramón Torrado, 1952, Morena Clara de Luis Lucia, 1952, llegando al nuevo género musical del cuplé con La reina de Chantecler de Rafael Gil, 1962 y al cine con niño cantor en El ruiseñor de las cumbres de Antonio del Amo, 1958. Suevia Films fue la responsable del descubrimiento de Joselito dentro de la ola de nuevas actrices-cantantes entre las que se encontraban Lola Flores, Carmen Sevilla o Paquita Rico.
} 
Respecto al resto de empresas que compusieron el tejido productor de la década, los historiadores del cine Monterde y Arocena ${ }^{166}$ coinciden en diferenciar tres ejes de actividad. Los dos primeros corresponden a las líneas dominantes del cine español que, salvando las particularidades de cada proyecto, contaron generalmente con el favor del régimen lo que favoreció la proliferación de películas de temática religiosa y también de la llamada nueva comedia española. La temática religiosa interesó a un buen número de productoras. A veces sin vinculación directa con la Iglesia católica como fue Aspa Films, creada en 1950 por Vicente Escrivá, aunque si representaba los intereses eclesiásticos como muestra el papel protagónico de sus personajes: el misionero católico de Balarrasa de Nieves Conde, 1951; la cantante convertida en novicia de Sor Intrépida de Rafael Gil, 1952; o el cura mediador de La guerra de Dios también de Gil, 1953. Títulos que consiguieron el respaldo del régimen a través de la concesión de la categoría de 'Interés Nacional', como síntoma del momento político en que los intereses del Estado se vinculaban a los eclesiásticos.

Otra de las empresas interesadas en temáticas religiosas fue Ariel Films, creada en 1951, detrás de títulos como Los jueves milagro de Luis G. Berlanga, 1957; Jeromín de Luis Lucía, 1953, o Esa voz es una mina también de Lucía, 1955. En otros casos la temática religiosa se debía a la vinculación directa de la productora con la Iglesia católica. Cercano al Opus Dei José Carreras Planas creó Pecsa, empresa catalana que obtuvo un gran éxito con ¿Dónde vas Alfonso XII? de Luis Cesar Amadori, 1958. Y de la estrecha vinculación con los sectores católicos nació en 1958 Procusa S. A. la cual, como Pecsa, se dedicó principalmente a las coproducciones, destacando los éxitos con Italia de Los últimos días de Pompeya de Mario Bonnard, 1959, y El Coloso de Rodas de Sergio Leone, 1960. Finalmente cabe apuntar que tras el estímulo crítico de las Conversaciones de Salamanca estas dos productoras fueron tachadas por "la derecha salmantina"167.

\footnotetext{
${ }^{166}$ En sus respectivos trabajos José Enrique Monterde "Continuismo y disidencia (19511962)". En Gubern et alii, 1995: 239-293 y Carmen Arocena "Luces y sombras. Los largos años cincuenta (1951-1962)". En Castro et alii, 2005: 70-129.

${ }^{167}$ Hernández; Revuelta, 1976: 45.
} 
El segundo eje de actividad identificado por Heredero y Arocena lo constituyen aquellas productoras centradas en "la nueva comedia española introductora de los postulados que iban a cimentar el cine del desarrollismo de los sesenta ${ }^{168 " . ~ A s t u r i a s ~ F i l m s ~ f u e ~ f u n d a d a ~ e n ~} 1953$ por Pedró Masó y Rafael J. Salvia quien dirigió ¡Aquí hay petróleo!, 1955, y Las chicas de la Cruz Roja, 1958, título emblemático de la tendencia de comedia de parejas. Por su parte Ágata Films estaba presidida por José Luis Dibildos y Pedro Lazaga y representaba la línea costumbrista dentro de la comedia del desarrollismo con los títulos Viaje de novios de León Klimovsky, 1956 y Los tramposos de Pedro Lazaga, 1959. Y aunque cosechase sus mayores éxitos en la década de los sesenta, es conveniente mencionar a Hesperia Films como el último componente de la tríada de productoras de la nueva comedia española con títulos como Tres de la Cruz Roja de Fernando Palacios, 1961, Atraco a las tres de José María Forqué, 1962, o Historias de la televisión de José Luis Sáenz de Heredia, 1965.

El tercer, y último, eje de productoras nacionales activas en este momento lo conforman aquellas empresas que se apartaron de las dinámicas dominantes -en cuanto a narrativa y/o estructura- ofreciendo un cine comprometido con la realidad social. Entre las más relevantes se encuentran Altamira S.L., Atenea Films, Uninci y Films 59. Altamira fue creada en 1949 por Juan Antonio Bardem, Luis G. Berlanga y Eduardo Ducay a los que se sumó Ricardo Muñoz Suay. La actividad de la productora dio comienzo con Día tras día de Antonio del Amo, 1951, y Esa pareja feliz del tándem BardemBerlanga, 1953. El vínculo de los fundadores de Altamira con el Instituto de Innovaciones y Experiencias Cinematográficas, "una escuela que era vista con defensivo y hostil corporativismo por los estamentos profundos del cine español” ${ }^{169}$, propició su cierre en 1955, trasladándose sus integrantes a Uninci, fundada en 1949 bajo la dirección del franquista Alberto Reig. Uninci fue la responsable de dos de los éxitos más importantes del cine español de mediados del siglo XX Bienvenido Mr. Marshall de Luis G. Berlanga, 1952 y Viridiana de Luis Buñuel, 1961. Bardem realizó con esta productora Sonatas,

\footnotetext{
${ }^{168}$ Gubern et alii, 1995: 259.

${ }^{169}$ Borau, 1998: 53-54.
} 
1959 y A las cinco de la tarde, 1960. En esta productora también se gestó, aunque no se llevó a cabo el proyecto de Cesare Zavattini, Luis G. Berlanga y Ricardo Muñoz Sua, Cinco historias de España, al que se dedica un apartado posteriormente. Finalmente, cabe citar Atenea Films, responsable de Surcos de Nieves Conde, 1951 y coproductora de Amanecer en Puerta Oscura, de José María Forqué, 1957. Y Films 59, dirigida por Pere Portabella que debutaría con Los golfos de Carlos Saura, 1959.

Además de estas empresas hubo nombres propios que produjeron algunos de los títulos más importantes del cine español de esta década como Manuel Goyanes que participó en Muerte de un ciclista, 1955, Calle Mayor, 1956, y La venganza, 1957, de Juan Antonio Bardem. Y Alfredo Matas que a través de Jet Films produjo Plácido de Luis G. Berlanga, 1961. O productoras menores como Documento Films y Época Films responsables de las películas de Marco Ferreri El pisito, 1958, y Los chicos, 1959.

Como herencia del sistema autárquico la industria nacional padecía un grave atraso respecto a las cinematografías europeas y hollywoodiense. Al margen del tejido productor descrito la situación cotidiana de la industria cinematográfica española que afrontaba su día a día bajo restricciones eléctricas, escasez de celuloide ${ }^{170}$, material y cámaras anticuadas; además de una extendida dependencia de sus profesionales de los estudios de rodaje. Mientras las cinematografías mundiales perfeccionaban los sistemas de color, de definición de imagen, de sonido o experimentaban sobre nuevos formatos $^{171}$, la española rodaba en diferentes estudios con tal de aprovechar decorados usados y ahorrar en gastos. Una situación que se mejoraría, relativamente, con la llegada de las coproducciones, de significativos avances

\footnotetext{
${ }^{170}$ Como paradigma del intervencionismo del Estado el cupo de película virgen era suministrado por el Ministerio de Industria siendo, generalmente, insuficiente para terminar el rodaje en óptimas condiciones lo que obligaba a recurrir al celuloide de contrabando. llustrativas sobre la escasez de celuloide son las declaraciones de la realizadora Ana Mariscal a propósito de Segundo López, aventurero urbano de1952: "Hacía poco se había estrenado Ladrón de Bicicletas, de Vittorio de Sica, de la que se destacaba el hecho de haber sido producida con muy pocos medios. De Sica empleó 40.000 metros de negativo y yo utilicé 8.000". En el coloquio Una mirada al cine español. Años 50 celebrado en Zaragoza en marzo de 1990.

${ }^{171}$ Es el momento de los nuevos formatos: Cinemascope y el Technirama; el sistema Panavisión y Vistavisión o la alta fidelidad en el campo del sonido.
} 
técnicos y el intercambio de nuevos modos de entender la práctica cinematográfica.

\subsubsection{El mercado norteamericano}

El proteccionismo estatal, como se ha argumentado, condicionó el desarrollo de la industria cinematografía nacional y propició prácticas fraudulentas por parte de unos productores que recurrían al hinchado de los costos estimados con el objetivo de obtener la mayor cantidad de subvención posible. ${ }^{172}$ Una coyuntura descrita por el productor José Luis Dibildos:

"[Una industria] que no buscaba al público y vivía de la clasificación (con ésta solía amortizarse el $70 \%$ del costo y en algunas películas el $100 \%)$, un cine que se producía para llevarse un pellizco de la ayuda estatal, que no servía para la exportación, que no servía para el público español, que no tenía afán de calidad ni de sinceridad"173.

Prácticas denunciadas en numerosas ocasiones por aquellos que si tenían un interés real por desarrollar la industria nacional y veían en las productoras de una sola película la constatación de una actitud especulativa de empresarios sin escrúpulos ${ }^{174}$.

Ante la insostenibilidad de la industria nacional por sus propios medios, Pérez Bowie y González García opinan que:

"La clave económica del sistema radicaba en que fuese el dinero extranjero el que financiase la industria española [...] a través de unas tasas directas cuyas reinyección en el aparato productivo español se encargaba de gestionar el Sindicato Nacional del Espectáculo [y] por medio de las ganancias que las propias productoras conseguían de la

\footnotetext{
${ }^{172}$ El falseamiento de los presupuestos resultaba una práctica común que la administración intentó combatir con la publicación en julio de 1952 de las Normas de Protección y Regulación por las que se establecía una tabla de clasificación mediante la cual la D.G. de Cinematografía adjudicaría el porcentaje de protección sobre el coste estimado del proyecto. ${ }^{173}$ Hernández; Revuelta, 1976: 39.

${ }^{174}$ Y que García Escudero (1954) tachaba de "especuladores, agiotistas, fabricantes de permisos de importación, pedigüeños de las mil y una ayudas, los del cine como negocio..., pero negocio de una sola película".
} 
venta de licencias de importación a las productoras o distribuidoras extranjeras que querían exhibir sus productos en España ${ }^{175 "}$.

La presencia del capital extranjero permite a estos autores hablar del paso de un mercado cautivo, en relación a la censura jurídico-moral ejercida por el régimen, a un mercado vigilado. El influjo del mercado extranjero mayoritariamente norteamericano- supuso otra importante traba para el desarrollo de la industria nacional en el aspecto económico, y también estilístico, al tomarse el norteamericano como meta en términos de exportabilidad ${ }^{176}$ de la producción nacional. El mercado extranjero desarrolló en el interior de España un negocio de tráfico de permisos de importación y doblaje contribuyendo a la adulteración del funcionamiento financiero de la industria. Esta incidencia revelaba una segunda dependencia de la industria nacional a través de las licencias de importación, vía de ingresos determinada por la clasificación de las películas establecidas por las Juntas de Clasificación y Censura. En conclusión, el negocio del cine en esta década se encontraba, principalmente, en los ingresos de las licencias de importación, lo que sumado al falseamiento de los costes estimados para solicitar los créditos cinematográficos, potenció el fraude ${ }^{177}$.

En 1951, en plena regulación del sistema de licencias, la Motion Pictures Association of America, MPAA, declaró el boicot a la industria española denunciando el abusivo precio de estos permisos. El entonces D.G. de Cinematografía, García Escudero, alcanzó un acuerdo con el lobby norteamericano en que las licencias de doblaje seguían en manos de los productores, ahora con un precio tasado, y se regulaba la importación de películas americanas y los precios a pagar por sus respectivos permisos, lo

\footnotetext{
175 Pérez; González, 2010: 38.

${ }^{176}$ El afán exportador ya planeaba sobre la producción nacional desde la década de los 30 como describe Benet a propósito del caso de la actriz Imperio Argentina que, proveniente de la escena artística, cosechó un gran éxito en pantalla previa asimilación iconográfica de cierto carácter cosmopolita que la conectara con tendencias internacionales, y así hacer exportable una película como Morena Clara de Florián Rey, 1936. De Lucas; Elduque, 2017: 29.

${ }^{177}$ La falta de atención por la explotación de las películas llegaba al extremo de, una vez recuperados los costes de producción, despreocuparse por la comercialización posterior del filme, tampoco existía una preocupación por la demanda real de los productos puesto que que antes se tenía en consideración a los miembros de las Juntas censoras que a los espectadores.
} 
cual ayudaría a combatir su libre especulación en el interior del país. Sin embargo, la situación de desventaja de la industria nacional frente a la norteamericana propició una nueva serie de medidas que contrarrestaron tal desequilibrio a la vez que incrementaron su competitividad en mercados extranjeros. En 1955 se creó una cuota de distribución para asegurar la inclusión de películas nacionales en el monto de películas extranjeras exhibidas, entre las que primaba la producción americana. Como dato, en 1953 de cada seis títulos extranjeros uno debía ser español, llegando a los cinco por cada uno en 1958. No obstante, en el verano de 1955 caducó el acuerdo con la MPAA de enero de 1952 y, ante las restricciones que suponía la cuota de distribución española para el cine norteamericano ${ }^{178}$, las majors iniciaron un segundo boicot al mercado español que duró hasta marzo de 1958.

Durante los años de guerra comercial descendió la presencia de películas americanas $^{179}$. Una situación ventajosa para la industria española que inició la actividad de coproducción con otros países, aunque inaceptable desde la perspectiva americana que veía peligrar su posición hegemónica en el mercado español. La guerra comercial llegó a su fin $\mathrm{y}$, aunque pronto se restableció el dominio americano, supuso el reforzamiento de la red distribuidora española que ahora controlaba la compra del 83\% de las películas americanas frente al $17 \%$ de sus propias distribuidoras. Una situación que daba lugar a nuevos intereses entre la industria americana y la pujante distribución española. Sin embargo, como alerta Heredero (1993), de dicha situación se desprende una lectura negativa desde la perspectiva española, y es que ante el negocio del cine americano, las distribuidoras nacionales parecían más interesadas en este mercado que en su propio cine. La desvinculación de los intereses entre distribuidoras y productoras abría entonces una nueva etapa en el tejido industrial nacional.

\footnotetext{
${ }^{178} \mathrm{Y}$ en concreto la disminución del número de películas para importar de 100 a 80; la obligación de distribuir una película española por cada cuatro dobladas; el aumento del canon de doblaje en películas importadas y la exigencia de distribuir películas españolas en Estados Unidos. Heredero, 1993: 95.

${ }^{179}$ Heredero alerta sobre la consideración peyorativa del cine español como "impuesto nacionalista", una carga a asumir con tal de llevar a cabo el negocio del cine americano. Monterde et alii, 1996: 206.
} 


\subsubsection{La exhibición nacional}

Partiendo de la inexistencia de un control de taquilla, registros de recaudaciones, estructuras salarias ni cualquier dato económico del período 1950-1959 resulta imposible analizar con certeza el éxito comercial del cine español de esta década. Resta atenerse a los registros de permanencia en cartel de las películas en los locales de estreno, aunque solamente de Madrid. Unos datos de los que se concluye que los tres grandes éxitos de la década de los cincuenta fueron El último cuplé de Juan de Orduña, 1957, en cartel durante 325 días; ¿Dónde vas Alfonso XII? de Luís César Amadori, 1959, con proyecciones en dos cines y un total de 399 días y La violetera, de Amadori que estuvo en salas 217 días. Unos exiguos datos que alcanzan para constatar el encumbramiento de la actriz Sara Montiel y, con ella, del cuplé lo que ejemplifica un nuevo modelo de estrellato nacional que Benet define como "fórmula icónica estable ${ }^{180 "}$ basada en la centralidad del cuerpo de la actriz protagonista. Una fórmula que, vinculada directamente con la tradición del cine clásico norteamericano en que actrices como Marilyn Monroe o Ava Gardner ejercían como agente cohesionador de un proyecto, resultó significativa del estrellato cinematográfico español de los años 50.

También aparecen en la tabla reproducida por José Enrique Monterde algunos de los títulos de cine rural de la década de los cincuenta ${ }^{181}$. Un caballero andaluz, de Luis Lucia y El ruiseñor de las cumbres permanecieron en cartel 56 días. Mientras que Bienvenido Mr. Marshall de Luis G. Berlanga y La guerra de Dios de Rafael Gil alcanzaron los 51 días. La presencia en este listado sugiere su contabilización entre las películas de más éxito de la década, a pesar de la gran distancia respecto a los títulos de mayor éxito. Finalmente cabe apuntar que Condenados estuvo en cartel durante 14 días y Cañas y barro durante 16 días laborales y 4 festivos. Sin embargo, más allá de la aceptación del público, para un análisis óptimo se precisa determinar la rentabilidad y el alcance de explotación de estas películas por mucho que fuesen un gran éxito de taquilla en la capital española en un momento,

\footnotetext{
180 De Lucas; Elduque, 2017: 29.

${ }^{181}$ En Gubern et alii, 1995: 262.
} 
precisamente, de aumento del número de salas en un $90 \%{ }^{182}$ a finales de la década debido a un cúmulo de factores como el escaso desarrollo de la televisión, el coste asequible de las entradas de cine o la falta de oferta de ocio popular.

\subsubsection{La coproducción cinematográfica}

Mientras a nivel político y económico la España de los años 50 se preparaba para una lenta apertura hacia el exterior, en el marco europeo, desde que Italia y Francia estableciesen en 1949 un pacto de producción conjunta, empezaron a firmarse acuerdos bilaterales que en temas cinematográficos favorecerían la aparición de "un mayor número de películas en color, disposición de mejores recursos técnicos y equipos más grandes y complejos, así como la posibilidad de contratar a estrellas internacionales ${ }^{183}$ ". Desde la perspectiva española, el nuevo panorama diplomático favoreció la actividad coproductora ${ }^{184}$ que a nivel nacional permitió no solo la colaboración con cinematografías extranjeras ${ }^{185}$ sino también la promoción del cine nacional en el exterior. El retraso sistemático español quedó plasmado en la tardanza con que se firmaron los convenios de colaboración con Italia y Francia, o el reconocimiento de pleno derecho de la actividad coproductora con su correspondiente acceso a las subvenciones estatales en marzo y mayo de 1953, respectivamente.

La coproducción supuso un importante revulsivo para la industria española ${ }^{186}$ en términos de mejora de la capacitación técnica de los

\footnotetext{
${ }^{182}$ Y que seguirá en aumento hasta las 8.193 salas en 1966, momento de colapso y consiguiente retroceso del mercado de la exhibición cinematográfica en salas.

${ }^{183}$ Pérez; González, 2010: 40.

${ }^{184}$ Y que supuso el 34,2\% de la producción total en 1957. Monterde et alii, 1996: 208.

185 Una vez más el gobierno franquista intercedió en la regulación de la actividad coproductora dictando en 1953 una orden ministerial por la que se dictaba el régimen de concesiones de permisos de rodaje para las coproducciones así como las condiciones requeridas para ser aceptadas como tal. Gubern et alii, 1995: 254.

${ }^{186}$ Según el cuadro de Heredero, desde que en 1953 se reconociese la legitimidad de la actividad coproductora, las películas fruto de colaboración entre países supusieron un tercio de la producción total, llegando a constituir la mitad del total durante los años de boicot de la MPAA. Del los 47 títulos de 195310 son coproducciones, en 1954 lo son 16 de 69; en 1955
} 
profesionales y de cierta apertura temática. También favoreció la pluralidad de los gustos del público. $Y$ a su vez se requería al cine español llegar al público internacional lo cual afectaba directamente a la rigidez censora. EI fenómeno de la coproducción también tuvo una repercusión significativa a nivel político y social al favorecer las relaciones internacionales de un régimen dictatorial preocupado por vigilar el más mínimo atisbo de cuestionamiento de sus postulados. Finalmente, el choque del sistema proteccionista español con las estructuras más desarrolladas del resto de países con los que se establecía colaboración comportó cierta deslegitimación de los sistemas censores franquistas al verse estos obligados a ampliar los límites de lo decible de cara a la opinión internacional. Un choque que también reveló el doble rasero de los dictámenes censores del régimen, más permisivos con las obras extranjeras.

Finalmente, un aspecto negativo del auge de la coproducción fue la picaresca de las empresas españolas a la hora de atribuirse el estatus de coproductoras por el hecho de gestionar la distribución de una película. En este caso la práctica fraudulenta del clientelismo volvió a planear sobre el campo de la coproducción, cuya repercusión llegó a las Conversaciones de Salamanca, desde donde se hizo una llamada a la regulación de las coproducciones para asegurar la efectiva ampliación del mercado español.

\subsection{Nuevas fórmulas para una cinematografía nacional}

Del mismo modo que sucediese en el ámbito diplomático y en el juego de equilibrios internos del régimen, también en el espacio cinematográfico empezaban a abrirse fisuras cuestionadoras. El Neorrealismo fue un modelo crítico que llegó de Italia erigido en referente cultural y político para los nuevos realizadores europeos que "concebían el cine como algo distinto de lo que entonces se hacía en el país ${ }^{187 " . ~ E l ~ N e o r r e a l i s m o ~ i t a l i a n o ~ c o n s t i t u i ́ a, ~ p a r a ~}$

\footnotetext{
15 de $61 ; 23$ de 77 en 1956; 26 de 76 en 1957; 25 de 72 en 1958; 17 de 68 en 1959 y 16 de 71 en 1960. Heredero, 1993: 435.

${ }^{187}$ Monterde; Torreiro, 1987: 42.
} 
ciertos cineastas y críticos españoles, el revulsivo para emprender la ansiada superación de los modelos hegemónicos de representación y de estructura industrial vigente.

El Neorrealismo había surgido de la coyuntura de la posguerra tras la caída del fascismo italiano. En cambio, en la España autárquica de 1945, el contexto político no dejaba margen a la contestación directa o de ruptura significativa. Además, la industria cinematográfica se regia por unas fórmulas complacientes para con el régimen ya que este era, a su vez, el pulmón económico de la industria. Razones elementales por las que resulta complejo abordar la asimilación del modelo neorrealista italiano en el contexto español. Sin embargo, el punto de confluencia surge del afán de ambas cinematografías por superar el trauma de la guerra, la asfixia política, la crisis económica $y$, en definitiva, de declive de sus respectivas sociedades. Finalmente, fue en el viraje de la vida española de los años cincuenta donde empezó la gestación del embrión resistente que posteriormente derivaría en la "cultura del realismo" y/o "cultura de la disidencia [aquella] enfrentada a la pobreza y la falsedad del arte oficial ${ }^{188 "}$.

"Las condiciones de conocimiento del Neorrealismo en España no fueron especialmente idóneas. Tardío, incompleto, parcial, desordenado, desfigurado... sin embargo, el Neorrealismo llegó a España para, según siempre se ha dicho, ofrecerse como ejemplo del camino que no debía tomar el cine español para unos, como modelo e impulso regeneracionistas según otros ${ }^{189 " .}$.

Para la historiografía la influencia del Neorrealismo en el cine español plantea dificultades por diversas razones. La primera se refiere a la escasa presencia de títulos del Neorrealismo italiano en el circuito comercial nacional al tratarse de un tipo de cine con una importante carga dramática y social ${ }^{190}$. Los títulos exhibidos fueron los más humanistas en detrimento de los más

\footnotetext{
${ }^{188}$ Heredero, 1993: 288.

189 Nieto; Company, 2006: 55.

190 Solo los largometrajes de Vittorio De Sica Ladri di biciclette, 1948; Miracolo a Milano, 1951; Stazione Termini 1952 y II tetto 1956 se estrenaron puntualmente en las pantallas españolas.
} 
comprometidos, como demuestra el postergado estreno en salas españolas de La terra trema de Luchino Visconti (1948) en 1967 o de Roma, citta aperta de Roberto Rossellini (1945) en 1969. La segunda razón tiene que ver con la limitación de su acceso casi siempre fuera del circuito comercial. Sintomático al respecto fue el planteamiento de las dos Semanas de Cine Italiano organizadas por el Instituto Italiano de Cultura en Madrid en $1951^{191}$ y $1953^{192}$. Unos encuentros de acceso restringido en que se proyectaron las películas Cronaca di un amore de Antonioni, 1950, Umberto $D$ de De Sica, 1951, o Bellissima de Visconti, 1951. También se limitaron a cineastas y críticos los pases organizados por el Instituto Italiano de Cultura en Madrid y Barcelona en que se proyectó además de Umberto $D$ y Bellissima, Non c'è pace tra gli ulivi de Giuseppe De Santis, 1950 y Germania anno zero de Roberto Rossellini, 1947. En definitiva, y como constata Heredero, la exhibición comercial del cine neorrealista italiano en territorio español, al menos en la década de los cincuenta, no existió.

El panorama de exhibición del cine neorrealista no impidió su repercusión en la primera promoción de estudiantes del Instituto de Innovaciones y Experiencias Cinematográficas. Entre los alumnos llamados a revitalizar el cine nacional se encontraban Ricardo Muñoz Suay, Luis G. Berlanga, Juan Antonio Bardem, Francisco Canet, Eduardo Ducay o Paulino Garagorri, los cuales tuvieron probado contacto con Vittorio De Sica, Luigi Zampa o Cesare Zavattini, algunos de los artífices del Neorrealismo italiano. De hecho la amistad de este último con Ricardo Muñoz Suay y Luis G. Berlanga se materializó en los proyectos El gran festival y Cinco historias de España. En

\footnotetext{
${ }^{191}$ Esta primera organizada a instancias de Giuseppe Cardillo, subdirector del mencionado Instituto y apoyadas por Unitalia. Se celebró entre el 14 y el 21 de noviembre de 1951 y permitió la proyección de Cronaca di un amore además de Ė primavera de R. Castellani, 1949. Según explica Monterde el grupo de afortunados que pudo ver las secuencias finales de la ópera prima de Federico Fellini Luci di varietà, 1950 y Paisà de Roberto Rossellini, 1946 fue aún más reducido.

${ }^{192}$ La segunda Semana de Cine Italiano se celebró entre el 2 y el 9 de marzo de 1953 a instancias del Instituto Italiano de Cultura, Unitalia y de Anica. Este segundo encuentro fue importante porque permitió el contacto directo con las personalidades más relevantes del Neorrealismo italiano: Zavattini, De Sica, Emmer, Lattuada, Carla del Poggio, Andreotti o Lo Duca visitaron España. Además de la proyección, previa invitación, de /l camino de la speranza, Due soldi di speranza, Processo alla città de L. Zampa, 1952, Il cappotto de A. Lattuada, 1952. Y el pase privado de Ossessione de L. Visconti, 1942, y Paisà de R. Rossellini, 1946.
} 
definitiva, un contacto que desde la perspectiva española sirvió para situar a este cine italiano como un posible modelo estético.

No obstante, pese al contacto entre cinematografías, debido a las particularidades de España descritas:

"El abordaje directo de la realidad se desvela imposible. El análisis de la problemática social se sustituye por la resolución humanitaria de casos individuales, la dureza y las aristas del retrato son desplazadas por la edulcoración sentimental, la denuncia de las estructuras deja paso a la asimilación y recuperación de los descarriados. La negación oficial de la realidad y la censura de cualquier hipotético testimonio social, toma de conciencia o perspectiva transformadora impiden [...] la implicación de las imágenes en una realidad hecha fílmicamente contigua y por tanto en una directriz tendente a llenar la distancia referencial $^{193 "}$.

Por todo ello, el fermento contestatario nacional, de haberlas, debía adoptar formas de aproximación a la realidad tangenciales o metafóricas.

Otro factor que obstaculizó la reformulación de la industria cinematográfica nacional en la vertiente que lo hizo el Neorrealismo en Italia surgió de la heterogeneidad de puntos de vista de los profesionales del medio a la hora de plantear posibles vías de desarrollo. Desde el sector franquista surgieron posicionamientos reticentes a la asimilación de unas fórmulas internacionales por suponer que harían peligrar la 'españolidad' de la producción nacional. El debate generado desde actitudes de autodefensa acerca del influjo extranjerizante versó en torno a "la escasa originalidad del Neorrealismo, su carácter forzado por las circunstancias posbélicas, su rápido agotamiento al constituirse en una fórmula, la incomprensión de la enorme variedad dada dentro del propio Neorrealismo, la limitación del movimiento a un "ismo" más y como tal perecedero, como un "producto de circunstancias" en palabras del realizador Antonio Momplet o como un suplemento de la "parte canalla"

\footnotetext{
${ }^{193}$ Monterde: El neorrealismo en España. Tendencias realistas en el cine español. Tesis doctoral inédita. Barcelona, Junio 1992. Fragmento reproducido en Heredero, 1993: 290.
} 
añadida al realismo, en opinión de Arturo Ruiz-Castillo ${ }^{194}$. Por su parte, los profesionales más receptivos a nuevas fórmulas de expresión -principalmente sectores de izquierda reunidos en torno a las revistas Objetivo y Cinema Universitario, defendían la importancia del Neorrealismo desde su compromiso social, su función como testimonio del presente y como estímulo de la conciencia crítica. Argumentos que lo erigían en referente para una renovación de la cinematografía española que pasase por una reconexión con las tradiciones realistas del arte español, entendidas como ejemplo de resistencia cultural en el seno de la intelectualidad nacional.

\subsubsection{El Neorrealismo como referente para el cine español}

La imposibilidad de un Neorrealismo español en los términos y condiciones del italiano no impidió situarlo como detonante para una reformulación de la vida cultural española que, desde su especificidad, comprendería cierta conexión con la tradición realista anterior. Todo ello, cabe recordar, en un contexto europeo predispuesto al cambio encabezado por unas generaciones jóvenes que, amparadas en el transcurso del tiempo, se distanciaban del trauma de la guerra para reivindicar oportunidades de desarrollo personal "de [búsqueda de] nuevas fuentes de ilusión, nuevos maestros y nuevos modelos sociales [y] la necesidad de superar la dialéctica capitalismo-comunismo ${ }^{195 " . ~}$ Italia era el país más próximo a España debido a que ambos estaban experimentando la evolución social de la penuria de posguerra al desarrollismo económico que comportaría la aparición de "nuevas revistas, [...] grupos y asociaciones de carácter cultural y [donde verdaderamente] se desarrolla un gran interés por el cine, la literatura y el arte más nuevos ${ }^{196 " . ~}$

Uno de los primeros que abordó la cuestión del Neorrealismo en España fue José E. Monterde. En su tesis doctoral establecía una serie de bloques

\footnotetext{
194 Nieto; Company, 2006: 56.

195 Gracia; Ruiz, 2011: 223.

${ }^{196}$ Crainz, 1998: 40.
} 
para entender las diversas facetas del Neorrealismo en el contexto español: "El Neorrealismo como moda coyuntural, el Neorrealismo como modelo regeneracionista, el Neorrealismo como dialéctico punto de partida hacia las formas de la modernidad cinematográfica en su versión española ${ }^{197 " . ~ E l ~}$ primero se refería a la asimilación superficial de las formas estéticas neorrealistas por parte de un cine nacional fuertemente arraigado en los esquemas más conservadores de la tradición creativa española. De donde, justamente, procedía el escepticismo hacia un cine cuyo realismo tachaban de miserabilista, pesimista, tremendista y amargo ${ }^{198}$. Como ejemplo de esta actitud el realizador Nieves Conde declaraba en el transcurso de una entrevista: "Hablemos ahora de la técnica y el estilo, y, por Dios, que no se nos olvide aludir al neorrealismo, si no queremos pasar por fósiles ${ }^{199 " . ~}$

El segundo suponía cierto grado de asimilación de las fórmulas del Neorrealismo como modelo regeneracionista, del cual la primera promoción del IIEC junto a los responsables de las revistas Objetivo y Cinema Universitario, serían sus principales valedores. De hecho las inquietudes que despertaba este nuevo cine se materializarían en el encuentro de las I Conversaciones Cinematográficas de Salamanca de 1955 aunando a "los sectores del falangismo crítico o del catolicismo menos ultramontano [junto a] los liberales orteguianos o los sedicentes y amansados filocomunistas ${ }^{200 "}$ en términos de Ferrando y Company. $\mathrm{Y}$, finalmente, el tercer bloque referido a aquellas actitudes $\mathrm{y}$ líneas de pensamientos que entendieron las fórmulas del Neorrealismo como modelo a superar para terminar eclosionando en el Nuevo Cine Español, como paradigma de un cine propio.

\footnotetext{
${ }^{197}$ Nieto; Company, 2006: 58.

${ }^{198}$ Este conjunto de opiniones revela la falta de conocimiento para su fundamentación pues el panorama de destrucción de posguerra, la pobreza o los problemas juveniles son temáticas presentes en los filmes neorrealistas por la misma razón que los directores como Rosellini, De Sica, Zavattini o Visconti descienden a pie de calle en busca del sustrato verídico para sus narraciones. No obstante el cine neorrealista que discierne entre la vía del objetivismo y de la crítica abarca temas contemporáneos y también históricos; otros de cariz satírico o cómico.

${ }_{199}$ Declaraciones que forman parte de la entrevista a José Antonio Nieves Conde publicada en Primer Plano, núm. 540, febrero 1951.

${ }^{200}$ Nieto; Company, 2006: 58.
} 
Más allá de las diferentes vías de rechazo, asimilación o superación de las fórmulas del Neorrealismo, el hecho más significativo en el marco de esta argumentación es la constitución de este cine como impulso para la revelación de actitudes cuestionadoras y comprometidas con el devenir de la industria cinematográfica nacional. Una vertiente que discurrió en torno a las relecturas de la tradición regeneracionista y noventayochista en busca de referentes identitarios nacionales. La consigna de la primera editorial de Cinema Universitario ilustra la convergencia de estos movimientos, "Nunca es tarde en España para rescatar el sepulcro de Don Quijote ${ }^{201}$ ". Aunque la publicación tuviese una repercusión limitada en el seno de la cultura española del momento, la proclama de Cinema Universitario se sumaba a la propuesta de Muñoz Suay de acudir a la tradición realista que fundamentó la obra de la Generación del 98. Como sucedió durante crisis finisecular la transformación de la década de los años cincuenta XX motivó la revisión de la tradición representativa que encerraba huellas de significado del ente 'España', una coincidencia que se analizará posteriormente.

Esta idea no solo se planteaba desde los sectores más progresistas de izquierda, nombres de diferentes adscripciones políticas e ideológicas coincidían en situar la tradición realista nacional como vía para la supervivencia del cine español. En esos años Cinema Universitario ${ }^{202}$ publicaba el lamento de Bardem ante la insuficiencia de un cine que no llegaba a ser testimonio de su contemporaneidad. La segunda editorial de Objetivo $^{203}$ denunciaba la ineficacia de un cine ensimismado y carente de problemas y García Escudero, desde su doble perfil político y comprometido con la cultura ${ }^{204}$, publicaba sus análisis razonados sobre el estado de la cinematografía nacional ${ }^{205}$. Una heterogeneidad de puntos de vista que cristalizó en las Conversaciones de Salamanca.

\footnotetext{
201 Cinema Universitario. Núm.1. Enero-Marzo de 1955.

${ }^{202}$ Bardem decía así "el cine será ante todo testimonio o no será nada". En Cinema Universitario. Núm.4, diciembre de 1954.

${ }^{203}$ Objetivo. Núm. 2, enero de 1954.

${ }^{204}$ Como constatan sus publicaciones en la sección 'Tiempo' en Arriba, su colaboración con el Cine-club el SEU de Salamanca y sus cuantiosas reflexiones sobre el cine español desde perspectivas políticas, económicas y conceptuales.

${ }^{205}$ 'Los problemas del cine español I y II' fueron publicados en los números 2 y 3 de la revista Objetivo. Enero y mayo de 1954.
} 


\subsubsection{EI IIEC y el cine español}

El Instituto de Innovaciones y Experiencias Cinematográficas -IIEC- fue el espacio clave en la gestación de un nuevo sentir sobre el devenir de la cinematografía nacional. EI IIEC fue creado por orden ministerial de 1947. Dependiente del Ministerio de Educación Nacional y con sede en la Escuela de Ingenieros Industriales, su andadura se remonta a 1941 cuando su primer director, Victoriano López García, dirigía unos cursos de cine en la Escuela de Ingenieros Industriales. La primera plantilla de profesores, de gran heterogeneidad ideológica, la compusieron Carlos Serrano de Osma (19161984), Luis Marquina (1904-1980), Carlos Fernández Cuenca (1904-1977), José Camón Aznar (1898-1979) y Antonio del Amo (1911-1991).

La aparición del IIEC contribuyó significativamente a la consideración de la industria cinematográfica como algo más que mera forma de entretenimiento dando lugar al "nacimiento de su comprensión por algunos como una forma de cultura y un frente de combate que reproducía el enfrentamiento entre el aún predominante oficialismo y una incipiente disidencia ${ }^{206 " . ~ E n ~ s u ~ t r a y e c t o r i a ~}$ el IIEC tuvo que hacer frente a numerosas adversidades que sumían su día a día en condiciones de penuria. Entre los avatares Heredero remarca la invalidez del diploma oficial de la escuela por parte del Sindicato Nacional del Espectáculo lo que imposibilitaba para la práctica profesional, además de numerosos problemas derivados de la gestión de los locales y el mobiliario de la Escuela. En definitiva la nueva ola de cineastas 'no oficialistas' era acogida con reticencias ${ }^{207}$ por parte de una industria anclada en sus fórmulas acomodaticias. Como ejemplo destaca el hecho que hasta el momento la

\footnotetext{
${ }^{206}$ Gubern et alii, 2009: 245.

${ }^{207}$ Reticencias provenientes de todos los sectores empezando por el político franquista, pasando por el industrial y terminando en el propio cinematográfico donde los realizadores en activo veían con cierto recelo el proyecto de los regeneracionistas del IIEC abiertamente declarado en contra de las fórmulas existentes. Sintetizaba la situación el cineasta José Luis Borau en declaraciones a Antonio Castro: "Entre la profesión había una desconfianza absoluta hacia aquella gente que quería hacer algo tan diferente. Por otro lado [...] estaba la postura de la gente de la Escuela de hacer un cine de espaldas a la industria. Así salían películas que desde un punto de vista eran más interesantes que el cine industrial español, y desde otro estaban mucho peor hechas y eran mucho más toscas. Total, que desde el punto de vista de la industria los chicos de la escuela no eran solamente unos seres impertinentes y peligrosos por su mentalidad, sino que hacían cosas que el público rechazaba". Castro, 1974: 98.
} 
dinámica de aprendizaje de los profesionales del cine español había sido la práctica en los propios estudios de rodaje. A pesar de la falta de receptividad general en 1951 lograba licenciarse la primera promoción de estudiantes del IIEC formada por Juan Antonio Bardem, Luis G. Berlanga, Eduardo Ducay (1927-2016), Paulino Garagorri (1916-2007), José Gutiérrez Maesso (19202016), Miguel Martín y Florentino Soria (1917-2015). Una generación de nuevos cineastas con formación académica, en un contexto en que "la Universidad española, vieja y oficial, no quiere saber nada todavía con las nuevas formas de expresión, aunque sean tan importantes como la cinematografía 208 ", denunciaba Basilio Martín Patino durante las Conversaciones de Salamanca.

La primera promoción del IIEC supuso una importante transgresión en el perfil de los directores españoles, ahora existía un espíritu de colaboración al consolidarse el sentido de oficio del que hasta entonces carecía la profesión del cine, una cuestión abordada en la segunda editorial de la revista Objetivo ${ }^{209}$.

Finalmente, el revulsivo que supuso esta generación de realizadores con formación académica se concretó en el sentir contestatario de una generación que hacía uso de la institución universitaria para canalizar sus inquietudes. Este grupo de jóvenes realizadores, como definía Monterde, entendió el Neorrealismo como modelo para un actualización cinematográfico autóctono, puesto en marcha en proyectos como las nuevas productoras Altamira y UNINCI, la programación de cine-clubs, la revitalización de la revista cultural Índice o la creación de Objetivo, "una instancia teórica y

\footnotetext{
${ }^{208}$ Proclama de Martín Patino plasmada en 'Palabras Inaugurales de las Primeras Conversaciones cinematográficas Nacionales'. A partir del resumen publicado en Objetivo. Núm.6, junio de 1955. Y de la que ya se hacía eco Muñoz Suay en su análisis pormenorizado de las necesidades del cine español. Sobre la falta de atención del ente universitario se refirió en 'Nuestro cine necesita otras normas'. En Índice. Núm.53, julio de 1952.

${ }^{209}$ El texto de la editorial dice así, "salvo en casos contados y raros, el cine no constituye en España una verdadera profesión, aunque para muchos pueda ser un medio de vida. Es necesario el sentido del oficio, casi de lo artesano, pues solo de esta forma podrá formarse el indispensable espíritu de colaboración. Esta falta de profesionalidad, que es una grave falta de vocación, no puede remediarla un IIEC apenas dotado de lo elemental". 'El cine español'. En Objetivo, núm.2, enero de 1954.
} 
especializada de notoria trascendencia ${ }^{210 " . ~ E n ~ d e f i n i t i v a ~ u n a ~ a c t i v i d a d ~ q u e ~}$ constituiría la antesala del inminente encuentro salmantino.

A falta de un nutrido grupo de títulos representativos de este nuevo sentir, la valía de esta generación llamada a regenerar ${ }^{211}$ las fórmulas del cine español quedó manifiesta en los éxitos de Bienvenido Mr. Marshall de Luis G. Berlanga, 1952 y Esa pareja feliz de Juan Antonio Bardem y Berlanga, 1953. Esta última se publicitada en la editorial del número 76 de Índice de enero de 1955 en los siguientes términos:

"Un tema puramente cinematográfico y hondamente español. El estar tratado el tema con un aire de pura comedia no le quitaba un ápice de profundidad. Las influencias, porque las tenía, eran influencias sanas del mejor cine de Chaplin o René Clair, vertidas en un matraz nacional, que las transformaba en sujetos auténticos de vida española".

La película de Bardem y Berlanga era deudora de la asimilación autóctona de las fórmulas del Neorrealismo italiano a la par que heredera de las referencias culturales nacionales. Dos lecturas para una misma obra que advierten sobre la ramificación que emprenderá la cinematografía de los años cincuenta: una vertiente de carácter popular identificada en las películas de Luis G. Berlanga, Fernando Fernán-Gómez, Rafael Azcona y Marco Ferreri ${ }^{212}$ y que en un giro posterior discurriría hacia el humor negro y el esperpento. $Y$ una segunda que Carlos F. Heredero identifica a partir del género del drama como metáfora y que tiene en la obra de. Bardem su máxima representación ${ }^{213}$. No obstante, como advierte Castro de Paz, cabe tener en cuenta el peligro de concentrar en las figuras de Bardem y Berlanga la actitud

\footnotetext{
${ }^{210}$ Heredero, 1993: 303.

${ }^{211}$ En palabras de Román Gubern, "esta generación, que podría calificarse como 'primera generación cinematográfica universitaria', por su acceso al cine por la vía del estudio académico, se declaró sin ambages como claramente 'regeneracionista' ante los males de un cine español que detestaban". Pérez, 1981: 32-35.

${ }^{212}$ Y los títulos La vida por delante de Fernando Fernán-Gómez, 1958, o El pisito de Marco Ferreri, 1959.

${ }^{213}$ Las obras de Juan Antonio Bardem de los años cincuenta constituyen el preámbulo del Nuevo Cine Español fundamentado, a su vez, en los títulos Novio a la vista de Luis G. Berlanga, Cómicos y Felices Pascuas de Bardem y Todo es posible en Granada de Sáenz de Heredia, todas realizadas en 1954.
} 
regeneracionista vinculada a la influencia del Neorrealismo italiano entendido como disidencia cultural propiamente nacional. Todo ello sin obviar el aliciente que el tándem de realizadores supuso para la regeneración del cine español, analizado por Muñoz Suay ${ }^{214}$ y García Escudero ${ }^{215}$. En todo caso Esa pareja feliz constituía un punto de partida de un sentir crítico. Sus artífices personificaban "la única esperanza cinematográfica, una generación que guarda en la mochila el bagaje de lo nuevo, de lo anti, de la preparación universitaria y de la inteligencia precisas para [suplir] lo profesional con creces $^{216 ”,}$ en opinión de Muñoz Suay. Sin embargo el contexto hostil en que tuvo lugar el proyecto de los alumnos del IIEC evidenció aún más la urgencia de una verdadera renovación. En aquellos años José María Cano Lechuga era el director del centro. Falangista de declarada aversión al encuentro de Salamanca, su ineficiente gestión recibió las críticas de los nuevos alumnos del Instituto, Basilio Martín Patino, Mario Camus, Miguel Picazo, José Luis Borau, Julio Diamante o Joaquín Jordá. La vehemencia con que los alumnos defendieron sus intereses consiguió el reemplazo de Cano Lechuga por José Luis Sáenz de Heredia (1911-1992), perteneciente al grupo de los cineasta oficialistas pero de perfil dialogante centró su gestión en "relanzar [su] capacidad como vivero de nuevos creadores y como ágora del fuerte debate intelectual que se abre paso por sus aulas desde finales de los años cincuenta ${ }^{217 ",}$.

EI IIEC pronto se erigió como referente de resistencia cultural por el debate ideológico y las fórmulas alternativas propuestas, y a la vez conseguía consolidarse en el sector industrial como plataforma para la incorporación en el ámbito profesional. Llegada la década de los sesenta el Instituto mutaba a Escuela Oficial de Cinematografía, EOC, con García Escudero de vuelta en la D.G. de Cinematografía. La Escuela se convertía entonces en el "semillero oficial del protegido Nuevo Cine Español ${ }^{218 " . ~ R e s u l t a ~ i n t e r e s a n t e ~ c o n s t a t a r ~ l a ~}$

\footnotetext{
${ }^{214}$ Véase "Unas afirmaciones”. En Índice. Núm.64, junio de 1953.

${ }^{215}$ En el texto 'El binomio B-B de nuestro cine'. En la sección 'Crítica de cine' de Ateneo, marzo-agosto de 1954, que conformaría La historia del cine español en cien palabras y otros escritos de cine. Cine-club del SEU de Salamanca. García Escudero, 1954: 179-181.

${ }^{216}$ En palabras de Muñoz Suay en 'Unas afirmaciones.' En Índice. Núm.64, junio de 1953.

217 Heredero, 1993: 395.

218 Ídem: 308.
} 
paradoja que supone el IIEC-EOC -puesto que su razón de ser era servir como revulsivo político mediante la reformulación del sistema cinematográfico nacional- en relación a la dependencia estatal. Luis G. Berlanga afirmaba no entender:

\footnotetext{
"Por qué el Régimen creó una escuela de cine a imagen y semejanza del Centro Sperimentale de Roma, que no había sido, precisamente, muy beneficioso para el fascismo italiano. Sin embargo, la administración creó esta Escuela, sabiendo que entre los alumnos no iba a salir ninguna Leni Reifensthal español que hiciera un cine de acuerdo con las necesidades del supuesto aparato ideológico franquista ${ }^{219 "}$.
}

La contradicción señalada por Berlanga encuentra respuesta en los mismos argumentos que justificarían la acogida de las Conversaciones de Salamanca en los confines de la institución universitaria y con el SEU salmantino como valedor. En ambos casos la respuesta se encuentra en la coyuntura interna del propio aparato franquista obligado por el transcurso de los nuevos tiempos a un replanteamiento de sus preceptos fundacionales. Unas circunstancias que en el ámbito cinematográfico tendría su plasmación en la aparición de nuevas sensibilidades más allá del monolitismo oficialista. También se explica por la actividad de miembros del régimen como Joaquín Ruiz-Giménez, Antonio Tovar o José María García Escudero los cuales, desde la competencia de los organismos que dirigían, permitieron el florecimiento de actitudes y formas de pensamiento moderadamente cuestionadoras de las políticas del régimen franquista.

\subsubsection{Las Conversaciones de Salamanca, crisol contestatario}

Para cuando iniciaba la década de los cincuenta Surcos golpeaba desde la conciencia crítica al régimen franquista. También se estrenaron Esa Pareja Feliz y Bienvenido Mr. Marshall. Una tríada de películas que, desde una

${ }^{219}$ Company. "El cine español de posguerra". En Contracampo, núm. 24, 1981. 
perspectiva historiográfica, constataba la configuración de un nuevo sentir basado en la reflexión crítica sobre aspectos de la sociedad del periodo. La aparición del IIEC, de las productoras Altamira y UNINCI, sumada a la actividad de los cine-clubs y de las revistas cinematográficas Objetivo y Cinema Universitario conformó la que Heredero llama "constelación de inquietudes" y Monterde "esfuerzos regeneracionistas ${ }^{220}$ que confluyeron en las Primeras Conversaciones cinematográficas Nacionales que tuvieron lugar en Salamanca entre el 14 y el 19 de mayo de 1955. Un encuentro nacido de:

"Un pacto o alianza 'regeneracionista' entre falangistas, católicos y comunistas preocupados por la inautenticidad del cine español ${ }^{221 ",}$ "compendio y síntesis, altavoz y caja de resonancia para un amplio y pluralista movimiento disidente que trata de dotarse de una alternativa programática ${ }^{222}$.

"El origen de las Conversaciones de Salamanca fue la Semana de Cine Italiano que se celebró en Madrid mientras nosotros éramos todavía alumnos de la Escuela de Cine ${ }^{223 ", ~ c o n t a b a ~ L u i s ~ G . ~ B e r l a n g a ~ a n ̃ o s ~ d e s p u e ́ s . ~ U n a ~}$ declaración que ratifica de nuevo el vínculo de los ejes que componen la tríada: el Neorrealismo como referente, los alumnos del IIEC como agentes y las Conversaciones como escenario. Sin embargo, cabe resaltar que la primera experiencia de debate en torno al cine nacional había sido el I Curso de Estudios Universitarios de Cine, organizado por Basilio Martín Patino en el Cineclub del SEU de Salamanca en marzo de 1954. Martín Patino personificaba la implicación del sector cineclubista en las actitudes contestatarias, aliado a su vez con el sector teórico encabezado por la revista Objetivo.

De nuevo el modelo del encuentro salmantino provenía de Italia. Por un lado las jornadas se idearon siguiendo la estela de los congresos

\footnotetext{
${ }^{220}$ Nieto; Company, 2006: 51.

${ }^{221}$ Román Gubern en Pérez, 1981: 32-35.

222 Heredero, 1993: 347.

223 Gómez, 1990: 166.
} 
neorrealistas celebrados en Perugia, Varesa y Parma ${ }^{224}$, donde había participado Cesare Zavattini y cuya presencia en España sirvió a Muñoz Suay ${ }^{225}$ de motivación para el inminente papel que este jugaría en la gestación de su propuesta regeneracionista del cine español. Y por otro, los dos agentes impulsores del encuentro tomaban como referente, o se vinculaban directamente, con el movimiento neorrealista. El Cine Club del SEU de Salamanca había sido creado en marzo de 1953 siguiendo la estela de los cine-guf italianos de los años treinta, "vivero de posteriores protagonistas del momento neorrealista ${ }^{26 " . ~ M i e n t r a s ~ q u e ~ l a ~ r e v i s t a ~ O b j e t i v o ~}$ lo hacía tomando como modelo Cinema Nuovo, la publicación italiana dirigida por Guido Aristarco, a su vez seguidora de Cinema, la misma revista que en su día publicó los textos antecedentes del Neorrealismo.

El encuentro salmantino se concibió desde su carácter pluralista ${ }^{227}$ atendiendo a la procedencia de sus participantes entre los que había componentes del proyecto regeneracionista, la élite académica del IIEC, representantes de las estructuras industriales, cineastas y dirigentes del aparato franquista. Todos ellos se habían reunido bajo la preocupación común por el estado de la cinematografía española y sus posibles vías de desarrollo. La pluralidad de perfiles coincidía con la premisa del Partido Comunista de España en el objetivo por agrupar a todos aquellos sectores con vocación democrática y contrarios a los postulados oficialistas. En definitiva, el encuentro permitió el debate sobre el estado de la industria

\footnotetext{
${ }^{224}$ El congreso de Perugia tuvo lugar entre el 24 y 25 de septiembre de 1949 y el de Parma entre el 3 y el 5 de diciembre de 1953.

${ }^{225}$ Es interesante tener en cuenta la editorial "Destinazione Spagna" publicada en el número 33 de Cinema Nuovo, 15 de febrero de 1954, en que se proponía la idoneidad de España como continuadora de los preceptos neorrealistas, por lo que en cierta manera desde la perspectiva italiana si hubo interés por España.

${ }^{226}$ Monterde en Nieto; Company, 2006: 51.

${ }^{227}$ Así lo corroboraría la nómina de asistentes e instituciones participantes. Las revistas Objetivo, Índice, Signo, Ínsula, Alcalá, Ateneo y Otro cine. Los críticos cinematográficos Manuel Villegas López, Luis Gómez Mesa y Juan Cobos. Los profesionales del sector Francisco Canet, Carlos Serrano de Osma, Antonio del Amo, Antonio Román, Rafael Romero Marchent y Fernando Delgado. Los productores Eduardo Manzanos y José Luis Dibildos. Los alumnos del IIEC Julio Diamante o César Santos Fontenla. Los profesores Gutiérrez Maesso, Juan Julio Baena, Lázaro Carreter, Enrique Tierno Galván, Alonso Zamora Vicente y Ernesto Giménez Caballero. Y de las personalidades extranjeras, contando el veto a Zavattini y George Sadoul, Manoel de Oliveira y Jacques Doniol-Valcroze, en representación de Cahiers du Cinéma. Además de Fernando Fernán-Gómez y José Luis Sáenz de Heredia. Fuente Heredero, 1993: 348.
} 
cinematográfica nacional y ofreció a su vez la posibilidad de proyectar el corto documental Douro, faina fluvial de Manoel de Oliveira, 1931, los largometrajes Bienvenido Mr. Marshall de Luis G. Berlanga, Un chapeau de paille d'Italie de René Clair, 1927, Ladri di biciclette de De Sica, 1948 y Muerte de un ciclista de Bardem, 1955, premio FIPRESCI en la novena edición del Festival de Cannes ${ }^{228}$.

El llamamiento del encuentro fue publicado en las páginas del Boletín de las Primeras Conversaciones cinematográficas Nacionales y firmado por los editores de la revista $S_{i g n o}{ }^{229}$. En el texto de la convocatoria Ricardo Muñoz Suay $^{230}$, su máximo responsable, sintetizaba sus ideas respecto al estado de la cinematografía:

\begin{abstract}
"El cine español vive aislado. Aislado no sólo del mundo sino de nuestra propia realidad. Cuando el cine de todos los países concentra su interés en los problemas que la realidad plantea cada día, sirviendo así a una esencial misión de testimonio, el cine español continúa cultivando tópicos conocidos y que en nada responden a nuestra personalidad nacional".
\end{abstract}

Ricardo Muñoz Suay escribió su ponencia adoptando la línea del realismo como única vía para la rehabilitación del cine español el cual, a su vez, se establecía en estrecha relación con "una supuesta identidad nacional aglutinadora de sus propias tradiciones culturales" las cuales abarcaban tanto el "Poema del Mío Cid [como a] La Celestina, El Quijote, Velázquez, Ribera, Goya, Berruguete, Lope de Vega, Rafael Alberti, o Los Bravos de Fernández Santos $^{231}$ ”. Muñoz Suay desarrolló una rigurosa metodología de análisis a lo

\footnotetext{
${ }^{228}$ Para el pesar de los sectores más inmovilistas que insistían en menospreciar los éxitos de la nueva generación concebida como una amenaza para la industria cinematográfica más acomodaticia. Como constata Muñoz Suay en su artículo "Unas afirmaciones". En Índice. Núm. 64, junio de 1953.

${ }^{229}$ Publicado en Cineclub del S.E.U. de Salamanca. Núm. 7. 17 de mayo de 1955. Y también en las revistas Signo. Núm. 788, febrero de 1955 y Cinema Universitario. Núm. 1, marzo 1955. Muñoz Suay estuvo apoyado por los editores de la revista Signo. Basilio Martín Patino, Marcelo Arroita-Jáuregui, Joaquín de Prada, José Pérez Lozano, Juan Antonio Bardem, Paulino Garagorri, Eduardo Ducay y Manuel Rabanal Taylor.

${ }^{230}$ La militancia en el Partido Comunista supuso el veto de Muñoz Suay en el encuentro salmantino siendo sustituido por Manuel Rabanal Taylor.

${ }^{231}$ Heredero, 1993.
} 
largo de su trayectoria ensayística en la revista cinematográfica Índice, entre febrero de 1952 y noviembre de 1953. Desde una perspectiva historiográfica, se le vincula con García Escudero pues ambos se interesaron por analizar todos los agentes implicados en la cuestión cinematográfica a la vez que aportaron estrategias para la implementación del sector.

La preocupación por las cuestiones referidas al cine queda patente en las reflexiones de Muñoz Suay sobre la experiencia del espectador enfrentándose al "hecho o la idea" que se muestra en pantalla, para lo cual el cine debía preocuparse de todos y cada uno de sus espectadores con un "algo que decirir". En opinión del teórico lejos debía quedar "una larga y espesa noche cinematográfica, defendida por los que, con conciencia de lo que hacen, sólo les importa producir films históricos falsos de escayola, films 'patrióticos' de espalda a la realidad nacional, comedietas azucaradas y cursilonas y folklores sucios y malolientes de cine-tomate-color ${ }^{233}$ ". Unas circunstancias que pretendía combatir mediante la reconexión con "la mejor tradición de nuestras artes y nuestras letras como solución a los males de nuestro cine. Tenemos un pasado plástico realista, tenemos un genuino espíritu nacional en nuestras formas de expresión literaria. De ahí debe arrancar nuestro cinema". Para lo cual ofrecía ejemplos concretos animando a "llevar al cine lo que un Ribera y un Goya, lo que un Quevedo y un Mateo Alemán crearon en sus épocas. $Y$ hacerlo nuevo respecto a los problemas de hoy, nuevos ${ }^{234 "}$. Finalmente, Muñoz Suay denunciaba la falta de problemas del cine nacional, en cuanto "que no es ese testigo de nuestro tiempo, que

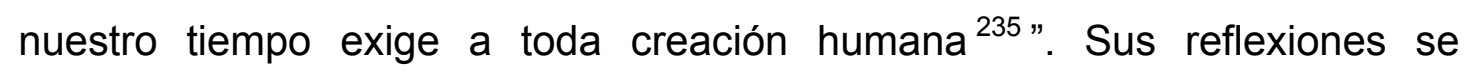
concretaron en los proyectos Festival de Cine y Cinco historias de España, evidenciando el segundo la asimilación de los preceptos del Neorrealismo a través de su relación con Cesar Zavattini, analizados posteriormente.

\footnotetext{
${ }^{232}$ Muñoz Suay describió su preocupación por la experiencia del espectador en "Nuestro cine necesita: Ideas". En Índice. Núm. 48, febrero de 1952.

${ }_{233}$ 'Nuestro cine necesita: Verismo'. En Índice. Núm. 72, febrero de 1954.

${ }^{234}$ Cinema Universitario. Núm.1, marzo de 1955. También publicado en el Boletín de las Primeras Conversaciones cinematográficas Nacionales y en la revista Signo. Núm. 788, febrero de 1955.

${ }^{235}$ El cine español no tenía problemas en el sentido que no afrontaba su realidad circundante como sí hacía el Neorrealismo al plantear las cuestiones sociales y políticas de la Italia de posguerra.
} 
La intervención de García Escudero en el encuentro salmantino también discurrió en la línea del acercamiento a la casuística de la España de los años 50 empezando por la denuncia de la atemporalidad con que las películas abordaban sus argumentos lo que conducía a un falseamiento de la realidad contemporánea. García Escudero en la relectura de los artículos Los problemas del cine español U y II opinaba que "no existían motivos para que un temperamento realista, como el nuestro, no hubiera cuajado en un realismo cinematográfico, para el que estamos mejor dotados que los mismos italianos $^{236 " . ~ A ~ l o ~ l a r g o ~ d e ~ s u ~ t r a y e c t o r i a ~ e n s a y i ́ s t i c a ~ y ~ t e o ́ r i c a ~ e l ~ e l e m e n t o ~}$ 'realismo' fue una constante como demuestra su tesis, "el cine tiene que ser realista, y lo de 'neo' sólo puede significar que el cine iba dejando de ser cine. [...] por realista, el cine tiene que ser agradable y desagradable a la vez porque así es la vida". En respuesta a las posibles consecuencias del movimiento italiano en la cinematografía nacional, García Escudero era partidario de no "decir 'sí' o 'no' al neorrealismo [sino] a las películas en las que el neorrealismo puede aparecer". Una declaración que adquiere forma de llamada a la racionalidad de los juicios de valor más alarmistas vertidos sobre el Neorrealismo desde los sectores menos receptivos. Sobre debate en torno a la cuestión neorrealista en el seno de la cinematografía española, García Escudero apreciaba el valor del movimiento italiano por ser "una producción que ha abierto, más que un capítulo, una época en la historia del cine" y haber encontrado "el secreto del cine italiano [en] la sencillez, la sinceridad, la autenticidad, haber desdeñado un mundo ficticio por el palpitar agridulce de la vida, un cine de evasión por un cine-testimonio, un cine vacío por un cine humano $237 "$.

El productor Eduardo Ducay no acudió al encuentro pero envió su ponencia Caracteres de un cine español ${ }^{238}$. Una reflexión sobre la inexistencia de referencias cinematográficas para la producción nacional de aquel momento en que aprovechaba para reclamar la consideración artística

\footnotetext{
${ }^{236}$ En el texto titulado 'La monserga del neorrealismo'. En la sección Tiempo de la revista Arriba, entre 1951 y 1954 y posteriormente recopilados en Historia en cien palabras del cine español. En Cuadernos del Cineclub de Salamanca, 1954: 65-66.

${ }^{237}$ En el texto 'Cine italiano'. En la sección Tiempo de la revista Arriba. Ídem.

${ }^{238}$ Leída por Muñoz Suay y publicada en Objetivo. Núm.6, junio de 1955.
} 
de la disciplina. Entre sus hipótesis defendía que "el arte es abstracción y síntesis de la realidad", para lo cual tomaba como referentes el Poema del Mío Cid, Los bravos, La Celestina, la novela picaresca o Don Quijote de la Mancha. "Velázquez, Ribera, Goya [...] El alcalde de Zalamea, Fuenteovejuna es igualmente realista, democrático, humano", sentenciaba Ducay partiendo de la idea que "el arte español es nacional, popular y realista, y su riqueza está precisamente en que la realidad se toma como punto de partida". En definitiva, Ducay entendía la realidad como sinónimo de contemporaneidad, para lo cual el cine debía tener una función social, más allá de plasmar debía actuar como agente revelador de la conciencia crítica del espectador.

En otros términos, Basilio Martín Patino también apostaba por la revisitación de la tradición realista nacional como ilustra su argumento: "lo nuevo, ennoblecido por lo viejo, porque es el mismo espíritu de rigor y autenticidad quien los mantiene. Este rigor y esta autenticidad austera de nuestros clásicos ${ }^{239 ",}$ que en cierta medida enlazaba con los postulados de la Generación del 98 sobre la 'casta íntima' en que se abogaba por la construcción de un nuevo corpus referencial teniendo en cuenta la parte histórica "más noble 240 ", en palabras de Laín Entralgo. Fue precisamente Martín Patino, como director del cine-club del SEU de Salamanca, el anfitrión del encuentro cinematográfico y el encargado de leer el discurso de apertura instando al diálogo entre sus participantes para "diagnosticar entre la luz de todos y sin ánimos plañideros, no la realidad de nuestros dolores, sino el posible remedio, más inteligente y práctico ${ }^{241 " .}$

Además de los ya mencionados Bardem, García Escudero y Ricardo Muñoz Suay, la nómina de ponentes la completaron Marcelo Arroita-Jáuregui, José María Pérez Lozano, Juan García Atienza, Juan Julio Baena y Emilio Salcedo -aunque no presente- además de los invitados internacionales Guido Aristarco y Cesare Zavattini. La presencia de Aristarco resultaba

\footnotetext{
${ }^{239}$ Fragmento del discurso reproducido en Ibídem.

${ }^{240}$ Laín Entralgo, 1948: 428.

${ }^{241}$ Fragmento del discurso reproducido en Objetivo. Núm. 6, junio de 1955.
} 
paradigmática puesto que este era el director de la citada Cinema Nuovo de ahí que en su ponencia Notas sobre el realismo ${ }^{242}$ defendiese "un cine más optimista que pueda existir, en defensa de los valores humanos, cristianos y sociales de nuestro tiempo". A diferencia de las trivialidades vertidas sobre el influjo del Neorrealismo en el contexto español, Aristarco insistía en la idea que el modelo neorrealista más allá de centrarse en el retrato de las penurias, la pobreza y la crudeza de la sociedad italiana de posguerra, bajaba a pie de calle para enfrentarse a la realidad circundante sin "miedo de hacer ver las cosas como ellas realmente son. Lava los trapos sucios porque esconder éstos sería como esconder al médico la misma enfermedad, lo cual impediría la salvación para el enfermo". Terminaba su intervención con una entusiasta proclama, "El cine italiano quiere saber, saber, saber, saber, conjugar el pasado y el presente para poder conjugar el futuro de un tiempo mejor ${ }^{243 " . ~}$

La presencia del teórico italiano metafóricamente embriagó a los realizadores ávidos de reconectar el medio cinematográfico con los referentes sociales. Así lo declaraba el propio Arroita-Jáuregui en un artículo en Cinestudio, "todos estábamos borrachos de neorrealismo. Creo que la intención fue derivar nuestro cine hacia el neorrealismo y las sesiones estuvieron cargadas por este movimiento, debido sobre todo a la asistencia de Aristarco 244 ". Por su parte Arroita-Jáuregui, de ideología falangista, presentó la ponencia Obstáculos para un cine español ${ }^{245}$ escrita desde la perspectiva del "espectador responsable" con el fin de demandar "un cine revolucionario, religiosamente exacto, políticamente válido, socialmente educativo y estéticamente valioso", resume Heredero ${ }^{246}$. Desde su particular aproximación a la cuestión también trató la ineducación de los espectadores, la falta de crítica rigurosa y de una política cinematográfica, la desorganización industrial y la mentalidad capitalista consecuencia de la excesiva ayuda económica oficial, concluyendo en la denuncia de la arbitrariedad de los criterios censores.

\footnotetext{
${ }^{242}$ Intervención resumida en el Boletín de las Conversaciones, núm. 8, mayo de 1955 y también en Cinema Universitario. Núm. 2, diciembre de 1955.

${ }^{243}$ Ibídem.

${ }^{244}$ Cinestudio. Núm. 82, febrero de 1970.

${ }^{245}$ También publicada por Objetivo. Núm. 6, junio de 1955.

${ }^{246}$ Heredero, 1993: 350.
} 
Juan Antonio Bardem tituló su intervención Informe sobre la situación actual de nuestra cinematografía ${ }^{247}$ donde plasmó el emblemático pentagrama acerca del cine español que sentenció de "políticamente ineficaz, socialmente falso, intelectualmente ínfimo, estéticamente nulo e industrialmente raquítico". El primero de los dictámenes respondía al intervencionismo estatal que comportaba un 'cine escapista' en forma de explicación virgiliana del éxodo campesino a la ciudad en Surcos o de fantasía en ¡Bienvenido Mr. Marshall!. El segundo surgía por cuanto el cine 'oficial' y conformista vivía de espaldas a la realidad compuesta de "los problemas, las tierras y los hombres de España". Continuaba criticando las posturas despectivas de los intelectuales previos a su generación sobre la cinematografía nacional, culpándoles de sumir en el ostracismo cultural a aquellos verdaderamente interesados en la producción fílmica de los años 50 . También achacaba a la falta de contenido la nulidad estética de las obras resultantes. Y finalmente remarcó la asfixia industrial como consecuencia del férreo proteccionismo estatal.

En la línea de un análisis razonado también discurrió la intervención de García Escudero basada en el compendio de textos Los problemas del cine español I y II, publicados en la revista Objetivo a lo largo de 1954. Analizados anteriormente, resta señalar que, a diferencia de la intervención de Bardem, García Escudero si propuso soluciones concretas a cada uno de los problemas señalados.

Desde la distancia propia a la condición de no profesional del cine se pronunció Emilio Salcedo, periodista interesado a nivel personal en la cinematografía nacional. En su intervención El cine político español ${ }^{248}$ animaba a revalorizar la producción nacional atendiendo al contexto de cambio de los años cincuenta del que había de ser testimonio. Para el autor la manera de conseguirlo consistía en salir en busca de "esos pueblos míseros y [reflejar] su vida en el cine" atendiendo tanto a los "peores" como a los recién creados por el Instituto Nacional de Colonización con el objetivo de

\footnotetext{
${ }^{247}$ Objetivo. Núm. 6, junio de 1955.

${ }^{248}$ Reproducido en Nieto; Company, 2006: 328-332.
} 
"hacer la gran película del campo sobre esta situación, resaltemos el contraste brutal del erial que produce, tierra madrastra, casuchas como pocilgas y la casa y las tierras nuevas...". El periodista era un firme convencido de la necesidad "de hablar del campo, de la transformación de la tierra -pantanos, canales, reparcelaciones, etc.". Unos postulados que en primera instancia eran susceptibles de convergir con el cine de propaganda política del régimen pero que el autor trataba desde los preceptos de construcción identitaria nacional con visos internacionales.

Por su parte Manuel Rabanal Taylor centró su intervención Extensión cinematográfica ${ }^{249}$ en la falta de formación del espectador apostando por los cineclubs como plataforma que aunase a "todas aquellas personas que, aun gustándoles el cine, están al margen de estas manifestaciones intelectuales", además de solicitar su dotación económica, estructura programática y la supresión total de los mecanismos censores. Y José María Pérez Lozano se pronunciaba sobre el estado de la crítica como ilustra el título de su intervención Necesidad de una crítica ${ }^{250}$. Mientras que Juan García Atienza reflexionaba sobre la necesidad de preparación académica de los nuevos profesionales del cine a través del reforzamiento del IIEC en Formación $y$ ejercicio profesional ${ }^{251}$. Y, finalmente, Juan Julio Baena profundizaba en el estado de la producción documental en El cine documental español ${ }^{252}$.

En cuanto al significado e impacto de las conversaciones, estas brindaron la oportunidad de dialogar y debatir por primera vez a un nutrido grupo de personalidades afines o interesadas en la salud del cine español. Teniendo en el horizonte el modelo neorrealista, el cual se pretendía superar a través de fórmulas propias que comportarían la reactivación de la función social y la concreción de una ideología propia para la cinematografía española.

\footnotetext{
${ }^{249}$ Publicada en Objetivo. Núm. 6, junio de 1955.

250 lbídem.

251 Ibídem.

${ }^{252}$ Reproducido en Nieto; Company, 2006: 324-328. Cuya autoría presuntamente se atribuyó Baena, siendo en origen de Eduardo Ducay según nota de los autores.
} 


\subsubsection{Las conclusiones de las Conversaciones de Salamanca}

Hasta la actualidad la trascendencia del informe desalentador de Juan Antonio Bardem ha eclipsado las conclusiones oficiales alcanzadas en los debates de las Conversaciones de Salamanca las cuales definían en los siguientes términos el estado de la cinematografía nacional, "creemos que nuestro cine debe adquirir una personalidad nacional, creando películas que reflejen la situación del hombre español, sus conflictos y su realidad, en épocas pasadas y sobre todo en nuestros días ${ }^{253 "}$.

Desde una perspectiva histiográfica, atendiendo a la heterogénea procedencia de los ponentes, Heredero resalta la ambigüedad con que se redactaron las conclusiones de las jornadas debido, primeramente, a las negociaciones de consenso requeridas para concretar posibles vías de solución. $\mathrm{Y}$ en segundo lugar al hecho que el encuentro gozase de la cobertura gubernamental y el acomodo en las instalaciones de la Universidad de Salamanca. Una aparente contrariedad que, una vez más, se encuentra relacionada con el estado de inflexión del aparato franquista y el nuevo rumbo de la estrategia diplomática del régimen. Brevemente, el Sindicato Estudiantil Universitario se unió al proyecto de Ruiz-Giménez en su etapa al frente de la cartera de educación, 1951-1956, el cual, sin desvincularse de los preceptos franquistas, constituyó la vertiente 'comprensiva' por cuanto veía en la integración de las élites vencidas la vía para la supervivencia del régimen. Ruiz-Giménez constituyó su grupo de trabajo con históricos falangistas desilusionados y por ello sensibles a otras formas de entender la política, entre ellos se encontraba Antonio Tovar que había ocupado el cargo de rector de la Universidad de Salamanca en 1951. Su perfil dialogante justifica la predisposición a albergar en la universidad el encuentro en un momento en que "las universidades españolas se convierten, con sus 'asambleas libres' o sus 'semanas culturales', en una precaria isla de libertad

\footnotetext{
${ }^{253}$ Las conclusiones aprobadas por los ponentes de las Conversaciones de Salamanca fueron íntegramente publicadas en Objetivo. Núm. 6, junio de 1955.
} 
durante el franquismo", tarea que no fue arbitrada ni dirigida, como denunciaba la prensa afín al régimen como El Español ${ }^{254}$.

Retomando el contenido de las conclusiones del encuentro, en el apartado de análisis de los "obstáculos a nuestro cine" se señalaba la "necesidad de que el Estado formule y realice una política congruente con sus auténticos principios y no con los que de su actuación [...] se desprende". También se resaltaba la necesidad de "dar mayor autoridad jurídica al Sindicato del Espectáculo", proponiendo a su vez "una legislación positiva que defienda al autor y al director de la película y la integridad de su obra" en el apartado sobre "el actual derecho cinematográfico español". Se trataba de un análisis detallado del estado de la cinematografía que no profundizaba en las medidas necesarias para implementar las deficiencias señaladas. Sin embargo, el valor del encuentro salmantino, más que en la concreción de sus propuestas, residió en la capacidad de reunión en un mismo espacio del ala de izquierda de mayoría comunista afín a los postulados del realismo y al núcleo católico moderadamente progresista con García Escudero como máximo exponente, la rama liberal del falangismo representada por Marcelo Arroita-Jáuregui y los cineclubs del SEU. Una manifestación de la voluntad de cambio que recogía las denuncias de los sectores menos conformistas de la sociedad. Esta interpretación de la función del encuentro había sido compartida por García Escudero, celebrando en las páginas de Arriba la excepcional oportunidad de diálogo que había tenido lugar, a la vez que reconocía su función como punto de arranque, "eficaz instrumento puesto a

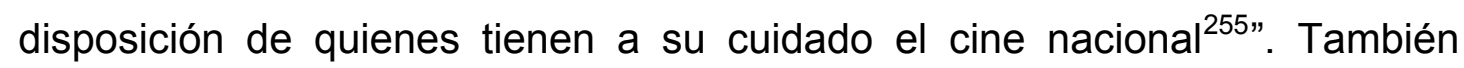
desde las páginas de Objetivo se interpretó el encuentro como la constitución de "un frente nacional cinematográfico, reflejado en esas conclusiones, que [...] fueron aprobadas buscando una base de unidad entre los reunidos ${ }^{256 " . ~}$

Más allá del carácter general de las conclusiones, también hubo espacio para reivindicaciones concretas de las cuales dos se llevaron a cabo en 1962

\footnotetext{
${ }^{254}$ Gracia; Carnicer, 2001: 211.

255 "Las Conversaciones Cinematográficas de Salamanca”. En Arriba, 29 de junio de 1955.

${ }^{256}$ Editorial de Objetivo. Núm. 7, julio de 1955.
} 
coincidiendo con la segunda etapa de García Escudero al frente de la Dirección General de Cinematografía. La primera medida fue la elaboración de un código de censura ${ }^{257}$ y la reorientación del sistema de protección a partir de la unificación administrativa, la concesión de los créditos previos a los nuevos productores y el establecimiento del criterio de calidad artística para la concesión de las ayudas a películas ya realizadas. Además se fijó una cuota de distribución para el cine español ${ }^{258}$, la restricción paulatina del doblaje, la creación de una entidad para la distribución del cine nacional en el extranjero y la completa unificación de los entes ministeriales de índole cinematográfica en torno al Ministerio de Información y Turismo. También se procuró la potenciación del IIEC, la creación de una Federación Nacional de cineclubs, la incorporación de la enseñanza del cine al ámbito universitario, la desmonopolización de la realización de Noticiarios y Documentales, NO-DO, así como la inclusión de los documentales y cortometrajes en los beneficios económicos de que gozaban los largometrajes ${ }^{259}$.

Las Conversaciones de Salamanca se sumaban a la exigua línea contestataria que, surgida en los márgenes del poder franquista, cuestionaba el monolitismo político-cultural del régimen. Cabe citar una serie de precedentes entre los que se encuentra la Asamblea Nacional de Universidades y el Congreso Nacional de Estudiantes celebrados ambos en 1953 con el objetivo de concienciar a la élite gestora franquista del estado y urgente dignificación del sector educativo y concretamente universitario. $Y$ aunque de diferente naturaleza, la huelga de tranvías de Barcelona en 1951 convertida en huelga general, "primera gran insurrección ciudadana pacífica de carácter masivo contra el régimen ${ }^{260 "}$.

\footnotetext{
${ }^{257}$ Clamaba Juan Antonio Bardem "que la censura nos muestre su rostro, nos enseñe la salida de su laberinto, nos codifique lo prohibido". En la argumentación del apartado 'Industrialmente raquítico' de Informe sobre la situación actual de nuestra cinematografía. En Objetivo. Núm. 6, junio de 1955.

${ }^{258}$ Que fundamentaría la Orden de 14 de julio de 1955 sobre la distribución de películas españolas estableciendo la cuota de un título español por cada cuatro extranjeros.

259 'Conclusiones aprobadas.' En Objetivo. Núm. 6, junio de 1955.

${ }^{260}$ Gracia, 2001: 208.
} 
El encuentro salmantino, sumado a las revueltas universitarias de 1956 significó un pulso al régimen franquista que rápidamente fue paliado con la dimisión de Joaquín Ruiz-Giménez ${ }^{261}$ de la cartera de Educación, de Manuel Torres López ${ }^{262}$ de la Dirección General de Cinematografía en abril de 1956 y de Laín Entralgo como rector de la Universidad de Madrid. Se clausuró la revista Objetivo ${ }^{263}$ y se procedió al encarcelamiento de Juan Antonio Bardem durante el rodaje de Calle Mayor. También se restringió el margen de permisibilidad que antes había acogido la celebración de un encuentro como el salmantino prohibiéndose el I Congreso Nacional Universitario de Escritores Jóvenes previsto para febrero 1956. Un contexto de persecución generalizada a pesar de la cual quedó patente que iniciativas como las Conversaciones de Salamanca u otras manifestaciones contestatarias habían prendido la llama de la resistencia cultural y política en el ámbito estudiantil ${ }^{264}$ obligando a declarar el estado de excepción en febrero de 1956.

\footnotetext{
${ }^{261}$ De cuyo equipo liberal formaba parte el rector de la Universidad de Salamanca, Antonio Tovar.

${ }^{262}$ El cual en una entrevista a la revista Arriba se pronunciaba respecto a la idea de unificación aparecida durante las Conversaciones de Salamanca. Añadiendo que "no hay mas que una sola forma de hacer esa unificación -la de los organismos oficiales de índole cinematográfica-: que la Dirección General de Cine y Teatro sea una realidad". Reproducido en la editorial de Objetivo, núm. 7, julio de 1955.

${ }^{263}$ Aunque el debate prosiguió en las páginas de Cinema Universitario, perpetuando el legado de Objetivo, y Film Ideal, este último desde la línea católica también presente en Salamanca.

${ }^{264} \mathrm{Al}$ ámbito universitario como propulsor de una actitud crítica para con el régimen franquista se dirigió Martín Patino en su discurso inaugural de las Conversaciones de Salamanca: "cuando las juventudes universitarias no son capaces de adaptarse a los rutinarios moldes y se rebelan con los nuevos afanes, son tachadas siempre de snobs e iconoclastas. Pero tenemos fe absoluta en que ese inadaptarse, esta exigencia y rebeldía latente, bajo la capa tranquila de nuestras Universidades, ha de ser la savia más eficaz en estas empresas culturales”. Reproducido en Objetivo, núm.6, junio de 1955.
} 


\section{El paisaje, entidad cultural}

\subsection{Sobre la genealogía del paisaje}

"The form of landscape is thus first of all the form of a view, of a particular gaze that requires a frame. With that frame nature turns into culture, land into landscape ${ }^{265 "}$.

El paisaje es el espacio natural admirable por su aspecto artístico, define la Real Academia de la Lengua Española. La relación del espacio natural con el concepto de paisaje surge a raíz del ejercicio de posicionamiento del ser humano -como sujeto- frente a la naturaleza -como objeto- ordenándola en su expresión artística. Desde una perspectiva historiográfica, como describe la ilustradora e investigadora francesa Hélène Saule-Sorbé, el entorno natural campo, monte o mar- ya existía sin el ser humano, no así el paisaje que se constituye como "entidad perceptual, y por consiguiente cultural" necesitando de una "presencia en el lugar" o un "estar en el lugar ${ }^{266 ", ~ q u e ~ N a t h a n ~}$ Richardson llama "notions of being in place ${ }^{267 "}$.

La constitución de la entidad paisaje "that with which we see ${ }^{268 "}$ se inicia en el campo artístico. Javier Maderuelo defiende que "no ha empezado a haber contemplación del entorno como paisaje hasta que los artistas no han comenzado a representarlo, lo que conduce a la confirmación de una utilidad añadida a la pintura, la de servir como escuela de la mirada ${ }^{269 " . ~ F u e ~}$ precisamente en la disciplina pictórica donde se gestó el interés por la representación del espacio natural, urgiendo con ello de una definición terminológica. Al carecer de referente latino, la primera constancia en un léxico se encuentra en el ámbito del taller francés del siglo XVI, en concreto en la reedición del Dictionnaire François-latin de Robert Estienne de 1549

\footnotetext{
${ }^{265}$ Lefebvre 2006: XV. "Así, la forma del paisaje es en primer lugar la forma de una mirada, de una mirada particular que requiere de un marco. Con ese marco la naturaleza se convierten en cultura, la tierra en paisaje". Traducción de la autora.

${ }^{266}$ Ortega, 2006: 52.

${ }^{267}$ Richardson, 2012.

${ }^{268}$ En palabras de John Wylie reproducidas en Davies, 2012: 5. "El paisaje como aquello con que vemos". Traducción de la autora.

${ }^{269}$ Maderuelo, 2005: 32.
} 
donde se incluía paysage por ser "mot commun entre les peintres"270". Pero hay rastro del vocablo en la Holanda de finales del siglo XV en que Landschap designaba la "amplitud de país visto en todas las direcciones, desde un centro determinado por la mirada del hombre ${ }^{271 "}$. En Alemania se conoce Landschaft desde que Durero lo emplease en la correspondencia ${ }^{272}$ con Jacob Heller para hablar de las pinturas de Patinir. En lengua inglesa la palabra land-scape se empleó desde 1603, y unida desde 1725, anteriormente se utilizaba landskip. En italiano el término paese se usó a partir del siglo XII y paesaggio desde que Tiziano lo utilizase en una misiva fechada el 11 de octubre de 1552. Y, finalmente, en lengua española la primera constancia escrita se encuentra en el diccionario de Corominas de 1708.

La tardía aparición del término 'paisaje' en el contexto occidental, y en concreto español, se debe al hecho que no todas las culturas son paisajísticas, advierte Agustín Berque ${ }^{273}$. Como ejemplo, en la Antigua Grecia solo precisaron de los términos 'topografía' -lugar real- y 'topotesia' -lugar ficticio- para afrontar la descripción del espacio natural. Martin Lefebvre rescata los términos griegos originales y argumenta que parergon se refiere al estadio del paisaje "as spatial accessory to a painted scene (the scene -not the scenery- being the principal subject matter or argument of a painting) or as a simple element accompanying a larger ensemble)". Y ergon cuando se trata del paisaje "as the primary and independent subject matter of a work ${ }^{274 ",}$ estadio que deriva en una multiplicidad de formas y técnicas artísticas. En definitiva, el ejemplo griego demuestra que toda construcción terminológica es una convención cultural que varía de una sociedad a otra en cuestión de sus necesidades. A lo que el historiador del cine Alan Salvadó añade:

"La teoria i la historia del paisatge a Occident són relativament joves. La major part de les reflexions $i$ aproximacions al paisatge són deutores del que podriem anomenar un discurs paisatgístic que s'inicia

\footnotetext{
${ }^{270}$ Y que se mantuvo en el Trésor de la langue Françoise de Jean Nicot de 1606.

${ }^{271}$ Maderuelo, 2005: 32.

${ }^{272}$ Fechada entre 1508 y 1521.

273 "Paysage, milieu, histoire". En Berque: 1994.

${ }^{274}$ Lefebvre, 2006: 23.
} 
a finals del segle XVIII amb l'idealisme alemany i les investigacions geogràfiques d'Alexander von Humboldt. A partir d'aquí, teòrics com George Simmel $i$ Joaquim Ritter assenten alguna de les bases per a pensar el paisatge a les portes del segle XX; bases que reprenen o reactualitzen altres teòrics més contemporanis com Simon Schama, Kenneth Clark Alain Roger, Augustin Berque o el propi Michael Jakob $^{275 "}$.

En cuanto a la evolución del paisaje occidental, prosigue Salvadó:

"S'ha articulat, principalment, al voltant d'una (gran) dialèctica: la Ilunyania i la proximitat [.... L. L'elecció d'una distància adequada des de la qual contemplar la natura ha pautat les diferents metamorfosis que ha experimentat el paisatge des de la seva gènesi al segle XV fins els nostres dies ${ }^{276 " .}$.

El paisaje en Occidente nace en y de la lejanía, a diferencia del paisaje oriental, entidad que debido a su relación con los sujetos que lo habitan se convierte en objeto autónomo. En esta línea coincide Jean Mottet que "to be a landscape, the space must be organised into a coherent unit" a lo que Ann Davies añade que "this unit is created through distance 277 ". Es precisamente la acción de retroceder para tomar distancia respecto al paisaje la que marcó el tránsito de la Edad Media al Renacimiento, cuando el ser humano "s'allibera de la Totalitat de la Naturalesa i pren autonomia a l'interior de l'engranatge còsmic del que fins llavors havia format part ${ }^{278 " . ~ U n ~ g e s t o ~ d e l ~}$ que emergió una nueva concepción del mundo. En palabras del autor "en

\footnotetext{
${ }^{275}$ Salvadó, 2012: 27. "La teoría y la historia del paisaje en Occidente son relativamente jóvenes. La mayor parte de las reflexiones y aproximaciones al paisaje son deudoras del que podríamos llamar un discurso paisajístico que se inicia a finales del siglo XVIII con el idealismo alemán y las investigaciones geográficas de Alexander von Humboldt. A partir de aquí, teóricos como George Simmel y Joaquim Ritter asientan alguna de las bases para pensar el paisaje a las puertas del siglo XX; bases que retoman o reactualizan otros teóricos más contemporáneos como Simon Schama, Kenneth Clark, Alain Roger, Augustin Berque o el propio Michael Jakob". Traducción de la autora.

${ }^{276}$ Ídem: 29. "Se ha articulado, principalmente, en torno a una (gran) dialéctica: la lejanía y la proximidad [...]. La elección de una distancia adecuada desde la que contemplar la naturaleza ha pautado las diferentes metamorfosis que ha experimentado el paisaje desde su génesis en el siglo XV hasta nuestros días". Traducción de la autora.

${ }^{277}$ Mottet. "Toward a Genealogy of the American Landscape: Notes on Landscape in D. W. Griffith (1908-1912)”. En Lefebvre, 2006: 65.

278 ídem: 33. "[Cuando el ser humano] se libera de la Totalidad de la Naturaleza y toma autonomía en el interior del engranaje cósmico del que hasta entonces había formado parte". Traducción de la autora.
} 
aquest gest de recul del que parla Alain Roger ${ }^{279}$ trobem la doble operació que dóna llum al paisatgisme occidental: el (re) descobriment de la natura $i$ l'agrupament (a través de la mirada) dels elements que la componen i li donen una forma determinada ${ }^{280 " .}$

En conclusión, la distancia es el elemento constitutivo del paisaje occidental respecto al oriental. Mientras que este último nacía de la asociación con la práctica caligráfica y literaria, el primero lo hacía de la práctica pictórica, razón por la que llevaba implícita en su naturaleza la cuestión estética. Cabe anotar que esta cuestión no forma parte de la definición del concepto 'paisaje' hasta la edición de 1690 del Dictionnaire Universel de Antoine Furetière que define el término como "l'aspect d'un pays, le territoire qui s'étend jusqu'où la vue peut porter. Les bois, les collines et les rivières Font les beaux paysages ${ }^{281 " . ~ U n a ~ n u e v a ~ a c e p c i o ́ n ~ q u e ~}$ establecía la definición del término en base a la experiencia individual del sujeto que, en disposición de contemplar una realidad natural, experimentaba un sentimiento estético derivado de las cualidades armónicas de los componentes del lugar.

\footnotetext{
${ }^{279}$ " Avec le recul, nous pouvons dire que l'invention du paysage occidental supposait la réunion de deux conditions. D'abord, la laïcisation des éléments naturels, arbres, rochers, rivières, etc. Tant qu'ils restaient soumis à la scène religieuse, ils n'étaient que des signes, distribués, ordonnés dans un espace sacré, qui, seul, leur conférait une unité [...] II faut donc que ces signes se détachent de la scène, reculent, s'éloignent, et ce sera le rôle, évidemment décisif, de la perspective. [...] la seconde condition: il faut désormais que les éléments naturels s'organisent eux-mêmes en un groupe autonome, au risque de nuire à l'homogénéité e l'ensemble " Roger, A. Court traité du paysage. Paris, Éditions Gallimard, 1997 : 70. Reproducido en Salvadó, $2012: 34$.

${ }^{280}$ Ibídem. "En este gesto de recul del que habla Alain Roger encontramos la doble operación que da luz al paisajismo occidental: el (re) descubrimiento de la naturaleza y el agrupamiento (a través de la mirada) de los elementos que la componen y le dan una forma determinada". Traducción de la autora.

281 "Aspecto de un país, el territorio que se extiende hasta perderse de vista. Los bosques, las colinas, los ríos hacen los paisajes hermosos". Traducción de la autora. El glosario cuyo nombre completo es Dictionnaire Universel, contenant généralement tous les mots François, tant vieux que modernes, et les termes des sciences et des arts fue publicado póstumamente en Rotterdam.
} 


\subsubsection{La representación artística del entorno rural}

Debido a la función de las diferentes disciplinas artísticas en el desarrollo del paisajismo, surge la hipótesis por la cual en suma la pintura, la literatura, la fotografía y el cine, más allá de ser representaciones figurativas del entorno rural, constituyen en sí mismo lenguajes capaces de "expresar lo que era el paisaje, de describir sus formas constitutivas y las conexiones existentes entre ellas, de dar cuenta de su dimensión visual, fisonómica, y [...] expresar también, al tiempo, sus atributos cualitativos, sus valores y sus

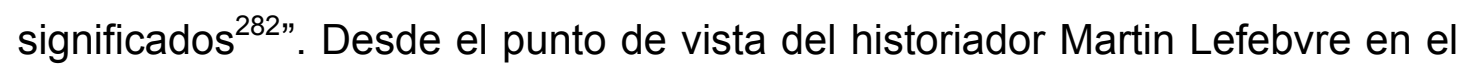
marco de sus estudios sobre el uso espacial en el cine, "this is not to say that landscape art is a simple mirror reflection of that artifice, for art is a place where the 'artifice of landscape' develops and transforms itself, a place where human beings not only recognize their investment in space but also redefine it $^{283 "}$.

Desde el siglo $\mathrm{XV}$, la producción artística ha evolucionado conforme a las demandas propias de cada contexto y tiempo ofreciendo a cada momento unos modos de ver y pensar el paisaje que, desde una perspectiva historiográfica, constituyen corrientes ideológicas y estilísticas. Un hecho presente en el paisajismo como género, fenómeno en que convergieron tanto experiencias científicas, corrientes de pensamiento y expresiones artísticas.

La pintura en un primer momento $y$, posteriormente, la fotografía y el cine han dejado constancia visual de la unidad estética y compositiva del espacio rural. La disciplina pictórica, ya desde el siglo XV, observó el entorno natural desarrollando la variante del paisajismo dentro de los géneros pictóricos. De este modo constituyó una forma de pensamiento del ser humano como individuo frente a la naturaleza y por ende de posicionamiento en la realidad

\footnotetext{
${ }^{282}$ Ortega, 2006: 9.

${ }^{283}$ Lefebvre, 2006: XIV. "Esto no quiere decir que el arte del paisaje sea un simple reflejo de este artificio, para el arte es un lugar donde el "artificio del paisaje" se desarrolla y transforma, un lugar donde los seres humanos no solo reconocen su incidencia en él si no que lo redefinen". Traducción de la autora.
} 
que lo circundaba, erigiéndose en vehículo para la conformación de la "escuela de la mirada" de que habla Javier Maderuelo ${ }^{284}$. En conclusión, la pintura, como el resto de artes visuales, en el ejercicio observacional de dar cuenta de lo real en su dimensión visual, revela un posicionamiento concreto del autor en que confluyen determinantes geográficos, sociales e ideológicos en la traducción estética de la visión del entorno rural, en este caso.

Generalmente, la construcción de la mirada sobre el entorno rural es un fenómeno desarrollado por individuos ajenos a él. Este hecho comporta una distancia física inicial salvable con un desplazamiento, el viaje ${ }^{285}$. Sin embargo, tal circunstancia adquiere una relevancia significativa cuando se profundiza en las razones que sustentan las representaciones que un viajero -desde su condición de extranjero- realiza de un entorno. En primer lugar, todos aquellos autores que en el campo de su disciplina han abordado la cuestión rural comparten el interés por descubrir este espacio, lo cual implica, en menor o mayor grado, cierta sensibilidad que facilitará la empatía con el nuevo entorno. No obstante, las obras resultantes carecen del componente propio de la experiencia vivida, entiéndase como aprehendida, del nativo del lugar. En conclusión las experiencias de los viajeros responderá a unas miradas aprendidas, nostálgicas, románticas o peyorativas. Sin embargo, son las miradas de autores como Jean-François Millet y Rosa Bonheur en pintura, Florián Rey, Manuel Mur Oti o Juan Antonio Bardem en cine las que han constituido el imaginario paisajístico, pues los habitantes rurales en muy pocas ocasiones han tenido la oportunidad de contarse a sí mismos. Al respecto Emile Zola con sorna sostenía que "los campesinos no ven el campo. Lo miran y lo ven más o menos como una vaca, como posibilidad rentable $^{286 "}$. De lo que se concluye que la historia del entorno rural en general, y del campo español en particular, es un relato construido por terceros.

\footnotetext{
284 Maderuelo, 2005: 32.

${ }^{285}$ En la línea de Salvadó (2012: 9) el viaje entendido como "una revelación o si se quiere, un bouleversement, de los conocimientos y experiencias previas del viajero. En la época de gran masificación del turismo, esta reacción del viajero trazada por Magris desaparece en detrimento de la búsqueda de aquello conocido". Traducción de la autora.

${ }^{286}$ Reproducido en García de León, 1992: 214.
} 


\subsubsection{El viaje en la construcción moderna del paisaje}

Reflexiona Nicolás Ortega sobre como las corrientes de pensamiento modernas pretendían "ver y valorar el paisaje de forma más 'naturalista', con criterios menos 'idealistas' y más 'positivistas' que los defendidos por los románticos". Un ejemplo del dinamismo con que la cuestión del paisaje ha ido desarrollándose hasta la actualidad se encuentra en la comprensión del paisaje como "resultado histórico, una expresión cultural que ha ido renovándose con el paso del tiempo [e] incorporando los horizontes culturales de cada momento ${ }^{287 "}$.

"Los viajeros extranjeros fueron los primeros que dieron a conocer a través de sus narraciones (en forma de pintura, dibujo o grabado), el modo moderno de ver el paisaje, asociado al horizonte romántico, que había arraigado en Europa desde la segunda mitad del siglo XVIII" y que se asentaba en "perspectivas naturalistas y geográficas ${ }^{288 " . ~ E s t o s ~ p i o n e r o s ~ t u v i e r o n ~ q u e ~}$ enfrentarse a la puesta al día del léxico estético que mejor diese cuenta de su experiencia vivida. De los escritos de los viajeros que recorrieron las provincias de Aragón entre mediados del siglo XVII y mediados del XIX la investigadora Esther Ortas (1999) ha detectado la incorporación de los términos bello, sublime, pintoresco, romántico, agradable, imponente, terrible, horrible y salvaje a la descripción de sus vivencias. A su vez también se incorporaron otros muchos vocablos de origen naturalista y científico para describir empíricamente los entornos naturales. Una suma de formulaciones retóricas de la literatura de viajes que influenciaría la literatura moderna. Como muestra la coincidencia en tiempo de la publicación de los textos de corte naturalista y geográfico de Ferdinand de Saussure (1857-1913), Louis Ramond de Carbonnàires (1755-1827) o Alexander von Humboldt (17691859) junto a los literarios de Jean-Jacques Rousseau (1712-1778), JacquesHenri Bernardin de Saint-Pierre (1737-1814) o François René de

\footnotetext{
${ }^{287}$ Ortega, 2006: 39.

288 Ídem: 37.
} 
Chateaubriand (1768-1848) ${ }^{289}$. La obra de Rousseau es paradigmática de esta conjunción de estilos literarios. Como buen polímata cultivó las disciplinas de la música, la escritura, la botánica y la pedagogía, entre otras muchas. El encuentro con el botánico Jean-Antoine d'Ivernnois despertó en él la pasión por el medio natural, afición que se tornó en dedicación a su estudio y divulgación en trabajos literarios, descubriendo el paisaje alpino a sus lectores. Posteriormente la ingente producción literaria de Rousseau de análisis y entendimiento de las relaciones del ser humano con su entorno y tiempo impregnó la obra de Horace-Benedicte de Sausurre (1740-1799) en la descripción del lago de Ginebra en su Viajes a los Alpes (1779-96). También influyó en la construcción moderna del concepto 'paisaje' de von Humboldt, cuyos preceptos de partida conjugaban la descripción con la expresión sentimental del autor, en la línea de los postulados del romanticismo literario. Un ejemplo lo constituye Cosmos (1845) donde el naturalista reconocía que "desde la segunda mitad del siglo XVIII, la prosa descriptiva, especialmente, ha adquirido una fuerza y exactitud enteramente nuevas", en referencia al trabajo de Rousseau, Saint-Pierre, Chateaubriand, Schiller, Goethe, Byron y Forster $^{290}$.

\subsubsection{La dualidad campo-ciudad}

"El paisaje es un constructo, una elaboración mental que los hombres realizamos a través de los fenómenos de la cultura ${ }^{291 " .}$.

La gran mayoría de las discusiones en torno a la cuestión rural toman como eje aproximativo la dualidad campo-ciudad. Dualidad histórica también en el empleo de los calificativos de "rusticidad" y "urbanidad" con los juicios que ello conlleva, asentándose, además, en las expresiones artísticoculturales que se han ocupado del fenómeno. El discurso hegemónico ha perpetuado una relación imaginaria de opuestos entre ambos núcleos geográficos y sociales en que la definición de la especificidad de cada

\footnotetext{
289 Ídem: 26.

${ }^{290}$ Reproducido en Ortega, 2006: 11.

${ }^{291}$ Maderuelo, 2005: 17.
} 
entorno viene dada, en gran medida, a partir de su reafirmación por contraste con 'el otro'. No obstante las académicas Catherine Fowler y Gillian Helfield (2006) proponen romper con este mito para tratar los puntos de tensión que han unido de manera inextricable ambos entornos. $Y$ es que ni la ciudad es la cuna del progreso que a todos beneficia, ni el campo es el último reducto de atavismo y miseria.

Sin embargo esta práctica se constata en las definiciones que ofrecen los diccionarios de lengua. La Real Academia Española de la Lengua, RAE, en su única acepción define 'rural' como "lo perteneciente o relativo a la vida del campo y sus labores". No obstante en enero de 2012 fue suprimida una segunda definición que explicaba lo 'rural' como "aquello inculto, tosco, apegado a las cosas del lugar y por tanto relacionado con la deficiencia". Explica el 'campo' como "el "terreno extenso fuera de poblado. La tierra laborable. Sembrados, árboles y demás cultivos". Aunque la RAE no vincula el término rural a los espacios del bosque o el monte, en el afán por abordar y redefinir el concepto de 'entorno rural' de este trabajo se incluyen no solo los campos de cultivo, sino también los bosques, las montañas, el mar, los ríos y los lagos, lugares en los que en mayor o menor medida el ser humano interviene. De este modo, la definición del entorno rural implica tener en cuenta el paisaje como entorno natural inalterable pero también como entorno natural condicionado por la presencia y el trabajo de la comunidad humana que lo ocupa.

La 'ciudad', define la RAE, es el "conjunto de edificios y calles, regidos por un ayuntamiento, cuya población densa y numerosa se dedica por lo común a actividades no agrícolas". Y 'urbano' aquello “cortés, atento y de buen modo". En definitiva estas definiciones de 'campo-rural' y 'ciudad-urbano' perpetuan la polarización de ambos entornos en que tradicionalmente la ciudad se ha erigido como valor dominante desde el instante en que ha proyectado un estado de opinión sobre el campo. Un ejemplo temprano lo constituye la entrada sobre Las Hurdes en el Diccionario geográfico-estadístico-histórico de España y sus posesiones de Ultramar de Pascual Madoz, 1846. En él se tachaba a los habitantes del lugar de "raza degenerada e indolente", "borrón 
de la civilización española", "salvajes e inmorales"292. Ilustrativa de este juicio sobre la región española es la anécdota que recoge Sergio del Molino sobre el procesamiento por sedicioso del doctor José María Albiñana condenado a destierro a Las Hurdes. En otra palabras, esta sentencia revela la no consideración de la comarca extremeña como parte de la España civilizada $^{293}$.

La asociación 'campo-ciudad' fue un fenómeno considerablemente arraigado aún en la década de los ochenta como demuestra la disertación de Jesús González Requena en torno al concepto de ruralidad y su tratamiento en el cine español. Según este autor, el cine español ahonda en su sesgo peyorativo en beneficio del espacio urbano. Sus razonamientos se sustentan en la historicidad de dichos posicionamientos valorativos. En el texto Apuntes para una historia de lo rural en el cine español ${ }^{294}$ González Requena construye un cuadro de opuestos en que enumera los ítems definitorios del entorno rural y urbano. Por aquello de los buenos valores y la buena conciencia, la ciudad se caracteriza por la mediación social, la flexibilidad, el dinamismo social, el liberalismo y un carácter sofisticado; es contenedora de progreso y transformación social. Mientras que el campo se define por la ausencia de mediación, la inflexibilidad, el estatismo social, el conservadurismo, el atavismo, el inmovilismo y un marcado carácter primario.

La confrontación de ambos núcleos geográficos -uno portador de los valores positivos y el otro de los negativos- influyó en el fenómeno migratorio en que, a nivel internacional, los campesinos huían a la ciudad esperanzados por encontrar allí la salvación. Un fenómeno que el sociólogo francés $P$. Bourdieu en Reproduction interdite llamó '“conversión colectiva' de la visión del mundo que otorga al campo social arrastrado un proceso objetivo de unificación, un poder simbólico fundado en el reconocimiento unánime acorde a los valores dominantes ${ }^{295}$ ". La lectura en los términos propuestos por Bourdieu del éxodo rural español del siglo XX resulta paradigmática si se

\footnotetext{
${ }^{292}$ Reproducido en del Molino, 2016: 111.

293 Ídem: 112.

${ }^{294}$ Aguilar, 1988: 13-26, 16.

295 Bordieu: 1989, 15-35.
} 
tienen en cuenta los postulados del régimen franquista, al menos en sus postulados iniciales, sobre el entorno rural donde "the seed of the race remains purer and people live their problems and they are not polluted with the city's depravity ${ }^{296 " . ~ P e r o ~ l a ~ r e a l i d a d ~ p r o d u c i ́ a ~ u n ~ c h o q u e ~ s o c i a l ~ y ~ c u l t u r a l ~}$ puesto que los inmigrantes del campo encontraban en las ciudades la perversión de los valores y de los modos de vida propios de la comunidad rural de donde provenían. Esto le sucede a Acacia, la protagonista de la Aldea Maldita de Florián Rey, 1930 y 1942 o a la familia Pérez de Surcos de José Antonio Nieves Conde, 1951 que se topan con

Por cuanto se ha argumentado hasta el momento, la confrontación del entorno rural y urbano arraigó en el imaginario colectivo haciendo de ambos dos entidades irreconciliables. No obstante, y atendiendo a la universalización del fenómeno, el sociólogo polaco Boguslaw Galeski, precursor de los estudios campesinos, reprendió dicha confrontación apostando por la definición de ambos entornos de manera equitativa, pues hasta el momento se habían enfatizado "elementos diferenciales que resultan ser propios de la forma de vida de cada lugar". Es más, Galeski tampoco contemplaba una dicotomía sino la existencia de "tipos ideales [con] una

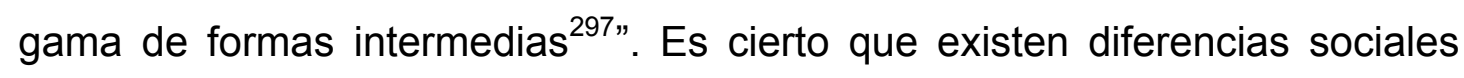
entre los núcleos urbanos y rurales como consecuencia del retraso con que llegan a las aldeas procesos que ocurren en la sociedad global ya que históricamente, y principalmente en el siglo XX, "the city was the privileged site for the cultural manifestation of the influence of capital ${ }^{298 " . ~ E s t o ~ s e ~ d e b e, ~}$ en gran medida, al desarrollo desigual que impone el capitalismo entre la ciudad y el campo en el nivel productivo, entre la industria y la agricultura, y que "ejecutan una poderosa influencia sobre el cambio social y cultural en la aldea en general, incluida la estructura del estrato campesino ${ }^{299 " . ~ P o r ~ s u ~}$ parte la comunidad campesina desarrolla unas condiciones de vida rural

\footnotetext{
296 "La esencia de la raza permanece pura y las gentes viven sus vidas sin problemas sin ser contaminados por la depravación de la ciudad". Traducción de la autora. Sevilla-Guzmán, E. "The Peasantry and the Franco Regime". En Preston, 1976: 109.

297 Galeski, 1977: 135.

${ }^{298}$ Richardson, 2012: 53. "La ciudad era el lugar privilegiado para la manifestación cultural de las influencias más destacadas". Traducción de la autora.

${ }^{299}$ Galeski 1977: 181.
} 
derivadas de las dificultades físicas al intervenir en entornos naturales y sus rasgos propios que dan lugar a un "sistema social de tipos diferentes del de los asentamientos urbanos ${ }^{300 " . ~}$

Por el contrario, desde otras perspectivas también serían legítimas aquellas lecturas de lo urbano como espacio de alienación de sus habitantes desprovisto de todo valor moral o espiritual. En cuanto a su mise-en-scène esta "can express a strong sense of claustrophobia: compressed and clogged with the detritus of city life, may delimit opportunities of growth". Mientras que la puesta en escena del entorno rural se podría construir "with its open, uncluttered vistas of big sky and expansive terrain, may also suggest a barren and lonely wasteland ${ }^{301}$ ". En definitiva se concluye que el entorno urbano y el rural participan, acorde a sus particularidades constitutivas, de la construcción de la identidad de sus comunidades sociales, el uno en términos de desarrollo social, tecnológico y económico y el otro como contenedor de las tradiciones y los modos de vida en estado más puro.

Lejos de contribuir a la perpetuación de una categorización positiva o negativa de cualquiera de los espacios, tal y como defendieron Galeski, Fowler y Helfield, este trabajo contempla el análisis del entorno rural en toda su amplitud atendiendo a sus mecanismos de ordenación, sus ciclos constitutivos y los modos de vida allí desarrollados.

\subsubsection{El entorno rural, espacio de identidad colectiva}

"La montaña no solamente es un accidente del relieve, es sobre todo un medio de vida, una creación permanente, en la que se enfrentan las poderosas fuerzas de la naturaleza y la capacidad creadora de los

\footnotetext{
300 Ídem: 113.

${ }^{301}$ Fowler; Helfield, 2006: 3. "[La mise-en-scène del espacio urbano] puede expresar un sentido fuerte de claustrofobia, comprimida y obstruida por los detritus de la vida urbana pudiendo delimitar las oportunidades de crecimiento. Mientras que la mise-en-scène del entorno rural se construye con sus vistas abiertas y despejadas de grandes cielos y extensos terrenos pudiendo sugerir también un erial árido y solitario". Traducción de la autora.
} 
hombres en busca de su propia supervivencia -cultivos en bancales, caminos inverosímiles, puentes inimaginables ${ }^{302 "}$.

Esta afirmación de Valentín Cabero Diéguez fundamenta una de las hipótesis de partida de este análisis por cuanto el entorno rural se entiende como la suma del espacio natural y la comunidad social que lo ocupa "whose lives and daily activities give this space its meaning and value ${ }^{303 " . ~ U n a ~}$ relación que contribuye a la estereotipación de sus habitantes, por lo que la inicial delimitación del marco rural como mero espacio geográfico queda superada en aras de una dimensión social. De lo que se concluye que el rural es un espacio de definición y reconocimiento para la formación social.

El medio rural es contenedor de una comunidad social diferenciada "en el que se conserva, más aún que antiguos usos y costumbres, la tradición del trabajo fatigoso, de la vida sobria y ruda y de la libertad en la pobreza ${ }^{304 " . ~ " I t ' s ~}$ frequently cast as the site of cultural tradition and heritage" mientras que el medio urbano, metonimia de la ciudad, es "the working country ${ }^{305 " . ~ A m b a s ~}$ realidades espaciales forman parte del todo geográfico y social contribuyendo a la definición de la identidad nacional. La realidad urbana en términos de desarrollo tecnológico y económico y la rural en aras de "its depiction of traditional folkways and mores and its evocation of continuity despite the march of time and change ${ }^{306 " . ~ U n ~ a r g u m e n t o ~ q u e ~ e x p l i c a r i ́ a ~ l a ~ d i s p l i c e n c i a ~}$ histórica a que ha sido sometido el entorno rural. Aunque por otro lado, éste también es su principal valor al constituirse en el mayor depositario de la tradición y esencia identitaria de una nación en mutación, como fue el caso de la modernización de España a mediados del siglo XX. En cierto modo, el impacto modernizador experimentado en la urbe ocasionó que las manifestaciones artístico-culturales sobre lo rural fuesen interpretadas como representaciones legítimas del concepto nación.

\footnotetext{
302 Martínez de Pisón, 2000: 104.

${ }^{303}$ Fowler; Helfield, 2006: 6. "Cuyas vidas y actividades diarias dan a este espacio su significado y valor". Traducción de la autora.

${ }^{304}$ Herzog, 1967: 250.

${ }^{305}$ Fowler; Helfield, 2006: 2. "Es frecuentemente erigido como el lugar de la herencia y la tradición cultural". Traducción de la autora.

${ }^{306}$ Ibídem. "Su descripción de las tradiciones populares y costumbres y su evocación de continuidad a pesar del paso del tiempo y del cambio". Traducción de la autora.
} 
La concepción del entorno rural se ha cimentado sobre los testimonios de viajeros que provistos de un cuaderno de notas o una cámara fotográfica osaron traspasar las fronteras de los caminos principales durante el siglo XIX y la primera mitad del siglo XX, principalmente. A su vuelta Ortiz Echagüe, Gutiérrez Solana, Miguel de Unamuno, Azorín o Luis Buñuel mostraban al desconocedor público urbano su experiencia en forma de pintura, fotografía, novela o película. Cuando llegaban al lugar, los artistas e intelectualesviajeros adoptaban, por lo general, actitudes de respeto y admiración, con cierta patina condescendiente, a la vez que de temor ante un enclave en aras de extinción con la inminente llegada del progreso al Estado español.

A lo largo del siglo XIX y principios del XX los fotógrafos José Ortiz Echagüe, Jean Laurent y Charles Clifford o Hinschfield se apresuraron a visitar los pueblos españoles para inmortalizar con sus lentes fotográficas los modos de vida, los rituales festivos y el aspecto físico de unos habitantes amenazados con el trajín modernizador que preveía experimentar el país. También William Eugene Smith se adentró en la península en busca de los efectos negativos de la marginación del campo español. Su reportaje Spanish Ville: it lives in ancient poverty and faith se publicó en la revista Life ${ }^{307}$. Los desplazamientos de estos hombres respondían a inquietudes personales o encargos periodísticos. A esta práctica de viajar a las zonas rurales más apartadas de la geografía española cabe sumar dos proyectos que contribuyeron a tender firmes lazos entre las comunidades de los núcleos urbanos con el interior. El primero fue la Institución Libre de Enseñanza surgió para transformar los modelos pedagógicos a través del contacto con la realidad. Inspirado en las corrientes del romanticismo en pleno auge en el resto de Europa, Francisco Giner de los Ríos, su artífice, pretendía importar el concepto de nacionalismo mediante su célebre tesis de "amar el país a través de la suela de sus zapatos ${ }^{308}$. $\mathrm{Y}$ el segundo tuvo lugar en Catalunya donde fundó en 1876 El Centre Excursionista de Catalunya-Club Alpí Català,

\footnotetext{
${ }^{307}$ En el número 15 del volumen 30, en abril de 1951, 120-129.

${ }^{308}$ Del Molino, 2016: 135
} 
una entidad cultural y deportiva -aun activa en la actualidad- que tenía como objetivo conocer y promover el estudio de la geografía catalana.

A pesar de todo, la cobertura de los medios de comunicación -del pasado y de la actualidad- resulta paradigmática en cuanto a la forma y modo de conocimiento de los habitantes urbanos sobre los núcleos rurales. En palabras de Sergio del Molino: "cuando las aldeas de la España vacía salen en los periódicos nacionales siempre es en la sección de sucesos. La prensa noticia crímenes que acaecen en el campo español, con menor frecuencia que en el urbano, pero que alcanzan mayor repercusión en el imaginario social $^{309 "}$. Un fenómeno que participa de la perpetuación de la mirada peyorativa sobre el entorno rural, por cuanto los periódicos acostumbran a recrearse en la animalidad de los acontecimientos.

'El crimen de Cuenca' fue atroz. Un episodio de injusticia gubernamental sufrida por Gregorio Valero y León Sánchez, habitantes de Osa de la Vega, cuando en agosto de 1910 fueron culpados de la desaparición de El Cepo y torturados por la Guardia Civil hasta confesar un crimen que no habían cometido como demostró el regreso del desaparecido quince años después. En enero de 1933 tuvo lugar 'El caso de Casas Viejas' que conmocionó a la nación entera y marcaría un punto de inflexión en el seno del gobierno de la II República de Manuel Azaña. La contundencia con que la Guardia Civil y la Guardia de Asalto sofocaron la sublevación de un grupo de campesinos, sindicalistas de la CNT en el marco de la Revuelta Anarquista en defensa de un comunismo libertario, se saldó con veinticinco muertos. Ambos incidentes atrajeron la atención del escritor oscense Ramón J. Sender (1901-1982) que, junto al enviado del periódico La tierra, Eduardo Guzmán, constató en primera persona la tragedia ocurrida en el municipio gaditano. Sender recogió el testimonio de los supervivientes en una serie de crónicas que publicó semanalmente en el periódico La libertad compiladas en el libro Viaje a la aldea del crimen. Documental de Casas Viejas, 1934 y El lugar de un hombre, 1939, en que narraba los hechos de 'El crimen de Cuenca'. La obra

309 Ídem: 95. 
de Ramón J. Sender daba nombre y voz a las víctimas rurales de la brutalidad de la Guardia Civil, y por extensión del Estado. Una perspectiva del tratamiento de los entornos rurales por autores ajenos a ellos inusual.

En conclusión, teniendo en cuenta la tradición representativa del paisaje así como la multiplicidad de usos y significados derivados de la experiencia del espacio, el "campo y ciudad pueden ser contemplados y juzgados de forma radicalmente opuesta, según el origen social y la experiencia acerca de ellos de quienes emitan el juicio ${ }^{310 " . ~ " P u e s ~ e n ~ c u a n t o ~ q u e ~ l a ~ v i s t a ~ e s ~ h i s t o ́ r i c a, ~}$ los ojos son sociales, no hay una única objetividad, es el "ojo deformado" ${ }^{311 "}$ del artista el que nos ofrece una verdad" sostiene la fotógrafa Cristina García Rodero. En todo caso, la esencia del paisaje como constructo cultural promueve que "the aim of landscape studies has been to read the landscape for a fuller understanding of the cultural system it reflects [puesto que] Spanish landscapes, spaces and places are not 'a reflection of deeper cultural forces' but a 'consequence of the various practices surrounding and investing in the resources it [the landscape] provides ${ }^{312 " .}$

\subsection{El mito de España}

"A place is more tan that! It is a space that is culturally constructed and invested with particular meaning in more tan a diagrammatic or collocational sense ${ }^{313 "}$.

Las comunidades rurales constituyen pequeños núcleos de población en los rincones más apartados de la geografía de cualquier país. Su distanciamiento, temporal y espacial, conlleva un alto grado de desconocimiento por parte de las gentes ajenas a estos lugares que tienden

\footnotetext{
310 García de León, 1992: 48.

311 Ídem: 253

312 Mitch Rose Gathering 'Dreams of Presence': A Project of the Cultural Landscape. Reproducido en Davies, 2012: 3-4. "El objetivo de los estudios sobre el paisaje ha sido llegar a un entendimiento pleno del sistema cultural que el paisaje refleja [puesto que] el paisaje español, el espacio y los lugares no son el reflejo de corrientes culturales si no la consecuencia del cúmulo de prácticas que envuelven e intervienen en la multiplicidad de formas con que el paisaje se manifiesta". Traducción de la autora.

${ }^{313}$ Fernández. "Afterword: Displacements: The Experience of Vectored Spaces in Peninsular Places”. Reproducido en Davies, 2012: 14.
} 
a desarrollar actitudes de rechazo a la vez que de fascinación hacia 'lo Otro'. A menudo esta actitud se sustenta en las leyendas negras acerca de unas regiones peligrosas y salvajes habitadas por gentes violentas, vulgares e incultas.

Durante los siglos XVIII y XIX Europa vivió una expansión del turismo debido a la instauración de la práctica del viaje por placer. Las élites europeas, ávidas por ampliar sus horizontes más allá de sus lugares de origen, se lanzaron en busca de lugares exóticos que descubrir ${ }^{314}$ un hecho que consolidó la práctica del viaje que dejaba de ser el traslado de un lugar a otro para constituir "la experiencia donde alguien o algo que parecía estar cerca y ser bien conocido se revela extranjero e indescifrable, o bien un individuo, un paisaje, una cultura que considerábamos diferentes y ajenos se muestran afines y emparentados con nosotros ${ }^{315}$ ”. Al inicio del siglo XIX España había quedado fuera de los itinerarios del primer turismo europeo hasta que la encrucijada de las Guerras de Independencia, 1808-1814, dirigió el foco de atención hacia la Península Ibérica.

\subsubsection{La llamada exótica del Quijote. La mirada romántica del paisaje español}

En 1780 la Real Academia Española publicó una edición erudita de la novela de Miguel de Cervantes, El ingenioso hidalgo Don Quijote de la Mancha (1605-1615). Esta edición constituye uno de los casos más representativos de la historia universal en que el imaginario estético ha traspasado las fronteras del imaginario colectivo demostrando cómo "the power to narrate is the power to built nations", citando a Edward Said ${ }^{316}$. De este modo, los enclaves rurales en que discurrieron las andanzas del hidalgo manchego y las gentes con las que se encontró se tomaron como sinécdoque

\footnotetext{
${ }^{314}$ En palabras del escritor de guías de viaje Richard Ford (1845: ix). "To see the cities, and know the mind of men has been, since the days of the Odyssey, the object of travel". ${ }^{315}$ Magris, 2008.

${ }^{316}$ Reproducidas en Richardson, 2012: 11. "El poder de narrar es el poder de construir naciones". Traducción de la autora.
} 
de la identidad nacional, entonces -y aún hoy día- exportada fuera de España con el éxito internacional que cosechó la novela. La particular visión de Cervantes de la meseta castellana ofrecía cierta dosis de exotismo de un terreno neutral entre el sombrero y el turbante ${ }^{317}$, esto es, entre la exótica África y la refinada Europa, que tanto gustaba a la élite europea, participando así de la llamada al turismo extranjero.

El influjo exótico de la España de Cervantes calaba en Europa motivando a sus literatos y demás pensadores a tomar la pluma para describir sus ensoñaciones románticas. Entre las obras más representativas se encuentran Hernani de Víctor Hugo, 1830, Cuentos de la Alhambra de Washington Irving, 1832, Carmen de Prosper Mérimée, 1847 o El trovador de Antonio García Gutiérrez adaptada por Giuseppe Verdi en 1853. Si bien, cabe señalar una circunstancia al respecto de la extrañeza de gran parte de los autores que describían España, y es que las más de las veces no llegaron siquiera a viajar al lugar objeto de sus disertaciones. No hay constancia que el escritor ruso Alexandr Pushkin viajara a España en el proceso de documentación para su poema Los gitanos, 1827, ni tampoco lo hiciese el polaco Jan Potocki para redactar Manuscrito encontrado en Zaragoza, 1804-1805. Una producción que, concebida desde la naturaleza de la distancia, nutría el imaginario colectivo de los arquetipos del bandido, las flamencas, don Juanes y gitanos, epítome todos ellos de un imaginario español idealizado.

El impacto del fenómeno cervantino en el contexto europeo experimentó una segunda fase que motivó el viaje de escritores y aventureros a adentrarse en la península como fue el caso del novelista danés Hans Christian Andersen (1805-1875) que visitó España en dos ocasiones y escribió Viaje por España, 1862. En Inglaterra se desarrolló un importante foco de interés por lo español que dio lugar a una cuantiosa producción de literatura de viajes. Views in Spain de Edward Hawke Locker, 1824. Excursions in the Mountains of Ronda and Granada del capitán Rochfort

\footnotetext{
${ }^{317}$ En palabras de Richard Ford (1845: ix): "The key to decipher this singular people is scarcely European, since this Berberia Cristiana is at least a neutral ground between the hat and the turban, and many contend that Africa begins even at the Pyrenees".
} 
Scott, 1838. O The Bible in Spain or the Journey, Adventures, and Imprisonment of an Englishman in an Attempt to Circulate the Scriptures in the Peninsula, 1843, en que George Borrow describe su periplo durante la primera Guerra Carlista y habla por primera vez de los gitanos. Richard Ford (1796-1858) escribió Hand-Book for Travellers in Spain and Readers at Home, 1845, de gran éxito en su país alcanzando la novena edición en 1898 aunque en España no se tradujo hasta 1858. Ford vivió tres años en Sevilla y Granada, visitó la práctica totalidad de las capitales de provincia e innumerables pueblos guiado por el interés hacia lo característicamente español como la reciente Guerra de Independencia, los monumentos, la historia, los paisajes, la religión, el arte y las costumbres ${ }^{318}$. De su pasión por España surgió la necesidad de escribir un manual práctico en un momento de proliferación de guías de viaje, herramientas indispensables ante las posibles dificultades y peligros a salvar por el viajero del siglo XIX ${ }^{319}$. El manual de Ford se caracterizó por incluir, además de los datos para la logística propia del viaje, críticas y reflexiones personales acerca de su experiencia. El abanico de explicaciones sobre lo que se podía hacer y visitar en España, con la menor dificultad y el mayor grado de satisfacción posible ${ }^{320}$, tenían como fin despertar la curiosidad sobre un país descrito por el autor como una maraña de contradicciones dispuesta a ser descifrada por el intrépido viajero $^{321}$. A pesar del gran amor confeso que el inglés sentía por España su vivencia no dejaba de ser la de un extranjero de paso, sentado en su equipada diligencia y alojado por ilustres compatriotas residentes en el país.

\footnotetext{
${ }^{318} \mathrm{Y}$ que deja claro en el ambicioso subtitulo: Describing the Country and Cities, the Natives and Their Manners; the Antiquities, Religion, Legends, Fine Arts, Literature, Sports, and Gastronomy. With Notices on Spanish History.

${ }^{319}$ Ford (1845: vii) hacía referencia a este hecho en las primeras líneas del prefacio de su guía de viajes por España. "Of the many misrepresentations regarding Spain, few have been more systematically circulated than the dangers and difficulties which are there supposed to beset the traveller. This, the most romantic an peculiar country in Europe, may in reality be visited throughout its length and breadth with ease and safety, for travelling there is no worse than it was in France or Italy in 1814, before English example forced improvements".

${ }^{320}$ Ibídem. "This Hand-book attempts to show what may be known and what may be done in Spain, with the last difficulty and the most satisfaction".

${ }^{321}$ Ford, 1845: ix. "To see the cities, and know the minds of men, has been, since the days of the Odyssey the object of travel; but how difficult is it, in the words of 'the Duke' (Disp., Dec.13, 181), 'to understand the Spaniards exactly!' Made up of contradictions, they dwell in the land of the unexpected, le pays de l'imprévu, where exception is the rule, where accident and the impulse of moment are the moving powers, and where men, especially in their collective capacity, act like women and children".
} 
La de Ford fue una situación privilegiada conociendo su acomodada procedencia y su educación en el Trinity College de Oxford lo que le confería una alta formación intelectual que impregnó de cariz elitista sus impresiones. Un ejemplo es el fragmento: "En España, a excepción hecha de algunas grandes ciudades, faltan notoriamente bibliotecas, periódicos, cicerones [...] esos recursos que tan útiles suelen ser al viajero en otros países europeos" además de prestar atención a las "desabastecidas ventas de esta hambrienta tierra de los desinformados 322 ". Ford percibió el carácter de los habitantes rurales como gentes impetuosas, perezosas y resignadas, concluyendo que se trataba de un lugar de impase entre el exótico continente africano y la ilustrada Europa, "between the hat and the turban, and many contend that Africa begins even at the Pyrenees ${ }^{323 " . ~ P a r a ~ e l ~ i n g l e ́ s, ~ c o m o ~ t a m b i e ́ n ~ o c u r r i r i ́ a ~}$ a los siguientes exploradores extranjeros y autóctonos, la España del siglo XVIII y en concreto la rural, era una tierra de "rutina y costumbres [...]

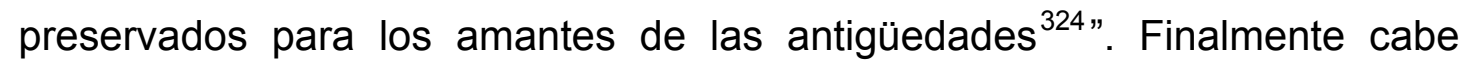
anotar que pese al sesgo elitista de sus comentarios, Richard Ford formaba parte de la minoría que huyó de la urbe. Desde su retiro en Heavitree, Inglaterra, escribió "Nos hemos dedicado a ruralizar y a rustificar desde que huimos de la irrespirable y pestífera ciudad", recoge lan Robertson en Breve historia del Manual para viajeros por España de Ford ${ }^{325}$.

También desde Francia llegaron escritores-exploradores en busca de la estela quijotesca. España fue la protagonista de numerosas guías de viaje entre las que destacan Nouveau Voyage en Espagne, ou Tableau de l'État Actuel de Cette Monarchie de Jean-François de Bourgoing, 1789. Itinéraire descriptif, historique et artistique de l'Espagne et du Portugal de Alfred Germond de Lavigne, 1866. L' Espagne de Jean-Charles Davillier e

\footnotetext{
322 Ídem: viii. "In Spain, some few large cities excepted, libraries, newspapers, cicerones, and those resources which so much assist the traveller in other countries of Europe, are among the things that are not; therefore the provident traveller should carry in his saddle-bags food both for mind and body, a supply of what he can read and eat, in the destitute ventas of this hungry land of the uninformed".

323 Ídem: ix.

${ }^{324}$ Ibídem. "This land and people of routine and habit are also potted for antiquarians, for here Pagan, Roman, and eastern customs, long obsolete elsewhere, turn up at every step in church and house, in cabinet and campaign, as we shall carefully point out".

${ }^{325}$ Texto introductorio a la edición española de Richard Ford, 2008: x.
} 
ilustraciones de Gustave Doré, 1874 o Espagne et Portugal: Manuel du voyageur de Karl Baedeker, 1900. El dramaturgo francés Alejandro Dumas (1802-1870) aprovechó el viaje a España con motivo de la boda del duque de Montpensier con la infanta Luisa Fernanda para escribir De París a Cádiz publicado en forma de carta en el periódico La Presse, 1847. George Sand escribió durante su retiro en la cartuja de Valldemosa Un hiver à Majorque. Spiridion, 1867. Y el político Alexandre Laborde de su paso por la embajada francesa en Madrid hacia 1800 ideó el proyecto Voyage pittoresque et historique de l'Espagne, con financiación estatal de ambos países y formado por ilustraciones que daban cuenta de los rincones de España. Uno de los aguafuertes es El modo de viajar en España de Louis François Lejeune (dibujante), Edme Bovinet (aguafuertista), Jean Duplessi- Bertaux (grabador).

En definitiva, resulta interesante constatar como una vez superada la distancia física del mito muchos de los viajeros decían sentirse defraudados con su experiencia en territorio español. Pues habían encontrado una España tosca, en ruinas, inculta y despoblada en comparación a la idealizada Edad de Oro vivida durante el auge del Al-Ándalus en la Edad Media. Esta era la impresión que Théofile Gautier plasmó en Voyage en Espagne. Tras los montes, 1843, cuyo sesgo peyorativo impregnaría la literatura apocalíptica y redentora hasta entrados el siglo XX ${ }^{326}$, opina del Molino.

En conclusión, la producción literaria, principalmente francesa e inglesa, en el afán por testimoniar la esencia del pueblo español aún intacta ante los procesos de industrialización, construyó todo un imaginario que interpretó el costumbrismo en clave idealizada, constituyendo una forma de entender la cuestión nacional en discursos posteriores y que, en muchas de las veces, supondría un problema por estar fundamentado sobre un mito romántico.

${ }^{326}$ Del Molino, 2016: 171. 


\subsubsection{Más allá del Quijote. La mirada autóctona de la España rural}

Además de la producción literaria extranjera, la cuestión rural ha estado presente en la tradición literaria española. Ya en tiempos de la expulsión de los jesuitas de Andalucía, Antonio Ponz recibió el encargo de hacer un inventario de los bienes restantes para lo cual recorrió el sur de la Península. Un periplo del que surgió Viage de España, ó Cartas, en que se da noticia de las cosas mas apreciables, y dignas de saberse que hay en ella, $1772^{327}$. Un siglo más tarde Eduardo Toda publicó Guía de España y Portugal. Con un mapa de la península y planos de las principales ciudades, 1892. Y Enrique De Mesa escribió La posada y el camino y a la vez que traducía los textos de Gautier y a Ford antes mencionados.

No solo en la literatura de viajes, en el resto de géneros literarios se acudía al entorno rural, una práctica que contribuyó a construir el imaginario de la España rural. Gustavo Adolfo Bécquer (1836-1870), durante su estancia en el monasterio de Santa María de Veruela en octubre de 1863, escribió Cartas desde mi celda, 1864, relatando la soledad que el forzado exilio ocasionaba en un hombre cosmopolita como él, resignado a experimentar el "paso de lo archicivilizado y moderno a la naturaleza casi primordial"328. Fue a partir de las ruinas del Moncayo que escribió esta serie de relatos mitológicos habitados por fantasmas y brujas, cultivando el género del misterio y de terror. Se trata de una de las primeras experiencias perceptuales del paisaje español aunque la suya sea una "mirada moderna [...] mitológica y esencialista [que] ignora todo el contexto económico y social. No mira realmente a las personas, sino lo que cree su substrato ${ }^{329 " . ~ L a ~ o b r a ~ d e ~}$ Bécquer, sumada a la de Juan Eugenio Hartzenbusch y José Zorrilla, fundamentó la construcción romántica del paisaje español por cuanto entendía los enclaves rurales más apartados de la meseta como contenedores de fósiles vivos a los que acudir en busca de la esencia

\footnotetext{
${ }^{327}$ Consultada la segunda edición de 1776.

${ }^{328}$ El Moncayo de las leyendas. En Rubio Jiménez, 1992.

${ }^{329}$ Del Molino, 2016: 157.
} 
nacional. Una idea que, siguiendo la explicación de Sergio del Molino ${ }^{330}$, con el tiempo se convirtió en hecho al abocar a los supervivientes de dichos enclaves a escenificar lo que se suponía debía ser su modo de vida. Ejemplo de esta circunstancia lo constituye la obra de José Ortiz Echagüe (18861980) fotógrafo interesado por la España más desconocida conforme a los preceptos de su época. De entre la tetralogía ${ }^{331}$ de volúmenes que publicó destaca Tipos y trajes (1930) dedicado a los perfiles más significativos de los habitantes de la España rural. Echagüe solía pedir a los retratados que vistieran sus mejores galas, una práctica que sumada a la técnica del pictorialismo lo sitúan como referente de la fotografía artística del siglo XX y alejado de la vertiente del documental.

La geografía moderna penetró en España en el último cuarto del siglo XIX. La labor de la Institución Libre de Enseñanza, fundada en 1876, fue trascendental en la promoción de una visión del "paisaje de cuño humboldtiano, con una decidida orientación geográfica, [de] interés científico [conjugado] con sensibilidad estética ${ }^{332}$ ". El acercamiento al paisaje que proponía la institución influiría en los nuevos modos de observar y admirar el paisaje propuestos por los escritores de la Generación del 98 que prestarían gran atención a la dimensión histórica y cultural del entorno natural. En consecuencia se experimentó un creciente interés por el entorno rural como testimonio del pasado y símbolo de la identidad nacional. Entre los nombres de esta ola de escritores que construirían una mirada autóctona sobre el paisaje español se encuentran Miguel de Unamuno (1864-1936), Antonio Machado (1875-1939) o Azorín (1873-1967). Los tres escritores son representativos de esa minoría de intelectuales que se adentró en la meseta castellana en busca de la esencia española, para posteriormente reflexionar sobre los beneficios morales de sus viajes catárquicos en busca de la reconciliación individual, y por extensión del ser humano, con la naturaleza. Este fue precisamente el motivo por el que Giner de los Ríos (1839-1915) consagró su vida a buscar "la pureza de España", esta era la rural donde

\footnotetext{
330 Ídem: 159.

${ }^{331}$ Los otros tres volúmenes se titularon España, Pueblos y Paisajes (1939), España Mística (1943) y España, Castillos y Alcázares (1956).

${ }^{332}$ Ortega, 2006: 37.
} 
decía encontrar "la dignidad de nuestros gustos y el amor a las cosas morales que brota siempre del contacto purificador de la Naturaleza ${ }^{333 " . ~}$ Brevemente, de los Ríos dejó un importante legado en el ámbito formativo y educativo. La Institución Libre de Enseñanza fue el paradigma del magisterio durante la II República y el germen de las Misiones Pedagógicas, plataforma desde la que entre 1931 y 1937 se desarrolló una importante cruzada cultural con la máxima de instruir a la España rural. Entre los nombres involucrados se cuentan algunos de los intelectuales más importantes del período republicano como Antonio Machado, María Zambrano o Luis Cernuda y Eduardo Ugarte. El proyecto comprendía el desplazamiento a los pueblos y aldeas con el objetivo de ofrecer el servicio de biblioteca, representaciones teatrales, actuaciones musicales, proyecciones de cine, exposiciones de arte y todo cuanto contribuyese a combatir el alto grado de analfabetismo de la España de la época. No obstante, cabe resaltar en el contexto de este apartado la suspicacia subyacente en la actitud de los artífices del proyecto llamando a la prudencia y al decoro ${ }^{334}$ de sus voluntarios ante el choque social que se producía en el encuentro con las comunidades rurales. Desde una perspectiva socio-cultural, el voluntariado de las Misiones Pedagógicas, como hiciesen los escritores noventayochistas, buscaba la restitución individual y colectiva- de unos lazos que se entendían previamente destruidos $^{335}$.

Los autores nacionales hasta el momento citados ejemplifican diferentes posicionamientos desde los que abordar la mirada, y consiguiente conceptualización del entorno rural español del siglo XIX y principios del siglo XX. Una clasificación que en opinión de Ortega Cantero ${ }^{336}$ diferencia tres corrientes en la literatura española del período dependiendo de la importancia del apartado descriptivo o sentimental. De este modo, en las obras de

\footnotetext{
${ }^{333}$ Reproducida en Otero, 2006: 26.

334 Ibídem.

${ }^{335}$ El sentimiento de reconciliación también motivó la participación de jóvenes universitarios en las iniciativas del Padre Llanos a través del Servicio Universitario del trabajo, SUT y del Trabajo Dominical en que se ofrecían experiencias en las zonas obreras y más pobres de los extrarradios urbanos. Unas iniciativas que respondían a la línea más populista del falangismo de ayudar a la sociedad más humilde, un saldar cuentas moral con la miserable realidad ocasionada por ellos mismos.

${ }^{336}$ Ortega, 2006: 67.
} 
Vicente Blasco Ibáñez (1867-1929), Emilia Pardo Bazán (1851-1921) y José María de Pereda (1833-1906) destaca el componente descriptivo como consecuencia de la estrecha relación con el estilo naturalista y el costumbrismo regionalista de estos autores. Una segunda en que el componente sentimental prevalece en las obras de Rubén Darío, el primer Valle-Inclán y también Juan Ramón Jiménez. $Y$ finalmente el equilibrio de ambos componentes se encuentra en la obra de la Generación del 98, puesto que sus integrantes se interesaron por la España rural creyendo encontrar allí el lugar en que se había detenido el tiempo, testimoniado en sus habitantes como valedores de la esencia nacional. Fundamento también de los debates regeneracionistas analizados a continuación.

\subsubsection{Detrás de donde todos miran. La contra-mirada a la España rural}

La realidad social de la España de principios del siglo XX distaba mucho de la del resto de países europeos, acrecentándose aún más las diferencias, en términos de desarrollo, entre núcleos urbanos y rurales. La imagen del mundo rural se vinculaba a un atavismo finisecular romantizado por nostálgicos y viajeros, algo que rechazaban aquellos intelectuales autóctonos cuya perspectiva constituye una contra-mirada que iba más allá para ofrecer una nueva versión de la ruralidad concebida. Las gentes miserables, la devoción religiosa y el deleite festivo fueron los ingredientes de la realidad castellana que interesó a Émile Verhaeren (1855-1916) y Darío de Regoyos (1857-1913), a José Gutiérrez Solana (1886-1945) y también a William Eugene Smith (1818-1978), este ya en plena década de los cincuenta.

"Las Hurdes o Jurdes tienen de antaño el prestigio de una leyenda, y cuantos van a ellas van, dese o no clara cuenta de ello, o a corroborar y aun exagerar la tal leyenda o a rectificarla. $Y$ no creo haber estado libre de este sentimiento". Esta es la declaración con que Miguel de Unamuno iniciaba el capítulo dedicado a la región extremeña en Andanzas y visiones españolas, 1922. 'La otredad' rural más representativa para el imaginario español de 
principios de siglo XX era la comarca de Las Hurdes. Una concepción a la que contribuyó la publicación de Las Jurdes: étude de géographie humaine, 1927, del hispanista francés Maurice Legendre (1878-1955) convertida, junto al filme de Buñuel, Las Hurdes. Tierra sin pan, 1933, en "soporte de un mito 337 ". No obstante a diferencia del mito de España alimentado por las visiones extranjeras antes descritas, esta vía giraba en torno a la llamada España negra resaltando en ella los componentes de atavismo, salvajismo y olvido. Si bien la intención de Legendre fue describir desde una perspectiva antropológica un lugar que entendía epítome del "honor de España ${ }^{338 ", ~ t a l ~}$ como transcribiese su colega de Unamuno, quien le acompañó en la travesía hurdana en 1914. Pero el arraigo de las creencias históricamente fundamentadas en la ignorancia hacia lo desconocido predominó. Un ejemplo de esta idea son los términos con que el escritor aborda el traspaso de los límites de El Casar de Palomero que califica de "excelente remanso" y "retiro de paz y remanso de sosiego" y donde los oriundos "nos informaban de las Hurdes y de los hurdanos, y pude observar que la leyenda empezaba ya alli ${ }^{339 " . ~ L a ~ r a z o ́ n, ~ a r g u m e n t a b a ~ d e ~ U n a m u n o, ~ s e ~ d e b e ~ a ~ " q u e ~ s u e l e ~ s u c e d e r ~}$ que aquellos que viven junto a una región famosa y de que se habla mucho suelen ser con frecuencia los que menos han sentido el acicate de ir a conocerla por sí". No obstante el dúo de viajeros estaba decidido a "entrar de una vez en las verdaderas Hurdes, es decir, en aquellas de que se nos ha dicho tantas veces que los hombres casi ladran, que se visten de pieles y huyen de los... civilizados!". Finalmente, en las aldeas del centro de la comarca encontraron la "visión de la miseria" de unas gentes "abandonadas de la Humanidad y de la Naturaleza", destinadas a arar unas tierras desagradecidas careciendo de bestias de carga. Pero sin embargo, lejos de huir, entonaban "quejas rituales" sobre una "vida mansa, humilde", relata Unamuno ${ }^{340}$.

\footnotetext{
${ }^{337}$ Del Molino, 2016: 117.

${ }^{338}$ De Unamuno, 1922: 111.

339 Ídem: 110.

${ }^{340}$ Tal y como les habían advertido en las Erías, la zona más remota de cuevas, encontraron enanos, cretinos y enfermos de bocio. La existencia de estas gentes era real, su estado se debía a la falta de horas de sol o la pureza de las aguas carentes de yodo, elemento que regula el tiroides en el crecimiento. Ídem: 116
} 
En definitiva, la miseria de los pueblos centrales de la comarca de las Hurdes fue vista por de Unamuno desde la dignidad de unas gentes resignadas a lidiar con el destino impuesto por la aridez de unas tierras que consideraban "su tierra hija", y es que "el hurdano es radical y fundamentalmente individualista. Como que por eso brega y pena allí y apenas emigra, y si emigra vuelve ${ }^{341}$ ". Finalmente, y en contraste con el estado de penuria del lugar, de Unamuno dejaba testimonio de la existencia de "gran cantidad de niños preciosos, sonrosados, de ojillos vivarachos, que he visto ${ }^{342 " ~ y ~ d e l ~ s a b e r ~ e s t a r ~ d e ~ l a s ~ g e n t e s ~ y ~ s u ~ h o s p i t a l i d a d . ~ E l e m e n t o s ~ q u e ~}$ nada tenían que ver con las fabulaciones peyorativas más difundidas sobre la comarca.

Adentrarse en la obra de Unamuno resulta imprescindible en el análisis de los trabajos que abordaron el entorno rural español en el siglo XX. La abundante producción del escritor vasco, en los términos que muestran sus escritos dedicados a Las Hurdes, revela una visión horizontal de la meseta castellana que interpretaba en clave identitaria, incluyendo desde el inicio no solo la descripción física de los lugares sino también el testimonio de sus habitantes, a los que denominó 'paisanaje'. De Unamuno compendió una serie de descripciones de lugares y personas que tenían como objetivo principal conocer, para a continuación revelar, la esencia nacional por vía de la 'intra-historia'. Los enclaves rurales fueron interpretados por de Unamuno como los contenedores de "la vida intra-histórica, silenciosa y continua como el fondo mismo del mar, es la sustancia del progreso, la verdadera tradición, la tradición eterna, no la tradición mentira que se suele ir a buscar al pasado enterrado en libros y papeles y monumentos y piedras ${ }^{343 " . ~ A ~ l o ~ q u e ~ a n ̃ a d i ́ a ~}$ "que lo más del idioma castellano está en su mayor parte enterrado. Está enterrado en el habla campesina y está enterrado en la terminología especial de los distintos oficios ${ }^{344 "}$. Una interpretación del espacio y de los habitantes rurales que sintetiza la producción literaria de la Generación del 98. La cual, a

\footnotetext{
341 Ídem: 119.

342 Ídem: 116.

${ }_{343}$ En http://www.cervantesvirtual.com/obra-visor/en-torno-al-casticismo-253798/html/. [Consultado el 20 de septiembre de 2018].

${ }^{344}$ Ibídem.
} 
su vez, fue llevada a cabo por un grupo de individuos ajenos al lugar: Azorín era valenciano, Unamuno vasco y Antonio Machado sevillano. Los tres profesaron un amor inmensurable hacia la España rural castellana, los tres aprendieron a mirar los campos y montañas de la península, no pudiendo sin embargo desprenderse de una visión procedente de la periferia, factor que cargaba sus miradas de juicios y sentimientos influyendo en la descripción de los escenarios rurales de sus obras. Como ejemplo, de Azorín se decía que atalayaba el paisaje como hiciesen los pintores impresionistas, aprehendiendo las sensaciones de color que le transmitía el conjunto natural contemplado. No obstante, la observación panorámica fue una práctica habitual entre los paisajistas románticos desde la primera mitad del siglo XVIII de la que deja testimonio Carl Gustav Carus en Cartas y anotaciones sobre la pintura de paisaje:

"El placer experimentado al contemplar desde una cima montañosa el entrelazamiento de los valles que acabamos de recorrer no se atenúa; antes bien, al mirar de cerca podemos sentir claramente, intensificada, la impresión de conjunto, porque en ella se repite y vuelve de alguna manera el deleite experimentado en ciertos lugares ${ }^{345 " \text {. }}$

En definitiva, la descripción, y con ello el ordenamiento, de la realidad natural circundante a partir del sentimiento experimentado de su conjunto armónico es la práctica que motivó la obra de los autores de la Generación del 98 , asunto sobre el que volveremos más adelante.

\subsection{La crisis finisecular y la reinvención de Castilla}

\subsubsection{El regeneracionismo en la eclosión de la conciencia nacional}

El imperio español forjado a raíz del descubrimiento de América en 1492 llegó a su fin en el siglo XIX. La pronta independencia de México en 1821 fue

\footnotetext{
${ }^{345}$ Carus, 1992.
} 
seguida por la de los estados de Sudamérica en 1824 y finalmente por las colonias de Cuba, Puerto Rico y Filipinas en 1898. Ciertamente la pérdida de las colonias, y sus respectivos mercados, no supuso un impacto significativo en el crecimiento económico español. Hacia 1880 la conexión comercial de la península con la isla suponía el $10 \%$ de todas sus exportaciones además que "el volumen de este comercio había disminuido a lo largo del siglo reorientándose hacia los mercados europeos, de tal manera que el impacto global de 1898 sobre las ventas exteriores españolas fue casi imperceptible ${ }^{346 " . ~ S i ~ b i e n, ~ q u e ~ n o ~ h u b i e s e ~ a p e n a s ~ c o n s t a n c i a ~ e n ~ l o s ~ i ́ n d i c e s ~}$ de producción y consumo ni tampoco en el producto por persona, no eximió de ciertos problemas económicos fruto de la indisciplina fiscal o la depreciación de la peseta.

A pesar que el Desastre de 1898 tuvo unas pérdidas económicas imperceptibles las consecuencias en el ámbito político e ideológico desataron una crisis que supuso el replanteamiento de los referentes identitarios y una merma de la confianza interna del país. Un sentimiento que sirvió para que ciertos sectores de la sociedad vasca y catalana, reivindicaran posicionamientos nacionalistas. Fraile Balbín resume la situación vivida en este momento, "el descalabro no fue, sin embargo, la pérdida de los mercados cautivos de ultramar, sino el clima político y los cambios institucionales causados por la acentuación del nacionalismo, que a su vez, facilitaron la marcha hacia la autarquía económica ${ }^{347 " . ~}$

El Desastre del 98 no fue la causa de la refundación del nacionalismo español, pues la conciencia nacional en España se "remonta a unos complejos antecedentes en la forma de protonacionalismo y nacionalismo dinástico" tomando "cuerpo definitivo con la llustración, [...] conclusión de esta larga fase protonacional que antecede a la revolución liberal", argumenta Blas Guerrero, advirtiendo además que:

\footnotetext{
${ }^{346}$ Fraile Balbín, P. “¿Fue realmente un desastre?”. En Juliá (Dir.), 1997: 204.

347 Ídem, 205.
} 
"La coyuntura noventayochista implica una notable dinamización, una significativa modernización $y$, en definitiva, una auténtica refundación para los nacionalismos españoles de signo global [sumados a] los proyectos de modernización económica y social, la reacción a los emergentes nacionalismo periféricos y la configuración de una respuesta conservadora a los cambios abiertos por el nuevo siglo ${ }^{348 "}$.

El nacionalismo aislacionista ${ }^{349}$, en términos político-económicos, y el mito nacional, en términos ideológicos, impregnaron los debates regeneracionistas que, desde el sentimiento de decadencia, abordaron el nuevo rumbo que debía emprender el país. Desde el ámbito político el regeneracionismo fue "una corriente ideológica, de orientación reformista, [...] estrechamente conectada con la realidad social recién aludida e impregnada, como ella, de una fuerte carga utópica ${ }^{350 " . ~ S i ~ b i e n, ~ r e m a r c a ~ J . ~ M . ~ J o v e r, ~ e s t a ~ v i ́ a ~ d e ~}$ pensamiento crítico se caracterizó desde los inicios por su imprecisión y ambigüedad. En primer lugar era producto de la actitud de una burguesía disconforme con el sistema y con la praxis política de la Restauración y en segundo lugar carecía de una organización interna. No obstante, la inquietud sobre el destino de la nación aglutinó a una nómina de intelectuales entre los que se encontraban Lucas Mallada, Joaquín Costa, Rafael Salillas y Ramón y Cajal. Además de Ángel Ganivet ${ }^{351}$, Ricardo Macías Picavea, Damián Isern, César Silió, Joaquín Sánchez de Toca o Santiago Alba. Un grupo espontáneo, y falto de coordinación también en opinión de Fernández Clemente, en que destaca Joaquín Costa ${ }^{352}$, jurista, político e historiador, empeñado en convertir en política el germen regeneracionista a través de propuestas de renovación agraria destinadas a mejorar el campo

\footnotetext{
${ }^{348}$ Blas Guerrero, A. "Refundación del nacionalismo español”. En Juliá (Dir.), 1997: 229.

${ }^{349}$ Un nacional-proteccionismo que no se iniciaba en 1898 pero si tuvo en estas circunstancias un importante detonante para su configuración.

350 Jover. J.M. "Regeneracionismo: los límites de la utopía”. En Juliá (Dir.), 1997: 213.

${ }^{351}$ De cuya obra destaca Libro de Granada publicado por la Cofradía del Avellano en 1899 donde traza un retrato de lo que Ganivet llama 'el alma de las calles' de los núcleos urbanos. Testimonio de la modernización arquitectónica a la vez que relato de la angustia producida por el choque entre lo viejo y lo nuevo buscando siempre la intrahistoria de España, entendida esta en el sentido utilizado por de Unamuno.

${ }^{352}$ La intención de Joaquín Costa fue formar un partido político de intelectuales. El 13 de noviembre de 1899 publicó el manifiesto Mensaje y Programa de la Cámara Agraria del Alto Aragón.
} 
aragonés ${ }^{353}$. Brevemente, la trayectoria política de Costa lo llevó a establecer una alianza con el movimiento de las Cámaras de Comercio lideradas por Basilio Paraíso y con la Liga Agraria de las clases propietarias castellanas que dirigía Santiago Alba, constituyendo así la Unión Nacional, grupo político a partir del cual pretendía llevar al Congreso las propuestas de mejora social. Sin embargo la actividad de la nueva formación pronto fracasó, teniendo en cuenta las dificultades habituales para la defensa de los intereses de los trabajadores del campo.

Desde una perspectiva general, las reflexiones y propuestas de los regeneracionistas más que descalificaciones globales al sistema liberaldemocrático constituían "una renovación y puesta al día del orden liberal español ${ }^{354 "}$ creado por la Restauración. Sin embargo, este mismo régimen gubernamental no permitía su concreción política, lo que propició que los postulados regeneracionistas se tiñesen de pesimismo. Este fue el tono que desde los inicios impregnaría la producción literaria de los autores del regeneracionismo y también de la Generación del 98, centrada en entender las causas del declive español en clave de conciencia nacional.

Nacionalismo y regeneracionismo se constituyeron en binomio recurrente a la hora de abordar la cuestión española en el período finisecular. De la derrota en Cuba y Filipinas surgieron infinidad de discusiones en torno a la identidad nacional en un momento en que España había quedado reducida a reliquia, lejos quedaba la bonanza económica y política de tiempos de los Reyes Católicos. El malestar generalizado hacia el sistema de la Restauración y la influencia francesa contribuyeron al sentimiento de decadencia en una sociedad regida por el atraso intelectual, la incultura y el analfabetismo a ojos del propio Joaquín Costa, quien atisbaba "sentimientos piadosos, de humanidad, de justicia, incluso una espiritualidad noble,

\footnotetext{
${ }^{353}$ Joaquín Costa era consciente que "Ios españoles tienen hambre de pan, hambre de instrucción, hambre de justicia" por eso proponía medidas prácticas a males reales, un modo de entender la acción política que lo caracterizó a lo largo de su trayectoria. Laín Entralgo, 1948: 422.

${ }^{354}$ Blas Guerrero, A. "Refundación del nacionalismo español”. En Juliá (Dir.), 1997: 229-234, 232.
} 
quijotesca ${ }^{355 "}$ en la sociedad del cambio de siglo. Dos caras de una misma realidad que constituyeron las dos vías en que discurriría la producción literaria y ensayística del período. Por su parte los regeneracionistas, como Lucas Mallada (1841-1921), ahondaban en la vertiente degenerada de las aldeas y los habitantes rurales, detallando la pobreza del suelo o el carácter perezoso, rutinario e ignorante de las gentes. Macías Picavea (1847-1899) describía España como un pueblo enfermo y atrofiado y Julio Senador (18721962) encontraba un país "irremisiblemente dañado por la ausencia de argón en el aire y por la pobreza en fosfatos del suelo ${ }^{356 " . ~ U n a ~ m u e s t r a ~ d e ~ l a ~}$ vertiente del regeneracionismo en que las descripciones desoladoras de paisajes y habitantes formaban parte de un primer estadio de análisis y reflexión en torno a la situación de la España finisecular. Paradigmático al respecto es el artículo que Joaquín Costa escribía en octubre de 1898 Muerte y resurrección de España, defendiendo la refundación de los pilares de la nación a partir de su propia decadencia. Una línea de pensamiento compartida por Azorín, como se lee en el fragmento de Madrid:

"Nos sentíamos atraídos por el misterio. La vaga melancolía de que estaba impregnada esta generación confluía con la tristeza que emanaba de los sepulcros. Sentíamos el destino infortunado de España, derrotada y maltrecha, más allá de los mares, y nos prometíamos exaltarla a nueva vida. De la consideración de la muerte sacábamos fuerzas para la venidera vida. Todo se enlazaba lógicamente en nosotros: el arte, la muerte, la vida y el amor a la tierra patria ${ }^{357 " .}$.

La localización física para estas formulaciones se encontraba en la meseta, en las dos Castillas, el valor simbólico de este espacio emanaba de su posición geográfica en el centro peninsular, su función práctica como granero del país y la concepción de sus gentes como ejemplo del temperamento español ${ }^{358}$, conforme enumera Laín Entralgo. Los modos de vida de los habitantes de Castilla y sus rasgos temperamentales eran un tema recurrente en las disertaciones de los regeneracionistas y literatos del

\footnotetext{
${ }^{355}$ Morales y Esteban. "Literatura del Desastre”. En Ídem: 238-239.

356 Ibídem.

${ }_{358}^{357}$ Reproducido en Laín Entralgo, 1948: 431.

${ }^{358}$ Laín Entralgo, 1945: 198.
} 
98, que encontraban allí la singularidad castiza del pueblo español, cualidad gestada entre los siglos XVI y XVII e interrumpida por el estallido de la Guerra de Independencia. De Unamuno escribió en una de sus lecturas históricas sobre Castilla:

"Castilla paralizó los centros reguladores de los demás pueblos españoles, inhibioles la conciencia histórica en gran parte, les echó en ella su idea, la idea del unitarismo conquistador, de la catolización del mundo, y esta idea se desarrolló y siguió su trayectoria, castellanizándolos... culmen del proceso histórico de España ${ }^{359 " .}$.

En conclusión, en la empresa de regeneración de la moral nacional posterior a 1898, Castilla se erigió en el lugar donde los literatos e intelectuales viajaban metafórica y literalmente para reencontrarse con su esencia, y por extensión la razón de ser del pueblo español. Sin embargo, una vez más, como también les había sucedido a algunos viajeros en busca del mito romántico español, lo que en verdad había, en palabras de Santos Juliá, eran "pueblos opacos y sórdidos y una raza doblada por la resignación, el dolor, la sumisión, la inercia ante los hechos, la idea abrumadora de la muerte ${ }^{360 " . ~ U n a ~ s e r i e ~ d e ~ e l e m e n t o s ~ p r e s e n t e s, ~ p o r ~ e j e m p l o, ~ e n ~ l a ~ o b r a ~ d e ~}$ Azorín. La decadencia social e identitaria finisecular iba a ser subvertida por los autores regeneracionistas y noventayochistas afanados en encontrar "los rasgos físicos, raciales, lingüísticos, históricos, etcétera, que -según se consideraba en esta época de crisis del positivismo- "conformaría la 'identidad', el 'espíritu', la 'psicología colectiva', peculiar e irreductible de cada pueblo $361 "$.

Finalmente cabe atender a los arquetipos que a ojos de los autores regeneracionistas y noventayochistas fueron tomados como paradigma de la esencia nacional. Un ejemplo fue la recuperación de la figura de Rodrigo Díaz de Vivar, El Cid Campeador, considerado "la más alta representación del pueblo español”, "el patrocinador de la honra patria, el portaestandarte de la

\footnotetext{
359 Ibídem.

360 Juliá, S. "Retóricas de la muerte y resurrección de España”. En Juliá (Dir.),1997: 242-243.

${ }^{361}$ Morales; Esteban. "Literatura del Desastre”. En Ídem: 238-239.
} 
independencia, el fuerte castillo de la nacionalidad ${ }^{362 ", ~ d e f e n d i ́ a ~ J o a q u i ́ n ~}$ Costa. La impronta del trayecto de El Cid fue también revisitada por de Unamuno quien dedicó Por las tierras del $\mathrm{Cid}^{363}$ a vindicar los escenarios de la historia de España. " $\mathrm{Y}$ cómo nos hablan las piedras sagradas de estos páramos!", exclama el escritor en su repaso por la Castilla reconquistada, la Medinaceli de Almanzor o la Numancia celtíbera. La figura de El Cid se une a la ya mencionada de Alonso Quijano, arquetipo protagonista de las disertaciones de Azorín.

\subsubsection{La Generación del 98 y el paisajismo español}

"El llano inhóspito de la altiplanicie castellana se ha hecho paisaje ante una mirada ordenadora y amorosa. Todos los elementos de la meseta -tierra, encinas, álamos, humildes poblados- componen una figura y dentro de ella están dotados de lugar, sentido y emoción singulares: encina grave triste pino, álamos llenos de vida intensa $y$ profunda ${ }^{364 "}$.

Castilla, seguida de la costa levantina y del norte peninsular, fue el enclave protagonista de las reflexiones de los regeneracionistas mencionados. Como eje conceptual y como motivo de reflexión persistió en la obra de los autores de la Generación del 98. Miguel de Unamuno, Pío Baroja (1872-1956) y Ramiro de Maeztu (1875-1936) originarios del País Vasco, Azorín de Alicante, los hermanos Machado de Sevilla y Ángel Ganivet (1865-1898) de Granda, además de los gallegos Ramón Menéndez-Pidal (1869-1968) y Ramón del Valle-Inclán (1866-1936). Todos ellos compartían el sentimiento de oquedad a la hora de abordar la cuestión de España. Ganivet hablaba de "abulia", de Unamuno de "marasmo" y Azorín decretaba una "depresión enorme de la vida"; Machado tachaba de "vieja y tahúr, zaragatera y triste" la España de principios del siglo XX, que en palabras de Menéndez Pelayo se adentraba en un "suicidio lento". Una incuria sentimental que desde una

\footnotetext{
362 Ibídem.

${ }^{363}$ Publicado en El Sol, 4 de septiembre de 1931. Reproducido en de Unamuno, 2014: 135137.

${ }^{364}$ Laín Entralgo, 1945: 28.
} 
perspectiva historiográfica contrastaba con el progreso científico de los proyectos de Santiago Ramón y Cajal (1852-1934).

Los autores noventayochistas respondían a un malestar que no sólo se vinculaba a la guerra de Cuba, sino también a la inconsistencia del sistema de la Restauración en el cual no encontraban la razón de ser nacional, ni histórica ni social. No obstante, todos ellos se mostraban dispuestos a diagnosticar el estado de excepción del período ofreciendo vías de solución. Como hemos visto, recurrieron en primera instancia a la tierra castellana, considerada punto de origen para su proyecto de regeneración de los fundamentos nacionales. El campo español se convertía en paradigma de la realidad nacional, por oposición a los núcleos urbanos, coincidiendo gran parte de los autores en rechazar Madrid, "pura actualidad visible de la historia de España, era a los ojos de todos [los noventayochistas] el espejo y el símbolo de la enorme displicencia que el curso de esa historia de España estaba produciendo en sus almas ${ }^{365 "}$. Es a partir de la condición periférica de todos estos autores como surge su condición de descubridores del paisaje castellano.

"De nuestro amor a España responden nuestros libros. Los libros de Unamuno, de Baroja, de Maeztu, los míos. No creo que tenga yo ni un solo libro, en los cuarenta volúmenes, ajeno a España. [...] Nosotros hemos sabido dar entonación lírica y sentimental a cosas y hombres de España". O "Hay que conocer la historia patria. $\mathrm{Y}$ hay que conocer-sintiendo por ella cariño- la tierra española". Declaraba Azorín en Madrid ${ }^{366}$, artífice de la identificación de estos autores bajo el apelativo Generación del $98^{367}$.

El sentimiento patriótico dominó la inquietud literaria de los autores del 98 cuya obra, producida entre 1895 y 1910 principalmente, contribuyó decididamente a la configuración del imaginario español en su vertiente

\footnotetext{
${ }^{365}$ Laín Entralgo, 1948: 435.

${ }^{366}$ Recopilado en Obras selectas (1943) y reproducido en Laín Entralgo, 1945: 167.

${ }^{367}$ Si bien, Azorín se habría apropiado del término acuñado en febrero de 1913 por Ortega con la intención de convertirlo en fecha epónima del grupo ante la coincidencia temporal en que publicaron su obra. En https://bit.ly/2oRE9O3. [Consultado el 15 de junio de 2018].
} 
crítica con la realidad contemporánea y que comprendía el rechazo a la vida moderna por cuanto tenía de mecanización de la existencia humana, en definitiva, una clara preferencia hacia el entorno rural en detrimento de los contextos urbanos e industriales ${ }^{368}$. "Es la ciudad odiable y odiosa del trajín social, de los cafés, de los casinos y los clubes, de los teatros, de los parlamentos, la odiosa ciudad de las vanidades y las envidias. Huyo de esta ciudad, en cuanto puedo. El campo es una liberación", sentenció de Unamuno en un fragmento de Ciudad, campo, paisaje y recuerdos, $1911^{369}$. Un temprano juicio que el autor desarrolló en sus ensayos compartido por el resto de autores de la Generación del 98. A lo que se suma el cuestionamiento de la historia de España y las formas de vida que perpetuaban la misma vertiente que estos criticaban. $\mathrm{Y}$, finalmente, el análisis de la peculiaridad psicológica del habitante español y el contexto sociocultural español en general.

La repulsa a la realidad contemporánea sustentó la visión negativa de los autores que, en opinión de Laín Entralgo, adoptaba tres formas ${ }^{370}$. Una primera basada en la pasividad al permanecer en el 'caparazón castizo', un casticismo histórico, por tanto, dirigido a perpetuar el inmovilismo. Una segunda opción que contemplaba, del mismo modo que hiciesen los intelectuales de la llustración, la apertura exterior situando a Europa en el horizonte. $Y$ en tercer lugar la creación de una 'casta íntima' que escogiese solo la parte noble del 'casticismo histórico' del que Don Quijote era su mayor trasunto. Atendiendo a la narración de la obra de Cervantes, su protagonista también experimentaba la derrota, la cual en los preceptos de los autores de la Generación del 98 era interpretada de la siguiente manera:

"La mística pasó y el humanismo español tuvo que ceder ante un realismo de hechos desnudos y un conceptismo de desnudos conceptos. España llegó hasta olvidar su propia cultura. Así, olvidado lo fecundo, desmoronado lo castizo, fatigada e inoperante, aislada unas veces, mimética otras fue viviendo España hasta que la 'casta

\footnotetext{
${ }^{368}$ De Unamuno, 2018 [1922]: 85-95.

${ }^{369}$ Reproducido en Ibídem.

${ }^{370}$ Laín Entralgo, 1948: 428.
} 
íntima', bajo forma de 'pueblo', comenzó a dar señales de nueva vida. Había sido la primera nuestra Guerra de la Independencia: 'El Dos de Mayo es, en todos los sentidos, la fecha simbólica de nuestra generación ${ }^{371 " \text { ". }}$

Este fragmento del libro Paisajes del Alma ${ }^{372}$ de Unamuno constata la preferencia por la tercera vía de que hablaba Laín Entralgo por la cual la estima negativa hacia el país se superaba por medio de la construcción de 'la casta íntima', requiriendo del viaje a los enclaves castellanos contenedores de la "realidad pura, sincera y auténtica ${ }^{373 " . ~ L a ~ c o n d i c i o ́ n ~ d e ~ l a ~ ' c a s t a ~ i ́ n t i m a ', ~}$ tan anhelada por los autores del 98, sería definida en torno al perfil 'del hombre quijotizado' de Unamuno:

"Triste, grave, pesimista, luchador resignado, impávido ante el ridículo, hombre de voluntad, más espiritual que racional, muy hijo del Medievo: habrá atravesado, a la fuerza, por el Renacimiento, la Reforma y la Revolución, aprendiendo, sí, de ellos, pero sin dejarse tocar el alma, conversando la herencia espiritual de aquellos tiempos que llaman caliginosos ${ }^{374 "}$.

Ante la intensidad del sentimiento patriótico e histórico desarrollado por cada uno de estos autores, la presencia del paisaje español adquiere las características analizadas al inicio de este capítulo, por las que fundamentalmente la descripción de la realidad contemplada se sustenta en la sensación experimentada por los sujetos-creadores.

Abordar la cuestión del paisajismo literario español conlleva detenerse de nuevo en el pensamiento y obra de Miguel de Unamuno, el más prolífico de los autores de la Generación del 98 en escritos que recogen la experiencia andariega a lo largo y ancho de España, la cual afirmaba "está por descubrir y sólo la descubrirán españoles europeizados. Se ignora el paisaje, el paisanaje y la vida toda de nuestro pueblo" ${ }^{375}$. Un pensamiento que también

\footnotetext{
${ }^{371}$ Ibídem.

${ }^{372}$ Recopilación de treinta y cuatro textos publicados en 1944 bajo el título Paisajes del Alma.

${ }^{373}$ Laín Entralgo, 1945, 95.

${ }^{374}$ Definía en el texto "Del sentimiento trágico". En Ensayos, II, 948. Reproducido en Laín Entralgo, 1948: 435.

${ }^{375}$ Ensayos I: 121. Reproducido en Laín Entralgo, 1945: 44.
} 
atraviesa las obras Paisajes, 1902, De mi país, 1903, Por tierras de Portugal y de España, 1911 y Andanzas y visiones españolas, 1922. La descripción de paisajes, el costumbrismo y la historia fueron constantes en su producción literaria, como consta en De mi país, 1903. Su vehemente dedicación al género le permitió evolucionar desde el historicismo decimonónico y los clichés del propio género hasta la constitución de un universo propio del territorio vivido, trasladado al papel mediante el recurso literario de las metáforas y la idea de la intrahistoria. El primero, nutrió su teoría estética del paisaje expuesta en 1911 en Paisaje teresiano. El campo es una metáfora ${ }^{376}$ en que defendía que "el universo visible es una metáfora del invisible, del alma, aunque nos parezca al revés". La metáfora como recurso retórico para la filosofía de la realidad cultivada por el autor era el resultado de un proceso de conocimiento científico conjugado con factores culturales y de estudio histórico que sobrepasaba el determinismo económico para poner en valor, y con ello dotar de significado, el enclave rural observado.

El segundo recurso, la atención a la tierra a través de su historia, constituyó el elemento diferenciador de la obra de Unamuno respecto a la del resto de noventayochistas, erigiéndose en posible vía de solución a la cuestión 'España' del período finisecular. La valoración de la historia en constante vínculo con la cultura supone un segundo estadio en la experiencia del paisaje, pues en el pensamiento de Unamuno historia y cultura son los responsables del placer estético que al dotar al paisaje de humanidad "lo convierten en parte del hombre, de su expresión y de su pasado 377 ", argumenta González Egido quien, por otra parte, teorizaba en torno a la idea de intrahistoria pues "para Unamuno, cada paisaje guarda un acontecimiento histórico, que lo recubre de signos y densifica la mirada que lo conoce: es otra forma, junto a la lectura literaria, de humanizar, de vivificar y en último término de humanizar la naturaleza visible ${ }^{378 " . ~ L a ~ l e c t u r a ~ l i t e r a r i a ~ f u e ~ o t r a ~ d e ~}$ las prácticas habituales de Unamuno, quien recurría a figuras retóricos para abordar la interpretación de un enclave natural. Del mismo modo que también

\footnotetext{
${ }^{376}$ Recopilado en de Unamuno, 2018 [1922]: 323-329.

377 Ídem: 29.

378 Ídem: 38.
} 
hiciese Santa Teresa (1515-1582) en Hacia el Escorial y De vuelta de la cumbre o Gustav Flaubert (1821-1880) en Ciudad, campo, paisajes y recuerdos.

En definitiva, Miguel de Unamuno invirtió gran tiempo en conocer en primera persona el paisaje castellano. "He recorrido casi toda España, he visitado treinta de las cuarenta y nueve capitales de sus provincias y muchas otras ciudades y villas" confesaba en De Salamanca a Barcelona. Siempre decantándose por los enclaves rurales en detrimento de los urbanos, "pasé por Madrid rápidamente, haciendo allí no más que una noche. No me place la corte y menos cuando no tengo nada definido y concreto que hacer en ella. ¡Vive allí la gente tan aislada! ${ }^{379 ” . ~ D e ~ h e c h o ~ l a ~ e s p e c i a l ~ a t e n c i o ́ n ~ a ~ l a ~}$ especificidad castellana ligada al escenario rural "de la monotonía cromática y las encinas centenarias de la meseta ${ }^{380 "}$ ya fue el tema principal de En torno al casticismo ${ }^{381}$ y ocuparía veintidós de los treinta y un paisajes de Andanzas y visiones españolas. Compendio de escritos en que reflexionaba sobre "la conciencia histórica de la españolidad, con sus características, austeridad y fortaleza, reflejadas en la figura de Felipe ${ }^{382 "}$.

La vivencia del terruño castellano y la pluralidad de los lugares visitados proporcionaban a de Unamuno la experiencia de realidad en un sentido profundo, incluso místico. En País, paisaje y paisanaje escribía a propósito de su experiencia durante el trayecto Ávila- Madrid:

"Aparecérseme como en niebla de tierra el paisaje, súbeseme éste al alma y se me hace alma, no estado de conciencia conforme a la conocida sentencia literaria. Alma y no espíritu psique y no penumbra; alma animal, ánima. [...] Siento que ese paisaje, que es a su vez alma, psique, ánima-no espíritu-, me coge el ánima como un día esta tierra

\footnotetext{
${ }^{379}$ De 'Salamanca a Barcelona' forma parte de Andanzas y visiones españolas, 2018 [1922], 216-227.

${ }^{380}$ González Egido “Introducción”. En de Unamuno 2018 [1922], 20.

${ }^{381}$ Serie de ensayos publicados en La España Moderna a lo largo de 1895 y recopilados en 1902.

${ }^{382}$ De Unamuno, 2018 [1922]: 50.
} 
española cuna y tumba, me recogerá -así lo espero- con el último abrazo maternal de la muerte ${ }^{383 "}$.

La intensidad emocional que desprendía la comunión personal del autor con el entorno natural constituye otro importante nivel semántico de su obra. Un ejemplo son las descripciones emotivas, francas e ingenuas del entorno rural de Paisajes del alma ${ }^{384}$ y La España moderna, 1889. González Egido establece, partiendo de la premisa del filósofo suizo Henri-Fréderic Amiel, que "todo paisaje es un estado de conciencia ${ }^{385 "}$. De este modo se entiende el sentido con que Unamuno concebía el sentir patriótico. "La primera honda lección de patriotismo se recibe cuando se logra cobrar conciencia clara y arraigada del paisaje de la patria, después de haberla hecho estado de conciencia, reflexionar sobre éste y elevarlo a idea", escribía en Frente a los negrillos ${ }^{386}$.

A modo de conclusión sobre el legado de Unamuno en relación a las reformulaciones de la cuestión 'España', se toman las palabras de Ortega que sentencia:

"Su gusto por el pasado, por la dimensión histórica del paisaje, su interés por los trabajos tradicionales y los lenguajes a ellos asociados, su utilización de fuentes literarias a menudo poco conocidas para conformar sus propias imágenes paisajísticas [constituyen] su idea de la continuidad nacional, su afirmación de que existe una continuidad histórica secular de la mentalidad nacional ${ }^{387 "}$.

Por su parte Azorín, hacía uso de una lente histórica en argumentaciones tales como, "iCuántas alegrías, cuántos dolores, cuántas esperanzas, cuántas decepciones han pasado por esta tierra durante siglos, a través de los años y de los años, a lo largo de las generaciones! ! $^{388 " . ~ E n ~ l a ~ e s t e l a ~ d e ~}$ Unamuno en busca de la llamada 'casta íntima', y a partir "de las

\footnotetext{
${ }^{383}$ Publicado en Ahora, 22 de agosto de 1933. Reproducido en de Unamuno, 2014: 29-32.

${ }^{384}$ Compendio de treinta y cuatro artículos escritos a partir de 1922 narrando sus viajes a través de la meseta castellana.

${ }^{385}$ De Unamuno, 2018 [1922]: 46.

${ }^{386}$ Texto que forma parte de Andanzas y visiones españolas. Ídem: 210-215.

${ }^{387}$ Ortega, 2006: 44.

388، “Un extranjero en España”. En Azorín, 1913: 312-316.
} 
manifestaciones culturales tales como la literatura (Calderón) y la pintura (Velázquez) $^{389 ",}$ Azorín centró su atención en el legado quijotesco para construir su visión sobre la cuestión nacional. Con el encargo del periódico El Imparcial en la conmemoración del tercer centenario de la obra de Cervantes, el escritor recorrió La Mancha en abril de 1905. Plasmó su periplo en el volumen La ruta de Don Quijote ${ }^{390}$, crónica del vaciamiento de la España rural y constatación del grado de arraigo del legado mitológico en la conciencia de los vecinos de los pueblos y aldeas, orgullosos de habitar en la misma localidad que Cervantes o de albergar las calles por las que paseó Bécquer. Mientras el escritor se preguntaba sobre la dimensión social del estamento campesino identificado con lo 'castizo'.

Azorín encontraba en el arquetipo de Don Quijote la dualidad del personaje admirable y del ser derrotado, trasunto del español de la época finisecular. Cabe apuntar que, aunque en menor medida, de Unamuno también reflexionó en torno al legado cervantino en Vida de Don Quijote y Sancho, 1914. Una producción que ilustra el interés literario por actualizar los referentes del Siglo de Oro, como sucediese en los pintores sumados a la causa regeneracionista analizados a continuación. Pero como advierte Jorge Urrutia, "no consiste su literatura en subsumirse en el pasado, sino en someter el pasado a la prueba del presente ${ }^{391 " .}$

Retomando la obra de Azorín, como también hiciese de Unamuno, el autor entendió el análisis del paisaje castellano como la suma del entorno natural y las gentes que lo habitaban. Un ejemplo es España. Hombres y paisaje, 1909, que contiene una de las descripciones más minuciosas del trabajador del campo español:

"Este hombre vive en el campo. Su casa está lejos de la ciudad. Su casa es pequeña, modestísima. La componen unos muros de argamasa, una cama, unas sillas, una mesa y algunos trebejos de cocina. Detrás de la casa hay un corralillo de cuatro paredes de

\footnotetext{
${ }^{389}$ De Unamuno, 1968 [1895]: 73.

390 Consultada la edición de Alianza Editorial de 2013.

391 Jorge Urrutia. "Prólogo". En Azorín, 2013 [1905]: 24.
} 
albarrada. Esto parecerá duro, molesto, cruel a los lectores acostumbrados al atuendo ${ }^{392, "}$

En cuanto al modo de vida de este estamento, Azorín argumentaba que:

"La vida del pobre hombre es muy sencilla: se levanta antes de que el sol salga; se acuesta dos o tres horas después de su puesta. En el entretanto, él sale al campo, labra, cava, poda los árboles, escarda bina, estercola, cosecha, sacha, siega, trilla, rodriga los majuelos y las hortalizas, escarza tres o cuatro colmenas que posee. No muele la aceituna porque no tiene trujal, ni pisa la uva porque no cuenta con jaraíz. Vende la aceitunas y la uva a algunos especuladores a como quieran pagársela ${ }^{393 " .}$

Y por lo que refiere a su nivel intelectual:

"[Los conocimientos] se reducen a bien poco: barrunta por las nubes si va a llover; sabe, poco más o menos, los cahíces de grano que dará ésta o la otra haza, y la porción de tierra que entra en la huebra que un par de mulas puede labrar en un día; conoce si una oveja está enferma o no lo está; tiene noticia de todas las hierbas y matujas del campo y de los montes el cantueso, el mastranzo, la escabiosa, el espliego, la mejorana, el romero, la manzanilla, la salvia, el beleño, la piorna; distingue por sus plumajes píos y trinos a todos los pájaros de las campiñas $[\ldots]^{394 " \text {. }}$

Los preceptos desde los cuales los autores de la Generación del 98 abordaron las interpretaciones sentimentales y teológicas de la tierra se sintetizan en las exclamaciones que cada uno de ellos pronunció. De Unamuno dijo aquello de "me duele España ${ }^{395 ", ~ m i e n t r a s ~ q u e ~ R a m i r o ~ d e ~}$ Maeztu confesaba que "mueve mi pluma el dolor de que mi patria sea chica y esté muerta ${ }^{396 "}$ en el volumen Hacia otra España, 1899. Una actitud, la de acudir a los enclaves naturales, y un sentimiento desprendido del ejercicio

\footnotetext{
392 En Azorín, 1920 [1909]: 116.

393 lbídem.

394 Ídem: 117.

${ }^{395}$ Expresión que da inicio al texto "Por capitales de provincia". En Azorín, 2018 [1922], 157164.

${ }^{396}$ Reproducido en Juliá, S. 1996. "Anomalía, dolor y fracaso de España". En Claves de Razón Práctica, 66, 10-21.
} 
observacional conjugados en el 'patriotismo del dolor' ${ }^{397}$ ' del que habla Ismael Saz y que recorrerá la obra de los autores de la Generación del 98. Bien a través de la expresión directa, bien a través de la construcción metafórica de la sensación elemental desprendida de la práctica contemplativa de la naturaleza, estos autores "inventaron un país moribundo, unos caminos desolados, unos pueblos desertados, unas callejas sombrías, oscuridad por todas partes $398 "$. Valle Inclán (1866-1936) se explayó en lo que llamó "la versión española de la vida civilizada y europea, por otro los residuos inoperantes y anacrónicos de los 'héroes clásicos' ${ }^{399 " . ~ U n a ~ v i s i o ́ n ~ t e ́ t r i c a ~}$ teñida del paisaje verde y negro de El Greco que también impregnaría la obra de Ramón Gómez de la Serna y Juan Ramón Jiménez.

Desde el sentimiento poético, Antonio Machado abordó el paisaje español basando su escritura en metáforas y adjetivaciones líricas para describir la realidad de la tierra. Pío Baroja completó a lo largo de su obra una colección de paisajes castellanos, con especial atención a la desolación del entorno y al desarrollo psicológico de sus habitantes, escenario en el que discurría el viaje catárquico del protagonista de Camino de perfección. Pasión mística, 1902. Un paisaje que el escritor concibió, como hiciesen de Unamuno y Azorín, desde la "historia que acaeció y la vida que bulle en la tierra contemplada", en palabras de Laín Entralgo que prosigue, "en las imágenes, en las metáforas, en los juicios estimativos de Baroja late una actitud del escritor ante la vida histórica del país a que el paisaje castellano pertenece ${ }^{400 "}$.

En conclusión, los periplos individuales de los escritores de la Generación del 98 a lo largo de Castilla en busca de la autenticidad patria contribuyeron a dotar de valor simbólico este espacio rural. $Y$ es que cada uno de ellos participó de la reformulación de los preceptos identitarios nacionales mediante un patriotismo andado, vinculado a la observación minuciosa y en primera persona de la realidad española a través del conocimiento de la tierra, de sus habitantes y de la historia de todos y cada uno de sus

${ }^{397}$ Saz, I.; Archilés, F., 2012: 264.

398 Juliá, S. "Retóricas de la muerte y resurrección de España”. En Juliá (Dir.), 1997: 242-243.

${ }^{399}$ Laín Entralgo, 1945: 137.

400 Ídem, 40. 
elementos constitutivos. En definitiva, el entorno social de la meseta castellana se convirtió en un espacio para la intelectualidad.

\subsubsection{La España negra en pintura}

Desde el ámbito pictórico el regeneracionismo finisecular estuvo teñido de color negro. Este puede ser un motivo recurrente para abordar las reformulaciones de lo español más allá de la esfera político-social proyectándolas en el ámbito artístico. Trazaremos una breve génesis, en términos ideológicos, del significado de lo negro en la producción artística agrupada bajo la denominación 'la España negra'.

En la construcción de la visión exótica de España no solo contribuyó la literatura de viajes de los autores extranjeros mencionados, sino también los artistas autóctonos que perpetuaron dos vías desde las que entender el costumbrismo vernáculo. Una identificada con el "casticismo amable y otra [con lo] bronco, crítico, 'negro'401". Teniendo la segunda vía su referente en Goya y en la Generación del 98, dicha producción de pensamiento adoptó un cariz nostálgico sobre un pasado de esplendor irrepetible.

El pintor Darío de Regoyos (1857-1913) residente en Bruselas ${ }^{402}$ desde 1879, y Emile Verhaeren (1855-1916), un poeta belga con quien mantenía amistad, publicaron La España negra de Verhaeren en la revista catalana Luz. Con un grabado de $\operatorname{Regoyos}^{403}$, el relato describe la experiencia de su viaje por tierras españolas. Concebida en forma de serial, la publicación tuvo poca repercusión en el sintomático año de su publicación, 1898. No obstante, en el contexto de este estudio, constituye el punto de partida para la conceptualización de la 'España negra', alejada de las visiones románticas y exóticas y en cambio centrada en la desolación y el estado de penuria de los

\footnotetext{
401 Ídem: 278.

402 Un factor importante en opinión de Calvo Serraller por dotar de cariz internacional la configuración de la 'España negra' sumada, obviamente, a la influencia de Verhaeren. En Juliá (Dir.), 1997: 277- 282, 278.

${ }^{403}$ Consultada la edición de 1924.
} 
rincones más alejados de la geografía española. Una visión de decadencia, a la par que cargada de crítica social. Como manifestaba el propio Verhaeren: "il faut vraiment un morceau de monocle rose devant l'œil pour voir l'Espagne en clair et en joie. L'Espagne est un pays mortuaire, essentiellement ${ }^{404 " .}$ Declaración que sintetiza la mirada idealizada de España por la mayoría de los viajeros del siglo XIX. Apenas unas décadas después, en 1920, José Gutiérrez Solana (1886-1945) publicó un libro con el mismo nombre, constatando la vigencia de esta nueva vía de testimoniar la realidad social de la España -rural mayoritariamente- de principios de siglo XX.

Desde un principio cabe tener en cuenta que "la identificación del color negro con España no fue, sin embargo, una cuestión estética, sino moral y política, como se puso en evidencia en un debate previo, el de la 'leyenda negra 405 '”. También sustentada en el descubrimiento internacional de los maestros de la pintura del Siglo de Oro español y por el valor que para muchos adquirió la obra de Goya (1746-1828), sobre todo sus Pinturas negras de la Quinta del Sordo, 1819-1923, sublimación de la paleta negra y parda.

“¡Paso libre al Norte!”406. Defendían los modernistas catalanes desde las páginas de Luz y Pel Ploma basándose en el ideario de Schopenhauer, Nietzsche o Wagner ${ }^{407}$. “iAncha es Castilla!”. Exclamaban los noventayochistas, desde los mismos postulados que años atrás les habían llevado a considerar a El Greco heraldo del alma castellana. Una

\footnotetext{
404 Jorge Urrutia. "Prólogo". En Azorín, 2013 [1905]: 18. "En verdad hace falta colocar un pedazo de lente rosa ante el ojo para poder ver la España en claridad y alegría. España es, esencialmente, un país fúnebre". Traducción de la autora.

${ }^{405}$ Calvo. "Ciudad y paisaje”. En Juliá (Dir.), 1997: 277- 282.

${ }^{406}$ Proclamaba José María Roviralta al final de su artículo 'La regeneración estética de España'. En Luz, noviembre de 1898. Un texto en que lamentaba la degeneración general de la sociedad española debido a la pérdida "de las energías, y la prueba de esto es esta misma indiferencia con que lo vemos todo y lo dejamos hacer todo; indiferencia que sólo el enfermo moribundo, que inútilmente se quiere arrancar de los brazos de una muerte que le aguarda. El cambio se impone [...] vengan estas energías, [...] venga un impulso para que el mundo no se detenga, $[\ldots]$ quédense atrás los espíritus afeminados y que siga en su correr veloz el que pueda. ¡Atrás la indiferencia! ¡Paso libre! ¡Paso al Norte!”.

${ }^{407}$ También del decadentismo belga de Verhaeren, Maeterlink o Ensor y del británico de Wilde, Crane, Whistler o Beardsley además de los nórdicos Kierkegaard, Grieg o Munch. Y en pintura referenciando a los antiimpresionistas Gauguin, Redon, Moreau o Puvis de Chavannes. Sentencia Calvo. Juliá (Dir.), 1997: 279.
} 
reivindicación que se producía justo en el momento en que la obra del cretense era reivindicada a nivel internacional coincidiendo con el fin del impresionismo y la emergencia del expresionismo. La nómina de artistas e intelectuales que se interesaron por la obra de El Greco es extensa. Manet y Rilke viajaron a España para contemplar sus obras en 1865 y 1912, respectivamente; Degas coleccionó algunas de sus piezas; Barrés le dedicó el monográfico Greco ou le secret de Tolède, 1912; también Meier Graefe escribía El Greco, 1909, expandiéndose la influencia del pintor, además de a los postulados de los expresionistas, a los simbolistas y modernistas. Asimismo, tempranamente, desde el interior de España, Benito Pérez Galdós y Emilia Pardo Bazán reconocían el valor artístico y moral de la obra del pintor. Tal fue el caso de Ignacio Zuloaga (1870-1945) coleccionista de su obra y desde el foco modernista catalán, Santiago Rusiñol, que dedicaba las reuniones en su casa de Sitges a la figura del pintor cretense.

Retomando las proclamas, en cierto modo ilustraban dos maneras de abordar un mismo objeto: la regeneración de España. Mientras unos miraban hacia el norte donde se encontraba el resto de Europa "enterrando España, centrifugándola en un estilo industrial, cosmopolita y urbano", los otros insistían en replegarse sobre sí mismos "en su intrahistoria, el yerto desierto castellano, epítome de espiritualidad frente al progreso, del campo frente a la ciudad $^{408 " . ~ L a ~ m e s e t a ~ c a s t e l l a n a ~ e n ~ p a r t i c u l a r, ~ c o m o ~ e l ~ r e s t o ~ d e ~ l a ~ E s p a n ̃ a ~}$ rural, constituiría el tema del paisajismo pictórico desde finales del siglo XIX hasta comienzos del XX. Pero a diferencia de otras escuelas europeas más interesadas en la experiencia visual producida por los nuevos escenarios urbanos, o la confrontación de estos con los rurales, la pintura española recalaba en la multiplicidad de formas del entorno y la vida rural autóctona.

La tradición paisajística española tuvo, en opinión de Calvo Serraller, escasa o nula repercusión en el mercado artístico, siendo sus artífices minorías selectas. No obstante el paisajismo se erigía como vía para el conocimiento de la historia, premisa fundamental de los noventayochistas

${ }^{408}$ Calvo. "Ciudad y paisaje”. En Juliá (Dir.), 1997: 277- 282, 281. 
como los mencionados de Unamuno o Azorín, lo cual dotaba de valor a esta práctica pictórica. E incluso llegó a desencadenar debates sobre la cualidad pictórica de los enclaves del norte por comparación a las llanuras castellanas o el Mediterráneo, tratados por los catalanes desde perspectivas realistas y metafóricas, o por valencianos deslumbrados por Joaquín Sorolla (18631923), máximo exponente de la España blanca frente a Zuloaga, trasunto de la España negra. Ambos pintores son representativos a su vez del regionalismo español, otra de las cuestiones reveladas con la crisis finisecular, y que constituiría el tema de numerosos debates.

Sorolla consiguió con sus grandes lienzos de la playa de la Malvarrosa transmitir la imagen de una Valencia, y por extensión España, "luminosa, saludable, optimista, superficial" pero también periférica "en la peor visión moral de la periferia mediterránea, según los del 98 , la del Levante ${ }^{409 "}$. La crítica de Calvo Serraller se entiende en la línea de las disquisiciones noventayochistas en torno a la razón de ser de la unidad nacional para la cual "el paisaje y su redefinición moral [se erigía en] reflejo de lo que era y debía ser la identidad española ${ }^{410 ", ~ y ~ o b v i a m e n t e ~ n o ~ t o d o ~ e l ~ p a i s a j e, ~ s o l o ~ e l ~}$ castellano. Los postulados noventayochistas convergían con la paleta negra y verde de Ignacio de Zuloaga, seguido de Julio Romero de Torres, Hermenegildo Anglada Camarasa, José Gutiérrez Solana y el joven Picasso. En resumen, Zuloaga es, de entre los pintores finiseculares, el máximo exponente de 'la España negra', integrado en la élite intelectual parisina y admirador de Ribera, Velázquez, Goya y El Greco, se interesó por el paisaje castellano, elementos que lo conectan directamente con los componentes de la Generación del 98.

\footnotetext{
${ }^{409}$ Características que le reportaron la crítica de los noventayochistas que lo acusaban de falsear la imagen genuina de España. Valle-Inclán y de Unamuno le recriminaban haber "creído observar que la preocupación dominante de nuestro pueblo es el goce de la mujer, o, si se quiere, la lascivia" menoscabando "lo trágico y lo triste de nuestra historia". Forjándose cada vez más las dos interpretaciones de la España de la época en que la defendida por los noventayochista se erigía como la real y comprometida, mientras que la de Sorolla abogaba por lo popular. Calvo. En Juliá (Dir.), 1997: 278.

${ }^{410}$ lbídem.
} 


\subsection{Aspectos fundamentales de la España rural}

\subsubsection{La dimensión social del entorno rural}

"Los individuos obramos de manera diferente en función de los contextos que nos rodean ${ }^{411}$.

El paisaje rural mirado por todos estos intelectuales y artistas revela una dimensión social y cultural al ser también el hogar de comunidades rurales, "whose lives and daily activities give this space its meaning and value ${ }^{412 "}$. Es oportuno rescatar la hipótesis sobre el entorno rural como espacio de definición y reconocimiento de formación social para tratar de definir el perfil del habitante rural.

Desde un punto de vista social, el campesinado se congrega alrededor de la comunidad aldeana englobada a su vez en la comunidad local, entendida esta última como "grupo social basado en un sistema de lazos y relaciones; intereses comunes, pautas compartidas y normas y valores aceptados; [mostrando una] conciencia de ser distinta de los demás grupos ${ }^{413 "}$. Atendiendo al criterio de clasificación en un orden social escalonado, la comunidad aldeana se encuentra en el rango inferior de la comunidad local. El diccionario de la Real Academia de la Lengua Española la define en términos de "pueblo de escaso vecindario y, por lo común, sin jurisdicción propia" conformado por "habitantes miembros de familias que trabajan en explotaciones campesinas" propiedad de un terrateniente local. Casas Viejas en Benalup de Sidonia (Cádiz) o los asentamientos de la comarca de Las Hurdes en Extremadura bajo la jurisdicción de La Alberca (Salamanca) son ejemplos de subordinación de núcleos aldeanos a comunidades locales.

Y desde la lógica del ciclo económico, Boguslaw Galeski define el modo de explotación campesina como aquel sistema de producción basado en la

\footnotetext{
411 Serna; Pons, 2005: 5.

${ }^{412}$ Fowler; Helfield, 2006: 6.

${ }^{413}$ Hiller, A. (1955). "Definition of community: areas of agreement". En Rural Sociology", vol. XX, 119. Reproducido en Galeski, 1977: 133.
} 
identificación de la empresa agrícola en que una comunidad aldeana, entendida como un todo funcional, "satisface sus necesidades básicas dentro de su economía doméstica", acostumbrando a intercambiar bienes y servicios, una práctica habitual donde "la ayuda mutua regular, el trabajo de grupo y la propiedad común de los medios de producción" culminan, las más de las veces, en cooperativas de producción, comercialización o de servicios confiriéndole a la comunidad aldeana el carácter de "unidad compacta de producción ${ }^{414 "}$.

Desde una perspectiva sociológica, el estrecho contacto del ser humano con la naturaleza constituye el rasgo identificativo del entorno rural. Aunque Galeski no determinó el grado de implicación de este factor en la constitución de la personalidad de sus habitantes y las relaciones interpersonales que mantienen, sí concluyó que "la comunidad aldeana es un grupo primario. Las relaciones entre sus habitantes se basan en los contactos personales [...] persistentes y no esporádicos ${ }^{415}$ ", por oposición al anonimato y multiplicidad de los vínculos personales desarrollados en los núcleos urbanos. En la naturaleza personal, y la abundancia de las relaciones de la comunidad aldeana, influye significativamente la opinión del grupo sobre el comportamiento de familias e individuos.

"Los fuertes lazos de parentesco existentes entre las familias que forman la comunidad, los firmes ligámenes de vecindad, el sistema ramificado de relaciones socio-económicas, la existencia de muchas instituciones aldeanas específicas y otros rasgos que constituyen la comunidad aldeana como grupo primario, [son] factores que constituyen las especiales condiciones ambientales de las que la familia campesina, con sus funciones distintivas culturales, educativas y de seguridad social, deriva su existencia y durabilidad ${ }^{416, "}$.

Por otro lado, cabe añadir que la vida cultural y el entretenimiento de los habitantes rurales se reducían a "ceremonias asociadas con las estaciones del año, el inicio o el fin de las labores agrícolas, la realización común de

\footnotetext{
414 Ídem, 147.

415 Ídem, 140.

416 Ídem, 113.
} 
ciertas tareas hechas en tertulia y las diversiones organizadas por las asociaciones y organizaciones sociales del pueblo ${ }^{417 "}$. Y que forma parte de la representación de las comunidades rurales de Las aguas bajan negras de José Luis Sáenz de Heredia, 1948, ¡Aquí hay petróleo! De Rafael J. Salvia, 1956 o Un indiano en Moratilla de León Klimovsky, 1958.

De entre los antropólogos españoles que han estudiado la cuestión rural Luis Enrique Alonso, José María Arribas y Alfonso Ortí ${ }^{418}$ ofrecen una visión sesgada -a diferencia de Galeski, Fowler y Helfield centrados en las particularidades del entorno rural en sí mismo- al abordar las "convenciones sobre el desarrollo económico [del] mundo agrario" desde su condición "residual, atrasado o marginal" respecto al núcleo urbano. La suya es una definición del entorno rural por contraste al urbano que perpetua la categorización del espacio y sus habitantes en la línea de las acepciones que ofrece la RAE de los términos 'pueblerino' en referencia a "aquella persona poco refinada en sus modales o en sus gustos, o carente de amplitud de ideas o puntos de vista" y 'aldeano' como "aquello rudo o tosco". Una categorización del estamento rural en detrimento de un estrato superior ocupado por el habitante de la ciudad, el 'ciudadano', “aquella persona considerada como miembro activo de un Estado, titular de derechos políticos y sometido a sus leyes". En cuyo reverso se encuentra el campesino caracterizado por su "baja integración como sujeto organizado, producto de la desestructuración básica que supone la pequeña propiedad agraria ${ }^{419}$ ". Entiéndase esta definición en un sentido político en que el sujeto campesino desarrollaría una conciencia de clase y haría prevalecer sus derechos como ciudadano. Sin embargo, la ausencia frecuente de este carácter en el estamento campesino ya llevó a Karl Marx a utilizar el símil del campesino como una patata dispuesta en un saco constituyendo una "suma de unidades del mismo nombre ${ }^{420 "}$.

\footnotetext{
${ }^{417}$ Ibídem.

${ }^{418}$ En su artículo Evolución y perspectivas de la agricultura familiar: "de propietarios muy pobres" a agricultores empresarios", 1991.

${ }_{419}$ Alonso; Arribas; Ortí, 1991: 35.

${ }^{420}$ Marx, 2003 [1852]: 115.
} 
En su artículo Alonso, Arribas y Ortí defienden la imposibilidad de referirse a la conciencia campesina -como pensamiento práctico- siendo más oportuno hablar de mentalidad campesina entendida en el sentido de la Nueva Historia francesa "como un estado o estructura mental invertebrada constituida por visiones del mundo heredadas de un lejano pasado y reconocidas tanto por el grupo en que se originan como por el resto de la sociedad global ${ }^{421 " .}$ Concluyen los autores que, en particular, la mentalidad rural está basada en "la oposición y en la identidad, en el sí mismo y el otro ${ }^{422 " . ~ D e ~ a h i ́ ~ q u e ~ e l ~}$ campesinado como clase, constituya una formación social profundamente homogénea en sus rasgos básicos. Aunque la incidencia del desarrollo del capitalismo ha provocado en ella, de todos modos, cierta estratificación y, por lo tanto, heterogeneidad.

Llegados a esta fase de la argumentación en torno a las diferentes perspectivas y demás posicionamientos desde los que historiadores y sociólogos han interpretado la cuestión rural, resulta oportuno rescatar la línea de pensamiento desde la que Ramón J. Sender en comparación a las tesis de Alonso, Arribas y Ortí. En la crónica del 'caso de Casas Viejas' publicada en 1934 Sender se refiere a los campesinos en los siguientes términos: "Y dentro de la total ineducación política del jornalero y de su natural individualismo. Cada individuo que se sienta capaz, intentará hacer su revolución. Cada aldea, cada pueblo que tenga armas y recias hambres, querrá su comunismo libertario ${ }^{423}$ ". Sin embargo, teniendo en cuenta la naturaleza de los sucesos de Casas Viejas y las circunstancias de proximidad espacial y temporal en que el periodista redactó estas líneas queda manifiesta la conciencia crítica del estamento campesino que se alzaba contra el sistema feudal que le constreñía. En el caso de Casas Viejas la revuelta se produjo en respuesta al subsidio que percibían, una "limosna [que] no hace sino arrebatarles [...] lo único que les quedaba: la dignidad de su trabajo y de su jornal ${ }^{424 ",}$, en palabras de Sender.

\footnotetext{
${ }^{421}$ Ariès, 1988 [1954]: 473-474.

422 Wilden, A. (1970). Sistema y estructura. Madrid: Alianza, 60. Reproducido en Alonso et alii, 1991: 37.

${ }^{423}$ Sender, 2016 [1934]: 25.

424 Ibídem.
} 
La disparidad de miradas aquí contempladas pone de manifiesto la multiplicidad de 'ojos deformados', de que hablaba Cristina García Rodero, que han abordado la cuestión rural. Además "Spain is a place of geographical differences ${ }^{425}$ ", una idea que en el contexto de análisis del entorno rural introduce el problema de la heterogeneidad de las comunidades rurales dependiendo de su localización. No obstante, debido a la imposibilidad de desarrollar una argumentación en torno a las diferencias compositivas de las múltiples comunidades rurales españolas, por no ser este un trabajo versado en el campo de la sociología, cabe concluir con las palabras de Alonso, Arribas y Ortí que coinciden en destacar la fuerte cohesión de la comunidad rural:

"Por el parentesco y el sentimiento de pertenencia de los miembros contenidos en ella [como] principal argumento simbólico que sirve para armar el discurso campesino. El apego a la tierra, el patrimonialismo, el miedo al progreso, la sacralización de la propiedad, la tendencia a convertir al campesinado en "el pueblo" en general -entendido como la gente común y humilde de una población-, son expresiones de ese cierre simbólico de la mentalidad campesina que lo convierte todo en un enfrentamiento permanente entre la comunidad y el exterior

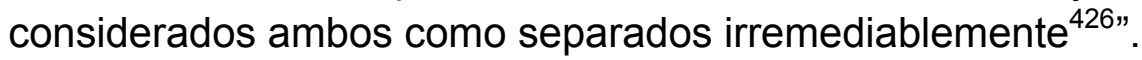

\footnotetext{
${ }^{425}$ Richardson, 2012. "España es un lugar de diferencias geográficas". Traducción de la autora.

${ }^{426}$ Alonso et alii, 1991: 37.
} 


\section{El cine rural español, 1950-1959}

A lo largo del siglo $X X$ el espacio rural ha servido de escenario a narraciones cinematográficas que, aun siendo una producción minoritaria, han sido una constante desarrollando, por ejemplo, el género del drama rural. La cinematografía española y la fotografía en el siglo XIX, y anteriormente la tradición pictórica y literaria, han dejado constancia del paisaje español, siendo en la década de los años cincuenta donde se concentra una de las producciones más cuantiosas de cine rural. Una circunstancia enmarcada en el contexto de viraje diplomático del régimen franquista puesto que el país había perdido el rumbo y, como ocurriese en el período finisecular, urgía de un corpus referencial que impulsase su resurgimiento.

A finales de los años cincuenta se empezaba a concretar la reactivación económica del país. El Plan Nacional de Estabilización de 1959, los posteriores planes de desarrollo, 1962 y 1963, y la campaña de '25 años de paz', 1964, sustentarían la nueva fase de desarrollismo concentrada, principalmente, en los núcleos urbanos mientras el campo español sufría las consecuencias del general empobrecimiento y del éxodo rural factores que ocasionaron una transformación espacial como preámbulo a la modernización del país. El campo español quedaba atrás en pro de las ciudades y capitales de provincia como constata el cambio generalizado de escenario de las ficciones de la década de los años sesenta. En las urbes se localizó el cine de la etapa del desarrollismo. La tía tula, Miguel Picazo, 1964, o Nueve Cartas a Berta, Basilio Martin Patino, 1965, y ya anteriormente Cielo Negro, Manuel Mur Oti, 1951, o Calle Mayor, Juan Antonio Bardem, 1956. Si bien es cierto, la década de los 70 y 80 supuso una vuelta al espacio rural. El bosque de Furtivos, 1975, o el pueblo segoviano de El Espíritu de la colmena fueron interpretados como metonimia de la deriva del país tras la letargia de casi cuarenta años de régimen franquista. Las perspectivas críticas teñidas de nostalgia desde las que se miró el paisaje rural en estos años hacen de este espacio el lugar de confrontación de lo vetusto frente a lo moderno como sucede en Tasio de Montxo Armendáriz, 1984. Una mirada crítica sobre la realidad del campo español que adquiere su máxima en la adaptación 
cinematográfica de Mario Camus de la novela de Miguel Delibes, Los Santos Inocentes, 1985.

\subsection{Los usos cinematográficos del espacio, el paisaje y el territorio}

Los treinta y cinco proyectos de cine rural producidos en la década de los cincuenta se concretan en unos tratamientos formales del uso cinematográfico del espacio rural. La carencia de focos nacionales que aborden esta cuestión nos conduce a referenciar los trabajos de los núcleos anglosajones. Denis Cosgrove en Social Formation and Symbolic Landscape sugiere que esta carencia se debe a que "landscape is linked to economic exploitation, this may explain why Spain is not readily associated with a landscape tradition in the way that Italy, Great Britain, the Netherland and Germany are ${ }^{427}$." Por su parte Graeme Harper and Jonathan Rayner en Cinema and Landscape defienden que este objeto de estudio "needs to acknowledge different kinds of environments ${ }^{428}$ ", en otras palabras la complejidad de los usos espaciales y sus significados trasciende del ámbito artístico y cinematográfico al sociológico, político y geográfico constituyendo en suma una entidad cultural.

El marco teórico de este trabajo se articulo en torno a las siguientes tesis fundamentales. La primera consiste en la identificación de las formas que adoptan los usos espaciales. El trabajo del historiador Martin Lefebvre constituye la referencia teórica fundamental para la definición de los tres estadios en que artísticamente se expresa la cuestión espacial y que determinará la ordenación de los casos de análisis propuestos. En Landscape and Film, que a su vez parte de los razonamientos de Anne Cauquelin en L'Invention du paysage, 1989, el autor establece la división básica de las formas que adopta la representación del espacio: setting y

${ }^{427}$ Cosgrove, 1998. Reproducido en Davies, 2012: 16. "El paisaje se relaciona a la explotación económica, lo cual puede explicar porqué España no se ha asociado con la tradición paisajística en el modo en que lo hicieron Italia, Reino Unido, los Países Bajos o Alemania". Traducción de la autora.

${ }^{428}$ Harper; Rayner, 2010: 13. 
landscape. El primer término se refiere a "the space of story and event: it is the scenery of and the theatre for what will happen ${ }^{429,}$. De hecho en cine toda unidad mínima de significado requiere de un setting definido por el encuadramiento de la cámara, la duración temporal del mismo y el trabajo de montaje. $Y$ el segundo, landscape, constituye el estadio que surge de la emancipación del espacio de la función de marco espacial. La multiplicidad de representaciones y significados que adoptan las expresiones del paisaje, originarias del ámbito pictórico, trascienden los límites del soporte artístico asentándose en el imaginario colectivo, propiciando de este modo su análisis desde perspectivas socio-culturales vinculadas al estudio de los procesos de construcción identitaria. En este punto cabe recordar que, desde la década de los noventa la historiografía centrada en analizar la construcción discursiva de las naciones a través de procesos de creación ideológica e imaginativa, ha renovado su interés por los productos culturales ${ }^{430}$. Entre ellos destaca el cine como agente constructor de lo que Benedict Anderson llama "comunidades imaginadas" (2005), por lo que el vínculo entre la idea de nación y la elaboración de narraciones es clave para entender los discursos de las culturas nacionales ${ }^{431}$.

Finalmente, Martin Lefebvre distingue el estadio territory, el cual, se relaciona a los postulados de la geografía cultural que lo entienden como la suma de la interacción del espacio con el ser humano que lo habita.

"[Landscape] as a set of relations which are woven between human being and the land: agriculture, hunting, fishing, [...]. These relations are themselves reliant on vast economic and political stakes and possess otherwise imaginary and identifying aspects whose importance cannot be overstated. When these relations describe the ways one has of inhabiting the land owning it, fighting for it, or working on it, the land tends to be represented in terms of territory ${ }^{432 " .}$

\footnotetext{
${ }^{429}$ Lefebvre, 2006: 22. "El espacio de la historia y los acontecimientos: es el decorado del teatro de lo que allí ocurra". Traducción de la autora.

${ }^{430}$ García Carrión, 2007: 10

${ }^{431}$ García Carrión, 2013b: 117.

432 Ídem: 53. "El paisaje como conjunto de relaciones entretejidas entre los seres humanos y la tierra: agricultura, caza, pesca, [...]. Estas relaciones, por si mismas, dependen de una vasta economía e intereses políticos, las cuales por otro lado poseen aspectos del imaginario y la identidad cuya importancia no puede sobrestimarse. Cuando estas relaciones describen
} 
A su vez, el historiador conviene la compatibilidad del estadio territorio con el de paisaje puesto que ambos casos se constituyen en torno a su propia especificidad y del alcance de las relaciones de las comunidades con la tierra que habitan.

La segunda de las tesis consiste en la incidencia de la mirada que convierte el espacio rural, como es el caso, en paisaje. "The form of landscape is thus first of all the form of a view, of a particular gaze that requires a frame. With that frame nature turns into culture, land into landscape ${ }^{433 "}$. Partiendo de la genealogía pictórica del paisajismo, Lefebvre reflexiona sobre la incidencia del sujeto-creador cuya mirada ordena el entorno y lo hace paisaje. En esta línea Harper y Rayner sostienen que "the cinematic landscape is the imposition of order on the elements of landscape, collapsing the distinction between the found and the constructed ${ }^{434}$ ". Martin D' Lugo prosigue a raíz de su definición de cinematic ethnoscapes, "while often appearing to express only the aesthetic choices of individual filmmakers, these cinematic ethnoscapes over time came to embody competing ideologies that have shaped much of Spanish cultural history ${ }^{435 " . ~ E n ~}$ definitiva, se concluye el valor del paisaje como constructo cultural el cual "play in identity formation either by way of ideology or their connection to national traditions in the fine arts and cultural matters at large ${ }^{436,}$.

La incidencia, que Harper y Rayner llaman intencionalidad, del sujetocreador "relate[s] the image to certain historical conventions of landscape

los modos en que se ha habitado la tierra, poseyéndola, peleándola, o trabajándola, la tierra tiende a ser representada en términos de territorio". Traducción de la autora.

${ }^{433}$ Lefebvre: XV. "De este modo la forma del paisaje es principalmente la forma de la mirada, de una mirada particular que requiere de un marco en el cual naturaleza se convierte en cultura y la tierra en paisaje". Traducción de la autora.

${ }^{434}$ Harper; Rayner, 2010: 13. "El paisaje cinematográfico es la imposición del orden de los elementos del paisaje en que colapsan las diferencias entre los encontrado y lo construido". Traducción de la autora.

435 Ídem: 93. "Cuando comúnmente parece que expresa solamente las elecciones estéticas de cada realizador, los "ethnoscapes" cinematográficos con el tiempo se convierten en un compendio de ideologías que han formado parte de la historia cultural española". Traducción de la autora.

${ }^{436}$ Lefebvre, 2006: IX. "Juega un papel en la formación identitaria tanto en la vía ideológica como en su conexión con la tradición nacional de las bellas artes y demás intereses culturales en general". Traducción de la autora. 
painting ${ }^{437 ", ~ a s i ́ ~ c o m o ~ a ~ u n a ~ m u l t i p l i c i d a d ~ d e ~ r e f e r e n c i a s ~ i d e o l o ́ g i c a s ~ y ~ s o c i o-~}$ culturales, que concluye en la idea que las manifestaciones del paisaje nunca son neutras. Henri Lefebvre en The Production of Space profundiza en la intencionalidad del sujeto estableciendo una gradación para determinar la forma que adopta la experiencia del paisaje "as perceived -the spatial practice, as conceived -representation of space, and lived -spaces of representation ${ }^{438 " \text {. }}$

La tercera tesis se fundamenta sobre la complejidad del paisaje como entidad cultural. Además de la multiplicidad de disciplinas implicadas en la tradición representativa, la diversidad de miradas que experiencian el paisaje y de significados y, finalmente, la naturaleza del fenómeno como constructo cultural, define el paisaje no solo como testimonio de los agentes participantes en cada contexto si no que funciona como "a consequence of the various practices surrounding and investing in the resources [the landscape] provides ${ }^{439}$ ". Una idea que converge con la tesis Richardson sobre el cine el cual "has interacted with the local politics that cultural products inevitably register ${ }^{440 " . ~}$

"For more than 25 years I have been trying to understand and explain that aspect of the environment that I call the landscape. I have written about it, lectured about it, travelled widely to find out about it; and yet I must admit that the concept continues to elude me. Perhaps one reason for this is that $I$ persist in seeing it not as a scenic or ecological entity but as a political or cultural entity, changing in the course of history ${ }^{441 "}$.

\footnotetext{
${ }^{437}$ Ídem: XIX. "Relaciona la imagen con ciertas convenciones históricas del paisajismo pictórico". Traducción de la autora.

438 Lefebvre, 1991: 38. "Como percibido, la práctica espacial; como concebido, la representación del espacio y como vivido, espacio de representación". Traducción de la autora.

${ }^{439}$ Mitch Rose Gathering 'Dreams of Presence': A Project of the Cultural Landscape. Reproducido en Davies, 2012: 3-4. "Como consecuencia de las distintas prácticas que envuelven e intervienen en la multiplicidad de formas con que el paisaje se manifiesta". Traducción de la autora.

${ }^{440}$ Richardson, 2012: 56.

${ }^{441}$ D. W. Meinig (ed) (1979). The Interpretation of Ordinary Landcape, 153." Durante más de 25 años he tratado de entender y explicar aquel aspecto del entorno que llamo paisaje. He escrito sobre ello, he divulgado sobre ello, he viajado para encontrarlo, y sin embargo, debo admitir que el concepto continua eludiéndome. Tal vez una razón sea que insisto en
} 
J. B. Jackson en The Order of Landscape reafirma la complejidad del paisaje a la que cabe sumar una naturaleza cambiante dependiendo de los contextos en que se desarrolle. En esta línea discurre el trabajo de Ann Davies en Spanish Spaces: Landscape, Space and Place in Contemporary Spanish Culture donde aborda la significación de los usos espaciales en los procesos de formación de lo que llama 'ente España'. Para lo cual, rastrea en los productos culturales las huellas "explicitly or implicitly, of Spain through their interaction with landscape, space and place ${ }^{442 " . ~ D e ~ h e c h o ~ D a v i e s ~}$ justifica la existencia de una multiplicidad de miradas que experiencian el paisaje por la imposibilidad de encontrar una forma perfecta de España. En definitiva, "Spain, then, is the sum of all these subjective viewpoints -and not only those I have considered here- but, because the process of forming subjectivity and subjective perspectives of Spain is never ending, Spain is always in the process of becoming ${ }^{443}$ ". Y del mismo modo lo es el imaginario rural.

Las tesis por la que se coincide en subrayar el carácter inconcluso de los procesos de construcción de los imaginarios colectivos en el marco del cine rural conduce a analizar los usos espaciales como "texts illustrating the beliefs of the people. The shaping of the landscape is seen as expressing social ideologies, that are then perpetuated and supported through the landscape ${ }^{444 "}$. En la misma línea la académica Doreen Massey defiende que el espacio es el producto de las relaciones espaciales, las cuales presuponen una coexistencia de los elementos operantes. $Y$ por su parte Karen Lury argumenta que "space and place are therefore useful as a way of understanding how film makes social relationships visible, or how they are

concebirlo no como una entidad escénica o ecológica y no como una entidad cultural y política, cambiante con el transcurso de la historia". Traducción de la autora.

${ }_{442}$ Davies, 2012: Conclusion. "Explícita o implícitamente de España a partir de su interacción con el paisaje, el espacio y el lugar". Traducción de la autora.

${ }^{443}$ Ibídem. "España, entonces, es la suma de todas los puntos de vista subjetivos [...] pero, debido al proceso de formación subjetiva y las perspectivas subjetivas de España esta nunca se concluye, España está siempre en el proceso de ser". Traducción de la autora.

${ }_{444}$ Crang, 1998: 27. "[...] textos que ilustran las creencias de las gentes. La forma del paisaje es vista como expresión de las ideologías sociales, que serán perpetuadas basándose en el paisaje". Traducción de la autora. 
articulated through the visual and aural capabilities of film and television ${ }^{445 " .}$ En palabras de Davies, "to consider the ways in which subjects express their personal desires [...] and how their interactions with the landscape call forth not only expressions of desire and of fears but how those desires and fears relate to where they are ${ }^{446 " . ~ A s i m i l a n d o ~ l a s ~ t e s i s ~ d e ~ D a v i e s ~ s e ~ c o n c l u y e ~ q u e ~}$ "[the rural] Spain traces itself across these subjectivities ${ }^{447 " . ~ P o r ~ l o ~ q u e ~ e l ~}$ análisis del cine rural español de los años cincuenta constata la multiplicidad de miradas que en suma constituyen el imaginario rural nacional previo a la modernización, impidiendo, por otra parte, abordar el cine rural en términos de género cinematográfico identificado en unos códigos formales y estéticos concretos.

La cuarta tesis se fundamenta en las interpretaciones del paisaje rural español en el proyecto de reconstrucción de un corpus referencial nacional. Nathan Richardson en Constructing Spain. The Re-Imagination of Space and Place in Fiction and Film, 1953-2003 insiste en las líneas de estudio de los autores anteriores coincidiendo con Davies en el termino 'entity' para referirse a España, lo que él llama "an enterprise that focussed attention on place and the spatial dynamics that governed $i^{448}$ ". Ante el panorama de devastación ocasionada por la Guerra Civil española "the Spainsh state and nation were undone" en términos materiales y morales debido a la orfandad ideológica y espiritual. Es entonces cuando "Franco's government overtly attempted to employ space as a key weapon in their blitzkrieg of Spanish identity ${ }^{449 ", . ~ E n ~}$ este punto cabe rescatar el valor simbólico atribuido a la región de Castilla cuyo abolengo histórico motivó a la Generación del 98 a buscar en ella la

\footnotetext{
${ }^{445}$ Lury; Massey (1999). "Making connections". Screen 40/3, 231. Reproducido en Davies, 20112: 2012. "El espacio y el lugar son, por lo tanto, útiles como medio para entender como las películas hacen visibles las relaciones sociales, o como interactúan a través de sus capacidades visuales y auditivas". Traducción de la autora.

${ }_{446}$ Davies, 2012: Conclusion. "Considerar los medios por los que los sujetos expresan sus deseos personales [...] y como sus interacciones con el paisaje requieren la presencia no solo de expresiones de deseo sino también de miedo, y como estos deseos y miedos los relacionan donde ellos están". Traducción de la autora.

${ }^{447}$ Ibídem." [La España rural] se traza a sí misma a partir de las [miradas] subjetivas". Traducción de la autora.

${ }^{448}$ Richardson, 2012: 4. "Un proyecto que centra su atención en las dinámicas que gobiernan el lugar y el espacio". Traducción de la autora.

449 Ibídem. "El gobierno de Franco abiertamente intentó emplear el espacio como arma en su cruzada para una identidad española". Traducción de la autora.
} 
intra-historia necesaria para una restauración de los valores nacionales, una práctica que el régimen franquista tomó puesto que consideró "the Castilian countryside [...] as the heart and soul of unified, homogenized Spain ${ }^{450 " . ~ S i n ~}$ embargo los postulados teóricos chocaron con la práctica real puesto que, como se ha analizado, no se produjo el rescate del campo español si no su marginación en aras de la modernización del país.

El campo español constituye un marco común de referencias estéticas, culturales e ideológicas. La asimilación de las tesis que conforman este marco teórico permite ahondar en la carga cultural y de valores implícita en las manifestaciones del paisaje y del territorio rural en el cine español de los años cincuenta. En primer lugar se destaca el proyecto de Cinco historias de España que, aun inconcluso, supone una mirada excepcional hacia el interior del país como territorio. $Y$ a continuación se presenta una propuesta de ordenación por los treinta y cuatro títulos restantes producidos entre 1950 y 1959 estructurada en base a los tres estadios identificados por Martin Lefebvre los cuales revelan unas fórmulas estéticas y narrativas concretas a partir de las cuales se conformó la mirada hacia el entorno rural español.

\subsection{Las Cinco historias de España de Muñoz Suay}

La labor comprometida de los alumnos del IIEC, tal y como se ha destacado, resulta interesante desde un punto de vista historiográfico, puesto que dentro del cine rural de este período solo existen dos proyectos realizados por alumnos salidos de sus aulas. El primero es Cinco historias de España gestado a tres bandas por Cesare Zavattini, Luis G Berlanga y Ricardo Muñoz Suay en 1954 pero que no llegaría al formato celuloide. Y el segundo fue La venganza de J. A. Bardem, 1957. En ambos casos se atiende al uso espacial en el estadio de territorio. Un hecho que remite al perfil ideológico de sus realizadores por cuanto ahondaban en la dimensión social

\footnotetext{
450 Ídem: 33. "El campo castellano [...] como el corazón y el alma de una España unificada y homogénea”. Traducción de la autora.
} 
del espacio en relación a la transformación política y en concreto a la evolución de la industria cinematográfica de esos años.

Las Conversaciones Cinematográficas de Salamanca concretaron las preocupaciones de diferentes sectores intelectuales por el futuro del sector de mediados de los años cincuenta. Una confluencia similar a la acaecida en tiempos del Desastre del 98 en que intelectuales y autores literarios aunaron esfuerzos con el fin de restituir el corpus referencial de la maltrecha España finisecular. En ambos momentos se apeló a la regeneración de unos modelos representacionales y de valores que participasen del desarrollo del cine y de la nación española, respectivamente.

El término 'regeneracionismo' hace referencia a aquellas posturas críticas tanto de la Generación del 98 como de los intelectuales de la década de los años 50 que cuestionaban las fórmulas de representación y el sistema hegemónico industrial. El historiador José Luis Castro de Paz atribuye la traslación del término regeneracionismo al ámbito cinematográfico a Román Gubern cuando en su ensayo La presencia de Bardem en los inicios de la obra de Berlanga, 1981, establecía analogías entre "la catástrofe políticosocial de la Guerra Civil y sus secuelas [y] la 'catástrofe colonial' que concienció a los intelectuales del $98^{451 "}$. Sendos episodios de resistencia ideológica y sentir crítico fueron gestados en condiciones adversas por intelectuales implicados en el progreso de la nación mediante "el culto a las raíces nacionales $452 "$. Si bien, como ya sucediese en la heterogeneidad ideológica de los asistentes al encuentro salmantino y que perseguían la

\footnotetext{
${ }^{451}$ En Pérez, 1981: 32-35.

${ }^{452}$ En detalle el texto dice así: "En aquellos años de severísima censura administrativa, el espíritu 'regeneracionista' del 98 fue recuperado por estas revistas como reacción tras la catástrofe político-social de la Guerra Civil y sus secuelas, parangonable a la 'catástrofe colonial' que concienció a los intelectuales del 98, muchos de ellos mal vistos o prohibidos en esos años triunfalistas del franquismo. Recordemos que la Generación del 98 estuvo formada por intelectuales de origen burgués que reaccionaron contra los valores vigentes de la burguesía de su época y, con un 'me duele España' como divisa, intentaron un compromiso entre el progresismo decimonónico y el culto a las propias raíces nacionales, buscando las soluciones a los problemas colectivos desde el interior de la realidad española. [...] La difusa ambigüedad de estas propuestas hizo que pudieran ser compartidas por un espectro tan amplio que abarcaba desde los falangistas de izquierda, a los católicos y a los comunistas, que las invocaron de un modo más o menos ingenuo, auténtico o táctico, según los casos".
} 
revitalización de la cinematografía nacional a través de la revisitación de la tradición cultural unió a intelectuales de perfil falangista como Laín Entralgo que habían asimilado el ideario de Joaquín Costa, el primer Maeztu, Azorín, Unamuno u Ortega con Juan Antonio Bardem y Ricardo Muñoz Suay al frente de la facción cinematográfica de los intelectuales comunistas. Una circunstancia que desmonta la generalizada práctica historiográfica de identificar el cine regeneracionista con un cine contestatario secundado, básicamente, por los militantes de izquierdas.

En este punto los postulados de Muñoz Suay ya descritos en el contexto de del encuentro salmantino se desarrollan en detalle por cuanto actualizan los razonamientos de la Generación del 98 en relación a la experiencia del entorno rural español. Esteve Riambau conviene que la estrategia de Muñoz Suay se desarrolló en tres frentes, uno reflexivo materializado en la revista Objetivo, "en defensa de un cine realista opuesto a las tendencias oficiales". Un segundo de admiración por Cesare Zavattini y un tercero, las Conversaciones de Salamanca, "foro de debate con el que el PCE veía colmadas sus expectativas de aglutinar a sectores intelectuales de distinto matiz ideológico pero simultáneamente preocupados por el devenir del cine español ${ }^{453 " . ~ M u n ̃ o z ~ S u a y ~ c u l t i v o ́ ~ s u ~ p r o p u e s t a ~ d e ~ r e h a b i l i t a c i o ́ n ~ d e l ~ c i n e ~}$ español entre estos tres frentes asentados sobre el factor realismo que precisaba de la revisitación de los referentes nacionales pretéritos:

"España es virgen en todos los sentidos. Su pueblo, sus gentes, esperan con esperanza el día en que su vida, trágica o simple, colectiva o individual, pueda expresarse realísticamente en el cine. El pasado cultural e intelectual de España es un pasado realista. Su teatro, su novela, su poesía, su pintura y su escultura han entregado al mundo obras llenas de humanidad y de realismo. Lope de Vega, Cervantes, Alberti, Goya y Berruguete son algunos ejemplos. Si tenemos presente de un lado el sentimiento realista del hombre español y del otro una situación virgen, que contiene una vida llena de realidad podemos estar seguros de que el cine español puede y debe ser realista ${ }^{454 " .}$

\footnotetext{
${ }^{453}$ Riambau, 2007: 227.

${ }^{454}$ Publicado en el primer Boletín del Neorrealismo dirigido por Guido Aristarco y consultado a partir de la reproducción en Ídem: 232.
} 
En una misiva fechada el 17 de enero de 1954 Muñoz Suay se dirigía a Zavattini agradeciéndole la predisposición a colaborar juntos:

"Mi mayor ilusión sería que Berlanga y yo pudiéramos firmar un escenario con usted. Sería, además, la ayuda más grande que usted podría hacer para un resurgir de nuestro cinema. Sería darnos nuevas armas para combatir, desde nuestro "caballo de Troya", por la consecución de un cinema digno, realista, verídico ${ }^{455 " . ~}$

La colaboración se concretó en los proyectos Festival de Cine y Cinco historias de España, este último como reacción a la inviabilidad del primero pero que tampoco llegaría a materializarse. Zavattini que ya tenía en mente la idea de una Italia mía y anteriormente un México mío y Cuba mía vio la oportunidad de realizar una especie de España mía, que finalmente se llamó Cinco historias de España ${ }^{456}$. El proyecto perseguía "la idea de escribir unas historias que transcurriesen en España, pero que no fuesen inventadas de antemano. Queríamos escribirlas después de haberlas visto y oído ${ }^{457 "}$. Para ello debían recorrer la geografía española, como hiciesen Azorín o de Unamuno en su momento, "en busca de una verdad española" que fundamentase "siete u ocho historias independientes, interpretadas por las gentes que nos encontremos en los pueblos, en las carreteras, en las ciudades, en el mar, en la montaña ${ }^{458 ”, ~ d e c l a r a b a ~ M u n ̃ o z ~ S u a y . ~ E n t r e ~ j u l i o ~ y ~}$ agosto de 1954 Zavattini, Berlanga, Muñoz Suay y Francisco Canet recorrieron Tendilla (Guadalajara), Cañeta y Villanueva de la Jara (Cuenca), Los Monegros (Zaragoza y Huesca)... Con escalas en Cuenca, Teruel, Barcelona, Ávila, Zamora, Lugo, Vigo, Salamanca, Valladolid, Madrid, Córdoba, Écija, Albarracín, Las Hurdes hasta volver a Madrid.

En su diario personal con fecha 4 de agosto de 1954 Muñoz Suay declaraba estar convencido que "viajar por España con Zavattini equivale, en muchas ocasiones, a encontrar una España desconocida por nosotros

\footnotetext{
${ }^{455}$ Reproducido en Ídem, 234.

${ }^{456}$ Publicadas íntegramente por la Filmoteca de la Generalitat Valenciana en 1991. Y fragmentariamente en el número de Cinema Universitario de marzo de 1955.

457 Zavattini, Berlanga, Muñoz Suay, 1991: introducción.

${ }^{458}$ En una misiva a Font fechada el 30 de julio de 1954. Ibídem.
} 
mismos. Es ir levantando actas notariales en las que quedan reflejadas esas vidas de nuestro pueblo que tienen suficientes valores como para ser reconstruidas cinematográficamente". Un ejercicio de inmersión en la realidad circundante que buscaba los testimonios y la convivencia "con los humildes y ricos, tocando nosotros mismos la realidad, hicimos Neorrealismo ${ }^{459 ",}$ aseguraba Muñoz Suay.

Por un lado la presencia de Zavattini explica en los siguientes términos los postulados desde los que se entendía la experiencia de realidad del grupo. En palabras del propio Zavattini:

"El deseo de convivencia [...] puede nacer de experiencias de tipo ancestral, pero a nosotros -argumentistas, guionistas, realizadores- lo que nos debe interesar es el establecimiento de sólidos vínculos con los otros hombres y con la realidad... Pocos tienen paciencia para observar y escuchar. $\mathrm{Y}$, sin embargo, es suficiente un gesto o una palabra para transformar un vínculo ${ }^{460 "}$.

Y por otro lado este proyecto sintetizaba el esfuerzo por mirar más allá de donde todos miraban cuando se trataba de trasladar la ruralidad al formato cinematográfico. De hecho los precedentes a esa mirada vivida del entorno rural son escasos. La aldea maldita de Florián Rey, 1930, Tierra sin pan de Luis Buñuel, 1932 o Sierra de Teruel de André Malraux, 1939. Si bien, salvando las distancias entre las particularidades constitutivas de estos tres títulos, además del perfil ideológico de sus realizadores en relación al contexto político de su tiempo, desde un punto de vista historiográfico estas películas constituyen la contra-mirada a una realidad rural en plena fagocitación de la vertiente folclórico-popular proyectada a partir de la preconcepción de su imaginario.

Del periplo del grupo surgieron siete historias de las que se seleccionaron cinco. El pastor tiene acontece en La Mancha, Emigrantes en un lugar indeterminado de Galicia, La capea durante las fiestas populares de un

\footnotetext{
459 Ibídem.

460 "Un material neorrealista". En Cinema Universitario. Núm.1, marzo de 1955.
} 
pequeño pueblo andaluz, Soldado y criada en Barcelona y Las Hurdes. En todas ellas el, los o la familia obrera o campesina toman el protagonismo y las hazañas propias de su condición social se convierten en el tema de las narraciones. Como sentencia el primer párrafo del libreto:

"Esta es la tierra donde he nacido, España. Ved, es como una gran piel de toro extendida sobre el agua, por una parte unida o separada por esos montes famosos de Europa, los Pirineos. Está habitada por veintiocho millones de criaturas, ricos y pobres, buenos y malos, pero esta vez yo quiero contaros sólo las historias de la gente más humilde de mi país, campesinos, obreros, pastores, emigrantes. Son historias que no he inventado ni yo ni mis amigos, son historias que la realidad misma nos ha sugerido".

Además, el desarrollo de su periplo sirve como vehículo para la descripción del paisaje en que tiene lugar por ejemplo El pastor:

"La primera, se desarrolla aquí en la Mancha, la región más infinita de España, donde la vista no logra casi nunca alcanzar el horizonte. Este es un año lleno de polvo y de viento; basta el paso al trote de un asno para levantar una nube de polvo. Es que ha caído poca agua del cielo y los hombres y las bestias están unidos en el deseo del agua, en la espera del agua. Adonde hay un charco, llegan desde lejos los bueyes, los caballos, los asnos, las cabras, las ovejas, a saciar un poco su sed. Las grandes presas permanecen allí, quietas y secas, como fuera del tiempo".

Emigrantes se desarrolla:

"En Galicia. Esa tierra que, como dijo Rosalía de Castro, está llena de "prados, ríos, arboledas". Aquí suena la gaita y se baila la muñeira. EI Atlántico bate sus costas con grandes ola y en sus montañas hay siempre inmensas nubes. La tierra está dividida en pequeñas parcela, y el gallego defiende su pequeña propiedad circundándola de piedras ${ }^{461 "}$."

O Las Hurdes:

"Ésta es Extremadura, la carretera que va hacia las ciudades de Cáceres y luego a Plasencia. Vemos campos llenos de bellotas, que

${ }^{461}$ Zavattini, et alii, 1991: 18. 
sirven para comida de los cerdos. Encontramos, por cierto, campesinos con innumerables grupos de puercos; vemos también rebaños de ovejas, más numerosos que en las demás regiones de España; pastos cerrados por muros, desde los cuales despuntan las cabezas de los caballos o de las mulas, y de vez en cuando, visiones fantásticas de gigantes peñas en medio del campo".

Todas estas narraciones son el resultado de la traslación escrita de la experiencia del grupo de autores en los diferentes lugares que visitaron y en que asumen la condición espectatorial, "nosotros vemos esto recorriendo el camino en dos grandes "jeeps ${ }^{462}$ "”, escribe Muñoz Suay. Una proximidad física y temporal que, a su vez, enfatiza la veracidad de los caracteres del paisaje descrito.

El objetivo de los textos recopilados por Muñoz Suay fue servir como actas del paisaje español pero también de sus gentes y los problemas derivados de su condición social lo que, en la línea de pensamiento de Henri Lefebvre, permite hablar del entorno rural en términos de territorio vivido. Por ejemplo el pastor protagonista del primer relato debe hacer frente a la sequia común de la Mancha, al acecho de los lobos y los problemas de salud que le acarrea su profesión, en suma, a los avatares propios de su relación con el entorno rural.

"[Él un] viejo pastor [que] tiene cerca de setenta años y viste como todos los pastores de la Mancha. Camina con fatiga sujetándose con la mano su sombrero para que no vuele, gritando misteriosas palabras a las ovejas que se paran a un lado del camino. [...] He aquí la cara del pastor, quemada, rugosa, barbuda y con dos ojos rojos por el polvo que, cansadamente, miran a la tierra ${ }^{463 "}$.

Por su parte la familia de Emigrantes se ve obligada a mandar a su hija a trabajar a Uruguay. El fenómeno migratorio protagonizado por el estamento obrero evidencia las dificultades de supervivencia de las familias campesinas que, como la del relato, debe malvender su burro para comprar una maquina de coser que, presumiblemente, será la herramienta de trabajo de la hija en su destino.

\footnotetext{
462 Ídem: 40.

463 Ídem: 13.
} 
El relato Las Hurdes ahonda en la mirada sobre la miseria de la España negra. A Nuñomoral llega un grupo de jóvenes voluntarios decididos a regalar su tiempo y trabajo a su comunidad aldeana con el objetivo de mejorar sus condiciones de vida. Un proyecto que, sin referencias explícitas, recuerda a las iniciativas de aquellos años del Padre Llanos a través del Servicio Universitario del Trabajo y del Trabajo Dominical por el que se ofrecían experiencias de auxilio en las zonas más humildes del extrarradio urbano y del entorno rural. En el relato el grupo de Muñoz Suay es testigo del encuentro entre la comitiva de voluntarios y los vecinos que describe como gentes desconfiadas, ignorantes, lentas y primitivas. Condiciones que reúne el personaje de Jesusín, un niño de la aldea que no responde a las interacciones de uno de los jóvenes, ejemplificando el atraso social de estas comunidades rurales.

En conclusión el proyecto Cinco historias de España de Zavattini, Berlanga y Muñoz Suay representa la confluencia de los postulados del llamado regeneracionismos cinematográfico asentados en las fórmulas del realismo de inspiración italiana con la reformulación en clave identitaria de la tradición paisajística de la Generación del 98. La importancia de este proyecto en el contexto de este trabajo reside en la mirada del entorno rural en la conjunción de que hablaba Martin Lefebvre entre paisaje y territorio, situando el foco de interés en los conflictos reales derivados de la condición campesina. Desafortunadamente el proyectó no adoptó forma cinematográfica "entre los compromisos de Zavattini con su obra global y las ideas de Luis sobre un cine diverso al que nos habíamos comprometido, nos llevó a todos a un callejón sin salida ${ }^{464 ",}$ declaró Muñoz Suay. Por lo que resulta imposible imaginar el impacto, al menos desde un punto historiográfico, que la puesta en imágenes de la experiencia del grupo de autores hubiera tenido en el imaginario rural español.

${ }^{464}$ Reproducido en Riambau, 2007: 243. 


\subsection{Las fórmulas del cine rural español}

El cine rural no constituye un género cinematográfico propiamente dicho, por lo que el conjunto de los treinta y cuatro títulos que componen la producción de cine rural de la década de los años cincuenta se ordena en función a los usos espaciales definidos por Martin Lefebvre de setting, landscape o territory. Estos tres estadios son entendidos como "realms of agreement ${ }^{465 "}$ en relaciones a sus coincidencias temáticas más elementales. A grandes rasgos, se trata de un conjunto de películas que se sitúan en los estadios de una ruralidad percibida y concebida, en el sentido empleado por Henri Lefebvre. Que bien constata los regionalismos a partir de la fórmula del folklore o las derivas de la comedia y el musical o perpetua el género del drama rural siguiendo la tradición de acudir a la meseta castellana. Con la excepción de La venganza, película de inflexión junto al proyecto de Cinco historias de España que se desarrolla desde una mirada vivida del campo español adentrándose en la dimensión social del territorio.

Sobre la vía folklórica-populista del cine Castro de Paz destaca "las vertientes del melodrama campesino/drama rural de tintes regionalistas, sainete fílmico [...] cuyos referentes parten de espectáculos populares de 'revista' todas ellas de orígenes que hunden sus raíces en el teatro popular español" y que, a diferencia del sesgo social del cine republicano, dará paso a "lo religioso como preeminente eje conductor de las ficciones, construidas para cantar [...] las alabanzas de los imperecederos y recios valores $y$ tradiciones regionales de los pueblos de la patria ${ }^{466 " . ~ S e ~ t r a t a ~ d e ~ u n ~ c i n e ~ q u e ~}$ ahonda en la tipificación de los arquetipos de la cantaora gitana y el bandido, localizado en cuevas y cortijos andaluces en un tiempo pretérito, elementos todos ellos que apelan directamente a la España mítica de la literatura de viajes.

El entorno rural funciona como escenario para el desarrollo de la trama de Carne de horca, 1953 sobre la leyenda de Juan Lucero, un célebre bandolero

\footnotetext{
${ }^{465}$ Harper; Reyner, 2010: 13.

${ }^{466}$ Poyato (Coord.), 2007: 75-98.
} 
de Sierra Morena. Ladislao Vadja aborda esta figura del imaginario popular a partir de la narración de La venganza de Juan Pablo, señorito de la oligarquía rural andaluza cuya adicción al juego lo lleva a urdir un plan para saldar sus deudas uniéndose a la partida de Juan Lucero. Una ficción de acción "a favor de la formulación de un cine popular [...] que sin dejar de ser autóctono [se aprovechaba] de las enseñanzas que podían extraerse del western americano ${ }^{467}$." En Carne de horca la particularidad del enclave natural es abordada desde la doble vertiente del mito -el bandolerismo decimonónicoen estrecho vínculo con la realidad social, esta es la estratificación de la comunidad aldeana. La conjunción de estos dos referentes resultó en que:

"Los bandoleros no son románticos dados al aventurismo justiciero sino la más vil y explícita prolongación de la actitud de un segmento de la clase dominante; ésta, por su parte, no es homogénea ni en composición ni en intereses [...] y los campesinos, no son sólo víctimas pusilánimes de toda la situación, sino una fuerza capaz de reaccionar si las condiciones objetivas lo permiten ${ }^{468 " .}$

En conclusión el tratamiento espacial y arquetípico de Carne de horca contribuye a la vertiente cinematográfica que nutrió la iconografía popular española en clave mitológica obviando los problemas reales del campo español de 1950.

Generalmente, las películas protagonizadas por el arquetipo del bandolero repeten las fórmulas de Carne de horca sin llegar a constituir un género como fuese el western americano. Tal fue el caso de Amanecer en Puerta Oscura de José María Forqué, 1957, en que el desarrollo argumental consiste en el trayecto de huida de dos fugitivos acompañados del bandolero Juan Cuenca por la sierra andaluza del siglo XIX. La película de Forqué resulta interesante porque introduce una secuencia de revuelta laboral, tal y como se analizará posteriormente. La sierra andaluza se convierte en el espacio simbólico para este conjunto de películas donde se desarrollan argumentos en tiempo

\footnotetext{
${ }_{468}^{467}$ Pérez (Coord.), 1997: 340-342.

468 Ibídem.
} 
pretérito aludiendo a una España mágica, fuera de la ley, poblada de seres salvajes fuertemente romantizados.

Gran parte del metraje de La montaña sin ley de Miguel Lluch, 1953, también discurre en la sierra andaluza. Destacan las secuencias inicial y de desenlace de persecución a caballo entre bandoleros construidas sobre un trabajo de montaje que da cuenta de la función del espacio rural en el cine de bandoleros. Lluch incurre en la tipificación de sus personajes para construir la línea dramática sustentada en el triángulo amoroso formado por el forastero, la gitana María y la mujer de Don Rafael. El arquetipo de la gitana es otro de los referentes populares del imaginario rural nacional, representado en su faceta usurera al adoptar la perspectiva de los oligarcas rurales. Además tiene lugar un episodio de demostración de virilidad ante el astado. Junto a los duelos a navaja son estas secuencias son recurrentes en la representación de los modos de vida rurales desde miradas concebidas en lo exótico.

También es frecuente el recurso a la copla como medio para introducir fábulas pretéritas que condicionarán el presente narrativo de las comunidades protagonistas, como sucede en María Morena, 1951. El drama de José María Forqué está protagonizado por una joven gitana que resolverá la injusticia acaecida a El Sevillano, condenado a muerte por su condición de bandolero. El trayecto narrativo del filme se sustenta en la importancia del romance como medio para transmitir la historia popular de unas comunidades regidas por las creencias y las supersticiones surgidas, en este caso, del crimen de la Casa Negra. Finalmente, el arquetipo femenino, construido en base a una mujer joven y gitana, es interpretado por la coplista Paquita Rico poseedora de la gracia andaluza como también sucede con el personaje de Lola Flores en Estrella de Sierra Morena de Ricardo Torrado, 1952. Esta película cuenta la historia de una huérfana criada por un grupo de bandoleros. Ya de adulta la protagonista deberá descubrir quien es su verdadero padre a la vez que defender los intereses de su familia adoptiva, obstáculos que resolverá, como la protagonista de María Morena, recurriendo a su gracia verbal y sus habilidades para el baile y el cante. Unas aptitudes 
explotadas por Torrado a lo largo del filme en diferentes números musicales y otras escenas basadas en el gag verbal sobre las carencias intelectuales del estamento que representa la protagonista.

La tercera coplista de los años cincuenta que interpretó el arquetipo de la gitana fue Carmen Sevilla en sus personajes en La pícara molinera de León Klimovsky, 1955, y Un caballero andaluz de Luis Lucía, 1954. Sevilla constituye el eje sobre el que se desarrollan sendas narraciones, así como el principal reclamo promocional. Klimovsky se sitúa en 1787 para versionar el romance popular del molinero de Arcos de la Frontera en que Lucía, la molinera, debe zafarse del acecho -en clave sexual- de las autoridades locales. En tono humorístico se presenta esta comunidad rural dividida en dos estamentos sociales en que las clases dominantes abusan de los trabajadores, constituyendo el personaje de la molinera el paradigma de la desprotección del estamento campesino. El espacio rural funciona como la fuente de su sustento pero a la vez la aísla socialmente fomentando la imagen de la mujer rural indómita, temida a la vez que deseada, como es el caso, por las oligarquías locales. El tratamiento cinematográfico de la mujer rural será analizado en el capítulo posterior.

Por su parte Luis Lucía explota las dotes artísticas de Carmen Sevilla en Un caballero andaluz donde da vida a Colorín, una gitana invidente al cargo de diez hermanos. La narración tiene como escenarios las cuevas que habitan los gitanos y el cortijo del señorito Don Juan Manuel dedicado a la cría de toros. El realizador empareja a la carismática gitana con el señorito andaluz valedor de las virtudes del género masculino, y por extensión del ciudadano español. Ambos protagonizan una historia de amor cuyo tratamiento en clave cómica pondrá de manifiesto la idiosincrasia social del entorno rural andaluz.

Este conjunto de películas ejemplifican la vertiente narrativa por la que el entorno rural funciona como espacio pretérito contenedor de unos valores patriarcales rígidos que impiden la evolución a paisaje o territorio social 
perpetuando, finalmente, las fórmulas del folclore asociadas en décadas anteriores a la españolada.

El escenario del cortijo andaluz es otro de los enclaves recurrentes en el cine rural. Eusebio Fernández Ardavín sitúa Vértigo. Casta Andaluza, 1950, en una finca sevillana, donde tres mujeres -dos de la misma familia acomodada y una humilde coplista- se disputan el amor del protagonista. Se trata de un drama pasional donde el entorno rural funciona como metáfora del entramado sentimental descrito, a su vez opuesto al entorno urbano. Un ejemplo lo constituye la escena en que el matrimonio protagonista visita Sevilla pero la extrañeza que les despierta la ciudad confirma su pertenencia al entorno rural. Esta oposición, aunque breve en el metraje, ejemplifica la práctica de dotar de valores negativos los núcleos urbanos como lugares de libertinaje y disgregación de los valores nacionales en beneficio de la pureza y la bondad de los núcleos rurales. Las consecuencias de disyunción campociudad también fundamentan la trama de Surcos de Antonio Nieves Conde, 1951, sobre el choque cultural que sufre la familia campesina migrada a los suburbios de Madrid.

La gata de Rafael Torrecillas y Margarita Aleixandre, 1956, también discurre en un cortijo onubense dedicado a la cría de astado. La película aborda la cuestión rural despojado del conjunto de arquetipos hasta ahora mencionados para ahondar en un corpus referencial regido por el carácter bravo de los animales. El argumento de La gata lo constituye:

"[una historia de] deseos, amoríos, sospechas, traiciones, desamores y muerte ${ }^{469 "}$ introducida en los títulos de crédito por una copla y narrada en forma de flashback. El escenario del cortijo funciona como manantial de las pasiones sexuales por lo que el carácter de los protagonistas se asemeja al perfil de los animales. Juan, "prototipo del marginal y furtivo, macho mujeriego y exhibicionista, héroe frío y solitario" se asocia al toro, mientras que María como una gata es "arisca o cariñosa [...] suave y zalamera $^{470 " .}$

\footnotetext{
${ }_{470}^{469}$ Gabriel Martín en Pérez (Coord.) 1995: 386-388.

470 lbídem.
} 
Este tratamiento del espacio rural en relación a sus habitantes discurre en la vertiente metafísica desarrollada por Manuel Mur Oti como se analizará posteriormente.

Existen otros dos arquetipos recurrentes en las ficciones rurales. El primero es el párroco de pequeñas comunidades donde deberá ejercer de mediador entre los vecinos. En las películas La guerra de Dios de Rafael Gil, 1953, y El padre Pitillo de Juan de Orduña, 1954, este arquetipo logra el protagonismo absoluto erigiéndose en figura de referencia moral. En el filme de Gil el párroco se encuentra ante un conflicto laboral entre los trabajadores y el patrón de una mina. Atendiendo al contexto de acercamiento del régimen franquista a la Iglesia católica en su estrategia de supervivencia, Pérez Gómez interpreta el personaje como "trasunto de un joven franquista modélico". Valga como apunte que el filme fue premiado por el Sindicato Nacional de Espectáculo por la "exaltación de los valores espirituales y sociales del régimen ${ }^{471 "}$. Es más, el peso del personaje en la trama relega a un segundo plano la línea del conflicto social, analizada posteriormente.

Desde una perspectiva cómica Juan de Orduña aborda el arquetipo del cura mediador de El padre Pitillo. Una representación de tono amable de la comunidad rural que da cuenta de los tipos y modos de vida de la misma sin ahondar en cuestiones sociales críticas como fuese la falta de comida, el atraso tecnológico o cuestiones de género.

En definitiva, el uso del espacio rural en estas ficciones ahonda en el estadio de setting, dominado por el mensaje evangelizador transmitido a partir de la figura del religioso en el contexto de alianza con la Santa Sede.

El segundo arquetipo es el forastero. El proceso de descubrimiento del extranjero funciona formalmente como mecanismo mediante el que revelar el estado de la comunidad rural como sucede en Puebla de las mujeres, 1952. La comedia de Antonio del Amo que versiona la obra de los hermanos

${ }^{471}$ Pérez Gómez en Pérez (Coord.), 1997: 331-333. 
Álvarez Quintero, 1912. La coplista Marujita Díaz interpreta a Juanita la Rosa una de las muchachas de la localidad que intentará, con sus habilidades para el cante y el baile, enamorar al forastero. En la línea de las películas folklórico-populistas, el arquetipo femenino constituye el eje central sobre el que se representa la comunidad rural. En otro orden de cosas, en dos escenas de Puebla de las mujeres el aburrimiento de los pueblos ${ }^{472}$ es un tema recurrente de conversación. Una cuestión que revela una mirada condescendiente hacia los habitantes rurales justificada por la falta de estímulos intelectuales como le sucede al antagonista, Pablo Lobo ${ }^{473}$.

En un segundo estadio del uso del espacio rural se han identificado una serie de películas que, dentro de la fórmula del drama, abordaron distintos avatares derivados de la cuestión rural, como es la escasez del agua. Desde una perspectiva historiográfica la presencia de esta cuestión en las tramas argumentales revela un interés más cercano a la casuística de la vida del campo español. En unos años en que el régimen franquista admitía los graves problemas de sequía y empobrecimiento de las zonas rurales haciendo del Plan Badajoz uno de sus grandes valedores. Sin embargo, la traslación cinematográfica de esta problemática no supone una mirada crítica del espacio rural aunque si se distancia del imaginario rural construido por los títulos hasta ahora mencionados que tomaron el regionalismo andaluz como paradigma de la ruralidad española.

La falta de agua es el núcleo argumental de Agua sangrienta de Ricardo Torres, 1954. El drama está protagonizado por una familia campesina que se esfuerza en trabajar unas tierras áridas a la espera de construir un nuevo pozo de agua. Torrado establece el grado de acercamiento a los tipos campesinos a partir de la voz en over inicial que declara:

\footnotetext{
${ }^{472}$ En una escena el cura pregunta al protagonista, Adolfo:

- ¿Qué te ha parecido el pueblo, aburridito, no?

- Como todos. Tengo la sensación de que están dormidos.
}

En otra escena Concha, del grupo de las mujeres, exclama: "En los pueblos nos aburrimos tanto que lo que teníamos que decir mañana lo decimos hoy, y lo que teníamos que decir hoy lo dijimos ayer y así sucesivamente".

${ }^{473}$ Uno de los chistes del filme tiene como protagonista a Pablo Lobo, el antiguo pretendiente de Juanita, que confunde las palabras sinónimo con anónimo al referirse a una nota que ha recibido. 
"Hablar del campo es hablar de las pericias que viven en él labradores y obreros curtidos por el sol, el aire y el frío sufren la dura prueba de su trabajo. [...] Siguen sin cobardía. [...] Volviendo el agua [...]. Solo en las tierras sedientas adquiere esta palabra su valor".

La narración se acompaña de una consecución de planos de las diferentes tareas del campo. El trayecto narrativo de Agua sangrienta discurre sobre diferentes episodios de sumisión de la familia campesina a los caciques locales empeñados en boicotear las obras del nuevo pozo. Una serie de injusticias que se resuelven con el préstamo económico del médico arquetipo mediador entre estamentos y portador de los buenos valores- y el descubrimiento del boicot por parte de los antagonistas. Además, ahondando en el imaginario rural, Torrado incluye en la representación de la comunidad rural una historia de amor interclasista, un episodio festivo sobre una corrida de toros y el arquetipo del torero en su faceta risueña.

Sin embargo, el problema del agua ya constituyó la excusa argumental de Tierra sedienta de Rafael Gil, 1945, la adaptación de la obra homónima de José Fernández Gómez sobre la construcción de un pantano en una zona rural. Se trata de una temática coetánea ${ }^{474}$ a la producción del filme en que las políticas económicas del gobierno franquista iniciaban el proyecto de construcción de carreteras, pantanos y vías de tren invadiendo el campo español, el cual experimentaba un proceso de transformación y desarrollo agrario sustituyendo las formas de producción tradicionales por otras mecanizadas $^{475}$. El argumento de Tierra sedienta parte del entramado sentimental de los protagonistas para acabar representando el choque entre tradición y modernidad, ilustrado a partir de la disyuntiva entre aquellos vecinos que contemplan la destrucción de sus campos y aquellos que ven en la nueva infraestructura la única vía para sobrevivir en el campo español.

La imposición de las ideas capitalistas al estamento campesino también constituye la base del conflicto dramático de Las aguas bajan negras de José

\footnotetext{
${ }^{474}$ La voluntad del filme por ubicarse en el contexto contemporáneo de 1945 queda manifiesta con el personaje de Andrés: el protagonista vuelve al pueblo tras la Guerra Civil española.

${ }^{475}$ Alonso et alii, 1991: 42.
} 
Luis Sáenz de Heredia, 1948, inspirado en la novela La aldea perdida de Armando Palacio Valdés. En tiempos de las guerras carlistas una comunidad rural asturiana se aferra a la tierra ante la llegada de empresarios extranjeros decididos a transformar su hogar y fuente de sustento en minas de carbón. Las diferentes subtramas del filme darán cuenta de una comunidad rural compuesta por todos sus tipos agrupados por el código de solidaridad frente al agente extranjero. El trayecto narrativo concluye en el momento en que los habitantes de la ficticia Rubiercos consiguen establecer su propia definición de progreso sin renunciar a la identidad que les confiere su vínculo con la tierra que habitan. La película de Sáenz de Heredia es interesante teniendo en cuenta la trayectoria afín a los postulados del régimen franquista. Por un lado el argumento se planteó desde la oposición al cambio por parte de una comunidad rural atada a su tierra. Pero al mismo tiempo aborda el problema de la sequía trasladado a un tiempo pretérito, respondiendo a la estrategia de los dictámenes censores preocupados por evitar cualquier identificación de los avatares argumentales con los problemas reales de la España premoderna.

Llegaron siete muchachas de Domingo Villadomat, 1954, también aborda los problemas de afección de las aguas en una comunidad rural. A la ficticia Villalvilla llega un grupo de jóvenes especialistas para desarrollar tareas sociales. Aunque la diégesis argumental no identifica el proyecto del grupo este se vincula con las tareas de la Sección Femenina, la vertiente asistencial del aparato franquista. Entre las mujeres hay una médico y una profesora que harán frente a la intransigencia de los dirigentes locales con el objetivo de salvar a una comunidad rural desvalida e iletrada. La representación de la comunidad rural precisamente desde esta faceta enaltece la función del grupo de mujeres, presentado como la herramienta del exterior que armará de valor al estamento campesino para hacer frente a los poderes corruptos locales. Villadomat ofrece una mirada del entorno rural en su faceta dramática al escoger a un pueblo abandonado del progreso y por ello desamparado socialmente. Si bien, el tono cómico sumado a las subtramas sentimentales resta peso a la parte dramática de dicha situación con referencias a la realidad social del momento. 
Del conjunto de películas que abordaron la cuestión rural desde los preceptos de la comedia Bienvenido Mr. Marshall de Luis García Berlanga, 1952, constituye el paradigma del tratamiento de la realidad del campo español en los límites de lo decible en el contexto de la dictadura franquista. En el castellano Villar del Río los vecinos se afanan por recrear un pueblo andaluz con el objetivo de agradar a los enviados americanos en el contexto real del European Recovery Program. La elección de esta transformación identitaria es sintomática de la tradición por vincular el regionalismo andaluz con la identidad nacional. Una hazaña que pone de manifiesto las carencias de esta comunidad metonimia de una país mayoritariamente rural y por ello ligado al transcurso de los ciclos agrarios, como exclama a modo de corolario la voz en off: "Y algo nuevo, más importante, sucede a la mañana siguiente, llueve. Con esa lluvia los campos mejorarán, la cosecha será mejor. Y mientras sale el sol el trabajo comienza de nuevo. Porque es bueno tener ilusiones, pero es mejor confiar en el propio esfuerzo de cada uno".

El tratamiento espacial de Bienvenido Mr. Marshall remite a los estudios sobre el valor simbólico del espacio en la definición de la identidad nacional. Una cuestión teorizada por Richardson a partir de los postulados de Henri Lefebvre, "the focus of the film shifts from questions of mere rebuilding (perceiving and conceiving space) to the possibilities of reimagining a nation

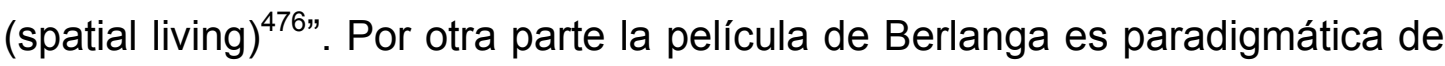
las teorías de Benedict Anderson sobre las comunidades imaginadas y justo esta se sitúa en la Castilla rural, región cuyo valor simbólico ha sido una constante en el devenir de la construcción de la identidad nacional, como se ha argumentado. No obstante, y como advierte Richardson, "the back-andforth between village and film set, between citizen and spectatorship, remains unresolved". Pero debido a que esta cuestión excede los límites de este apartado, se concluye que el espacio rural de Bienvenido Mr. Marshall representa la alianza entre España y Estados Unidos la cual inspiraría no

\footnotetext{
${ }^{476}$ Richardson, 2012: 37. "La atención de la película se desplaza desde cuestiones meramente de reconstrucción (espacio concebido y preconcebido) hasta la posibilidad de reimaginar una nación (espacio vivido)". Traducción de la autora.
} 
solo la reimaginación de la comunidad rural si no también "drastically reshape the space that underlies it ${ }^{477 "}$.

De nuevo una comunidad rural adopta otra identidad para conseguir el dinero que mejorará su calidad de vida en Un indiano en Moratilla de León Klimovsky, 1957. Aunque en este caso no existe un trasfondo crítico, ni hace referencia al contexto político del momento. El engaño consiste en crear una familia al indiano que regresa a su pueblo natal en busca de parientes. El trayecto narrativo discurre en torno a una serie de giros cómicos surgidos de las incongruencias de los impostores hasta que, finalmente, se descubre la verdad. Como también sucediese en Bienvenido Mr. Marshall los vecinos de Moratilla sueñan de que modo la ayuda económica del forastero mejorará sus vidas, concluyendo en ambos casos en una mirada patética del campesinado español sujeto, inextricablemente, a los condicionantes del espacio que habita.

En ¡Aquí hay petróleo!, Rafael J. Salvia, 1955, tal y como sucediese en Bienvenido Mr. Marshall, la visita de un grupo de americanos despierta de la letargia a los vecinos de la ficticia Castilviejo. La llegada de una expedición en busca de yacimientos petrolíferos transforma las costumbres y modos de vida de esta comunidad que intentará dirigir la tecnificación de sus propias tierras. El choque entre los extranjeros y la comunidad aldeana se representa desde una perspectiva cómica que terminar por estereotipar a ambos grupos, los primeros referentes de la modernidad y del progreso, portadores del conocimiento y de la tecnología. $Y$ los segundos como tipos comunes de una comunidad rural vistos desde su faceta holgazana, ignorante y acomodada a su condición social. El argumento principal discurre en torno a las tareas de prospección petrolífera en que el pueblo se organiza en empresa para competir con el grupo americano. Pero finalmente recibirán una lección moral que refortalece su vínculo con la tierra que habitan. La carrera hacia el progreso de esta comunidad le conduce al punto de partida en que, ante la

\footnotetext{
477 ídem: 43. "Los trayectos entre el pueblo y el escenario fílmico, entre los habitantes y los espectadores, permanece sin resolver". "Drásticamente reformula la forma que en ella prevalece". Traducción de la autora.
} 
imposibilidad de una explotación capitalista de la tierra, solo es posible el aprovechamiento de los recursos naturales, en este caso del manantial de agua que reactivará las tierras baldías. De lo que se concluye, una vez más, la imposibilidad de una riqueza inmediata para el estamento campesino inextricablemente ligado a la tierra que trabaja y habita.

Rafael J. Salvia ahondó en las fórmulas en que representó la comunidad de ¡Aquí hay petróleo! en El puente de la paz, 1958. También en un enclave rural tiene lugar un intento de modernización en que dos pueblos rivales deciden construir un puente sobre los terrenos de un tercero, un campesino y su hija. La mala astucia de los dirigentes encargados del proyecto tiene como objetivo enriquecerse a costa de las rentas del campesino que acabará revelándose por la fuerza. Ante la falta de diálogo, el conflicto se resuelve con la llegada de un cuarto agente mediador, unos extranjeros. En tono cómico Salvia representa una comunidad rural constituida por un elenco de tipos propios en que Manolo Morán vuelve a encarnar al protagonista, un campesino de carácter vivaz y poco trabajador, dueño de un pequeño terruño infértil que se verá recompensado por la bondad de su persona.

En conclusión, la perspectiva cómica con que fueron abordadas las cuestiones de la falta de agua o la tecnificación del campo en los últimos títulos citados supedita estos temas cruciales para el desarrollo del campo español a meras excusas argumentales para desarrollar una narración que bien tendría cabida en cualquier otro marco espacial. A lo que cabe sumar el tratamiento cómico de los arquetípicos comunes de estos espacios que contribuye a su tipificación peyorativa.

De entre la filmografía que abordó la cuestión rural solo el drama rural se constituyó como género cinematográfico. González Requena en Apuntes para una historia de lo rural en el cine español identifica sus elementos constitutivos. Narrativamente oscila "entre la abstracción característica del relato trágico y la concreción del relato costumbrista ${ }^{478 " . ~ A ~ n i v e l ~ s e m a ́ n t i c o, ~ " l a ~}$

\footnotetext{
${ }^{478}$ Aguilar, 1988:15.
} 
presencia de un código moral y de costumbres rígido e inflexible cuya violación -real o aparente- es acusada socialmente como la transgresión de un tabú que amenaza [...] al conjunto social" el cual se articula en base a tres factores: un código rígido contenedor de un tabú, la transgresión del mismo y su publicitación. Unos elementos que definen unos "núcleos sociales pequeños e intensamente interconectados cuya identidad depende esencialmente de su código fundador" y de la presencia del odio "que sustenta y genera las agresiones de las fuerzas narrativas en conflicto y que orienta la focalización del mismo ${ }^{479 " . ~ E l ~ d r a m a ~ r u r a l ~ s e ~ l o c a l i z a ~ e n ~ e l ~ e s t a d i o ~}$ del paisaje dentro de los diferentes usos cinematográficos del espacio rural. Sin embargo, los elementos constitutivos enumerados por Requena se conjugarán para construir un universo referencial solamente válido en las diégesis de cada película, en otras palabras el tratamiento del paisaje en los dramas rurales no comporta establecer similitudes con la realidad del campo español de los años 50.

Como la tierra, 1954, ejemplifica el equilibrio entre la tragedia y el costumbrismo de que habla Requena. En las llanuras castellanas Alfredo Hurtado localiza la tragedia en que María, como la Acacia de La aldea maldita de Florián Rey, reniega de su matrimonio con un humilde campesino huyendo a la ciudad, pero el deber con su familia la obliga a volver para cumplir con su cometido. La insistencia de enmarcar el argumento en un enclave rural se establece en el primer encuadre del filme en que un plano estático muestra a un hombre con su arado, mientras una voz en over sentencia:

"Llanuras castellanas horizontes sin fin, tierra 'fértil donde no germina la mala hierba, tierra de recios hombres nobles y austeros, ásperos y secos en apariencia pero bondadosos y feraces en la realidad, como la tierra. Raza viril que vive sobre esta tierra parda mirando al cielo. De alma tan sencilla como la llanura de sus campos y una fe tan profunda como la raíz de sus regios álamos que no se doblegan ante el empuje de ningún vendaval".

\footnotetext{
${ }^{479}$ lbídem.
} 
Un subrayado verbal que enlaza el tratamiento formal del argumento con las versiones de la Aldea Maldita en que un noble campesino entregado a su condición deberá restablecer el honor familiar mancillado por la vanidad de su mujer huida a la ciudad. El restablecimiento del honor femenino también está presente en la trama de El alcalde de Zalamea de José García Maesso, 1953, sobre la obra de Calderón de la Barca. Y como sucediese en el drama de honor de Florián Rey la ciudad es representada como el reverso del campo, mientras este contiene los buenos valores, la urbe se erige en lugar de perversión como consecuencia de la modernización del país. Finalmente, la protagonista será juzgada por la moral de la comunidad rural: "Acusas al pueblo porque te rehúye sin pensar que la única culpable eres tu, tu que has escandalizado a estas pobres gentes. Tu que has faltado a dos juramentos: al de tu madre y sobre todo al de Dios" le recrimina el párroco. La protagonista de Como la tierra debe morir para no obstaculizar el desarrollo de la vida y con ello de los ciclos de la tierra. El cierre del relato, idéntico al encuadre inicial acompañado de un nuevo relato de la voz en over, constituye la metáfora visual de la vida campesina ligada a la tierra:

"Vuelve la sementara llena de promesas para el futuro, y vuelve la reja a herir la tierra abriendo el surco que acogerá la simiente. Surcos interminables, como las esperanzas de sus hombres. Con la nueva siembra recogerán otra cosecha y una nueva felicidad. Porqué los castellanos son como la tierra prometedora y fértil cuando la simiente es buena".

La línea en que Alfredo Hurtado concibe su arquetipo femenino está presente en otros tantos dramas rurales en que los personajes femeninos originan el conflicto. Otro ejemplo es La Laguna Negra, 1954, Arturo RuizCastillo, inspirado en el poema La tierra de Alvargonzález de Antonio Machado, 1912. En una comunidad rural se sitúa la historia de codicia en que dos hermanos asesinan a su padre con el objetivo de heredar sus propiedades. Candelas, la mujer de uno de ellos, empujada por la codicia es la instigadora del plan. El parricidio pronto adquiere la forma de leyenda al ser cantado por un mendigo. La forma que adopta la tragedia de La Laguna Negra se basa en la mirada de la miseria humana del entorno rural en que la 
inoperancia de las tierras condena a sus habitantes. Finalmente, este melodrama familiar tiene lugar en una comunidad entregada a las labores del campo y las tradiciones festivas, la cual, posee los buenos valores que la legitiman a actuar como jueces ante el crimen acaecido.

Una mujer se encuentra en la base del drama Condenados de Manuel Mur Oti, 1953. La abnegada Aurelia se esfuerza por trabajar las tierras mientras espera el regreso de su marido. La mujer, como las tierras, no encuentra realización alguna hasta la llegada de un hombre que las auxiliará ya que Aurelia y la tierra se constituyen en un todo apelando a la metáfora del ciclo agrario en que se concibe la puesta en imágenes del paisaje castellano. Un ejercicio de depuración formal de la cuestión metafísica ya iniciado en Un hombre va por el camino de 1949 en que se situaba a una mujer sola ante unas tierras hostiles, metáfora de una sociedad que la ha rechazado. Cuestiones analizadas en profundidad en el capítulo siguiente.

En la línea temática de la mujer maltratada por el entorno natural también se sitúa Duelo de pasiones de Javier Setó, 1956. Su protagonista ejemplifica la vejación del estamento campesinado ante las inclemencias de las oligarquías locales, si bien esta cuestión queda supeditada al drama de honor sufrido por la mujer. Esta película junto a El puente de la paz abre una vía dentro del drama rural al interesarse por el estado social de las comunidades rurales.

También en el arquetipo femenino concentra Antonio del Amo su mirada sobre el entorno rural en Sierra maldita, 1954. La versión cinematográfica de una leyenda que estigmatizaba a las mujeres de la sierra almeriense como paradigma de una comunidad aldeana mirada desde su faceta vetusta, es decir, anclada en las supersticiones y los rituales en oposición al transcurso del tiempo. Cuestiones analizadas en el capítulo siguiente.

Finalmente, la primera parte de La venganza de Juan Antonio Bardem, 1957, se construye en base a los elementos del drama rural al presentar a dos familias enfrentadas por un odio pretérito. Una mujer fue la causa de un 
crimen pasado, y en el presente narrativo dos mujeres de sendas familias se afanarán por perpetuar la rivalidad aun viéndose obligadas a trabajar conjuntamente. Esta cuestión ocupará el resto del metraje derivando el drama rural en una vertiente social, que ejemplifica el segundo caso de análisis en que el espacio rural es tratado como territorio.

Basada en la novela de Elena Quiroga, Premio Nadal 1951, Antonio Momplet versionó Viento del Norte, 1954. Es la historia de Marcela, una joven huérfana en un pazo gallego, lugar que funciona como metonimia de la vida rural de esta región como demuestra la inclusión de expresiones y actitudes características de las gentes gallegas, la presencia del arquetipo de las meigas o el trabajo de las viñas. La mirada costumbrista con que se construye Viento del Norte discurre a partir del melodrama surgido de la historia de amor interclasista entre la protagonista y el señorito de la finca.

Juan de Orduña también abordó el regionalismo valenciano a partir de la obra literaria de Blasco Ibáñez Cañas y barro, 1902. La versión fílmica de 1954 ponía en imágenes la Albufera valenciana habitada por una comunidad subsidiaria de los recursos del entorno: la pesca y la siembra del arroz. La representación naturalista de esta comunidad rural -siguiendo los imperativos de la obra original- discurre a partir de la trama amorosa entre sus protagonistas. Finalmente, cabe destacar la construcción del arquetipo femenino en la línea de las protagonistas de Condenados y Sierra maldita, como se analiza en el capítulo siguiente.

El odio, elemento constitutivo del drama rural, es el factor primario de la trama de Nosotros dos de Emilio Fernández, 1954. La rivalidad entre las familias Pedrosa y Avilés dificultará el amor entre sus respectivos hijos. El hecho que la trama se localice en un enclave rural corrobora la tesis de González Requena en cuanto que "el contexto rural define la singular especificidad de su registro dramático 480 ". La voz en over asenta la perspectiva desde la que se aborda este drama rural:

480 lbídem. 
"Esta es una historia de amor y de odio. De odios ancestrales, vengativos, estériles. Y de amor juvenil, fecundo y redentor. La eterna lucha del bien contra el mal. El odio contra el amor. Nuestra historia comienza en un atardecer de verano cuando una carreta desvencijada se aproxima a un pueblo, cualquier pueblo, conduciendo a dos mujeres.

La presencia del narrador subraya la condición de relato de ficción de Nostros dos, por lo que la mirada verista de las aproximaciones a los modos de vida rurales de queda supeditado al desarrollo narrativo de la tragedia.

El problema de la sequia se encuentra en la base argumental de Orgullo, 1955. Una cuestión específica del entorno rural que Manuel Mur Oti aborda desde las fórmulas del western a través de la poética de los grandes espacios, las disputas entre ganaderos y la conducción de las reses ${ }^{481}$. Pero también del drama rural puesto que el odio es el factor determinante de la existencia de dos familias de terratenientes imposibilitando el acercamiento de las nuevas generaciones. El entorno rural de Orgullo funciona como referente identitario para las familias protagonistas, aferradas al honor de su estirpe en relación al territorio que poseen. En palabras de Zunzunegui "el relato de Orgullo [puede] ser transcrito en términos de la oposición entre la tierra y el agua, mientras que los personajes se consumen en el fuego de una pasión que únicamente encuentra paz en el aire de las cumbres ${ }^{482 " . ~}$

Existe un grupo de películas que sitúan sus tramas argumentales en el enclave del pueblo, esto es en el seno de pequeñas comunidades rurales que constituyen cierto estado de avance sobre los núcleos aldeanos. Atendiendo a los postulados del sociólogo Galeski por los que el entorno natural determina los modos de vida de los habitantes de un lugar, el pueblo constituye un estadio de comunidad social rural en que se también se sitúan las tramas de Bienvenido Mr. Marshall, ;Aquí hay petróleo! o Las aguas bajan negras dando opción a la representación de un amplio corpus de arquetipos. El andén de Eduardo Manzanos, 1952, Cancha vasca de Alfredo Hurtado,

\footnotetext{
${ }^{481}$ Santos Zunzunegui en Pérez (Coord.). 1997: 373-376.

482 Ibídem.
} 
1954, Calabuch de Luis G. Berlanga, 1956, Soledad de Enrico Gras y Mario Carveni, 1958 se centran en establecer sus variados argumentos en un corpus de tipos que ejemplifican las jerarquías, los modos de vida y rituales festivos propios de estos núcleos sociales.

Finalmente El ruiseñor de las cumbres de Antonio del Amo, 1958, constituye un caso excepcional de cine musical de esta década ubicado en un espacio rural. Dentro de la vertiente de lo popular, esta película supone un giro temático en la trayectoria del Amo respecto a la anterior Sierra maldita. Bajo la fórmula del melodrama se cuenta la historia de un joven pastor desamparado y obligado a explotar sus habilidades para el cante con la finalidad de recomponer su núcleo familiar. En referencia al simbolismo del espacio rural Alberto Elena concluye que El ruiseñor de las cumbres, y en conjunto la filmografía de Joselito, aluden a una España ideológicamente conservadora, de profunda religiosidad, solidaria y de buenos sentimientos que acaba por constituir "un inventario de valores y apología de un ethos de perfiles bien reconocibles ${ }^{483 "}$.

Historiográficamente este corpus cinematográfico ha recibido desigual atención debido, principalmente, a la inexistencia de estudios específicos sobre cine rural español. Como referentes excepcionales se han encontrado el texto de González Requena en el catálogo de la muestra de carteles "EI campo en el cine español ${ }^{484 ",}$ un somero recorrido por cuanto pretende, en un espacio limitado, abarcar toda la producción de cine rural nacional hasta la década de los ochenta. Y las publicaciones de las actas de las Muestras de Cine Rural de Dos Torres en Córdoba que han abordado buena parte de los títulos más representativos de la historia del cine rural.

Ante la escasez de trabajos previos, el reto de este trabajo ha sido rastrear las referencias a las películas rurales en prensa generalista y publicaciones especializadas de la época así como en los monográficos sobre los

\footnotetext{
483 Elena en Pérez (Coord.) 1997: 446-448.

${ }^{484}$ En Aguilar, 1988.
} 
realizadores españoles. De entre los autores que mostraron especial atención a la cuestión rural se constata una jerarquía en los estudios, más cuantiosos sobre Luis G. Berlanga, Juan de Orduña, Manuel Mur Oti o Juan Antonio Bardem en detrimento de otros dedicados a Ladislao Vadja, Antonio del Amo, José María Forqué o Rafael J. Salvia. Aunque si bien es cierto, el interés por la cuestión rural en la filmografía de un autor ha sido puntual, como sucede en Antonio Momplet, Rafael Torrecillas y Margarita Aleixandre o Miguel Lluch.

La heterogeneidad de fórmulas desde las que el cine español ha abordado el espacio rural corrobora su complejidad como ya advirtieron Lefebvre, Richardson o Davies. Un acercamiento historiográfico requiere de una mínima clasificación que, sin pretender establecer categorías formales ni semánticas que dirijan sus posibles interpretaciones, constituye el punto de partida para un análisis de casos guiado por sus particularidades constitutivas.

En conclusión, de la asimilación de las teorías de los autores anglosajones sobre los usos espaciales y sus significados, en primer lugar se han relacionado aquellas películas de la vertiente folklórico-popular con una mirada percibida del entorno rural que a nivel formal funciona como espacio para el desarrollo de las narraciones. En segundo lugar, los títulos de drama rural constituyen una mirada concebida en base a la incidencia del entorno natural en la definición de los tipos rurales y sus modos de vida. Este es el paisaje, el cual en "el contexto rural define la singular especificidad del registro dramático ${ }^{485 " . ~ Y ~ e n ~ t e r c e r ~ l u g a r, ~ a q u e l l a s ~ p e l i ́ c u l a s ~ q u e ~ h a n ~ t o m a d o ~ l a ~}$ casuística real del campo español como fundamento de sus argumentos, en cuyo caso el espacio rural funciona como territorio. Estas divisiones no son estancas, pues como sucede en la forma del territorio en las películas sobre los problemas del agua ciertos fragmentos del metraje hacen un uso del espacio rural en términos de territorio aunque el desarrollo narrativo discurre sobre otras fórmulas. Sin embargo solo las obras de Muñoz Suay y Bardem constituyen miradas vividas del campo español como referente para la

\footnotetext{
${ }^{485}$ Aguilar, 1988: 15.
} 
reflexión del devenir de la cinematografía y de la vida española. En definitiva, esta propuesta de ordenación del cine rural de los años cincuenta permite apreciar la evolución del uso espacial y su significación en el preámbulo a la modernización del país.

El interés de este trabajo se concentra en los dos últimos estadios de uso del espacio rural, es decir, cuando este emerge como paisaje y territorio por cuanto constituye una entidad cultural de compleja naturaleza. Esta tesis se pretende demostrar a partir del análisis comparado de las películas Condenados, Cañas y barro y Sierra maldita. A nivel narrativo los tres títulos abordan la cuestión rural a partir del vínculo ontológico mujer-tierra que Mur Oti interpreta desde la vía metafísica, mientras que de Orduña sigue la estela del naturalismo literario. $Y$ del Amo parte de las fórmulas de la leyenda para actualizar el imaginario rural de la vertiente folklórico-popular dotándolo de dimensión social. Y del análisis comparado de Amanecer en Puerta Oscura, La guerra de Dios y La venganza se pretende ahondar en los usos del espacio rural como territorio de conflict social. Dos ejes conceptuales que constituyen dos vías de acceso a un corpus fílmico en que sus huellas de ruralidad trascienden a una dimensión político-cultural leída ya por la crítica de la época en clave de construcción identitaria y la cual, hoy en día, permite indagar en el valor simbólico del paisaje, aquel que en la línea de Ann Davies evoca nociones de España, una entidad en continua formación. 


\section{El entorno rural español. Paisaje del drama rural}

El drama rural nació en el ámbito teatral ya en tiempos de Lope de Vega y Calderón de la Barca, y experimentó un gran auge en los siglos XIX y XX. De ahí que las primeras versiones fílmicas fuesen adaptaciones de obras originalmente teatrales entre las que destacan La Dolores de José Feliu i Codina, 1895, adaptada en tres ocasiones por Enrique Jiménez, 1908, Maximiliano Thous, 1923 y Florián Rey, 1939. Terra Baixa de Ángel Guimerá, 1896, adaptada por primera vez por Fructuoso Gelabert en 1907 sirviendo de base para la versión de Leni Riefenstahl, Tiefland, 1954. Juan Vilá Vilamala adaptó el mismo año de su publicación Nobleza Baturra de Joaquín Dicenta, 1925, y en 1935 lo hacía Florián Rey con Imperio Argentina como protagonista. La pieza de Jacinto Benavente, La malquerida, 1913, contó con varias adaptaciones internacionales: la estadounidense de Herbert Brenon, The Passion Flower, 1921; la mexicana de Emilio Fernández, 1949, con Dolores del Río y Pedro Armendáriz en los papeles protagonistas, y la versión española a cargo de José López Rubio en 1939. Benito Perojo dirigió en 1929 La bodega basada en la obra homónima de Vicente Blasco Ibáñez, 1905. Autor valenciano, exponente de la vertiente literaria del naturalismo, también llevado al cine por Juan de Orduña en Cañas y barro, 1954, y a la televisión en el serial La barraca, 1998, dirigido por León Klimovksy.

\subsection{La dimensión telúrica del arquetipo femenino}

En 1857 Millet presentaba en el Salón de París su segunda obra titulada Las espigadoras, en apariencia una mirada bucólica de la tarea de estas trabajadoras del campo. 


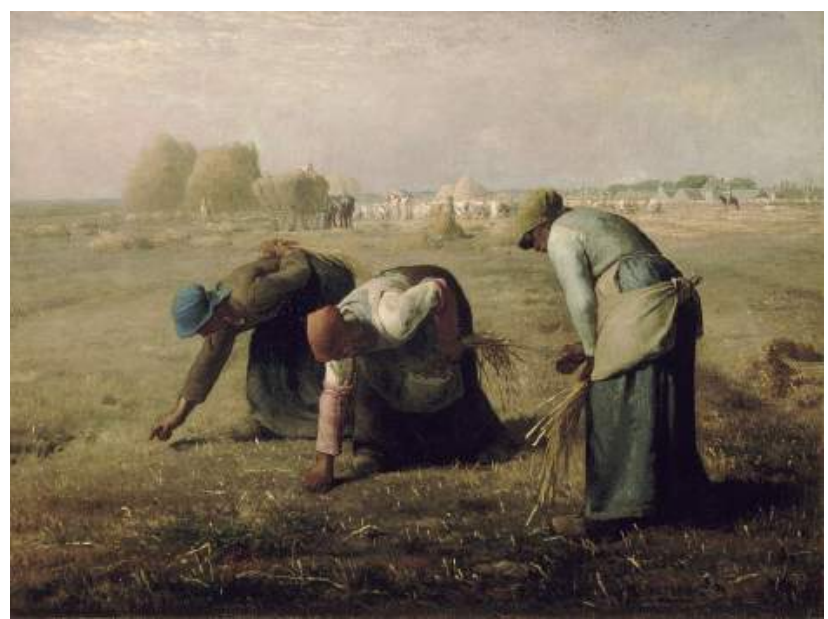

Compositivamente, en primer plano, y a distancia del grupo del fondo, las tres protagonistas de la composición se agachan en su gesto habitual para recoger las espigas sobrantes del rastrojo. Las figuras quedan por debajo de la línea del horizonte y su postura impide identificar con claridad su rostro. Una composición que, en opinión de la profesora Carmen Gracia, adquiere una doble interpretación. Por un lado es una "crida muda dels canalles i els miserables" y por otro son vistes com "bèsties de presa perilloses, amb gests violents que amenaçaven els mateixos fonaments de la societat ${ }^{486 " . ~ L a ~}$ segunda de las lecturas se debe a la pertenencia de estas mujeres a la clase social más baja del campesinado aquella que accedía al sobrante de los campos una vez recolectados. Teniendo en cuenta esta información, la mirada bucólica del lienzo adquiere una dimensión crítica en torno a la jerarquía económico-social rural imperante en la década de 1850 en que "Millet contribuiia a donar imatge a un poder social que va començar a manifestar-se a la Revolució de $1848^{487 "}$. Más allá de la dimensión política de la obra del pintor normando acusado con su posterior El hombre de la azada, 1863, de "demòcrata, agitador perillós i anarquista determinat a provocar una revolta popular" y por ello vetado en el Salón de París de ese año, la voluntad original de Millet empieza por ennoblecer el gesto ordinario de las protagonistas del lienzo. El lienzo de Millet aúna las dos vías semánticas escogidas para abordar el tratamiento cinematográfico del paisaje y el

\footnotetext{
${ }^{486}$ Gracia, 2000:131.

${ }^{487}$ Ibídem.
} 
territorio rural español: la presencia de la mujer y de las tareas propias del campo.

El legado literario de Federico García Lorca respecto al imaginario rural español se centra en el subrayado del vínculo ontológico mujer-tierra. Sus poderosos personajes femeninos, alcanzan su máxima expresión en los personajes de La Novia de Bodas de Sangre, 1933, y de Yerma en la obra teatral del mismo nombre, 1934. Estas 'mujeres lorquianas' comparten el vínculo con la tierra que habitan, un paisaje árido que pronto consume su vitalidad, aislándolas en un marco ingrato y haciéndolas vulnerables ante la voluntad patriarcal imperante.

El análisis de los casos fílmicos de este capítulo está regido por dos hipótesis. La primera se refiere a la idea del entorno rural como ese "algo más que el paisaje de un drama genérico", y que implica rastrear aquellas huellas de ruralidad que traspasan el marco espacial para definir "la singular especificidad de su registro dramático ${ }^{488}$ ". Y la segunda se refiere a la concreción del arquetipo femenino ya apuntado cinematográficamente por Florián Rey en su primera versión de La aldea maldita, 1930, en que ponía en imágenes "una relación casi metafísica entre la tierra y la mujer"489", la primera infértil y azotada por las inclemencias climáticas y la segunda condenada por su irreverencia y deshonra hacia su familia.

En el marco teórico para este apartado se sitúa el trabajo de Nira YuvalDavis en Gender \& Nation, que sitúa el vínculo mujer-tierra a partir de lo que llama 'genetic pools' refiriéndose a aquellas comunidades imaginadas en que sus integrantes se identifican por los valores, religiones y modos de vida que comparten. La unión mítica de estas comunidades imaginadas presupone un enfrentamiento entre 'el nosotros' y 'lo Otro' en que las mujeres se erigen en "symbolic border guards", expresión utilizada por Armstrong en Nations before Nationalism, $1982^{490}$. A esta primera función del género femenino se le

\footnotetext{
488 Aguilar, 1988: 15.

489 Sánchez, 1991: 356.

490 Yuval- Davis, 1997: 26-38.
} 
suma un segundo rol 'natural' dada su condición como generadora de vida, de ahí el vínculo con la tradición mitológica de la tierra. Dos vertientes de las facetas del género femenino presentes en los argumentos de las siguientes películas.

En la década de los cincuenta irrumpía en el panorama cinematográfico Manuel Mur Oti quien, desde su primera película en 1949, Un hombre va por el camino como en las siguientes, Condenados, 1953, Orgullo, 1955, Fedra, 1956, y Duelo en la cañada, 1959, mostraba especial interés hacia la cuestión rural. Nekane E. Zubiaur engloba los primeros cuatro títulos mencionados bajo el epíteto 'tetralogía de la tierra', argumentando que:

"No es posible [...] encontrar [...] una descripción más o menos costumbrista o documental de las tradiciones campesinas españolas, ni la exaltación bucólica del paisaje, ni la presentación de los resortes de un eterno conflicto social entre clases, porque lo que rige sus narraciones es siempre el deseo de y por una mujer erguida sobre una tierra que es a la vez su alimento y su condena, y que se resiste visceralmente a abandonarla ${ }^{491 " \text {. }}$

De la tesis de Zubiaur se deduce que estas películas de Manuel Mur Oti, y en concreto Condenados, se erigen en paradigma de la vía metafísica como método para la representación cinematográfica del paisaje rural. Una vía que, a nivel temático, comparte ciertos elementos con la adaptación cinematográfica de Juan de Orduña sobre la obra homónima de Vicente Blasco Ibáñez, Cañas y barro, y la película de Antonio del Amo, Sierra maldita, ambas estrenadas en 1954. En conjunto, tres películas protagonizadas por arquetipos femeninos cuya presencia rige el desarrollo narrativo de unos dramas rurales en los que la consecución de una cosecha o las tareas de extracción del carbón materializan los ciclos de la tierra siempre en relación con el devenir personal de sus respectivas protagonistas.

Esta coincidencia temática constituye el punto de partida para el análisis de estos tres casos entendidos como tres acercamientos al género del drama

${ }^{491}$ Zubiaur, 2013: 226. 
rural, basados, narrativamente, en el conflicto entre el género masculino y el femenino, el cual, es llevado a su extremo más pasional justamente por situarse en un espacio rural aislado. En Condenados destaca la depuración formal de la cuestión metafísica en que el emplazamiento rural castellano, más que apelar al elemento inmediato de cotidianidad, hace aflorar la razón de ser primaria de la condición humana. Mientras que en Sierra maldita y en Cañas y barro la tragedia pasional también alberga el desarrollo de tramas secundarias que dan cuenta de la dimensión social de la comunidad rural y de los avatares derivados del propio entorno natural.

Para la historiografía cinematográfica la figura del vigués Manuel Mur Oti resulta controvertida debido a su condición de autor, inusual para la época. Las declaraciones del realizador se respaldaban en una filmografía donde la continuidad de estilo hacia reconocible, ya en la primera etapa de su producción, "las marcas enunciativas de su autor ${ }^{492 " . ~ N o ~ o b s t a n t e, ~ l a ~ c u e s t i o ́ n ~}$ 'autor', sobrepasa los límites de este análisis por lo que a modo de síntesis se citan las palabras del historiador del cine Julio Pérez Perucha:

"En los márgenes de maniobra que nuestro cine facilitaba [Mur Oti] consiguió poner en pie un conjunto de películas en donde las más de las veces emergía con inusual potencia no solo un original universo considerablemente alejado de las propuestas que conformaban la fisonomía habitual del cine hispano, sino que tales propuestas hacian acto de presencia a través de la densidad fílmica, que siempre acredita el trabajo de un cineasta alejado de la rutina muchas veces imperante en cualquier cinematografía ${ }^{493 " . ~}$

En Condenados el ejercicio de puesta en escena del conflicto primigenio mujer-hombre, como paradigma de la tetralogía rural del cineasta, cumple con los tres elementos que Zubiaur identifica como los pilares formales del género. "El tono mítico, la opción del drama rural como género matricial que configura la narración, [y] la preeminencia de la mujer (sujeto agente de la

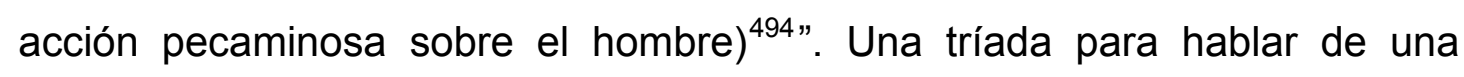

\footnotetext{
492 En Castro; Pérez, 1999: 12.

493 Ibídem.

494 Zubiaur, 2013: 222.
} 
nueva vía dentro de las formas cinematográficas del cine español de los años cincuenta que Santos Zunzunegui denomina 'veta del mito', localizada en el terreno estético de la estilización o el simbolismo, por oposición al realismo. De este modo, en Condenados recurre a:

\begin{abstract}
"Esquemas míticos y de arquetipos narrativos en lugar de personajes psicológicamente definidos; la aparición de referencias a toda una serie de elementos de corte simbólico susceptibles de desviar el relato de cualquier realismo a ras de suelo; [...] la ausencia de cualquier localismo, y la voluntad de escribir los relatos en el interior de ciclos y elementos naturales capaces de conferirles un sentido más vinculado con una dimensión telúrica y genérica de las cosas que con una determinación concreta y directamente realista de los acontecimientos $^{495 "}$.
\end{abstract}

De hecho la ausencia de elementos sociales interpretables en términos veristas queda patente ya en las modificaciones introducidas en la versión fílmica respecto a la obra teatral original. De entre los cambios más significativos destaca la delimitación del corpus actoral de los diecisiete personajes de la obra de Suárez Carreño ${ }^{496}$ a los cinco de la versión fílmica de Mur Oti, además de concentrar el peso dramático en el trío protagonista. Un cambio formal que limita las posibilidades de desarrollo de argumentos secundarios, relegando al resto de personajes a una función coral, cuanto menos localizadora del espacio rural. Una presencia, por otra parte, limitada a las secuencias de la liturgia religiosa al principio del filme y a la escena de enfrentamiento de Aurelia con los hombres que rehúsan trabajar sus tierras. Formalmente estos son introducidos como una masa homogénea que da la réplica a la protagonista. En definitiva, los demás personajes de la versión fílmica de Condenados, con sus vestimentas y caracteres, remiten al arquetipo del campesino aunque la ausencia de un desarrollo psicológico individual, tal como ocurría en la versión teatral de Suárez Carreño, reafirma

\footnotetext{
${ }^{495}$ Castro; Pérez, 1999: 22-25.

${ }^{496}$ La obra de Suárez Carreño fue publicada por Ediciones Alfil en 1952, y en la enumeración del reparto se cuenta, además del trío protagonista, la tía Teresa, Ignacio, Salvador, Manuel, Dolores, la madre de Matías y ocho personajes secundarios. Cabe tener en cuenta la presencia de los personajes femeninos de La tía Teresa y Dolores como núcleo afectivo de la protagonista además de Vicenta, la madre de Matías que funciona como recurso formal para conocer el crimen del pasado.
} 
su función coral. Finalmente, en la versión cinematográfica la limitación del corpus protagónico a tres personajes elimina el entramado de relaciones existente en la obra teatral que da cuenta del entorno afectivo en que conviven José y Aurelia, facilitando la inclusión de la mujer en el vecindario. Un factor de que carece la versión fílmica la cual, por su parte, ahonda en la estigmatización de la condición femenina del personaje mediante su marginación social.

El propio Mur Oti mostró interés por vincular su obra a la herencia de Federico García Lorca, pero el crítico de Objetivo Eduardo Ducay negó tal posibilidad argumentando que "es lástima, pues, que este tema reiterado, al no aparecer dotado de observaciones sociales que le podrían dar considerable interés, quede reducido a variaciones folletinescas 0 románticas $^{497}$ ". Mas, a excepción de Ducay el resto de críticos coincidían en establecer la genealogía del drama rural de Mur Oti remontándose a la tradición clásica:

"Como una tragedia griega de celos localizada en áspera Castilla, con lo que trama, tipos y episodios se nos ofrecen con una gran rudeza que da a la obra un sello singularísimo, inconfundible, y constituye pues, impresionante espectáculo, esencialmente original $^{498 " \text {. }}$

Unas lecturas que llegaron a establecer lazos con el imaginario cervantino, "Castilla, tierra de profundidad de ensueño, de caminos sin fin, de posadas esporádicas, como de aduar, de molinos como gigantes que vigilan, avisan y esperan... Salida quijotesca la de esta nueva productora, por los puros anhelos de arte que demuestra en su primera obra cinematográfica ${ }^{499 " . ~ D o s ~}$ posicionamientos que ilustran el debate que generó Mur Oti en su particular representación del paisaje rural español depurado de todo elemento social.

\footnotetext{
497 Objetivo. Núm.2. Enero de 1955.

${ }^{498}$ Primer Plano. Núm. 673. Año XIII. 6 de septiembre de 1953.

${ }^{499}$ Primer Plano no identificado.
} 


\subsection{Condenados, 1953 , el paisaje castellano}

Condenados es la obra teatral escrita por Jesús Suárez Carreño en 1951 y versionada por el cineasta Manuel Mur Oti dos años más tarde. Cuenta la historia de Aurelia -Aurora Bautista, una mujer que se esfuerza en trabajar las tierras de su hacienda durante la ausencia de su marido. A la protagonista se une Juan -José Suárez- cuya ayuda le permitirá poner en funcionamiento el molino de trigo y aumentar el ganado. La urgencia por contratar mano de obra para la recogida de la cosecha propicia la visita de Juan al pueblo en busca de hombres, pero pronto descubre que ninguno está dispuesto a trabajar en las tierras conocidas como 'del condenado'. Y es que José -Carlos Lemos, el marido de Aurelia, ha sido encarcelado por matar a un hombre que osó mirar a su esposa. Los vecinos del pueblo temen el gatillo fácil de José, y quieren evitar cualquier tentativa. No es el caso de Juan, que se crece en su empeño por demostrar su lealtad a Aurelia. Finalmente, patrona y trabajador acuerdan prolongar su contrato cinco años más, pero la llegada anticipada de José trunca sus planes. El marido regresa moralmente destrozado e invadido por el miedo a perder a su mujer ante la presencia de otro hombre. Aurelia se esforzará en demostrar su compromiso con el marido pero todo intento será en vano ya que Juan desvelará sus sentimientos por la mujer obligando a los dos hombres a batirse en duelo a navaja por su amor.

Siguiendo la estela de Un hombre va por el camino, 1949, el argumento de Condenados parte de "idéntica situación: la de la mujer abandonada, sola

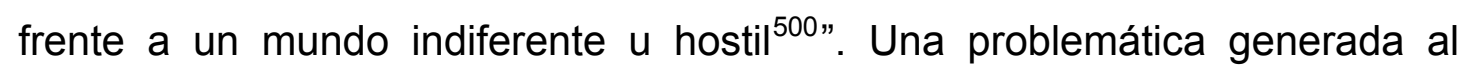
situar la trama argumental en un enclave rural interpretado desde la aridez de su geografía. Ilustrativo al respecto son los titulares de los artículos publicados en su momento en que se describía el lugar como una "desamparada llanura manchega", de "secas parameras castellanas ${ }^{501}$ "; "el escenario de Condenados, la Mancha, con sus eras, sus eriales, sus sembrados ralos, sus cerros pelados y sus molinos espectrales; la fea

\footnotetext{
${ }^{500}$ Objetivo. Núm.2. Enero de1955.

${ }^{501}$ Primer Plano. Núm. 673. 6 septiembre de 1953, año XIII.
} 
Mancha, con su magnífica belleza propia ${ }^{502 ", ~ o ~ " C a s t i l l a ~ s e c a ~ e n ~ u n ~ d u r o ~}$ estío... Desolación infinita en los campos y en las almas ${ }^{503 " . ~}$

Mur Oti, "apasionado romántico de lo real, inmediato y concreto" ${ }^{504}$, consideró esencial llevar el rodaje de Condenados:

"A las estepas de La Mancha y en pleno estío, en polvorientas eras, sembrados enteros y llanos desamparados, los artistas y el equipo técnico han soportado los más duros rigores. Pero esta misma dureza será la que habrá de dar al film el realismo extremado que exige y que lo sellará con una auténtica originalidad ${ }^{505 " \text { ". }}$

También "los productores de Condenados [conocían] perfectamente el valor de la autenticidad y la cotización del esfuerzo" ${ }^{506}$ de rodar en los exteriores naturales de Argamasilla de Alba y Tomelloso bajo el sol de agosto. Unas condiciones de trabajo inusuales para la industria acostumbrada a rodar en platós en las condiciones anteriormente descritas.

Formalmente, el drama rural de Condenados comienza con una melodía orquestal de carácter intenso y ritmo acelerado. Un fundido negro se abre para mostrar la imagen de una gran llanura de aspecto árido que se extiende en la profundidad de campo. Una figura ataviada con ropas negras rompe la harmonía visual del encuadre repitiendo la acción de surcar el terruño con una azada (fig. 1). Por corte seco se enlaza con un plano medio de la figura, una mujer, que con gesto fatigado se detiene a coger aliento mientras se gira sobre sí misma para contemplar la inmensidad del paisaje que la rodea (fig. 2).

\footnotetext{
502 Primer Plano, julio de 1955, año XV, núm. 772.

${ }^{503}$ Primer Plano, 25 octubre de 1953, año XIII, núm. 680.

504 Primer Plano, no identificado.

${ }^{505}$ Primer Plano, 25 octubre de 1953. Año XIII, año 680.

${ }^{506}$ Primer Plano. No identificado.
} 


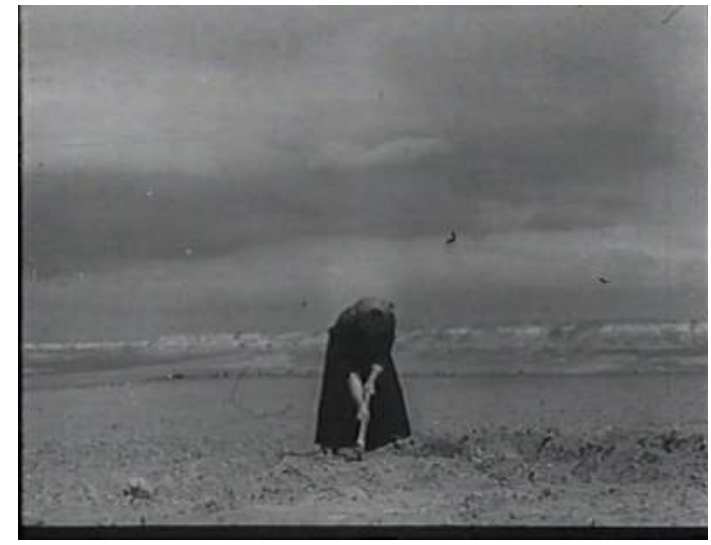

Figura 1

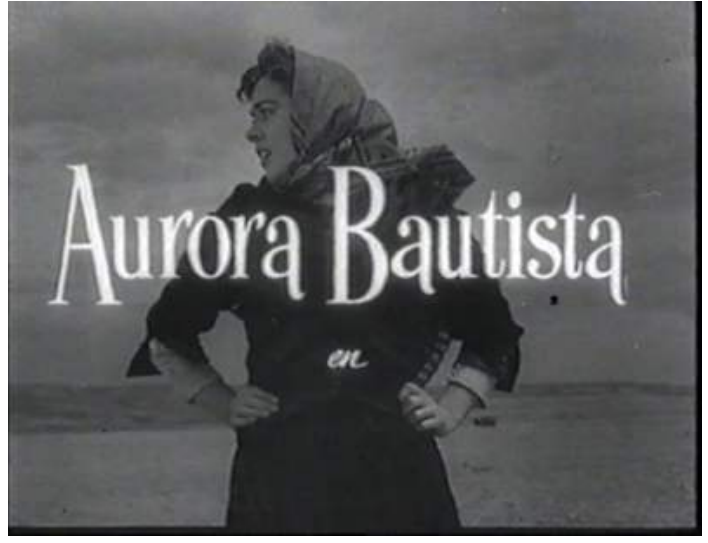

Figura 2

Sobre la imagen de la mujer se superpone el nombre de la actriz -el primer texto tras el logotipo de la productora, detalle significativo en el subrayado de su protagonismo en el conjunto del filme. Mientras toma la azada y se adentra en la profundidad de campo se suceden el resto de créditos (fig.3).

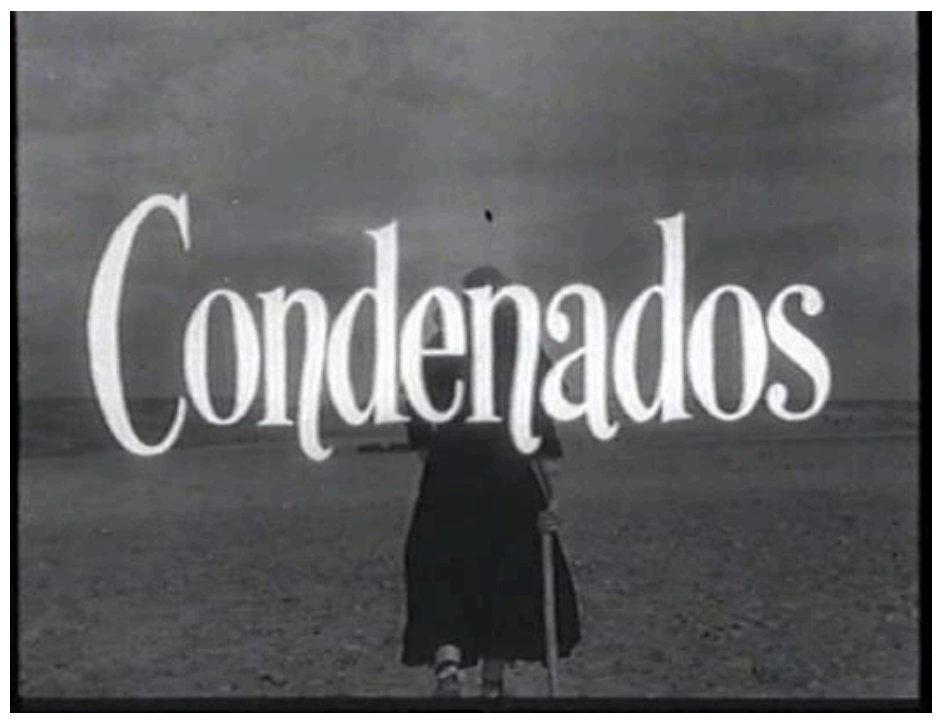

Figura 3

La mujer carga la herramienta al hombro y aligera el paso hasta llegar a un camino. En su andadura se encuentra con otros trabajadores del campo que realizan el mismo trayecto. Se suceden una serie de planos cerrados en que la centralidad del cuerpo de la protagonista domina los encuadres por los que transitan campesinos con sus animales (fig.4a y b). El último plano de esta secuencia es una cámara fija desde una posición baja que encuadra una 
vista amplia del camino pedregoso por el que se alejan los campesinos seguidos de la protagonista (fig. 5).

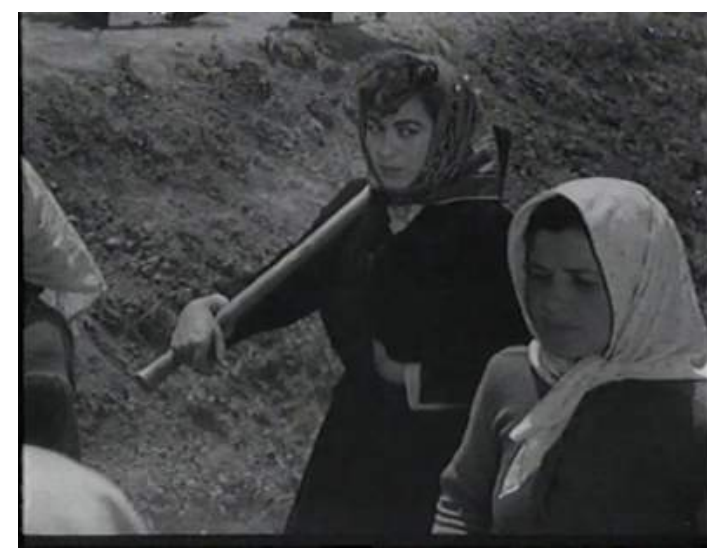

Figura 4a

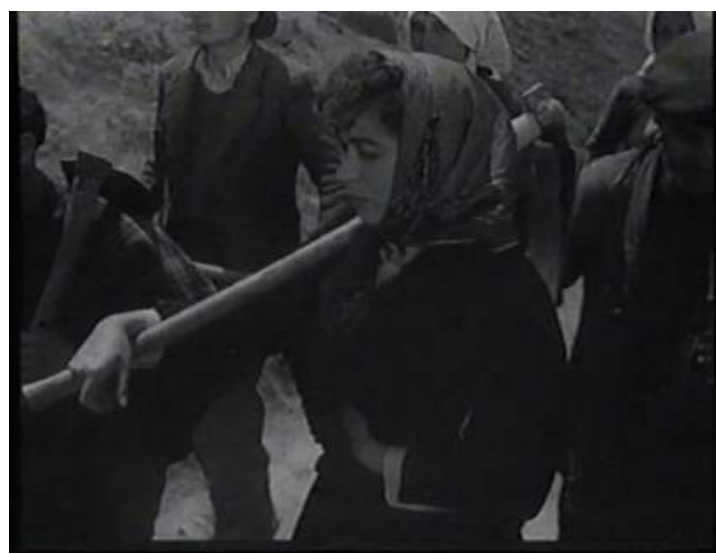

Figura $4 b$

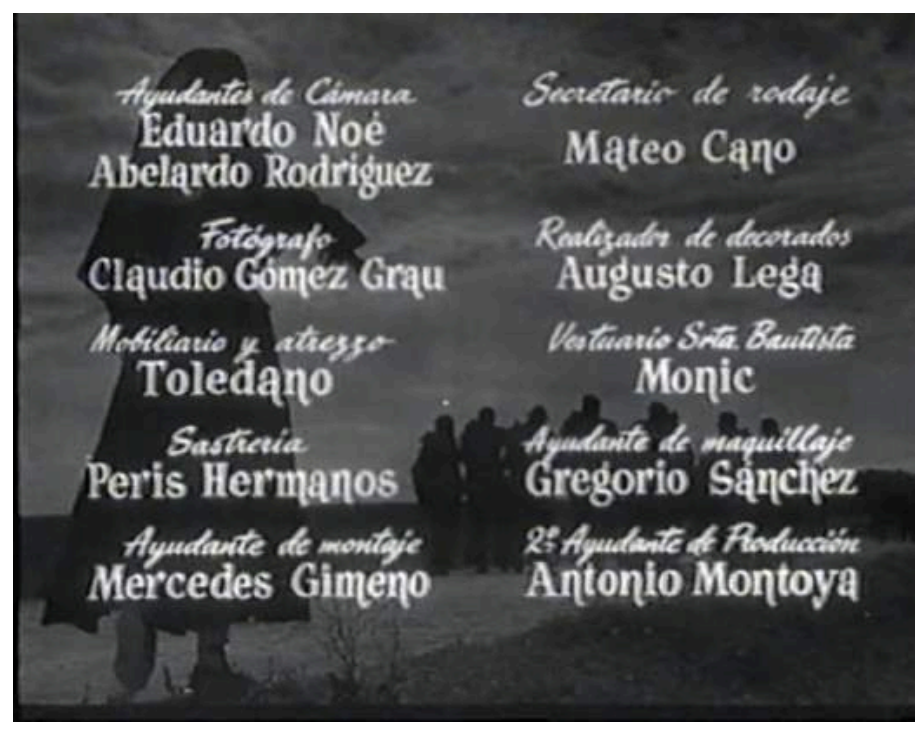

Figura 5

La puesta en escena de esta primera secuencia es una declaración de intenciones que fija el foco de interés en el personaje femenino de Aurelia y en el paisaje rural, o viceversa. En un momento determinado la protagonista se detiene a observar su alrededor produciéndose una doble mirada articulada a través del punto de vista del personaje que, a su vez, emplaza al espectador a mirar el espacio natural. Esta doble mirada subraya la voluntad 
del realizador por ordenar el entorno y convertirlo en paradigma de la ruralidad castellana aunque, si bien es cierto, la ausencia de localismos impide identificaciones concretas. Un tratamiento del paisaje defendido por el propio Mur Oti, "Yo no era el típico español haciendo el cine folclore del que huía, como del otro cine al uso en aquellos tiempos. [...] Yo quise hacer un cine de condición universal ${ }^{507 " \text { ". }}$

\subsection{Sierra maldita, 1954 , el paisaje andaluz}

El argumento de Sierra maldita surge de la leyenda de la Niña Negra sobre la infertilidad de las mujeres de Puebla de Arriba, en la sierra almeriense. Las jóvenes de esta aldea viven estigmatizadas por esta leyenda que planteará el conflicto en la historia de amor entre Cruz -Lina Rosales- y Juan -Rubén Rojo, vecino de Puebla del Valle. Los dos jóvenes se casan pero la presión diaria de los vecinos les lleva a unirse a una cuadrilla de carboneros que trabaja en las inmediaciones de la cumbre de la Niña Negra. Tras los primeros meses de trabajo, el frío y el aislamiento hacen mella en los hombres del grupo poniendo en su punto de mira a Cruz, hasta que una noche dos de ellos intentan agredirla sexualmente. Cruz huye y se refugia en la cumbre de la Niña Negra. Finalmente el agresor y Juan se batirán en duelo y ella será redimida del estigma de la infertilidad con la posibilidad de concebir un hijo.

Una vez más la secuencia inicial asienta los preceptos en que el paisaje será representado. Sobre dos fotos fijas de un paisaje montañoso se introducen los títulos de crédito (fig. 6a y b).

$\overline{{ }^{507} \text { Arte Fotográfico, núm. 354, } 757 .}$ 


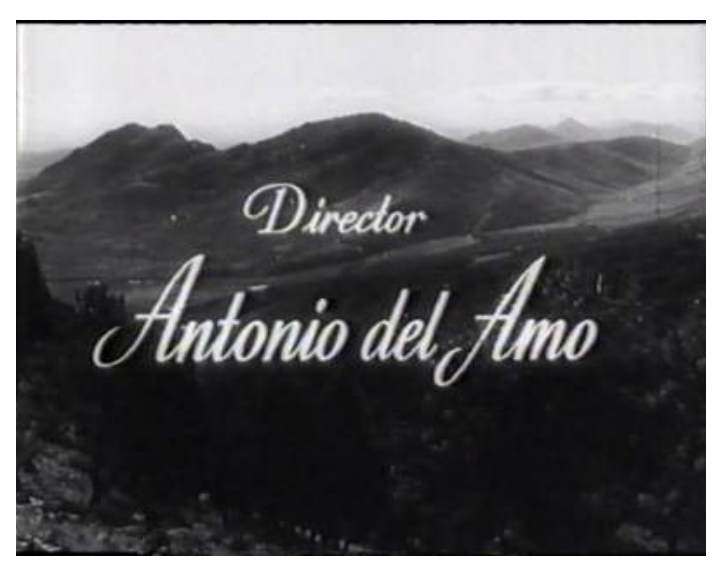

Figura 6a

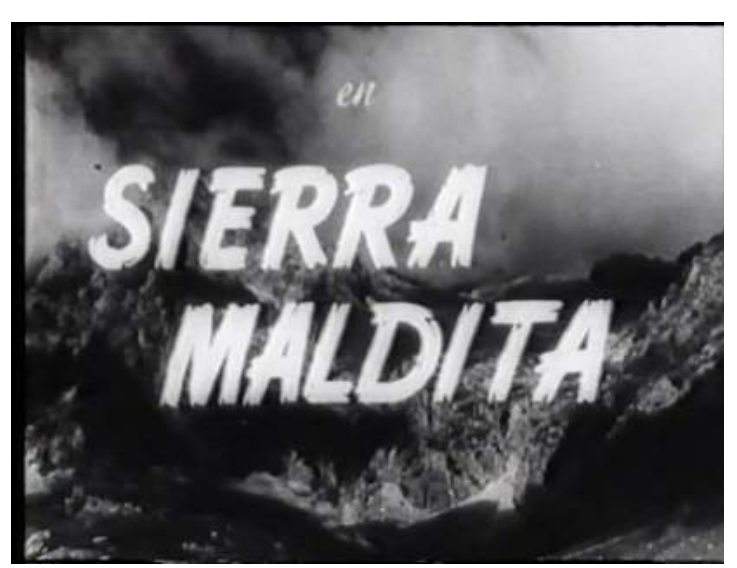

Figura 6b

La sucesión de estas imágenes se rige por el desarrollo de una pieza musical extradiegética desembocando, por fundido encadenado, en un tercer plano con acción, atravesado desde su lado superior derecho al lado inferior izquierdo por un grupo de personas en procesión -principalmente mujeres, unos pocos hombres y algunos asnos (fig. 7).

El flujo de estas tres imágenes presupone cierto racord y establece la localización de la acción de Sierra maldita. Se trata de un espacio de carácter áspero que revertirá, narrativamente, en un trato virulento hacia las mujeres que lo habitan. El tema musical inicial termina en crescendo y desaparece el texto escrito. Una voz masculina extradiegética inicia el relato de un romance ${ }^{508}$ mientras un segundo tema musical -con base de tamboresrefuerza el sentido trágico de los hechos que describe el narrador, mientras la cámara se fija en dos mujeres a las que sigue en un movimiento de panorámica (fig.8).

\footnotetext{
508 "Cuenta el romance que las mujeres de un pueblo andaluz y moruno contemplan cada día temblorosas un picacho entre la bruma, la Niña Negra. Un hombre desgració a una mujer entre sus riscos y la dejó abandonada a su ventura. Los lobos dieron fin a la tragedia. Puebla de Arriba fue desde entonces maldita como su sierva. Sus pastos y sus tierras se secaron y las mujeres allí nacidas ya no alumbraron un nuevo ser. Los hombres, con la superstición a cuestas y despreciando las entrañas yermas, iban al valle a buscar esposas. Un año tras otro las hembras malditas de Puebla de Arriba bajan a la Virgen de Puebla del Valle a implorar la dicha del dolor de madre, son las cobijadas. Cobijadas por herencia moruna en un pañuelo negro que casi les tapa la cara para que por sus ojos escape la leyenda maldita. Bajan temblando por la sierpe empinada y sin atreverse a mirar al pueblo fecundo que les roba entre los gritos de su feria los pensamientos de unos mozos vencidos por el fatalismo. Porque Puebla del Valle es una gran guitarra donde la mano del destino lleva tocando una copla alegre durante siglos y siglos".
} 


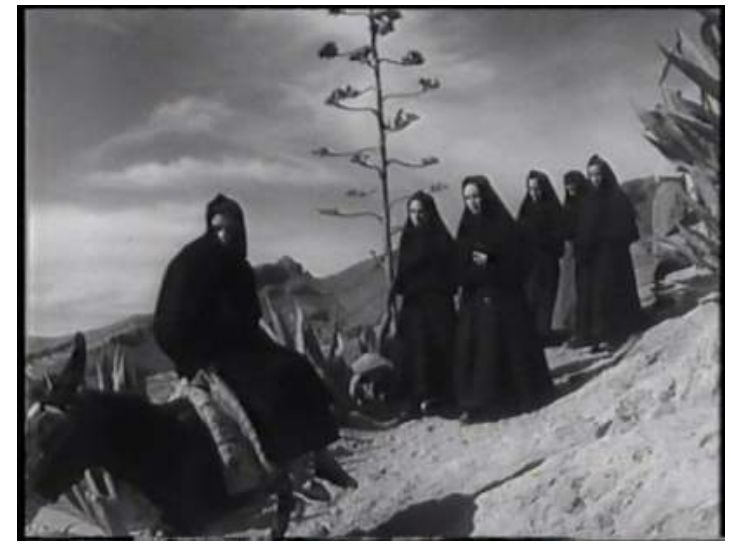

Figura 7

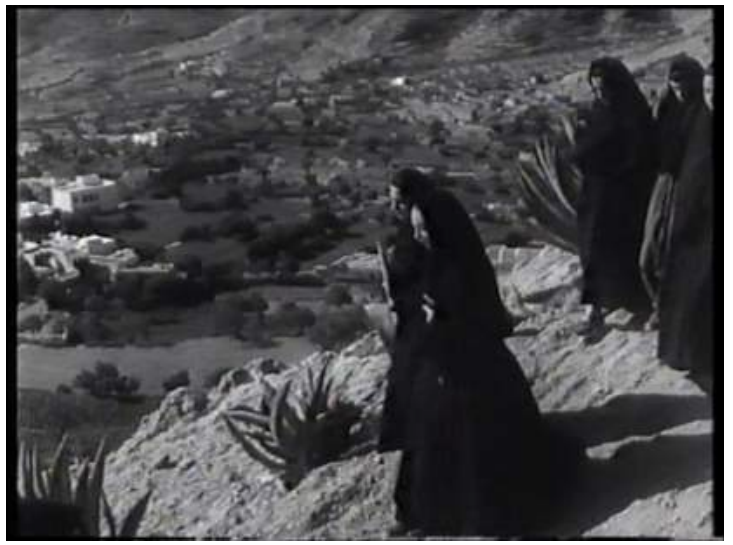

Figura 8

La uniformidad de sus largos ropajes negros y su semblante bajo, además de la amplitud de encuadre, impiden distinguir el rostro de ninguna de ellas. No obstante, atendiendo al relato del narrador se identifican como las "cobijadas", las mujeres anónimas y repudiadas de Puebla de Arriba dirigiéndose a Puebla del Valle. Se trata de una puesta en escena que estética y discursivamente presenta al grupo de mujeres como un todo homogéneo, sin rasgos específicos individuales. Además, esta secuencia inicial fue concebida desde los preceptos del material literario, subrayado con el uso del narrador como recurso al que se subordinan el resto de componentes. Por este motivo las dos primeras imágenes fijas funcionan esencialmente como "setting: the space of story and event ${ }^{509}$ ", como recuerda Lefebvre. También la música extradiegética sirve al sentido bucólico del relato y la presencia humana responde a la necesidad por identificar, a grandes rasgos, a las protagonistas del romance.

Resulta interesante constatar como todos los textos coetáneos al filme son posteriores al fallo del jurado de la primera edición del Festival de San Sebastián donde obtuvo el galardón a mejor película ${ }^{510}$. A diferencia de publicaciones sobre las películas de Mur Oti y de Orduña, las referidas al filme de del Amo solo se han encontrado en Radiocinema. Las escasas referencias al tratamiento del paisaje no trascienden las descripciones de

\footnotetext{
${ }^{509}$ Lefebvre, 2006: 21. En cine "cada unidad de significado implica un escenario". Traducción de la autora.

${ }^{510}$ Concha de Oro en la primera edición del Festival Internacional de Cine de San Sebastián de 1954.
} 
cariz poético. Un ejemplo es el fragmento siguiente, "Regio y vigoroso paisaje que enmarca el pueblo almeriense de Mojácar ${ }^{511 " . ~ C o n ~ l a ~ e x c e p c i o ́ n ~ d e l ~}$ apunte del número 229 en que se reconoce el paisaje como elemento fundamental "tanto como las personas".

La elección de la forma de fábula y el recurso a la voz en off fueron tema de debate en las páginas de Objetivo. Eduardo Ducay advertía que "mientras consideremos esa superstición como una fuente de belleza, serviremos al romanticismo y al tópico". Para el crítico las gentes de Mojácar eran una visión estereotipada de la Andalucía "trágica, fuerte, supersticiosa y legendaria ${ }^{512 ", ~ a u n q u e ~ e s t a ~ n o ~ f u e s e ~ l a ~ r e p r e s e n t a c i o ́ n ~ h a b i t u a l . ~ U n a ~ v e z ~ m a ́ s ~}$ el legado lorquiano venía a justificar la representación de los tipos andaluces, a lo que Ducay en la misma línea en que se refería a Condenados, opinaba que "al imitar a Lorca, se toma la envoltura, la cáscara, y lo que hay dentro todo un mundo poético- queda $\sin$ tocar $^{513}$ " en referencia a la dimensión social de Sierra maldita.

Las secuencias de arranque de Condenados y Sierra maldita van dirigidas a desarrollar sendas temáticas propias del drama rural sustentadas en los factores elementales enumerados por Requena en la definición de este género. Entre los que destaca "la presencia de un código moral y de costumbres rígido e inflexible cuya violación es acusada socialmente como la transgresión de un tabú que amenaza al conjunto social". Esto es, la existencia de un código referido a un tabú -en sendos casos sexual-, su transgresión y la pública de esta ${ }^{514}$. Unos factores que en el ámbito rural "presuponen núcleos [...] pequeños e intensamente interconectados cuya identidad depende esencialmente de su código fundador" tal como se ha tratado en la definición sociológica de estas comunidades. El agente transgresor en Condenados y Sierra maldita es el arquetipo femenino protagonista poseedor de una exuberante belleza física -incluso abiertamente sexualizada- como constata la elección de la actriz Lina Rosales en el papel

${ }^{511}$ Radiocinema. Núm. 237. Febrero de 1955.

512 Objetivo. Núm. 5. Mayo de 1955.

513 Ibídem.

${ }^{514}$ Aguilar, 1988: 17. 
de Cruz en Sierra maldita. Este personaje, como también sucede con la Aurelia de Condenados, condensa en su fisicidad los anhelos y frustraciones de una sociedad atávica fundamentada en las supersticiones. En otras palabras, los personajes femeninos son receptáculo del odio -otro de los elementos constitutivos del género del drama rural- generado en los núcleos sociales que habitan. Y también del odio derivado de las condiciones hostiles del propio terruño del que reciben el maltrato en forma de infertilidad y desprotección como es el caso de Cruz pero también de La Novia de Bodas de Sangre o la protagonista de Yerma de Federico García Lorca.

\subsection{Cañas y barro, 1954, el paisaje valenciano}

El último caso que constituye la tríada de arquetipos femeninos rurales concebidos estética y conceptualmente a partir del vínculo ontológico con la tierra es Nela, la protagonista de Cañas y barro la obra literaria de Blasco Ibáñez llevada al cine por Juan de Orduña en 1954. Cañas y barro cuenta la historia de Nela y Tonet, dos niños de El Palmar, pueblo de la Albufera de Valencia, a finales del siglo XIX. Desde temprana edad los dos protagonistas establecen una relación sentimental marcada por las vicisitudes de su comunidad. La falta de expectativas lleva a Tonet a alistarse voluntario en la Guerra de Cuba y a Nela a casarse con Cañamel, el hombre más acaudalado de la aldea. Para cuando Tonet vuelve de la guerra decidido a triunfar profesional y sentimentalmente Nela ya es una mujer casada. Amparados por los arrozales de la Albufera, los dos protagonistas se convierten en amantes perseguidos por Jaime, el sobrino desheredado de Cañamel, quien temeroso ha incluido en su testamento una clausula por la que Nela quedaría despojada de su herencia en caso de iniciar una nueva relación sentimental. A pesar de todo Nela dará a luz a un niño fruto de su amor con Tonet, obligado a deshacerse del recién nacido. Pero será descubierto por Jaime durante una disputa que se zanjará con la muerte del primero. 
El final de los protagonistas de Cañas y barro sitúa la obra en un registro dramático muy concreto. Mas, a diferencia de los otros dos casos fílmicos aquí tratados, la obra de Blasco Ibáñez y Orduña presenta un contexto social rico en tipos y descripciones del entorno rural valenciano. Una voluntad observacional y descriptiva que valió a Blasco lbáñez convertirse en uno de los máximos exponentes de la vertiente literaria del naturalismo de finales del siglo XIX y principios del XX. Su tetralogía costumbrista formada por Arroz y tartana,1894, La barraca, 1898, Entre naranjos, 1900, y Cañas y barro ${ }^{515}$ se lee como un "documento apasionante de la época y del paisaje valencianos" ${ }^{516}$. En esta línea la crítica especializada, y demás textos promocionales interpretaron la versión de Orduña. En Primer Plano, los límites del realismo como "género, estilo y modo español" enlazan Cañas y barro con la obra de Menéndez Pelayo ${ }^{517}$ dando por sentada la conjunción entre localismo y realismo. De este modo, "la Albufera y las costumbres de sus gentes dan un espléndido tipismo y un realismo fuerte a 'Cañas y barro'”518. En otro texto del mismo año publicado en Radiocinema se lee "Cañas, agua y barro en fuerte explosión de realidades ${ }^{519 ", ~ e n ~ u n ~ i n t e n t o ~ p o r ~}$ encontrar en los materiales más primitivos la esencia del pueblo español. El empeño por abrazar el regionalismo valenciano en ocasiones alcanzó un tono celebrativo como sucede en el texto de Radiocinema: "He aquí la película de la luminosidad levantina. Cañas y barro..., arrozales..., naranjales..., barracas... y el pato y la barca..., el junco en la Albufera y la tartana en el camino... ${ }^{520 "}$.

De hecho siguiendo los preceptos característicos de la obra de Blasco Ibáñez, de Orduña también entendía el naturalismo como sinónimo de autenticidad, no en vano el realizador pretendía convertir Cañas y barro en

\footnotetext{
${ }^{515}$ Cabe tener en cuenta que el primigenio regionalismo de Blasco Ibáñez, basado en la minuciosa descripción del entorno rural valenciano y sus habitantes, llegó a ser entendido a niveles universales como demuestra el gran número de adaptaciones cinematográficas del Hollywood de la época.

${ }^{516}$ Ramón Samaniego “El paisaje valenciano en 'Cañas y barro”' en Primer Plano. Núm. 730.10 de octubre de 1954. Año XIV.

517 lbídem.

${ }^{518}$ Primer Plano. Núm. 711. 30 de mayo de 1954. Año XIX.

${ }^{519}$ Radiocinema. Núm. 203. Junio de 1954.

${ }^{520}$ Radiocinema. Núm. 215. Septiembre de 1954.
} 
paradigma de lo que debía ser la corriente realista en el contexto cinematográfico español, y en concreto lo que calificaba como 'realismo poético', superación del 'realismo clásico' y en concreto "social, la angustia humana ${ }^{521 "}$ presente en las entrañas de la tierra valenciana.

Siguiendo los preceptos formales del cine clásico, Cañas y barro arranca de un fundido negro seguido de los títulos de crédito compuestos de letras blancas sobre un fondo natural nocturno. Se abre con un plano general del paisaje en el que la línea del horizonte converge con la zona húmeda inferior.

En primer plano unas cañas agitadas por el viento, que también remueve las aguas, confieren movimiento (fig.9a). Mediante un fundido encadenado se enlaza con otra vista, de características similares a la anterior, ahora interrumpida por la presencia de una pequeña embarcación de vela (fig.9b).

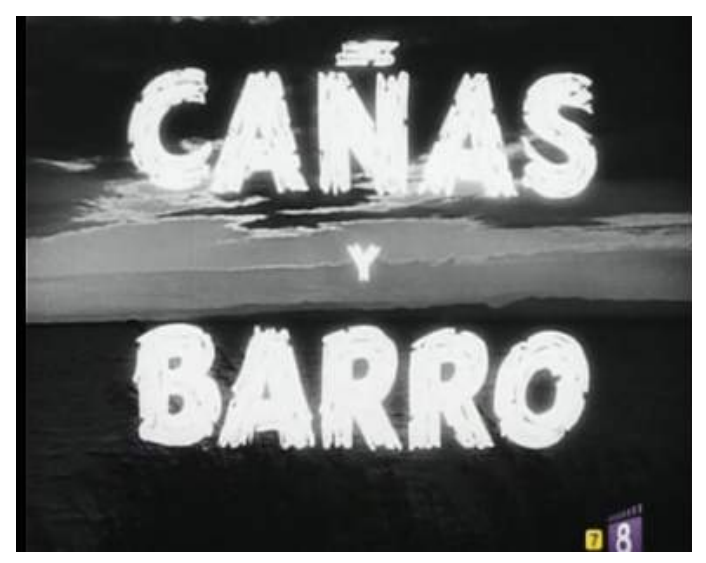

Figura 9a

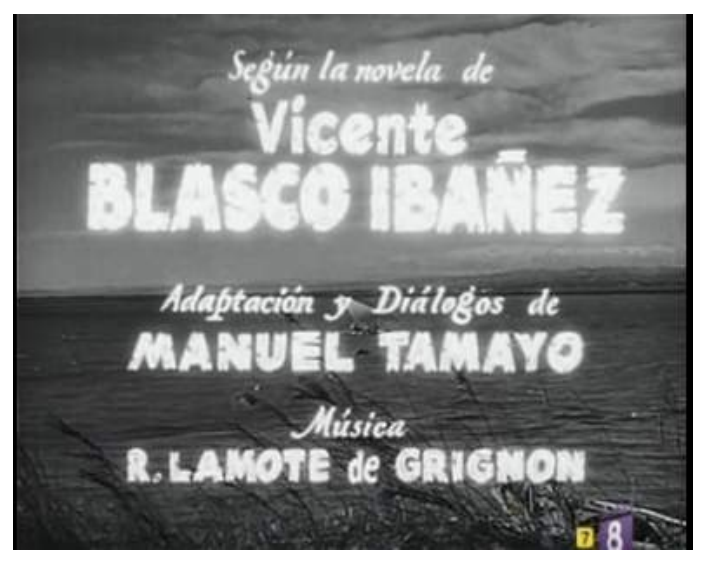

Figura 9b

La barca entra en escena justo cuando la melodía orquestal ejecuta un segundo tema de tiempo más calmado que el primero. Este, de ritmo ágil, enfatiza el sentido dramático del relato que va a desarrollarse. Mientras prosiguen los créditos la cámara ofrece una panorámica de la Albufera valenciana siguiendo a la embarcación. Este dispositivo se repetirá en la siguiente escena hasta concluir los títulos de créditos y la música extradiegética que los acompaña. Comienza un nuevo leitmotiv orquestal

521 Ibídem. 
mientras la barca se dirige a la orilla de un arrozal. La cámara espera su llegada, dos niños y una niña toman tierra. Se trata de Nela, Tonet y Jaime (fig.10). La música decrece para oír el diálogo de los tres personajes y también los sonidos del espacio natural.

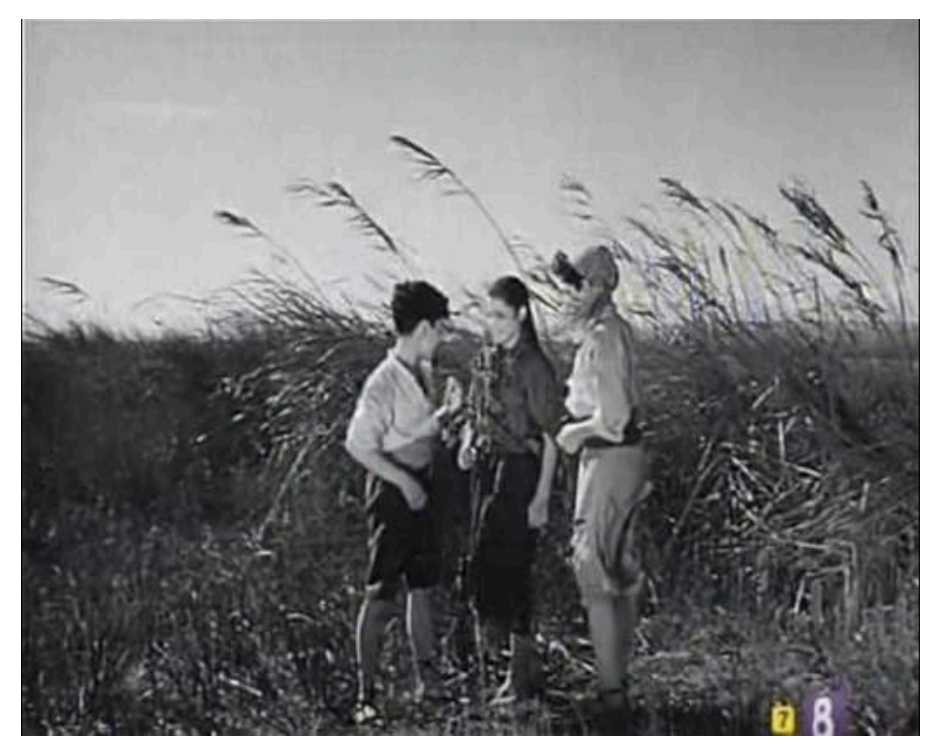

Figura 10

Juan de Orduña, leal a la tradición naturalista de Blasco Ibáñez, concibió un entorno rural basado fundamentalmente en la presencia continua de movimiento como sinónimo de vida. Movimiento creado a partir de los elementos del espacio, de la acción de los personajes y también del dispositivo fílmico. Pues el giro de cámara utilizado revela la voluntad por registrar la amplitud del paisaje de la Albufera de Valencia. Si bien es cierto, la elección de este enclave resultó un imperativo al adaptar esta obra en cuestión. En conclusión la puesta en escena de la secuencia de arranque de Cañas y barro define el peso discursivo que el paisaje tendrá en la narración filmica.

Del recorrido por los tres títulos analizados se deduce un juego de equilibrios entre los dos agentes constitutivos de los respectivos paisajes: el espacio y los arquetipos que lo pueblan. Del dominio del personaje sobre el espacio de Condenados, a la subordinación de este a los condicionantes del entorno en Sierra maldita y finalmente el equilibrio de ambos agentes en 
Cañas y barro que dará lugar a un retrato social de la Valencia rural finisecular.

\subsection{Análisis comparado de los arquetipos femeninos rurales}

Los arquetipos femeninos de Condenados, Sierra maldita y Cañas y barro constituyen una herramienta para entender las estrategias de representación del paisaje rural en el cine español de los 50. El análisis comparado de este elemento semántico revela una dimensión significante que discurre entre cuestiones estéticas que remiten a la tradición paisajística y lecturas de género como las aplicadas por Carmen Arocena en sus trabajos sobre este tipo de películas.

En la filmografía de Manuel Mur Oti se localiza un nutrido corpus de arquetipos femeninos de entre los cuales la protagonista de Condenados constituye el paradigma del vínculo ontológico mujer-tierra. Aurelia es la protagonista absoluta del relato, así lo anuncia a nivel formal la secuencia de arranque y lo corrobora el desarrollo narrativo en que el personaje goza de presencia "en la mayor parte de los encuadres y en los pocos donde su imagen falta, su ausencia se recubre con los diálogos donde los personajes masculinos hablan de ella o con metáforas visuales que la convierten en algo omnipresente ${ }^{522 " . ~ A r o c e n a ~ l a ~ d e f i n e ~ c o m o ~ u n a ~ ' p r e s e n c i a ~ o b s e s i v a ' ~ a l ~ e s t a r ~}$ concebida desde la perspectiva masculina que la reduce a "significante en el que se ancla el deseo masculino [...] portadora del deseo del Otro ${ }^{523}$ ". En primer lugar, Aurelia es la única mujer con presencia en la versión cinematográfica, no así en la obra teatral ${ }^{524}$ como se ha explicado

\footnotetext{
${ }^{522}$ Arocena, 2010: 11.

523 Ídem: 12.

524 José Suárez Carreño concibió un corpus con un número significativo de personajes femeninos entre los que destaca la tía Teresa, que cumple una función maternal para con la Aurelia, además de Dolores, antigua novia de José y que profesa estima hacia el matrimonio protagonista, la madre de Matías y cuatro vecinas. Lo que se traduce en un $47 \%$ de cuota femenina del total de 17 personajes enumerados en el libreto de la obra teatral, de entre los cuales seis personajes masculinos tienen un protagonismo significativo frente a los cuatro femeninos, lo que se traduce en unas cuotas del $35 \%$ y del $23 \%$, respectivamente.
} 
anteriormente. El resto del reparto lo completan los vecinos del pueblo, además de José y Juan. Los primeros temen las consecuencias de trabajar las tierras de Aurelia, y también José recela de Juan, el único que, desconocedor del crimen de sangre acontecido, osa ocuparse de la finca en ausencia del marido. En definitiva, un temor latente entre el grupo masculino que converge en el mismo eje, Aurelia. Sin embargo, a tenor de la narración, el personaje de Aurora Bautista es una mujer abnegada y leal al compromiso matrimonial, que trabaja las tierras sin obtener fruto alguno. Unas circunstancias que diegéticamente se concretan en los dos únicos menesteres de la mujer: el cuidado de las tierras y de su matrimonio. Tal es la supeditación de la mujer a estos dos cometidos que carece de voluntad propia y por tanto nunca es un sujeto de acción, en los términos empleados por Carmen Arocena. Aurelia es el objeto de deseo -y por tanto agente pasivo- de Juan y de José y, del choque de intereses entre estos dos estallará la tragedia. La cual, además, ha sido anticipada por los hechos del pasado, lo que justifica el recelo de los hombres del pueblo ante la posibilidad de repetirse.

El hecho que Aurelia no llegue a constituirse en sujeto de acción y permanezca como objeto pasivo resulta trascendental en el punto de esta argumentación puesto que las trágicas consecuencias que de ella dimanan responden única y exclusivamente a los anhelos y acciones infundidos por los personajes masculinos. Unas circunstancias que se concretan en la cuestión de 'la mirada' definida por Carmen Arocena. En la versión fílmica -en la teatral Suárez Carreño cuenta sobre un pasado en que Aurelia y Matías, el asesinado, fueron novios- el conflicto dramático viene dado por las miradas dirigidas sobre Aurelia y que José gestiona en clave posesiva.

Narrativamente, Condenados se divide en dos partes. Una primera protagonizada por Aurelia y Juan trabajando las tierras y obteniendo recompensa a su dedicación en forma de fruto y de satisfacción de ella como dueña. $Y$ una segunda parte que arranca con la llegada anticipada de José dando inicio a una batalla entre los dos hombres con el único fin de reafirmar su virilidad ante Aurelia. Es en este momento donde la concepción del 
arquetipo femenino queda subrayada discursivamente en los términos descritos de subordinación al orden patriarcal de esta comunidad rural. Un hecho constatable, primeramente, en el empeño de Aurelia por entregarse al matrimonio en los términos de la buena esposa que ha esperado abnegadamente la vuelta del marido y ha trabajado diligentemente las tierras de su propiedad. Sin embargo, el crimen del pasado ha creado un trauma en José que condicionará su comportamiento desde la primera escena en que el matrimonio se reencuentra y de que da muestra el diálogo que a continuación se reproduce.

- ¿No duermes?

- No

- ¿Que hacías?

- Mirarte.

- Ahora debes dormir. Tiempo te queda para mirarme.

- No.

- Y para cansarte de mirarme.

- No digas eso. Tu no sabes lo que es vivir entre aquellas paredes soñando solo con esto, con mirarte así. $Y$ lo que es peor, saber que otros podían verte.

La acción de mirar, y precisamente a Aurelia, es el desencadenante del deseo y de la tragedia ya que, como argumenta Carmen Arocena "la tragedia de Condenados estalla cuando las dos miradas masculinas, la de José y de Juan confluyen sobre el mismo objeto ${ }^{525 " . ~ E l ~ n i v e l ~ d e ~ o b c e c a m i e n t o ~ d e l ~}$ marido ante la posibilidad que Aurelia sea mirada por otros queda manifiesto en las palabras con que concluye la conversación.

- Olvida todo eso.

- Ya sé, ya sé que tengo que olvidar pero no puedo tan pronto. Me habían dicho que tenía que estar allí dentro veinte años, he vivido seis pensando que tendrían que pasar catorce más para volver a casa. Me he pasado los días y las noches echando encima de tu cara los catorce años de mi condena para envejecerte, para imaginarte como serías cuando nos encontráramos y de pronto se abren las puertas de la cárcel y me dicen que vuelva a casa, y llego y veo que estás más

${ }^{525}$ Arocena, 2010: 12. 
hermosa que nunca. Aún más hermosa que cuando me llevaron de aquí.

- ¿Lo sientes?

- No lo sé.

- Descansa, descansa y piensa que tienes que estar alegre. Ya has vuelto, eso es lo que importa.

Formalmente este diálogo constituye el reencuentro del matrimonio, precisamente, sobre la cama conyugal. El sentido íntimo de la escena se conforma a partir de tres encuadres cerrados, el primero de ellos es un primer plano de la protagonista recostada mientras es mirada por el marido que habla desde el fuera de campo. El hecho que la cámara se mantenga sobre el rostro de la mujer durante los instantes iniciales de la conversación, atendiendo al tema de la misma, establece la concepción de Aurelia como objeto mirado. De hecho un travelling acompaña el movimiento de la protagonista que se incorpora para adoptar un gesto complaciente hacia su marido mientras este confiesa el suplicio vivido durante su encarcelamiento. Por corte seco la cámara se desplaza del lado de José, quedando este casi de espaldas y Aurelia enmarcada de frente manteniéndose atenta al marido (fig.11a). El hecho de que el plano no muestre a José mientras habla le confiere a este una función narradora -de voz over- revirtiendo sobre el personaje, visible, de Aurelia las causas y consecuencias del trauma descrito. Finalmente un nuevo encuadre, ligeramente del lado de Aurelia, enmarca a José mirando con gesto irritado a su compañera (fig.11b).

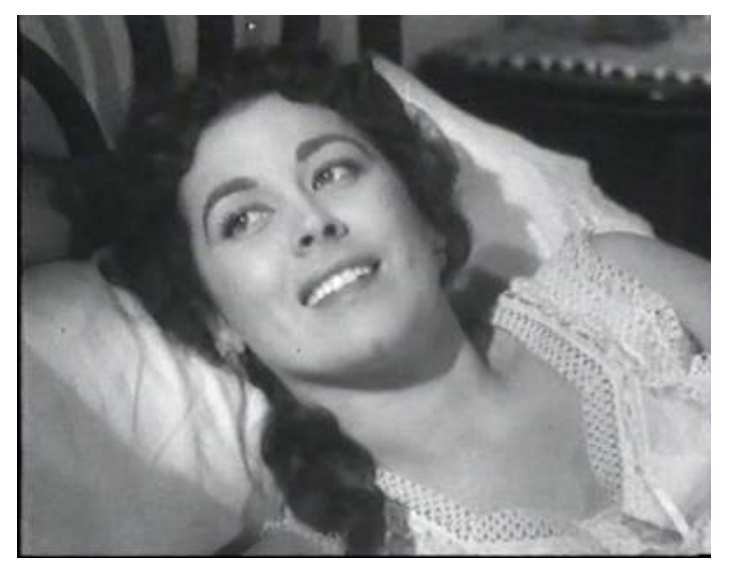

Figura 11a

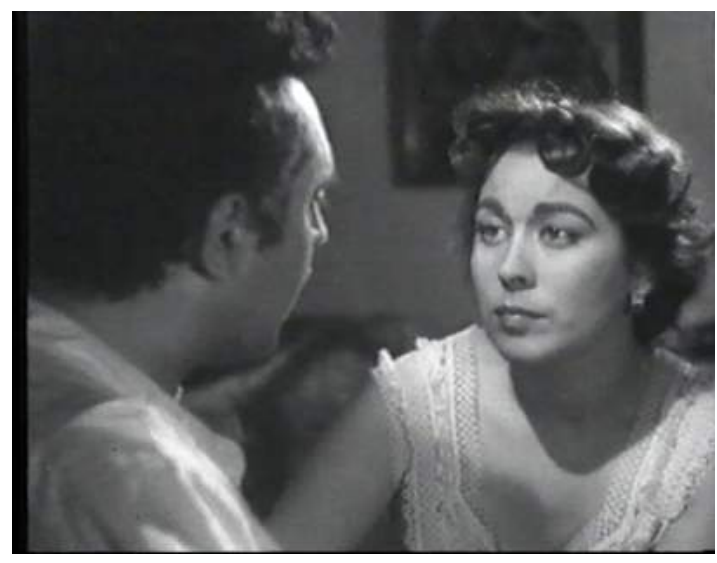

Figura 11b 
Formal y discursivamente esta secuencia de reencuentro conyugal reafirma el tratamiento del personaje femenino a lo largo del trayecto narrativo de Condenados. Aurelia ha sido la causa del crimen cometido por José, y ahora es el objeto de la mirada -y con ello de deseo, aunque aun silencioso- de Juan, además del ente temido por el resto de hombres. Sin embargo Aurelia, como ocurre en esta secuencia, se mantiene apacible y sumisa, creyéndose libre de toda culpa. Pero más allá de los hechos narrados, el personaje de Aurelia ha sido concebido cargando la culpa primera que Arocena relaciona con la hamartia que Aristóteles explicaba en su Poética. Su delito es ser el objeto de la mirada de otro hombre, de ahí que el marido insista en hacerla responsable de su crimen. Aurelia se enfrenta a esta carga impuesta en la escena en que confronta al grupo de vecinos ante su pasividad por no ayudarla a labrar las tierras ${ }^{526}$. En ella se muestra la valentía de la mujer a la vez que certifica su subordinación al orden patriarcal de la comunidad. No en vano tal y como expresa Juan nada más llegar a la finca: "hay tres cosas que un hombre que lo sea no abandona jamás, la escopeta, el caballo y la mujer". Un subrayado verbal que corrobora la hipótesis de considerar a Aurelia al mismo nivel que el resto de propiedades del hombre, su dueño y señor. Una premisa asimilada por la propia mujer y que condicionará su actitud a lo largo del trayecto narrativo, de ahí que la culpa primera de que habla Arocena no pueda encontrarse en sus actos sino en su condición femenina.

El personaje de Aurelia fue encarnado por Aurora Bautista (1925-2012) cuya irrupción en la industria cinematográfica de la época con tres papeles protagonistas en películas de Juan de Orduña ${ }^{527}$ le reportaron reputación como actriz de gran temperamento interpretativo. La relevancia de Bautista en la industria de aquellos años tuvo su reflejo en la campaña promocional de

\footnotetext{
${ }^{526}$ Justificándose los vecinos por haber advertido a Juan, Aurelia lleva a cabo el siguiente alegato: “¿Qué le habéis dicho? [...]. ¿Que José está en presidio? ¿Que mató a un hombre? ¿Que esta casa desde entonces es la casa del condenado, y que vosotros preferís que se caiga piedra a piedra antes que un solo brazo me ayude a levantarla? [...] Le habéis dicho que José puede volver algún día y que si mató a un hombre por el solo delito de mirarme con más razón le mataría a él que vivió en mi casa y labró mis tierras para impedir que yo muriera. Y que en el pueblo no queréis más sangre".

${ }^{527}$ Locura de amor, 1948, Pequeñeces y Agustina de Aragón, ambas de 1950.
} 
Condenados como muestran los títulos de artículos tales como "Condenados. Un drama sensacional, con al sensacional reaparición de la gran estrella Aurora Bautista" o "Condenados es una tragedia de celos con la que reaparece Aurora Bautista" además del protagonismo absoluto en la cartelería. Material que corrobora la centralidad del personaje de Aurelia y por extensión de la actriz Aurora Bautista en Condenados.

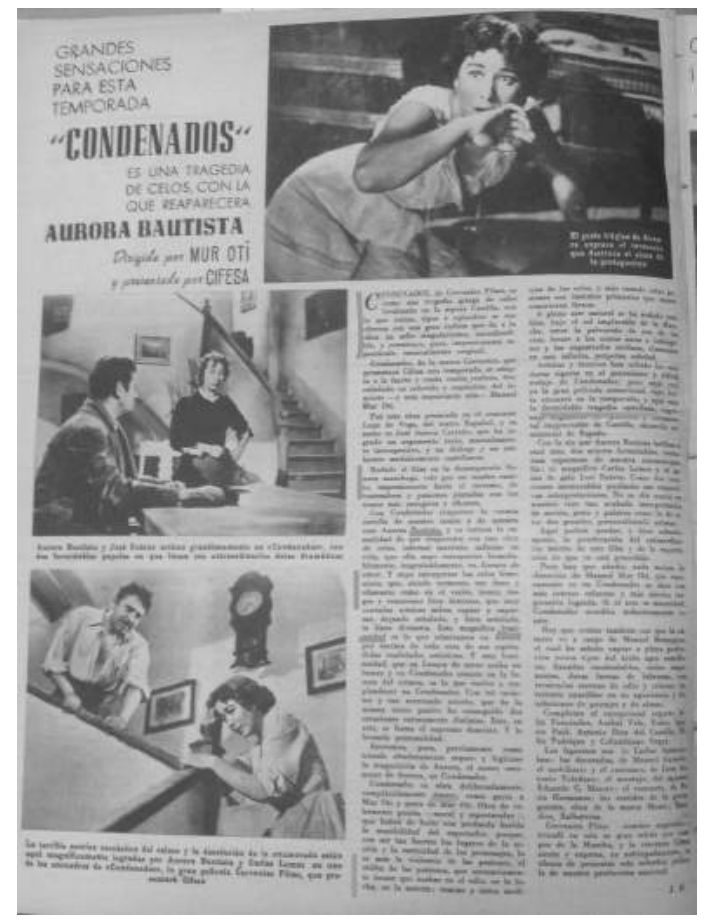

Primer Plano. 5 de julio de 1953. Año XIII, núm. 664

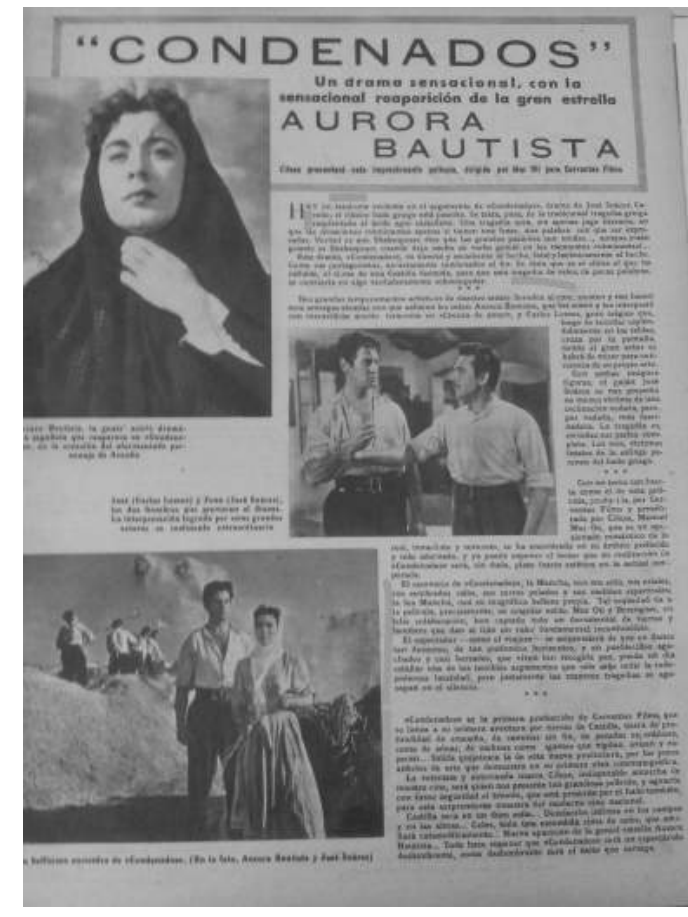

Primer Plano. 6 de septiembre de 1953. Año XIII, núm. 673.

La elección de Lina Rosales para interpretar al personaje de Cruz en Sierra maldita responde a imperativos estéticos, una hipótesis fundamentada en el trabajo sobre el rostro de la actriz. Sintomático al respecto es la presentación del personaje a partir de tres primerísimos planos (fig.12a, b y c). Una escena que, por otra parte, tiene lugar en el interior de una pequeña parroquia a la que el grupo de las cobijadas asiste al ritual de un bautizo. Se trata de una escena de fuerte carga simbólica teniendo en cuenta el origen de la estigmatización social del grupo de mujeres al que pertenece Cruz. 


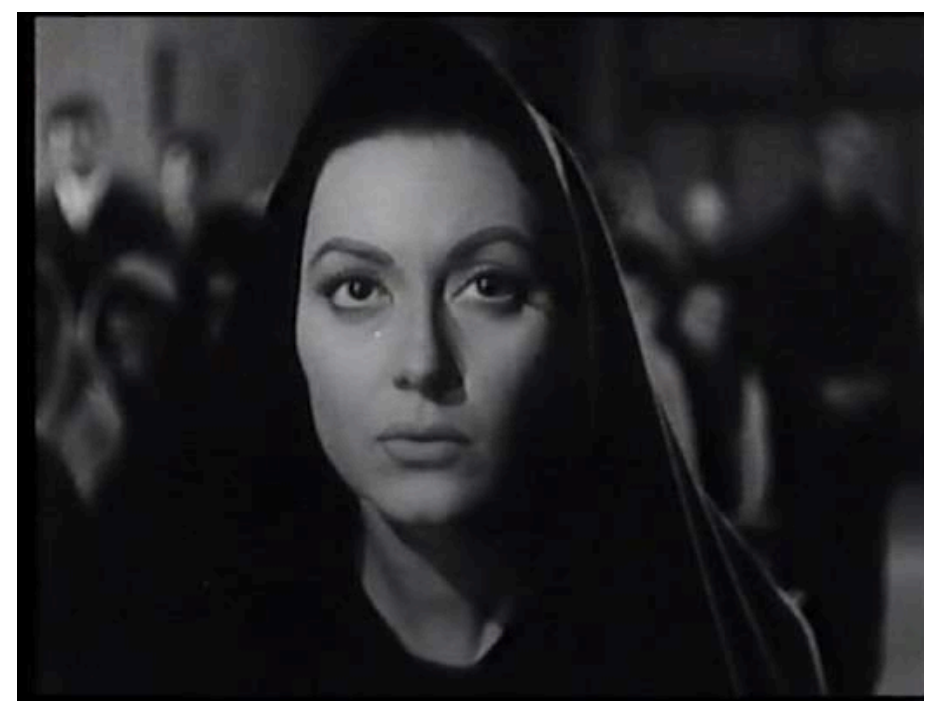

Figura 12a

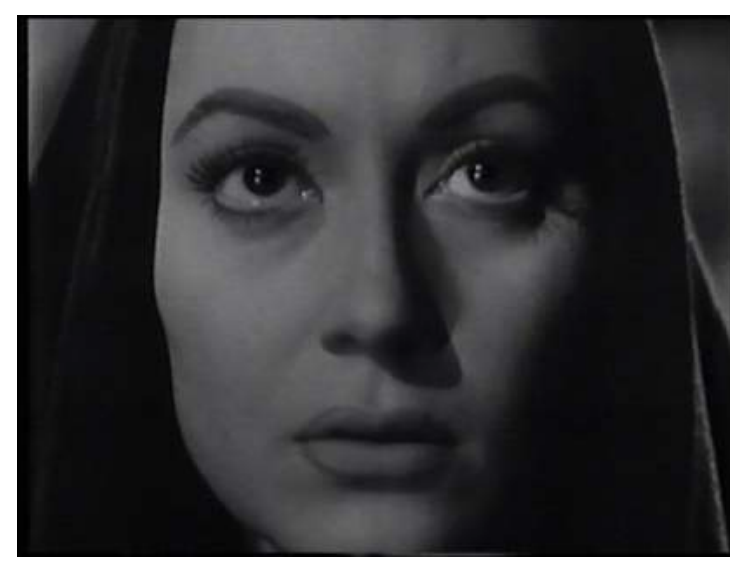

Figura 12b

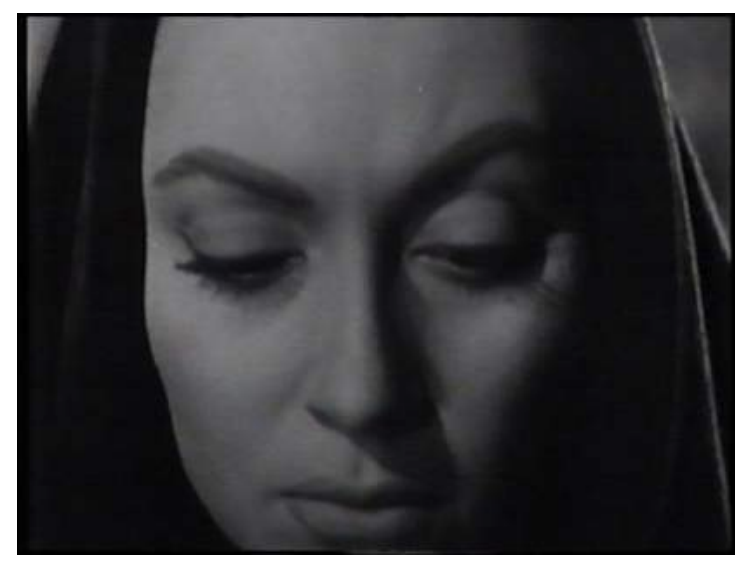

Figura 12c

La escena anterior a la presentación de Cruz mostraba el ambiente festivo de Puebla del Valle con sus vecinos en las casetas de feria y el repicar de las campanas. Un palmeo da entrada a un nuevo tema melódico con base de guitarra que marca un cambio de actitud entre los allí presentes. Un montaje rápido encadena tres planos de diferentes grupos dirigiendo su mirada hacia un mismo punto, un plano general muestra el grupo de las cobijadas avanzando en procesión (fig.13). La sucesión de una serie de planos de miradas dirigidas al grupo acrecienta el sentimiento de extrañeza al no existir el contraplano de la mirada de las cobijadas (fig.14). Es más, estás se apresuran a entrar en el templo con actitud afable y mirada huidiza. Una 
escena construida formalmente y remarcada estéticamente a partir del contraste de colores de las vestimentas de los dos grupos, uno de blanco y el otro de negro.

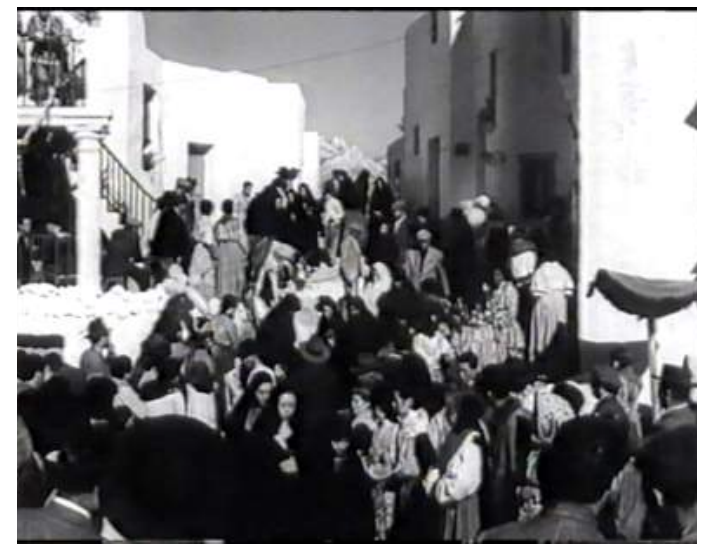

Figura 13

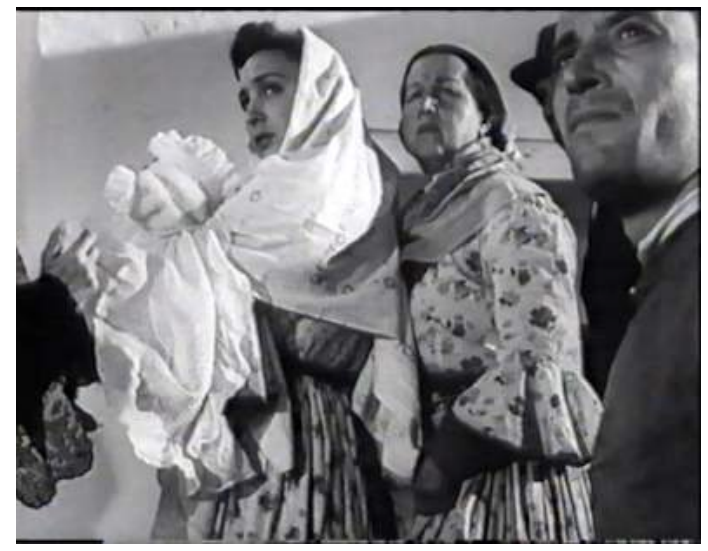

Figura 14

Ya en el interior del templo, la división entre sujetos que miran y los que son mirados se concentra en el personaje de Cruz. Primero la madre del niño que va a ser bautizado que mira abruptamente (fig.15a). Y después es Juan quien lanza una serie de miradas con gesto de fascinación hacia Cruz (fig.15b).
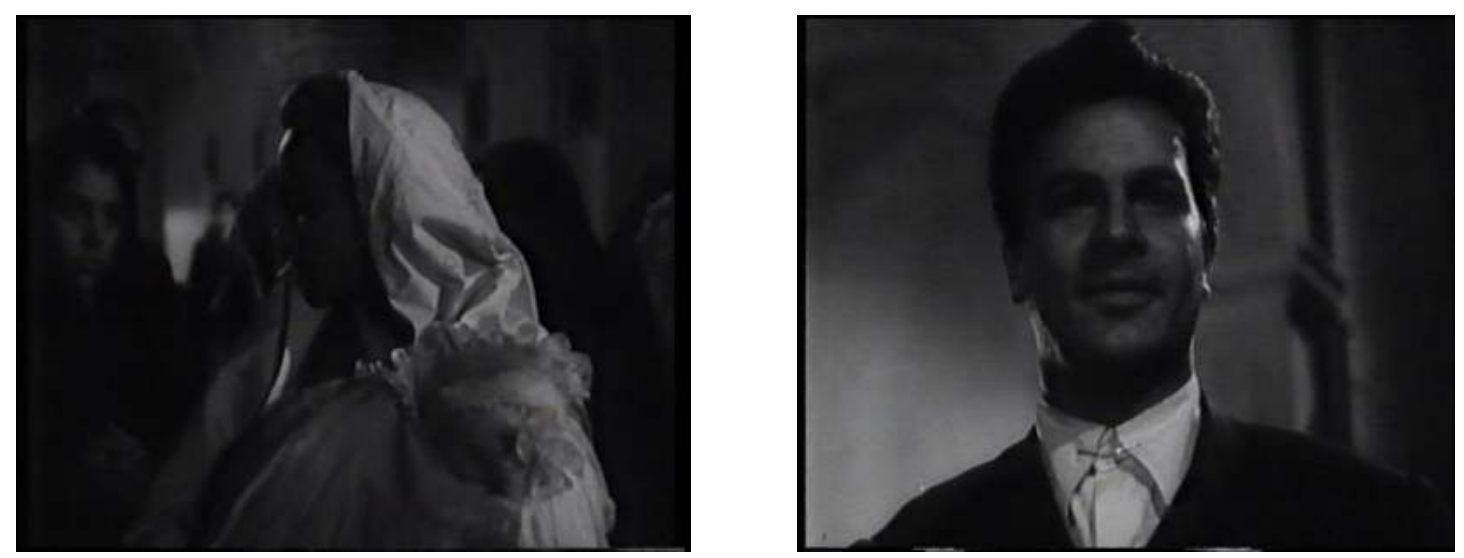

Figur|ilgtrea 15b

El plano-contraplano que habitualmente construir este juego de miradas en este caso no existe porque Cruz dirige la vista hacia la imagen de la virgen que preside el templo. Los gestos que acompañan las miradas de la madre y 
de Juan diferencian entre una mirada de temor y una mirada de ensimismamiento sobre el mismo objeto: Cruz, quien dirige su mirada hacia un cuarto elemento. El hecho que Cruz no devuelva la mirada a ninguno de estos sujetos incurre en la teoría que Arocena y Zubiaur aplicaban al arquetipo femenino de Condenados, materializando en ambos casos "la pérdida de voluntad del personaje arrebatándole la mirada ${ }^{528 " . ~ A ~ p a r t i r ~ d e ~}$ este momento el trayecto narrativo aboca a Cruz a una carrera por proteger su integridad de la rabia del resto de mujeres que no conciben la felicidad de las más jóvenes, y sobre todo del deseo sexual de ciertos carboneros que llega a traducirse en ataque físico.

El punto álgido del desarrollo narrativo de Sierra maldita se produce en la escena en que, ante el empecinamiento de Juan por bajar al pueblo, Cruz se queda a la merced de los carboneros que ya han depositado en ella su mirada habiéndola asaltado uno de ellos. Esta escena, que tiene lugar trascurridas dos terceras partes del metraje, recoge un momento de fatiga física y desaliento mental de los hombres de la cuadrilla, un nivel de extenuación que acaba de cobrarse la primera víctima. Jacinto, uno de los carboneros, ha huido a la cumbre de la Niña Negra en un estado de enajenación mental que concluye con su suicidio. Aunque narrativamente su muerte se justifica por el estado general de fatiga sumado a la afición a la bebida del personaje, diegéticamente se atribuye a Cruz. En una conversación entre un grupo de carboneros se dice, "Es una venganza de la Niña Negra. Todo esto nos lo trae una mujer que se ha reído de la maldición". Otro subraya, "Que es una venganza por tener aquí a esa mujer". A continuación la cámara enmarca el lugar donde se encuentra Cruz poniendo rostro y nombre al temor de los hombres (fig.16a y b).

${ }^{528}$ Zubiaur, 2013: 335. 


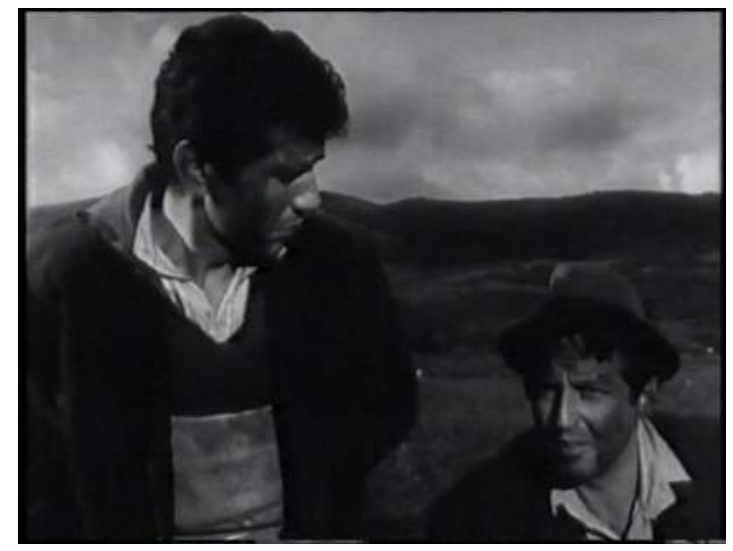

Figura 16a

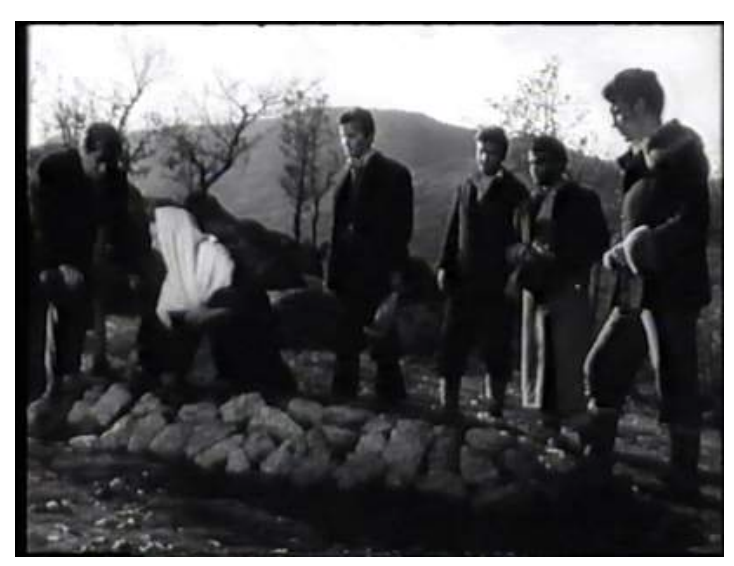

Figura 16b

Del mismo modo que sucediese en Condenados, el arquetipo femenino de Sierra maldita carga con una culpa primigenia que la hace ser temida por el resto de personajes masculinos y repudiada por los femeninos. Sin embargo, mientras en Condenados el factor temor poseía un explícito cariz sexual, en Sierra maldita el miedo adopta en un primer momento la forma de superstición, un tratamiento que, por otro lado, describe una sociedad rural anclada en un pensamiento irracional.

En la escena que sigue a la muerte de Jacinto el capataz de los carboneros subraya el ambiente enrarecido debido a la presencia de la mujer. Sugiere a Juan que se lleve a Cruz, pero este, confiado, no contempla tal posibilidad. Incluso Cruz suplica a su marido irse con él. Finalmente la mujer se queda sola a la merced de los carboneros, los cuales, con su mirada acechante, contribuyen a incrementar la tensión en el ambiente. Tras la partida de Juan, la rutina prosigue en el campamento invadido por el silencio, solo se escucha el sonido de la hacha de Lucas y un canto en forma de lamento de fondo. Los golpes de hacha marcan el ritmo de los pasos de Cruz, que impertérrita se desplaza por el lugar (fig.17a). Una vez más el habitual plano contraplano es sustituido por un juego de miradas unidireccional que muestra el objeto de la mirada de los sujetos masculinos, Cruz (fig.17b, c y d). 


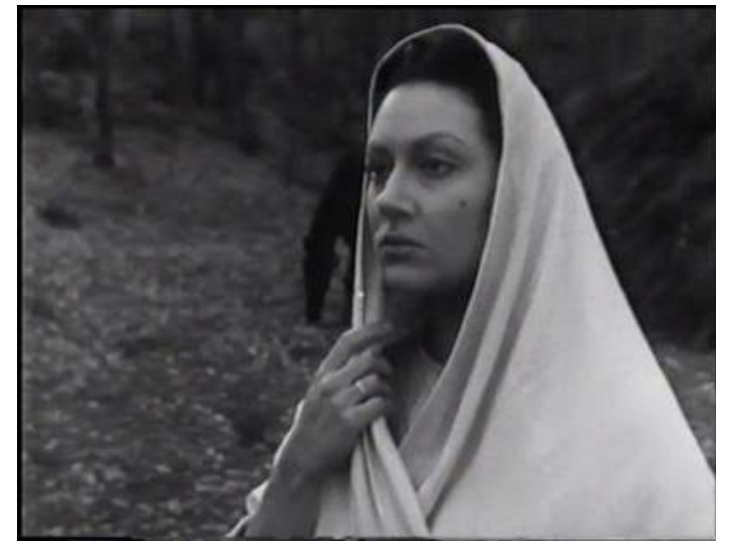

Figura 17a

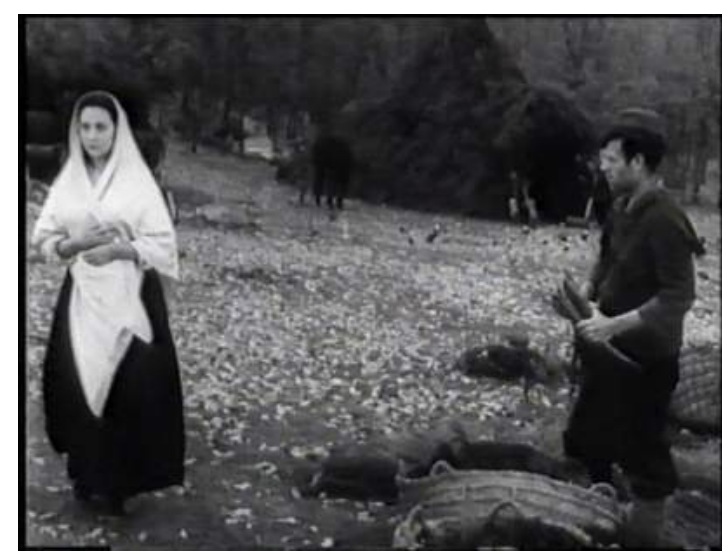

Figura 17c

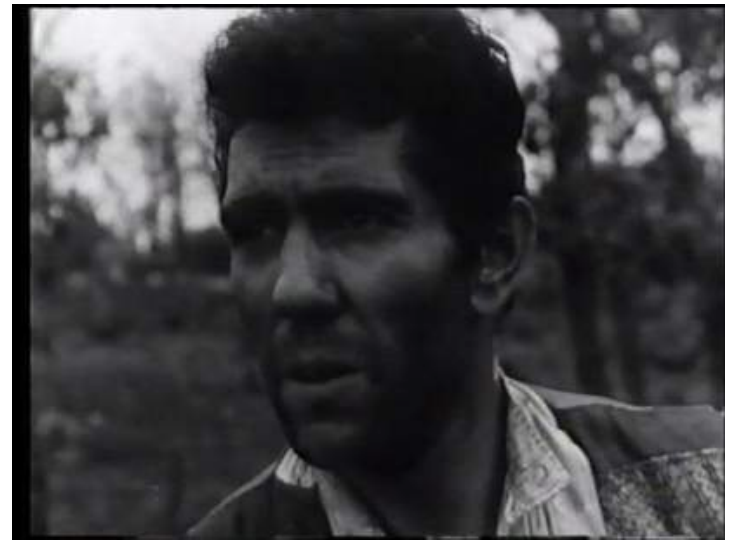

Figura 17b

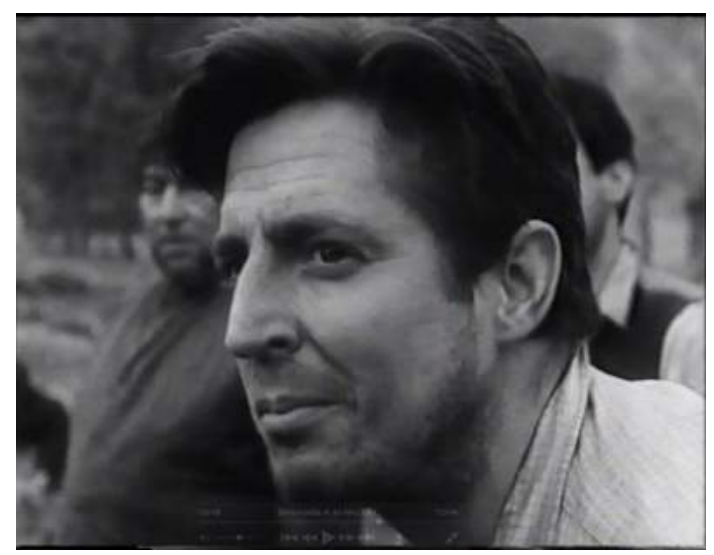

Figura 17d

Al caer la noche, Lucas y otro hombre aprovechan la oscuridad para asaltar la choza de Cruz. Se trata de una secuencia de gran violencia física debido al estado de embriaguez de los dos hombres decididos a aprovecharse sexualmente de la mujer. Pero esta consigue zafarse in extremis en la cumbre de la Niña Negra.

La inoperancia de la cuadrilla de carboneros pospone la resolución de la escena al día siguiente, cuando vuelve Juan al campamento. Primero el protagonista se enfrentará en un duelo de hachas con Lucas y luego se reanudará la búsqueda de Cruz. Resulta interesante constatar la duración prestada en el metraje a ambos sucesos. Mientras la persecución de Lucas se dilata durante la noche anterior y la mañana previa a la vuelta de Juan, 
además del tiempo que dura el duelo con Lucas, ocupando un total de cuatro minutos y veinte segundos de metraje, el rescate de Cruz ocupa dos minutos $y$ veinticinco segundos.

La película culmina con la readmisión social de Cruz a partir de su faceta procreadora. La secuencia consta de tres escenas, una primera en que Cruz, aún convaleciente, describe ante el grupo de carboneros un cuadro sintomático habitual en el inicio de la gestación (fig.18a). Una segunda de anuncio de la buena nueva al resto de la comunidad rural que comporta una celebración con música de carácter festivo, el repicar de las campanas y la expectación de los vecinos del lugar ante la llegada de Cruz a lomos de un asno (fig.18b). Una composición que remite a la iconografía bíblica de María y José en su viaje de huida a Egipto y que prepara la escena final de presentación del recién nacido a la Virgen del Valle. El plano final del filme lo protagoniza Cruz, ataviada con vestimentas blancas que le otorgan una luz sacralizada, sentada en el primer banco de la parroquia, un lugar que la encumbra como protagonista del gran acontecimiento que la superación de los problemas de infertilidad supone para esta comunidad rural. $Y$ que el párroco resume en las palabras que dirige a la Virgen: "Acoge a este cristiano, Virgen del Valle. No es solo una mujer quien te lo ofrece, es un pueblo entero" (fig.18c).

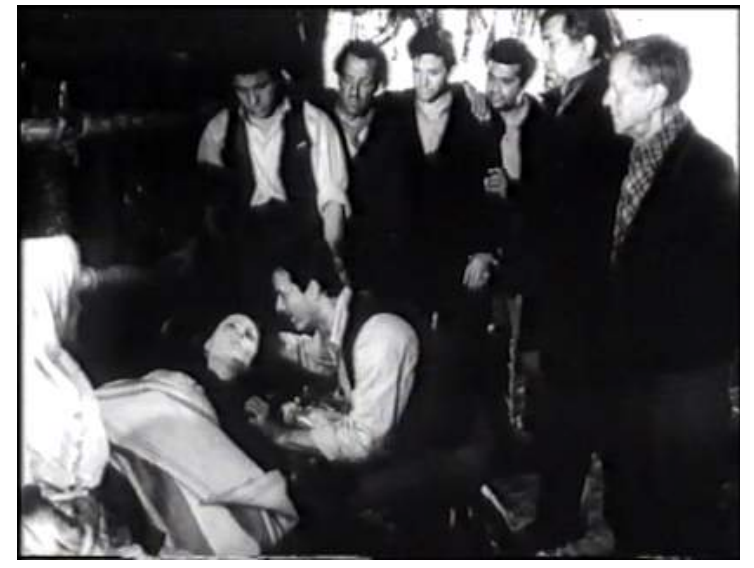

Figura 18a

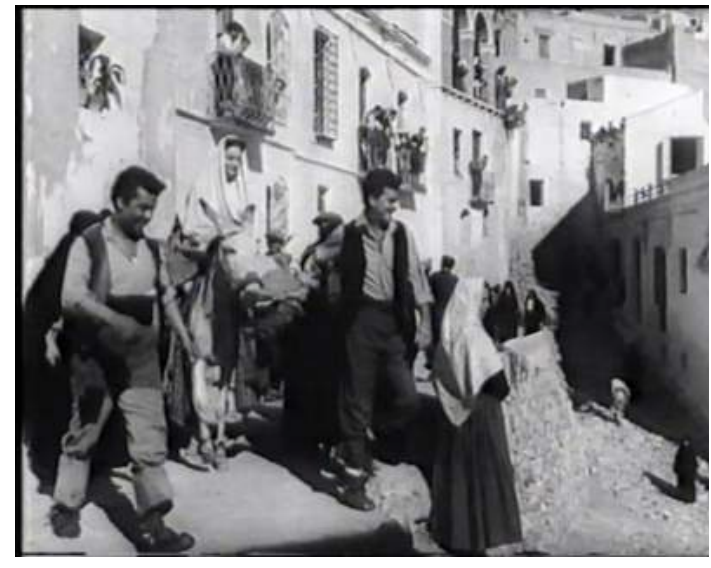

Figura 18b 


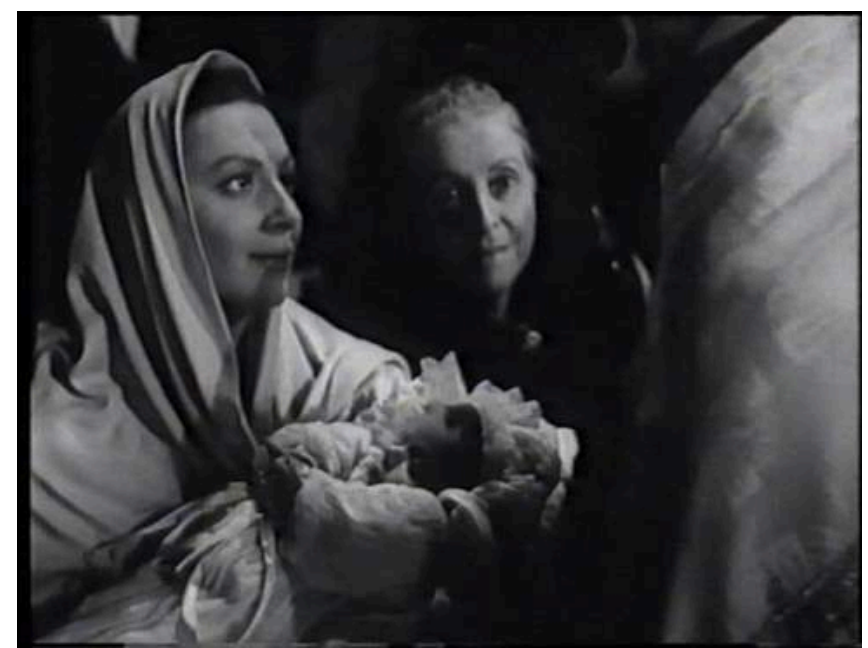

Figura 18c

La capacidad de procreación es la clave para la readmisión social de Cruz en Sierra maldita. Una capacidad que en el caso de Cañas y barro se torna en contra de su protagonista. Tal y como se describía en el resumen argumental de la película, Cañamel, sospechoso de las relaciones de su joven esposa, introduce una cláusula en su testamento por la que Nela quedaría despojada de su herencia en caso de iniciar una nueva relación sentimental. ${ }^{529} \mathrm{Y}$ así sucede en el transcurso narrativo, Nela y Tonet no pueden evitar amarse y fruto de ello nace un niño que Nela mandará ocultar para así mantener su estatus y el patrimonio del difunto marido.

Brevemente cabe recordar el perfil del personaje a partir de su tratamiento formal en el marco de la narración. Nela es una niña huérfana, al cargo de una tía que la maltrata. La situación de desamparo sitúa a la Nela adolescente ante la única opción de aceptar la propuesta de Cañamel, un hombre mayor que ella, de acogerla en su taberna. Una circunstancia que fundamenta la construcción del personaje en torno a los preceptos de ostentación y vanidad. Esta es la forma que adquiere la estigmatización del personaje femenino, en otras palabras, el castigo al afán por dirigir su

\footnotetext{
${ }^{529}$ En la secuencia de apertura del testamento, el notario lee: "Declaro heredera de todos mis bienes a mi mujer, sin mandas ni legados. Pero ordeno, que si ella vuelve a casarse o demuestra con su conducta mantener relaciones amorosos con un hombre, la parte legal de la fortuna de que puede disponer pase a mi cuñada y a su hijo Jaime, únicos parientes de mi primera mujer".
} 
desarrollo personal. Y que de alguna manera revela cierta conciencia crítica en la protagonista a diferencia de las mujeres de Condenados y Sierra maldita.

Retomando el desarrollo argumental, Nela se convierte en una mujer adulta mientras trabaja en la taberna de Cañamel, tiempo durante el cual se ha convertido en el foco de temor, y con ello de la ira, de Carmen y Samaruca, la primera esposa de Cañamel y la cuñada, respectivamente. También ahora es el objeto de deseo del hombre. En el acuerdo de matrimonio el hombre aporta todas sus posesiones y su estatus en la comunidad de El Palmar como aval de su proposición. Ella acepta con un escueto: "lo que usted quiera". Una transacción rápida que sitúa a la mujer en el mismo nivel que otras mercaderías con que negocia Cañamel. La formulación verbal del asentimiento de Nela discurre en la línea de negación de la mirada -y por tanto de la voluntad- de las protagonistas femeninas del drama rural.

El deseo de Cañamel por la protagonista también se extiende a los dos coprotagonistas masculinos, Jaime y Tonet. No obstante, el sentimiento de estima de los tres hombres hacia la protagonista no la salva de ser juzgada en algún momento por ellos mismos y por el resto de la comunidad, tachándola de vanidosa y situándola ante la disyuntiva de haber de escoger entre el estatus social y económico o su hijo, en otras palabras, entre su voluntad y las circunstancias impuestas. El rechazo a las pretensiones amorosas de Jaime se traduce en insulto seguido de la persecución de este y su madre con el objetivo de despojarla de su herencia ${ }^{530}$. También Tonet, en la escena en que conoce la noticia de su matrimonio con Cañamel dice comprender la transformación de la mujer (fig. 19). Al fijarse en el traje y las joyas que esta lleva, sentencia: "Cañamel sabe hacer bien las cosas y no le faltan onzas de oro para tenerte como una reina". Una declaración cargada

\footnotetext{
${ }^{530}$ Jaime también está presente en la escena en que Cañamel en plena disputa con la Samaruca le propone matrimonio a Nela. Tras aceptar Jaime decide abandonar el Palmar "Trabajaré en Valencia y nada nos faltará. No quiero ver a Nela ni a Cañamel. Nela es mala y da asco de toda esta porquería".
} 
de censura hacia el nuevo aspecto de Nela que contribuye a la concepción peyorativa del personaje.

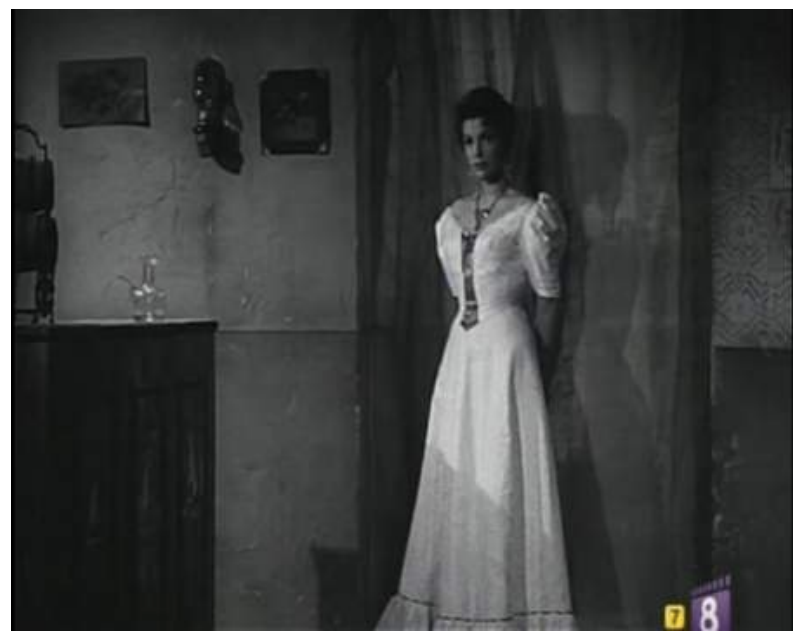

Figura 19

Finalmente, a pesar de la compasión y posterior amor de Cañamel por la protagonista, éste también ejerce violencia sobre ella incluyendo la citada cláusula en su testamento, una manipulación del desarrollo personal de la protagonista incluso después de su muerte.

Pero Nela es consciente de su situación como expresa en la escena en que ella y Tonet vuelven en barca a El Palmar:

- ¿Por qué te casaste, Nela?

- Pensé que no volverías. Te fuiste sin hablarme. Nunca tuve una carta tuya que me ayudara a seguir esperando. Desde pequeña todos me trataron a golpes, a gritos. Luego de mujer me di cuenta que me despreciaban, tu mismo preferías bailar en la plaza con la mejor vestida. Cañamel siempre fue bueno conmigo. Le daba pena cuando la Samaruca me mandaba hacer los trabajos más fuertes de la casa, y muchas veces discutieron por eso. Cuando murió su mujer yo le veía triste, desalentado, y un día me habló de casarse conmigo. No sabía qué contestar, me daba miedo decir que sí y por otra parte lo deseaba. Casándome con él lo tendría todo, se acababan los golpes, los gritos y en los días de fiesta podría abrir el baile en la plaza. Él me quiere, ha sido bueno conmigo, yo no puedo quererle, la Samaruca lo sabe, por eso ha sabido echar bien su veneno. 
Una situación que intentará combatir con el objetivo de realizarse personalmente, así lo expresa en la lectura del testamento de Cañamel: "Es una vergüenza, no puedo aceptarlo". Pero a diferencia de Cañamel, un personaje legitimado por su estatus económico, el ímpetu de la protagonista es juzgado en términos de codicia material. Es así como el transcurso narrativo desemboca en el castigo definitivo de Nela mediante la aceptación del hijo que la despojará de su fortuna y matará a Tonet. De hecho el abuelo hace responsable a Nela de la tragedia: "Ya puedes estar satisfecha de tu obra, mala mujer. Mal andaba Tonet desde que volvió a verte, y mal ha terminado. (...) Lo han matado. Tú le has matado. He visto su cuerpo entre las cañas y el barro del canal".

El arrozal de Toni es el escenario del crimen de sangre de Cañas y barro. Convertido en paradoja del ideal de vida tranquila y digna que el padre anhelaba para su hijo, quien termina por sentenciar:

"Tantos años batallando en el lago creyendo que amasaba una fortuna y estaba preparando, sin saberlo, tu tumba, hijo mío. Primero le he dedicado mi sudor y mis fuerzas, mis ilusiones y ahora, cuando había que abonarla, mis propias entrañas, mi hijo, mi sucesor, mi esperanza. Mi obra ha terminado. Sobre tu cadáver crecerá la cosecha como un mar de espías cobrizas, pero a mi ¿qué me quedará hacer en el mundo? Ánimo hija, la tierra cumplirá su misión".

En los tres casos analizados la especificidad del contexto rural se focaliza negativamente sobre los personajes femeninos. La Albufera valenciana, la montaña almeriense y la meseta castellana adquieren una función dramática que sustenta las tensiones entre el género femenino y el masculino. Un pulso que, como le sucede a Nela, ganará el orden patriarcal de sus respectivas comunidades rurales. En la secuencia final de Cañas y barro Nela se une al lamento de Toni y Marieta implorando perdón ante el cuerpo sin vida de Tonet (fig. 20a). La última escena subraya visualmente la aceptación de la culpa de la protagonista en que el reconocimiento del hijo automáticamente niega la consecución de sus deseos. (fig. 20b). La misión de la tierra de que hablaba Toni en relación a Nela es condenarla a vivir una vida en un entorno 
socialmente hostil y que ella ha rechazado vehementemente. En la línea de la teoría de Arocena sobre la negación de la mirada a las protagonistas de los dramas rurales, la solución formal al inconformismo de Nela es el más contundente de los tres analizados.

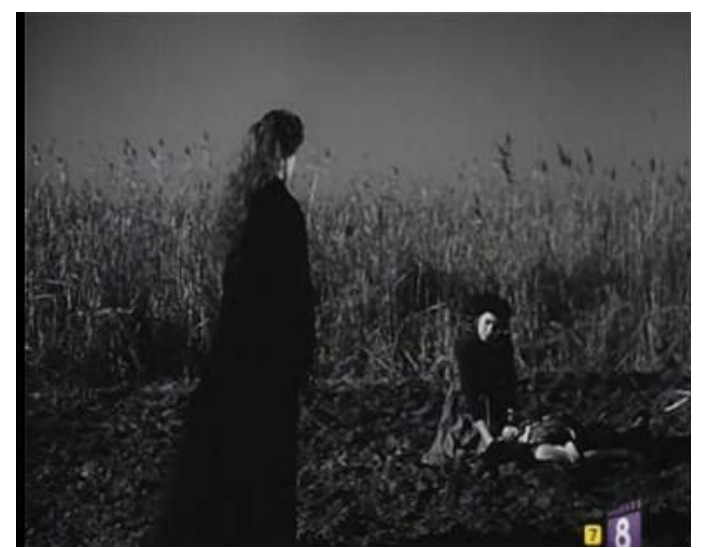

Figura 20a

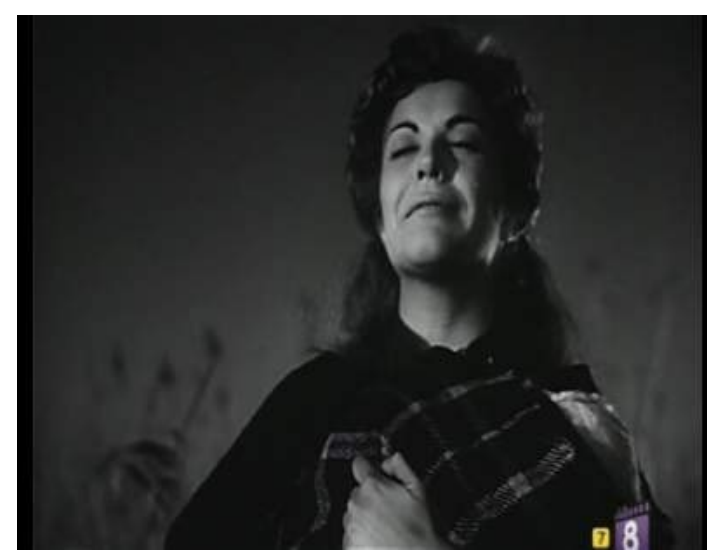

Figura 20b

El orden de análisis de los tres casos propuestos sugiere una trayectoria de los diferentes tratamientos del paisaje en el drama rural. Ubicados todos ellos en regiones españolas concretas, la abstracción de Condenados se centra exclusivamente en el poder dramático del paisaje obviando todo elemento localista. En cambio la leyenda de los pueblos de alta montaña almerienses de Sierra maldita comporta el abordaje de la constitución social de una comunidad rural, como también sucede en Cañas y barro, representación detallada de los tipos de una comunidad aldeana valenciana al hilo del argumento principal.

Los escenarios naturales donde se rodaron los dramas de Condenados, Sierra maldita y Cañas y barro sitúan estas películas en la línea de otras cinematografías europeas en busca del valor de los escenarios reales cuya fisicidad se materializa en los cuerpos de los personajes femeninos. Las llanuras castellanas de Condenados claman por encontrar una mano que las are, como subliminalmente permanece la expectante Aurelia, su dueña. Por su parte, la árida montaña almeriense de Sierra maldita perpetua el recelo de sus gentes hacia Cruz receptora, como le sucediese a la Niña Negra, de la 
agresión física del corpus masculino. Y finalmente Nela trata de sobrevivir en la isla de la Albufera valenciana que castiga toda individualidad que diverja de las normas de una comunidad al margen del progreso de la urbe. Una relación que convierte a las mujeres en más que metáforas, emanaciones del paisaje. Y que a su vez muestran, como sugiere Arocena, que "la existencia femenina siempre ha estado sujeta a su condición de mero significante que espera ser cargado de un significado independiente de los propuestos por el lenguaje patriarcal ${ }^{531}$ ". Una afirmación que comporta unas circunstancias de subordinación de los personajes femeninos en unos núcleos sociales que, regidos por los ciclos de la tierra, concentran en el arquetipo femenino sus temores y anhelos.

La Aurelia de Condenados, como ya le sucediese a Cruz, Nela o a la Julia en Un hombre va por el camino o a la protagonista de Con el viento solano, es un arquetipo femenino fuerte que lucha por sobrevivir en contextos adversos. Pero la norma patriarcal las afligirá, como es el caso, en clave sexual atendiendo al deseo que despiertan en los hombres y el temor del resto de mujeres. Una encrucijada de que da cuenta el trayecto narrativo concluyendo en la inmolación, la abnegación o la redención de las mujeres, siempre bajo la norma de los postulados nacionalcatólicos sobre la supuesta moral femenina en la España de mediados de siglo.

El arado, el regadío y el enriquecimiento de la tierra son los tres elementos constituyentes de la 'metáfora agraria' de la que habla Zubiaur ${ }^{532}$. La asimilación de la mujer a la tierra, entiéndase también de la creación de la vida al mundo agrario, ha estado presente a lo largo de todas las civilizaciones. Joseph Campbell ya señalaba cómo "la semilla se erigió en símbolo mágico del ciclo sin fin [...] cuando los pueblos primitivos pasaron de la caza a la agricultura ${ }^{533 "}$ siendo retomado por las grandes religiones en sus argumentos en torno a la vida y la muerte, el principio y el fin. $Y$ del mismo modo, en las religiones primitivas, el cultivo de la tierra quedaba ligado al acto

\footnotetext{
${ }^{531}$ Arocena, 2010: 9.

${ }^{532}$ Zubiaur, 2013: 227.

533 Ibídem.
} 
generador "desde las creencias védicas hasta las islámicas, pasando por las culturas griega o romana ${ }^{534 " . ~ E n ~ o p i n i o ́ n ~ d e ~ M i r c e a ~ E l i a d e ~ q u e ~ t a m b i e ́ n ~}$ identifica los elementos participantes de la conjunción de este símbolo-ritual, "la identificación de la mujer con la tierra de labranza, la identificación del falo con el arado, la identificación del trabajo agrícola con el acto generador ${ }^{535 " .}$ Unos pensamientos que abren una nueva vía desde la que interpretar la cuestión mujer-tierra. En Condenados Aurelia es una mujer joven, bella y fuerte que trata de sobrevivir en unas circunstancias hostiles las cuales la sitúan al mando de unas tierras, inabarcables en extensión e improductivas, que también la estigmatizan socialmente convirtiéndola de sujeto sacrificado en culpable. Una situación para la cual la única solución es la llegada de un compañero masculino que, a la vez que la ayuda en las tareas del campo, reactive su capacidad reproductiva, como le sucede a Cruz en Sierra maldita. El desenlace de cada narración resulta bien distinto: mientras que la posibilidad de procrear comporta la readmisión social de Cruz, el poder de atracción de Aurelia -y Nela- sobre el género masculino desencadena una tragedia de sangre. Las dos mujeres se encuentran en una lapso de espera, es decir de infecundidad, reactivado con la llegada de los respectivos Juanes.

\subsection{El paisaje rural en clave identitaria}

La urgencia con que el aparato franquista exigía la definición de un imaginario nacional reconocible dentro y fuera del país alcanzó gran parte de la producción artístico-cultural de los años 50, como sucede en los textos críticos y promocionales sobre Condenados, Sierra maldita y Cañas y barro.

Las líneas editoriales de Radiocinema y Primer Plano, coincidían en identificar el localismo del cine rural con la esencia nacional. Atendiendo a la naturaleza fundacional de las dos cabeceras, ambas surgieron al amparo del Departamento Nacional de Cinematografía en tiempos de Manuel Augusto García Viñolas. En ella se dieron cita intelectuales falangistas con el objetivo

\footnotetext{
${ }_{534}^{534}$ En Tratado de historia de las religiones, 1981. Ibídem.

${ }^{535}$ Eliade, 1981: 266.
} 
de definir una estética, y un cine, nacional. Sobre Primer Plano, Jorge Nieto afirma era " la portavoz oficial del cine que el régimen desea", en sus textos confluyen "las aspiraciones estéticas e ideológicas que los falangistas ponen en el arte, su estilo, las necesidades cinematográficas del nuevo Estado y un marcado carácter popular ${ }^{536 " . ~ Y a ~ d e s d e ~ s u ~ f u n d a c i o ́ n ~ l a ~ r e v i s t a ~ m o s t r a b a ~ s u ~}$ preocupación por la definición del concepto 'españolidad' concretada en la vía del casticismo, y que constituiría la línea editorial. Lo mismo sucedía con Radiocinema hasta el punto de asumir la heterogeneidad del territorio español justificando cada regionalismo como ejemplo del todo nacional. El texto que firma Bruno es significativo de esta línea interpretativa: "Lo más destacable es que se nos brinda un trozo de España no consabido. La Patria es inmensamente varia; la cinematografía debe recoger todos sus diversos aspectos $^{537 "}$.

Un ejemplo es el texto de Antonio Serrano Pareja sobre Sierra maldita en Radiocinema ${ }^{538}$ :

"Drama intenso que discurre entre la cuadrada arquitectura del pueblo serrano para perderse entre los riscos de la Niña Negra, en donde se matizan o se acentúan las pasiones entre los hombres. [...] Y sobre todo, la vigilia constante, el servicio de nuestro cine para ofrecer al mundo la variante de nuestra geografía, de nuestros modos y de nuestro temperamento".

Para a continuación valorarlo dentro del corpus artístico y cultural que serviría en la constitución la nueva imagen nacional acorde a los nuevos postulados del contexto diplomático. Sierra maldita era:

"Cine típicamente español, fuerte y entero, rodado en exteriores naturales de belleza incomparable, con valores para intentar la conquista del mundo [...] una línea de cine español, sin concesiones al folklore de exportación, eminentemente racial, marca un camino y

\footnotetext{
${ }^{536}$ Nieto, 2009: 83.

${ }^{537}$ Radiocinema. Núm. 224, noviembre de 1954.

${ }^{538}$ Otro ejemplo es el texto de Alejandro de España. "Un triunfo [...] del cine racial, recto, de honda preocupación nacional. Un cine distinto y español ${ }^{538}$. Primer Plano. Núm. 742. 2 enero de 1955, año XV..
} 
señala la meta que puede expandir nuestro celuloide por doquier, para acreditar así los auténticos valores nacionales ${ }^{539 " .}$

Del mismo modo se entendía Condenados. Lo distintivo de una región maltratada por el clima se tornaba fundamento de la identidad nacional, al interpretar la adversidad real del terruño manchego desde perspectivas románticas con descripciones como, "el ambiente, además, acre y rudo del medio natural prestará a su acento la fuerza necesaria y admirable ${ }^{540 "}$. Concluyendo que "aquí está la formidable tragedia castellana, engranaje angustioso de episodios y documental inapreciable de Castilla, estameña penitencial de España". Condenados ponía en imágenes el "sayal de España", "esa gran plana de oro viejo que es la gloriosa estepa central de España, ese desierto donde, casi monacalmente, se recogen la austeridad y la contemplación españolas ${ }^{541 "}$.

Por su parte Sierra maldita fue publicitada como la superación de la Andalucía tópica "fácil, de chato, pandereta y guitarra ${ }^{542 ", ~ d e ~ " l a s ~ t r i v i a l e s ~}$ comedietas folklóricas y de aquellos vetustos folletines decimonónicos" ${ }^{543}$ llegando a considerarse "la primera película racialmente española" ${ }^{544}$ según los críticos de Radiocinema. Unas deducciones que, sin embargo, otorgan una dimensión simbólica a su espacio rural sobre lo que sus autores nunca se declararon haberse planteado. No existe registro de declaraciones de Antonio del Amo al respecto. Sí de su guionista, José Luis Dibildos, que en entrevista para el programa La noche del cine españo/ ${ }^{545}$ explicaba cómo la localización en el espacio rural andaluz vino dada por el tema dramático del caso probado de esterilidad de los altos pueblos de montaña por causas climatológicas. El mismo programa televisivo recogía las declaraciones del jefe de decorados, Eduardo Torre de la Fuente, que justificaba la elección del enclave almeriense con el pretexto de mostrar la tradición local de identificar

\footnotetext{
${ }_{539}$ Radiocinema. Núm. 236. Enero de 1955.

${ }^{540}$ Primer Plano. Núm. 673. 6 de septiembre de 1953. Año XIII.

541 Ídem.

${ }^{542}$ Radiocinema. Núm. 190. Marzo de 1954.

${ }_{543}$ Primer Plano. Núm. 739. 12 de diciembre de 1954, año XIV.

${ }^{544}$ Radiocinema. Núm. 198. Marzo de 1954.

${ }^{545}$ Consultado a partir de una copia en VHS de parte del programa La noche del cine español conducido por Fernando Méndez-Leite y emitido por RTVE en el canal 2 entre 1984 y 1986, del que se desconoce la fecha exacta.
} 
con sus indumentarias a las mujeres oriundas en tres categorías, dependiendo de su estado civil. Una información que en boca del realizador del filme hubiese tenido mayor significación pero que, atendiendo al resultado final de Sierra maldita, refuerza las lecturas que vieron en el elemento social la transgresión del imaginario folklórico andaluz.

Mientras que de Orduña encontraba en los exteriores de la Albufera el naturalismo que fundamentaba su idea de realismo poético, las revista Primer Plano y Radiocinema leían el paisaje de Cañas y barro como la "luz de naturaleza" en la misma frase que "paraíso de luces de España" ${ }^{546}$. Sentenciando que "Cañas y barro es una pintura espléndida de la belleza valenciana. Y el cine español debe reflejar la belleza española ${ }^{547 " .}$

Un texto que resume todas las ideas de encumbramiento del regionalismo valenciano como sinécdoque de la identidad nacional es el publicado en Primer Plano:

"En nuestra maravillosa variedad de tierras y de almas, Valencia resalta por su soberanos sellos y estilo estéticos. Lugares, tierras, aguas y gentes levantinas reclaman el reflejo en la pantalla, y siempre que las sepa aprovechar con arte y sentimiento nuestra producción [,] será logrado un cine propio, un cine original. Verdaderamente universal. En Cañas y barro, la gran pantalla caída de la Albufera sorprenderá a todos con la refracción luminosísima de unos lugares y unos personajes absolutamente originales en todo el panorama de la cinematografía mundial ${ }^{548 "}$.

Finalmente, no se han encontrado declaraciones de Mur Oti, del Amo o de Orduña sobre las intenciones que fundamentaron sus los usos espacio rural en sus películas. Tampoco constan en la nómina de profesionales presentes en el encuentro salmantino. En definitiva las informaciones sobre sus perfiles ideológicos es insuficiente para localizar sus películas dentro del citado contexto político de definición nacional. Si bien es cierto de Orduña cultivó una filmografía identificada de 'oficialista' por cuanto contaba con el

\footnotetext{
${ }^{546}$ Primer Plano. Núm. 706. 25 de abril. Año XIV.

${ }^{547}$ Primer Plano. Núm. 711. 30 de mayo de 1954. Año XIX.

${ }^{548}$ Ibídem.
} 
beneplácito del régimen franquista. No obstante, y como se ha argumentado, el valor simbólico de los paisajes de Condenados, Sierra maldita y Cañas y barro fue otorgado con posterioridad, lo que pone de manifiesto el pliégame de un sector de la crítica cinematográfica a la urgencia por definir un corpus referencial nacional. 


\section{El entorno rural español. Territorio de conflicto social}

"When [the relations between human being and the land] describe the ways one has of inhabiting the land owning it, fighting for it, or working on it, the land tends to be represented in terms of territory ${ }^{549,}$.

La actividad diaria de la población rural se concreta en el trabajo de la tierra, factor diferencial de esta comunidad "whose lives and daily activities give this space its meaning and value ${ }^{550 "}$. De ahí que el entorno rural se erija en el contendedor que conserva "más aún que antiguos usos y costumbres, la tradición del trabajo fatigoso, de la vida sobria y ruda y de la libertad en la pobreza 551 ", caracteres inherentes al habitante rural. Como se ha abordado anteriormente, los núcleos rurales se congregan alrededor de la comunidad aldeana englobada en la comunidad local, entendida esta como grupo social basado en un sistema de lazos y relaciones; intereses comunes, pautas compartidas y normas y valores aceptados; los cuales muestran una conciencia de ser distinta a la de otros grupos ${ }^{552}$. En concreto la comunidad aldeana es un grupo primario, que la sociología rural identifica por los rasgos de parentesco, el apego a la tierra, los ligámenes de vecindad, el patrimonialismo, el miedo al progreso, "factores que constituyen las especiales condiciones ambientales de las que la familia campesina, con sus funciones distintivas culturales, educativas y de seguridad social, deriva su existencia y durabilidad ${ }^{553 "}$. En definitiva, una serie de rasgos distintivos presentes, en mayor o menor medida, en los argumentos de las ficciones rurales.

\footnotetext{
549 Lefebvre, 2006: 53.

${ }^{550}$ Fowler; Helfield, 2006: 6.

${ }^{551}$ Herzog, 1967: 250.

${ }^{552}$ Hiller, A. (1955). Definition of community: areas of agreement, "Rural Sociology", vol. XX, 119. A partir de la cita en Galeski, 1977: 133.

${ }^{553}$ Galeski, 1977: 113.
} 


\subsection{El trabajo en la definición del estamento campesino}

La identificación sociológica del estamento campesino a partir del laboreo de la tierra es un recurso frecuente en la caracterización de los personajes de las ficciones rurales, pero no lo es el desarrollo de las tramas argumentales en base a los avatares derivados de dichos trabajos. Del corpus de cine rural de la década de los años cincuenta tres títulos comprenden en menor o mayor medida esta premisa. La venganza, de Juan Antonio Bardem, 1957, transcurre a partir de episodios relativos a la condición de temporeros del grupo protagonista. Amanecer en Puerta Oscura, de José María Forqué, 1957, arranca con una secuencia de alzamiento de los trabajadores de una mina, profesión también de los protagonistas de La guerra de Dios de Rafael Gil, 1953, que incluye otro episodio de revuelta laboral.

Este análisis constituye un recorrido progresivo atendiendo al protagonismo -en términos cuantitativos- de la faceta del trabajo en las diferentes representaciones de la vida en el entorno rural español, esto es como territorio de conflicto social. Lo que supone una mirada del entorno rural como territorio, siguiendo la secuencia de Martin Lefebvre. De lo que se concluye que el entorno rural de estas tres ficciones es un territorio vivido del que emergen conflictos de clase, de moral y de valores al cuestionar la razón de ser de los habitantes del campo español.

\subsection{Amanecer en Puerta Oscura, 1957, territorio pretérito}

Un hecho habitual del cine de este momento es la identificación del estamento rural con la minería como sucede en Amanecer en Puerta Oscura de José María Forqué y La guerra de Dios de Rafael Gil. La actividad minera presupone un fuerte vínculo con el entorno natural explotado, principalmente, por una comunidad aldeana, en los términos descritos por Galeski ${ }^{554}$.

${ }^{554}$ Galeski, 1977: 151. 
El conflicto de Amanecer en Puerta Oscura se origina a raíz de la sublevación de un grupo de mineros contra el maltrato de uno de los capataces. El enfrentamiento se salda con un doble homicidio y la huida de los culpables. La sierra les servirá de refugio donde se encuentran con un bandolero que, en su quehacer al margen de la ley, les ayuda hasta que son capturados por la Guardia Civil y condenados a expensas de recibir un indulto por orden religiosa. El tratamiento formal del argumento descrito divide el filme en tres partes: una primera de carácter social que comprende el alzamiento de los trabajadores de la mina; una segunda enmarcada en el género del bandolerismo y una tercera que responde a los presupuestos adoctrinadores del cine religioso. En palabras de Agustín Sánchez Vidal:

"En un principio parecería que nos dispusiéramos a contemplar un film sobre la colonización y la lucha de clases en la Andalucía minera del siglo XIX, adobado con nociones laterales muy de los años cincuenta, como el 'compromiso' y otras tomas de conciencia social. Pero semejante desarrollo no parecía muy viable en la España de 1957. La censura pronto mostró su preocupación por el enfoque dado a la compañía extranjera de minas que, según ella, podía molestar a los americanos (aunque en la ficción se trataba claramente de ingleses). Y se opuso rotundamente a que la Guardia Civil errara el blanco -como se preveía en una de las secuencias- porque, en su opinión, eso era impensable en la Benemérita. En ese contexto, es fácil imaginar lo que pudo dar de sí el arranque social ${ }^{555 " .}$.

Formalmente la secuencia de revuelta laboral discurre del siguiente modo. La apertura en fundido da paso a una breve secuencia de tres planos generales que muestran el recorrido de un vagón que emerge a la superficie por medio de una caña de pozo y vuelca el material que porta en la cuba de un tren. El transcurso de estos tres planos es utilizado para sobreimprimir un cartel en movimiento ascendente que alude a la veracidad de los hechos que se van a desarrollar:

"No es todo inventado en esta historia. Su desenlace está basado en un hecho real que se repite, año tras año, en la Madrugada del Miércoles Santo.

\footnotetext{
${ }^{555}$ Pérez (Coord.), 1997: 413-415.
} 
La historia comienza con un hecho que pudo ocurrir en la Andalucía del siglo XIX, cuando la inquietud política y el malestar social condicionaban la vida del país y justificaban la lucha y la revuelta.

Muchas minas eran entregadas a compañías extranjeras en medio de la indiferencia general. En aquella Andalucía profunda y trágica, dentro de su cante hondo, detrás de la alegría, latían graves problemas. Bajo el sol, hervía la sangre de los mineros andaluces...".

Por el lado superior derecho del encuadre entra un tren de carga seguido por un leve movimiento de cámara hasta el ángulo inferior izquierdo. Se trata de un plano de situación de un enclave montañoso indefinido de Andalucía. La sucesión de los títulos de crédito va acompañada de una serie de planos que, a lo largo de un minuto, dan cuenta de un ambiente minero con unos personajes difícilmente reconocibles debido a la apertura del encuadre y la banda de sonido a base de ruidos de maquinarias y herramientas metálicas. A continuación tiene lugar un altercado en que un hombre empuja a otro por la espalda, un tercero sale en su defensa y ataca al primero. Se produce una elipsis de contenido en que el plano visual muestra una doble explosión que adquiere forma de estruendo en el plano sonoro. Un preámbulo que termina con la sobreimpresión del título del filme (fig.21).

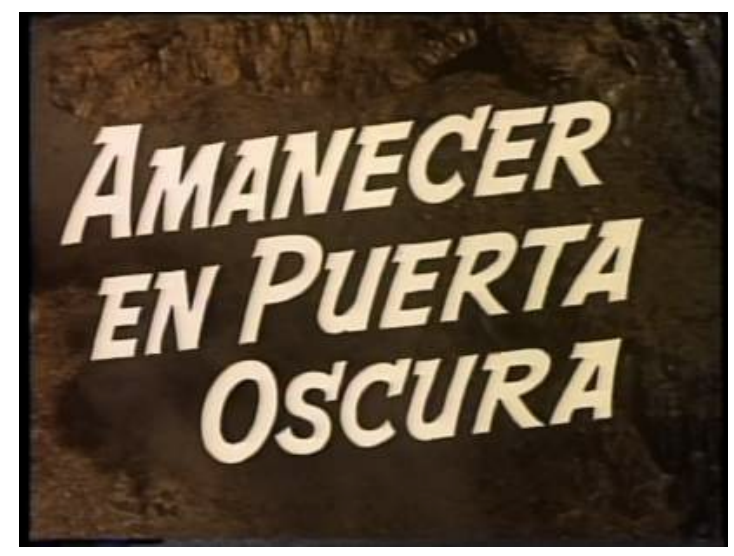

Figura 21

Esta secuencia localiza la trama argumental en un enclave hostil narrativamente por la violencia de las acciones y estéticamente por la 
atmósfera oscura del espacio y sus connotaciones alienantes sobre los trabajadores.

La explicación de los hechos da comienzo en la secuencia siguiente cuando la cámara sigue a un hombre a caballo que llega a un enclave urbano en busca de don Pedro Guzmán -Alberto Farnese, el ingeniero de la mina. Los dos hombres se dirigen a las oficinas de la mina donde el director y los ingenieros le piden negociar con el responsable del altercado. Se trata de Andrés Ruiz -Luis Peña, antiguo conocido de Guzmán. Los dirigentes se dirigen a caballo a la mina mientras una línea melódica de guitarra confiere el sentido rítmico a la escena. Los mineros, que habían quedado fuera de cuadro, vuelven a escena. Ahora en cambio prevalece el silencio y la pasividad del grupo a la espera de la reacción de los dirigentes de la explotación (fig. 22). Guzmán baja a dialogar con Andrés culpable confeso del asesinato de John Parry, el abusivo capataz. En un acto de solidaridad uno de los compañeros interviene: "Eso no es posible. No ha sido solo Andrés, a Parry lo hemos matado entre todos, que nos lleven a todos". Se trata de una escena de gran carga simbólica por la camaradería de los trabajadores, un sentimiento que pronto alcanza a Guzmán al verse traicionado por el director de la mina. La tensión de la escena se resuelve con el disparo de Guzmán contra el director, la justificación narrativa para que este se una a su amigo en la huida a la sierra.

A partir de este momento el montaje en paralelo muestra la acción en dos escenarios diferentes. Por una parte, el recorrido de los dos homicidas por la sierra y por otra, las pesquisas de la Guardia Civil para encontrar a los fugitivos. En la primera línea de acción Andrés y Guzmán llegan a una cueva habitada en el pasado por Andrés y su mujer, que rápidamente también llega al lugar. La temeridad de la mujer revela el paradero de los fugitivos a la Guardia Civil consiguiendo, tras un tiroteo, su rendición. Pero inesperadamente entra en escena un quinto personaje, el bandolero Juan Cuenca -Francisco Rabal- que auxilia a los dos hombres a cambio de una recompensa (fig. 23). 


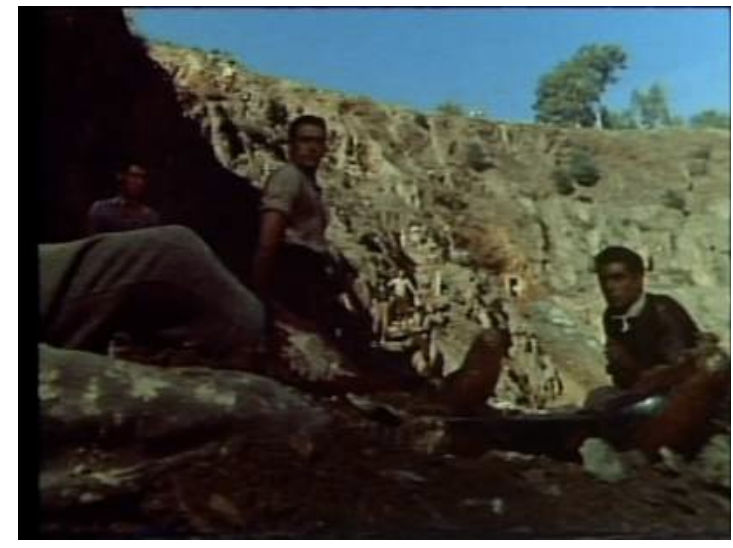

Figura 22

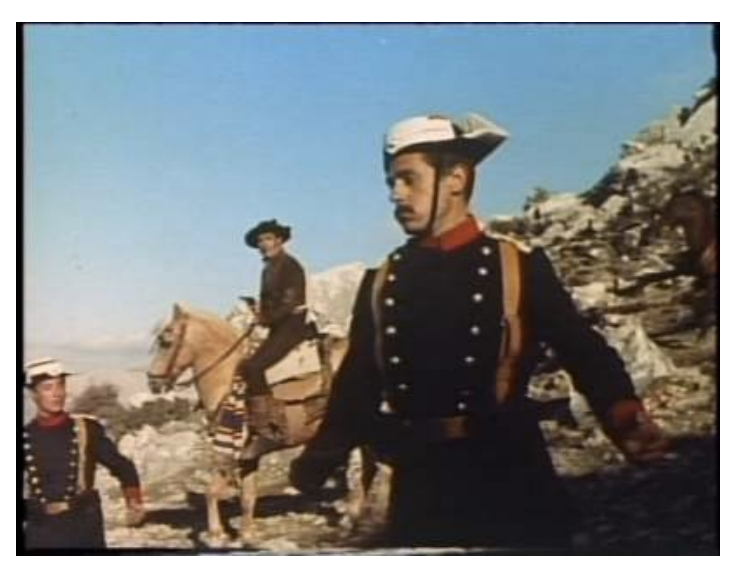

Figura 23

La entrada del personaje femenino como elemento melodramático y del bandolero como folclórico desvían la línea social de la secuencia de arranque hacia el western con toques melodramáticos. $Y$ más tarde la introducción del indulto, durante la ceremonia de la madrugada del Miércoles Santo a cargo de la cofradía de Nuestro Padre Jesús el Rico de Málaga, produce una segunda deriva hacia el cine religioso. Por otra parte, esta es la única referencia y localización verídica de las mencionadas en el prólogo. Cabe retornar en este punto a la función del cartel inicial con el fin de constatar las paradojas que se plantean de la comparación de las intenciones iniciales con el resultado final de Amanecer en Puerta Oscura. La representación de un conflicto social del entorno rural como detonante de la trama se resuelve por la vía de lo folclórico y religioso de una España pretérita. El análisis sintáctico del cartel inicial revela el uso de la estructura gramatical afirmativa: "Su desenlace está basado en un hecho real que se repite año tras año". Constatación de la veracidad de los hechos de la ceremonia religiosa de la madrugada del Miércoles Santo andaluz. En contraste con la perífrasis verbal de posibilidad: "La historia comienza con un hecho que pudo ocurrir en la Andalucía del siglo XIX", lo que resta rigor testimonial a los hechos de la revuelta laboral en la mina. De lo que se concluye que el llamado episodio social queda supeditado al conjunto dramático del western-cine religioso que resulta ser Amanecer en Puerta Oscura. 
En la línea de esta interpretación discurrió la única reseña publicada sobre la película de Forqué en la revista Primer Plano ${ }^{556}$. Teniendo en cuenta la línea editorial de la revista antes mencionada, el texto se centra en el trabajo actoral de Francisco Rabal y de la interpretación de su personaje en su vertiente folclórica. "Amanecer en Puerta Oscura [...] es la historia de Juan Cuenca un hombre manchado por un delito de sangre que es redimido durante una ceremonia religiosa". El filme se localiza dentro de un género que "por sus tipos, paisajes y reflejo de las costumbres [...] pertenece al estilo clásico del cine español”. Argumentos que se repetían en el único párrafo dedicado a la película dentro de un texto dedicado al anuncio de la edición 57 del Festival de Cine de Berlín en que Amanecer en Puerta Oscura representaba la cuota española.

Finalmente, sobre el espacio en que discurre el conflicto laboral. La mina es un lugar desapacible cuya explotación conlleva un alto grado de peligrosidad y requiere de gran esfuerzo físico. La tosquedad física es uno de los atributos principales de los trabajadores de estos lugares, una característica que en su traslación fílmica da lugar a un arquetipo terco en formas y rudo en aspecto físico. $Y$ a un espacio hostil donde predomina el enfrentamiento físico entre trabajadores. La falta de diálogo de este enclave será uno de los motivos por los que, diegéticamente, se presupone el abuso de poder del capataz obligando a los trabajadores a responder físicamente. El personaje del capataz John Parry se presenta en la faceta de alcohólico y los trabajadores, estéticamente, constituyen un todo homogéneo que forman parte del paisaje minero como la maquinaria o las acciones de extracción. En la cuarta escena de la secuencia de levantamiento, los mineros tienen la oportunidad de expresarse por si mismos. Es un momento que aprovechan para escenificar el sentimiento de camaradería del que hablaba Galeski en la constitución de las comunidades rurales. Con ellos empatizan Don Guzmán y Juan Cuenca que, desde su condición al margen de la ley, entiende la acción de los mineros como subversión de la jerarquía establecida. Se trata de un conflicto común en los espacios rurales pero excepcional en su traslación

\footnotetext{
${ }^{556}$ Primer Plano, año XVII. 16 de junio de 1957.
} 
cinematográfica, y que sin embargo, sentencia Sánchez Vidal, deriva en una "parábola actualizada del Buen Ladrón, dejando en la estacada a los dos rebeldes sociales que ponían en marcha todo el mecanismo de la acción ${ }^{557 " .}$

\subsection{La guerra de Dios, 1953, territorio evangelizado}

La deriva religiosa del episodio de insurgencia sindical de Amanecer en Puerta Oscura también condiciona el desarrollo del conflicto social de $\mathrm{La}$ guerra de Dios. En la película de Rafael Gil el protagonista es el cura Andrés Mendoza -Claude Laydu- que recién ordenado es destinado a Aldemoz, una pequeña localidad dedicada a la explotación minera. Mendoza se encuentra con una comunidad rural regida por una fuerte división de clases, escenario idóneo para poner en práctica sus planteamientos filosófico-teológicos en torno a la justicia social ${ }^{55}$. Es por ello que el joven cura mediará entre don César -Marco Davo- dueño de la mina, y los trabajadores encabezados por Martín -Francisco Rabal, con el objetivo de conseguir "la hermandad de los hombres de España", tal y como anuncia el cartel inicial del filme.

Atendiendo a la trayectoria de su guionista La guerra de Dios se inscribe en el seno del cine religioso debido a que fue producida por la empresa de Vicente Escrivá ${ }^{59}$, autor de La mies es mucha, 1948 o Balarrasa, 1950. Y que su realizador, Rafael Gil, posee una extensa nómina de títulos del género entre los que se cuentan Sor Intrépida, 1952, El beso de Judas, 1954 y Un traje blanco, $1956^{560}$. Lo que explicaría la confluencia de la línea argumental social con la religiosa, como estrategia para reconducir las tensiones generadas en el conflicto laboral, remarcando la centralidad de la figura del cura.

\footnotetext{
${ }^{557}$ Pérez (Coord.), 1997: 413-415.

${ }^{558}$ Unas ideas basadas en los pensamientos de Santo Tomás de Aquino plasmados en Summa Theologica en el siglo XIII. Obviando, como remarca Ángel A. Pérez Gómez, las encíclicas sociales de los papas del s. XX. En Ídem: 331-333.

${ }_{559}^{5}$ Véase A. Rubio (2013). Vicente Escrivá. La película de una España.

${ }^{560}$ Una colaboración que daba inicio al ciclo de cine religioso de la productora Aspa Films.
} 
Desde un punto de vista descriptivo el emplazamiento de la ficción tiene lugar en una aldea de aspecto generalmente humilde con las casas de piedra de los mineros, además de la casa de don César, la Iglesia y la mina. Desde una perspectiva sociológica La guerra de Dios describe una comunidad rural formada por la clase trabajadora -hombres de carácter terco derivado de su profesión- y las autoridades locales habituales: don César en calidad de patrón de la única empresa del lugar, el alcalde y el doctor Quesada, acostumbrados todos ellos al favor del representante eclesiástico. Una circunstancia que conducirá a la desconfianza de los mineros hacia el cura, configurándose así el contexto para el conflicto dramático. Finalmente, esta división de clases se traslada a los niños, obligados a odiarse por imposición de los adultos.

El episodio de conflicto social consiste en un plante general de los trabajadores de la mina Estrella. La secuencia arranca con un fundido de apertura que muestra en escenas consecutivas los acontecimientos acaecidos en el despacho de don César y de la bocamina. La primera escena tiene lugar en las oficinas donde se encuentran don César, el doctor y el secretario desde donde se escucha la sirena de una alarma. El doctor -José Sepúlveda- se dirige a la bocamina. La cámara cambia de escenario para mostrar el trajín en las inmediaciones de la mina donde llegan trabajadores, el doctor y el cura. Mientras, en las oficinas el secretario advierte de la crispación entre los trabajadores alegando que "la gente conoce sus derechos y ahora cuentan con alguien que puede remover todo esto. No se puede jugar con las leyes". De vuelta a la mina, un grupo de trabajadores carga con el trabajador accidentado. En un primer reconocimiento el doctor afirma que este ha sufrido un desmayo, pero es interrumpido por el cura para que certifique su defunción (fig. 24a y b). Este es uno de los momentos álgidos del drama de La guerra de Dios, construido en base a planos cortos de los rostros abatidos de los mineros y subrayado en la banda sonora por una línea melódica de carácter lento con base de instrumentos de viento y cuerda. A continuación el padre Mendoza confronta verbalmente al médico obligándole a cerciorarse de su diagnóstico. La línea melódica prosigue en crescendo hasta la entrada de unos tambores justo en el instante en que el 
doctor toma el pulso al difunto. La tensión en el ambiente sigue en aumento apoyada en planos de los rostros de los mineros en silencio hasta que, coincidiendo con el decrescendo de la línea melódica, Barrena -Fernando Sancho- reacciona tomando por el cuello de la chaqueta al doctor. El padre Mendoza intercede y ante el enfado del minero exclama: "Es a ti a quien he ayudado. Porque con la violencia no hubierais hecho otra cosa que perder vuestra razón" (fig. 24c).

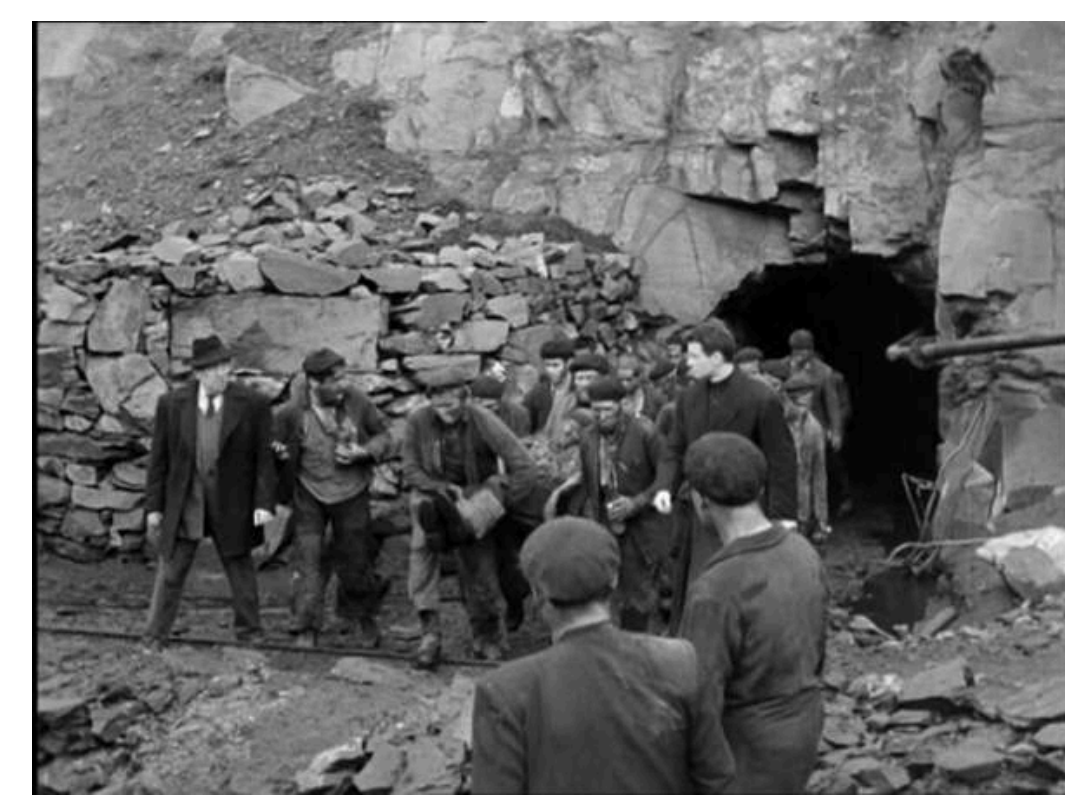

Figura 24a

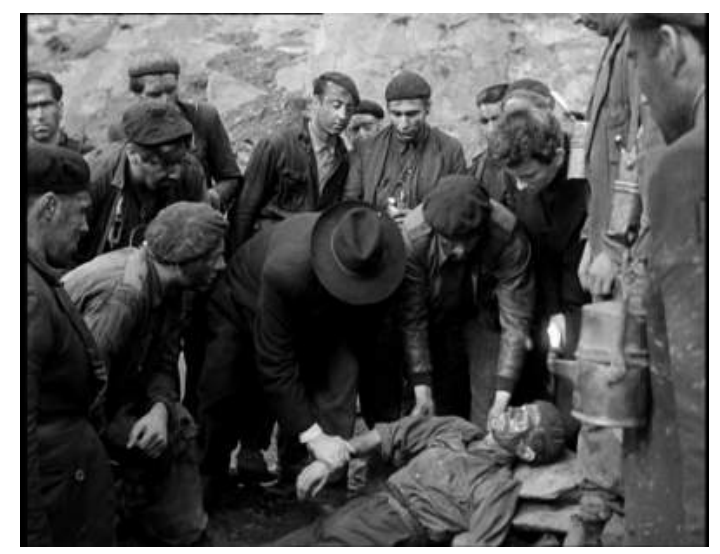

Figura 24b

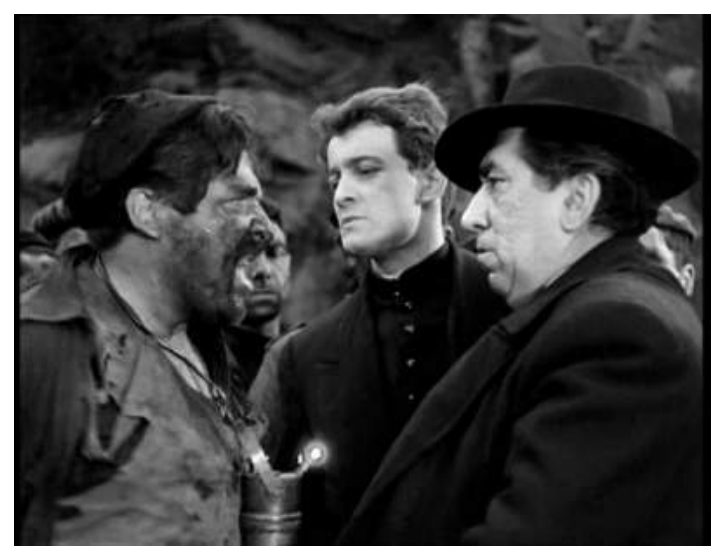

Figura 24c 
Un fundido encadenado enlaza con la segunda secuencia de confrontación de los mineros y don César. Desde un ángulo levemente picado de la plaza de la aldea la cámara capta a los mineros en dirección a la casa del patrón. Es de noche, los hombres avanzan cabizbajos y entre ellos se encuentra Martín seguido por la grúa de cámara en un breve travelling. La escena se subraya por una línea melódica de carácter dramático que identifica la acción de los mineros. Por montaje paralelo se muestra la acción del interior de la casa, con el secretario nervioso y don César esperando la llegada de los mineros. Ya en el interior de la casona, los trabajadores se agrupan en la entrada. Don César aparece desde el punto alto de una escalera. El personaje de Rabal actúa de portavoz del grupo demandando la readmisión de Barrena. La confrontación se resuelve formalmente mediante plano y contraplano con un ligero contrapicado en el encuadre de don César y de picado para el grupo de mineros. Un subrayado visual de la división de poder existente (fig. 25 a y b).

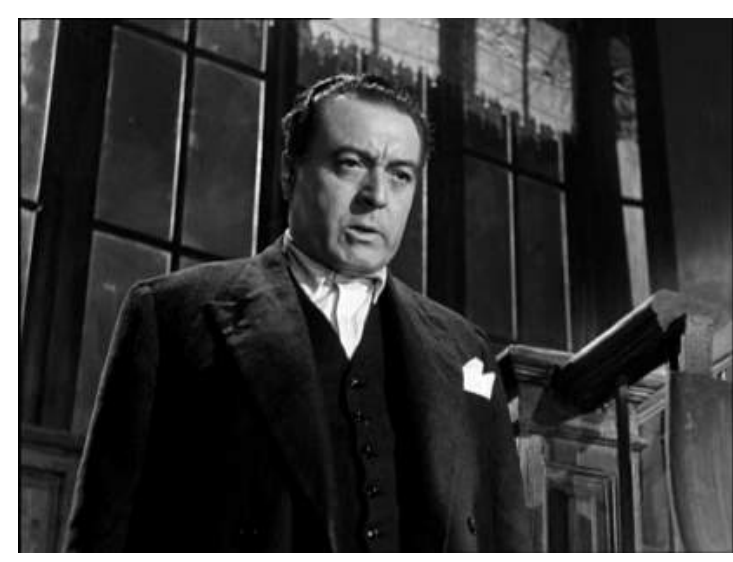

Figura 25a

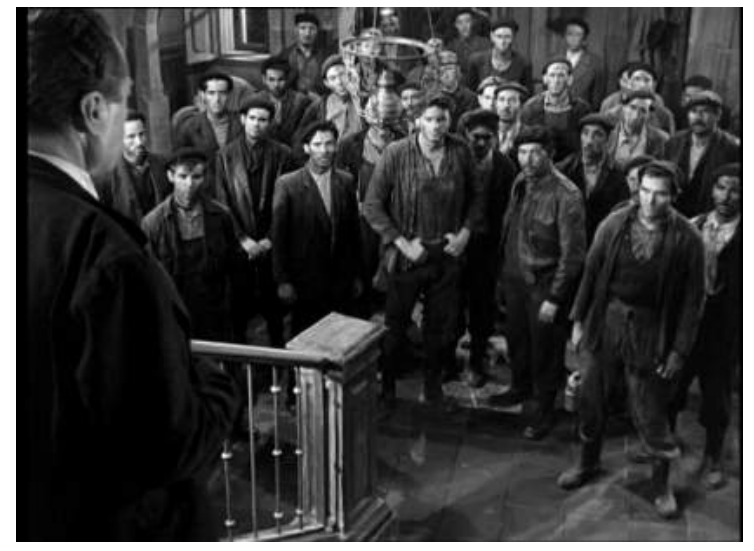

Figura 25b

Finalmente, ante la negativa de don César, Martín comunica la decisión de plante general mientras la cámara, en un movimiento de grúa, se emplaza en la posición de don César -ahora de espaldas- desde donde se escuchan las últimas palabras del grupo.

Un fundido encadenado traslada la línea de acción al ámbito de los niños y el cura Mendoza, que expresa su premonición sobre una próxima 
reconciliación de los dos estamentos. La sobreimpresión del plano del campanario de la iglesia da paso a la cuarta secuencia en que los mineros adelantan el inicio de la huelga. Es de noche, los vecinos de la aldea se dirigen a la misa de Navidad, mientras en casa de Martín los mineros se reúnen para planificar su acción, decidiendo entrar en la mina esa misma noche. Aprovechando que el resto de los vecinos sigue en la iglesia, los mineros emprenden el camino hacia su encierro. El dramatismo de la escena se subraya con la canción Adeste Fideles seguida del leitmotiv melódico asociado al grupo. La cámara se emplaza en el mismo punto alto de la plaza que anteriormente vio llegar al grupo para ahora verlo partir (fig. 26). Solo Margarita, la hija de Martín, es testigo de lo sucedido y avisa al padre Mendoza. Por sobreimpresión de imágenes la acción se traslada a casa de don César donde el padre Mendoza ha acudido con intención de mediar en el conflicto.

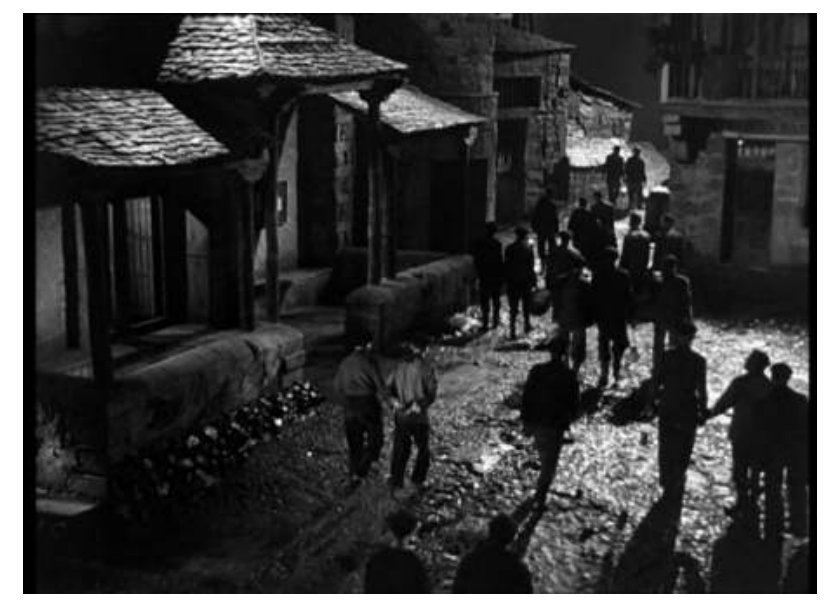

Figura 26

Tras una larga conversación en que don César no cede en su postura, el padre Mendoza decide actuar. Por corte seco la cuarta secuencia enlaza con la quinta que comprende el encierro de los trabajadores. Un plano abierto muestra al grupo de hombres en el interior de la mina con Martín dirigiéndose a los compañeros en calidad de líder (fig. 27). Llega el padre Mendoza, que antes de poder explicar su presencia en el lugar es golpeado por Martín, aunque finalmente será escuchado (fig. 28). A nivel diegético esta escena 
constituye un punto de inflexión puesto que la aceptación del cura por el estamento minero le reportará el rechazo de la clase dominante y con ello su reprobación como cura local en la línea principal del drama religioso.

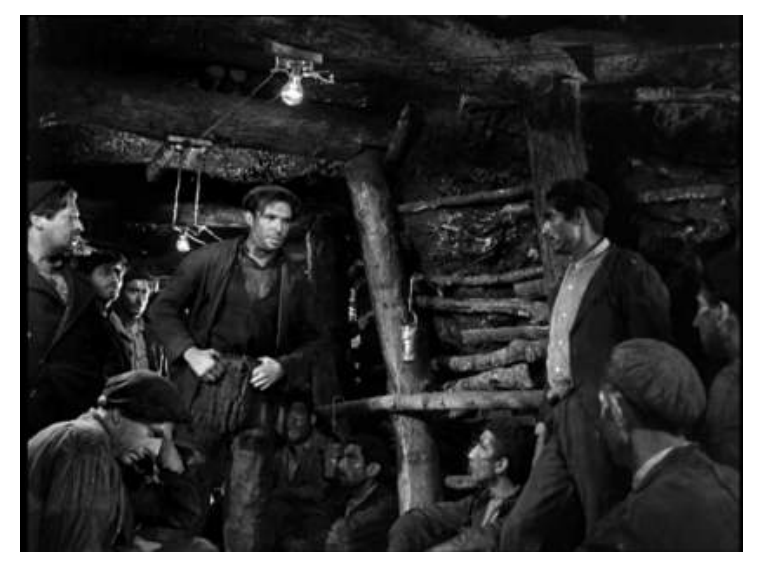

Figura 27

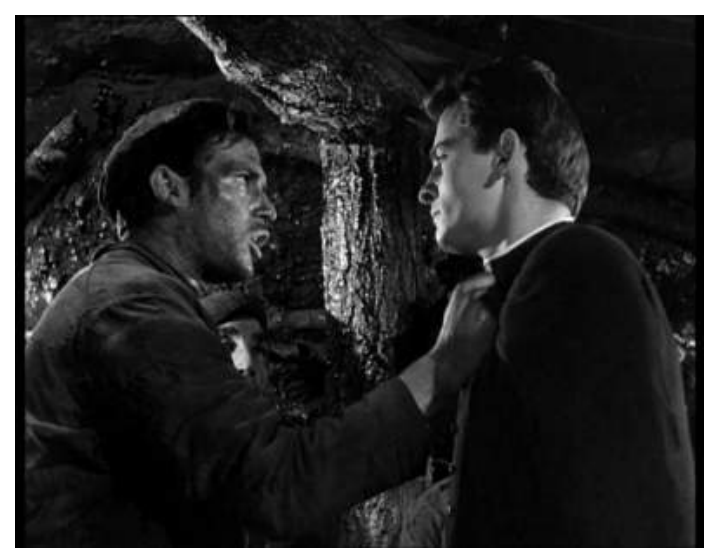

Figura 28

Cierra esta secuencia un plano medio del padre Mendoza sobre el que se sobreimprime un plano general de un grupo de mujeres sentadas en la bocamina anunciando la llegada de un nuevo día (fig. 29) y con él la cesión de Don César. La reconciliación social se escenifica mediante la presencia de los mineros en la misa diaria a la que también ha acudido el enviado de la diócesis para investigar la acción del cura Mendoza, cuyo devenir retoma el protagonismo argumental del filme.

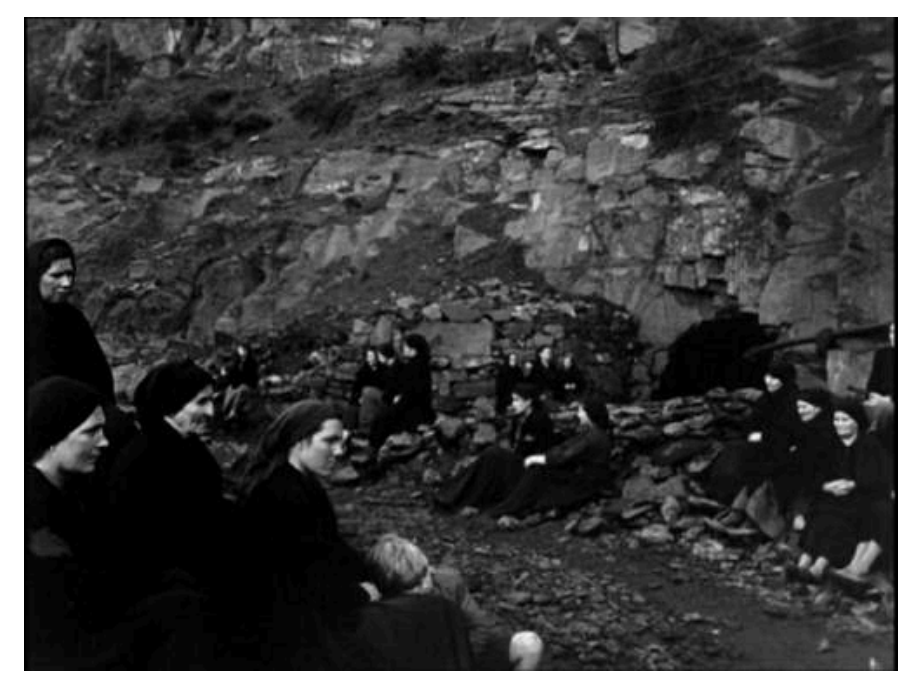

Figura 29 
Como ya sucediese en Amanecer en Puerta Oscura, en La guerra de Dios también se recurre a la sobreimpresión de un texto en la primera imagen del filme. En el rótulo se lee: "Al temple heroico de nuestras juventudes que lucharon por hacer posible la hermandad social de los hombres de España va dedicada esta película". Un mensaje que se lee desde la perspectiva del catolicismo militante de la década de los años cincuenta en que la película de Gil contribuía a enaltecer los valores católicos y la función de la iglesia como solución a los problemas sociales de los españoles.

Los textos críticos y promocionales que en su momento trataron La guerra de Dios son escasos. De existir se centran principalmente en los galardones que obtuvo la cinta, entre ellos la Concha de Oro a mejor película y mejor director en la primera edición del Festival de San Sebastián ${ }^{561}$, el premio de la Oficina Católica Internacional del Cine, OCIC, el León de San Marcos en la XIV Muestra de Venecia, 1953 y la medalla del Laurel de Oro de David O. Selznick en el Festival de Berlín, 1954. La línea general de los textos sobre la película de Forqué se centra en promocionar la obra doctrinal de la Iglesia católica. Un ejemplo es la crítica de José Bruno para Primer Plano ${ }^{562}$. "La Iglesia, en sus Estatutos, y ahora también en sus Encíclicas, procura la santa paz para todos los medios, y en esta nueva película, La guerra de Dios, se aboga por esa paz a todo trance, planteándonos en emocional relato el Gran Problema de nuestro tiempo". También llamado "la lucha más enconada de todos los siglos" al no haber "deseo de paz, porque los intereses [económicos] de los de arriba y los intereses de los que se colocan arriba de los de abajo no quieren la paz". De ahí que, como propone el filme, la única vía de solución sea la llegada del joven cura "para llevar luz y calor de Cielo a la entrada negra y dura de la mina [...] la guerra sorda, tremenda, irreductible, y que desgraciadamente no habrá de bastar a la mansedumbre dulcísima de

\footnotetext{
${ }^{561}$ Cabe tener en cuenta que en la primera edición del festival solo fueron premiadas producciones españolas. Hay un camino a la derecha de Francisco Rovira Beleta consiguió el galardón a mejor actriz y mejor actor y Carne de Horca de Ladislao Vadja fue premiada en el apartado de mejor ambientación y fotografía de Otello Martelli.

A partir de https://www.sansebastianfestival.com/1953/premios_y jurados/premios/1/46/es. [Consultado: 6 diciembre 2018].

${ }^{562}$ Primer Plano. Núm. 670.16 de agosto de 1953. Año XIII.
} 
la santa doctrina, que forzosamente habrá que hacer la más dolorosa de las guerras: La guerra de Dios ${ }^{563 " . ~}$

Los espacios rurales de La guerra de Dios son la mina y la aldea. De nuevo la elección de la mina no resulta fortuita pues como describe José Bruno simboliza el "infierno frío ${ }^{564 " ~ h a b i t a d o ~ p o r ~ l o s ~ m i n e r o s, ~ c a r a c t e r i z a d o s ~}$ de manera arquetípica como un grupo rudo y salvaje. Mientras que don César encarna el perfil del cacique despiadado. Dos arquetipos a su vez caracterizados por la falta de empatía hacia el otro por lo que necesitan la mediación de una tercera figura: el sacerdote, el único sujeto capacitado para el diálogo, la perseverancia y la comprensión. El recurso a la polarización de los caracteres sociales de la La guerra de Dios está destinado a ensalzar los atributos positivos de la figura del eclesiástico en el contexto de los acuerdos entre el régimen franquista con la Santa Sede. Por lo que el joven sacerdote fue visto como el "trasunto de un joven franquista modélico ${ }^{565}$ ".

La unión del cura Mendoza con los mineros huelguistas se produce cuando este, tras un diálogo infructuoso con don César, desciende a la mina. Esta acción ilustra la lectura que Primer Plano ofreció en su número 676 del filme como portador de:

"Un mensaje de espiritualidad que entra con su luz blanquísima y deslumbradora en el mundo negro y sucio de la mina de carbón, en la vida de unos hombres rudos que luchan para sacar sus tesoros de las entrañas de la tierra y que necesitan imperiosamente oír la voz que viene de lo alto, y que, entre el ruido de las máquinas y los gritos de los hombres que quieren adormecerlos, difícilmente pueden alcanzar".

\footnotetext{
${ }^{563}$ En otro texto también publicado en Primer Plano se localiza el filme dentro de la "lucha evangélica" que en parte justificó la sublevación militar, una cruzada, o "una guerra contra los que no quieren más guerra; en que, para apaciguamiento de los odios, se aspira a hermanar y no a separar". Primer Plano, 6 septiembre 1953. Núm. 673. Año XIII.

${ }_{564}$ El párrafo completo dice así: "Para los antiguos, el Infierno estaba en el centro de la Tierra, que respiraba fuego y azufre bíblicos por las bocas de sus volcanes. Concavidades infernales semejan las minas, negras y traicioneras, y para mayor parecido a los Avernos, el odio, predicado por el Mal, ha llevado a ellas las desesperaciones sociales, el pesimismo negro de la irredención, envenenando el trabajo y la vida, y total ruina y derrumbamiento para todos". Primer Plano 16 de agosto de 1953. Núm. 670. Año XIII.

${ }^{565}$ Pérez Gómez, 'La guerra de Dios'. En Pérez Perucha (ed). 1997: 331-333.
} 
De hecho la brutalidad del grupo minero es criticada por el cura como sucede en el momento que rinde cuentas ante el enviado del arzobispado, "No estoy con la violencia. Pero si por ser ellos violentos se les niega la razón cuando la tienen no estarán nunca de nuestro lado". Una afirmación que revela la consideración que el propio sacerdote tiene de si mismo, pues formando parte de 'los de arriba' es el único dispuesto a ofrecer la oportunidad de diálogo a 'los de abajo'.

En conclusión, el peso de la función propagandística y doctrinal de La guerra de Dios termina por transformar la línea social del filme que había surgido del "cuadro social [...] desolador en tierra calcinada por su naturaleza y por los rencores que ha llevado allá la política del buró; en que esa lucha se proyecta sobre toda la vida de un pueblo, incluso hasta en los inocentes niños ${ }^{566 " . ~ D e s d e ~ u n a ~ p e r s p e c t i v a ~ h i s t o r i o g r a ́ f i c a ~ L a ~ g u e r r a ~ d e ~ D i o s ~ e j e m p l i f i c a ~}$ las fórmulas del cine de los años cincuenta, coherente coherente con la trayectoria de su autor y productor a la vez que con el contexto políticoreligioso de la España de los años 50 de ahí la función evangelizadora ${ }^{567}$ que termina por asumir.

\subsection{La venganza, 1957, territorio de labranza}

El trabajo de temporero ha sido, y es, una actividad habitual en el medio rural donde los ciclos de los cultivos han condicionado el modo de vida del campesinado. La venganza, 1957, es el sexto ${ }^{568}$ filme de Juan Antonio Bardem en que aborda la cuestión rural a partir del fenómeno de la migración temporal de una cuadrilla de segadores ${ }^{569}$ andaluces a los trigales

\footnotetext{
${ }^{566}$ Ibídem.

${ }^{567}$ En cuanto que gozó del visto bueno del obispo-patriarca de Madrid en 1953, además de contar con la participación de sacerdotes de prestigio en tareas de asesoramiento en el guion como Ángel Sagarmínaga, con cargos de responsabilidad en la Iglesia española y Javier María Echenique, periodista, escritor y director de Fides Centro, federación de salas católicas de cine. Pérez (Coord.), 1997: 331-333.

${ }^{568}$ Los cinco films anteriores fueron Esa pareja feliz codirigida con Luis G. Berlanga, 1950; Cómicos, 1951; Felices Pascuas, 1953, Muerte de un ciclista, 1954 y Calle Mayor, 1955.

${ }^{569}$ En el apartado 7 de la Ficha Filmográfica publicada por Visor sus autores F. Pachecho y R. Bodegas recogen el siguiente dato: "Berlanga en San Sebastián dijo en el curso de
} 
castellanos. El proyecto se concibió en forma de coproducción con Italia ${ }^{570}$ con la participación de Manuel J. Goyanes para Suevia Films y Cesáreo González y VIDES, s.p.a. (Roma) y fue distribuida por la Metro Goldwyn Mayer $^{571}$. Contó con la presencia de Carmen Sevilla, Jorge Mistral y Raf Vallone en los papeles principales ${ }^{572}$. La coproducción y la participación de tres actores del llamado Star System garantizarían la trayectoria internacional del filme ${ }^{573}$. Lo cual, a su vez, reportó ciertas incongruencias, por ejemplo la cuota italiana $^{574}$ en el reparto de actores obligó al doblaje de los diálogos y la desaparición de las peculiaridades dialectales de las regiones de Andalucía y de Castilla. O la elección de los actores protagonistas, fue interpretada por parte de la crítica como el sometimiento a los dictámenes comerciales de la época, restando credibilidad a los personajes campesinos representados.

La atención de Bardem a los avatares del trabajo campesino hacen de La venganza una representación vivida del espacio rural como territorio de conflicto social. La perspectiva de Bardem se justifica en primera instancia atendiendo a su condición autoral y su militancia cultural, como ya se ha argumentado, que le llevó a participar de los debates sobre el devenir de un

Estudios Fílmicos que J. A. Bardem ya en el I.I.E.C había soñado hacer una película sobre la vida de los segadores. Esto hace suponer que cuando salió a rodarla ya tenía una idea muy sólida de lo que quería, y fue motivo de que la concepción de la película abarcase un cúmulo de detalles que motivaron su enorme duración". Núm. 2. 30 de noviembre de 1959.

${ }^{570}$ Circunstancia que fijó la aportación española en 5.220 .880 pesetas y la italiana en 2.237.523 pesetas, esto es el 37 y el $30 \%$, respectivamente. A lo que debe sumarse un aumento del presupuesto inicial en 6.970 .880 pesetas, según datos del expediente de la película del Archivo General de la Administración.

${ }^{571}$ En el cuaderno de venta de la película Enrique Alarcón, el jefe de decorados, era presentado a partir de su vínculo personal con la región castellana. En palabras del propio Alarcón, "He nacido en la Mancha. Me he criado bajo ese cielo inmenso, pisando el polvo y los terrones de la llanura. Conozco la vida del campesino, sus problemas, el sol en la nuca y el fresco tras los tapiales blancos de cal y cal".

572 Cuyos estatus de reconocidas estrellas del celuloide en los años 50 les reportaron unos ingresos de 1.200 .000 pesetas a cada uno. Carmen Sevilla, consolidada actriz a nivel nacional, se había especializado en el género folklórico con películas como La Revoltosa, o las mencionadas Un caballero andaluz y La pícara molinera. Jorge Mistral, con una prolífera carrera en España y México, había participado en Locura de Amor, Pequeñeces o La duquesa de Benamejí. Y por su parte Raf Vallone, actor italiano con proyección europea, contaba entre sus películas Los ojos dejan huella, 1952, Riso amaro, 1949, o Teresa Raquin, 1953.

${ }^{573}$ La repercusión de La venganza en el momento de su estreno la constatan el premio FIPRESCI en la $11^{\circ}$ edición del Festival de Cannes y la nominación a los premios Oscar en la categoría de película de habla no inglesa, en la edición 31, ambos en el año 1958.

${ }^{574}$ Raf Vallone en el papel de Luis, el Torcido. María Zanoli como la madre y Arnaldo Foà como el tendero. 
cine nacional acorde al resto de cinematografías. Bardem también militaba en el Partido Comunista de España que justo en estos años emprendía una nueva estrategia programática de reconciliación de los dos bandos en que había quedado dividida España. La venganza ponía en imágenes la concatenación de episodios de solidaridad campesina lo que la convertía en vehículo para transmitir el mensaje del PCE en un contexto político y económico de transformación, como se ha analizado.

Si bien, el excepcional perfil del realizador no estuvo exento de lidiar con una serie de premisas estilísticas, condicionantes de producción y reprobaciones censoras que condicionarían el resultado final de $\mathrm{La}$ venganza. Cabe señalar dos consideraciones previas al análisis fímico. La primera se refiere al arranque del filme a partir de las formulaciones propias del género del drama rural constituyendo el preámbulo que dará paso al desarrollo de la línea social. Y la segunda constituye la hipótesis sobre la imposibilidad de hablar de crítica social en La venganza debido a que todos los esfuerzos van dirigidos a armar la dimensión épica de los personajes en su condición de supervivientes que terminará por estrechar los lazos entre los miembros del mismo estamento, como metáfora de la sociedad española del momento.

\subsubsection{El drama rural inicial}

La acción de La venganza empieza justo cuando Juan -Jorge Mistral- se dispone a volver a casa después de diez años en presidio. Allí le espera su hermana, Andrea -Carmen Sevilla, su único pariente e instigadora del odio hacia la familia de los Casa Vieja por haber inculpado a Juan de un crimen que no cometió. Los dos hermanos traman un plan que consiste en unirse a la cuadrilla de segadores de Luis, el Torcido -Raf Vallone, miembro de la familia rival, para perpetrar su venganza. Este episodio inicia la línea argumental del drama rural distinguiendo los elementos que González 
Requena enumera en la identificación de este género ${ }^{575}$. El primero, el odio atávico que, en este caso, Andrea como 'la madre' de los Casa Vieja se afanan en avivar. Un sentimiento encarnado en los arquetipos femeninos que, desde los confines de sus hogares, infunden al resto de miembros masculinos a pesar de que ellos se muestran dispuestos a superar. Este hecho responde a los preceptos perniciosos con que son concebidos los arquetipos femeninos del drama rural, como ha analizado Carmen Arocena a propósito de Condenados ${ }^{576}$. Aunque a diferencia de los personajes de Aurelia, Cruz o Nela a las que se les ha negado la mirada e impuesto una carga negativa primigenia, las mujeres de La venganza son sujetos activos que conscientemente infunden odio con el objetivo de perpetuar la división de las dos familias. Una obstinación que tiene que ver con el segundo factor del drama rural, la existencia de "un código moral y de costumbres rígido e inflexible cuya violación -real o aparente- es acusada socialmente como la transgresión de un tabú que amenaza al conjunto social ${ }^{577 ", ~ e s t e ~ e s ~ e l ~ n u ́ c l e o ~}$ familiar de los Casa Vieja, una familia venida a menos para la cual Andrea constituye la amenaza. El carácter pernicioso de este personaje hace que funcione como agente que expone la base de "parentesco y el sentimiento de pertenencia de los miembros contenidos" en el núcleo familiar de los Casa Vieja, a su vez regido por el "cierre simbólico de la mentalidad campesina que lo convierte todo en un enfrentamiento permanente entre la comunidad y el exterior $^{578 " . ~ A d e m a ́ s ~ l a ~ c a r a c t e r i z a c i o ́ n ~ d e l ~ p e r s o n a j e ~ d e ~ A n d r e a, ~ e n c a r n a d o ~}$ por una jovial Carmen Sevilla, se sitúa en la línea del reduccionismo sexual al que también fueron expuestas el resto de personajes femeninos de dramas rurales analizados en el capítulo anterior.

\footnotetext{
${ }^{575}$ Cabe recordar la serie de elementos que Requena identifica en el género cinematográfico del drama rural herencia del ámbito teatral. El primero de ellos se debe a la existencia de "un código moral y de costumbres rígido e inflexible" fundamento de la comunidad social cuyo cumplimiento le otorga identidad. $Y$ el segundo tiene que ver con la presencia del odio "que sustenta y genera las agresiones de las fuerzas narrativas en conflicto". Aguilar, 1988: 17.

${ }_{576}^{5}$ Arocena, 2010.

577 Ibídem.

${ }^{578}$ Alonso et alii, 1991: 37.
} 
El otro personaje femenino de La venganza es la madre ${ }^{579}$ de los Casa Vieja- interpretada por la actriz italiana María Zanoli, se caracteriza con ropajes de color negro que la cubren por entero, un perfil acorde a las vestimentas de las mujeres rurales de la primera mitad del siglo XX. Su aparición se reduce a dos ocasiones en el preámbulo del drama. Las interpelaciones de la mujer refuerzan el significado de su presencia como imagen del inmovilismo que apela al pasado. En la primera escena la mujer insiste al hijo: "No quiero que olvides, tienes que acordarte siempre. Nadie debe olvidar lo que pasó", a lo que este, desde la predisposición al progreso, le reprocha el peligro que conlleva alimentar el odio entre familias. Ante la insistencia de 'la madre' el hijo responde: "Usted está siempre aquí, encerrada entre estas cuatro paredes, en esta casa que se viene abajo. Yo no, yo tengo que estar fuera con los demás, trabajando con todos".

El ámbito doméstico de La venganza es un espacio exclusivamente femenino corrompido por el aislamiento social del propio inmueble que revierte sobre la madre de los Casa Vieja y Andrea. Una circunstancia que explica la determinación con la que 'la madre' se aferra al pasado como aquel estadio de bonanza económica y, ligado a ello, de bienestar familiar. En la segunda escena en que aparece esta permanece sentada en un segundo plano y en silencio mientras Andrea y Juan debaten con Luis, el Torcido unirse a la cuadrilla. Acordada la colaboración y solos madre e hijo, éste busca su beneplácito justificando la urgencia del dinero de la siega para mantener el hogar, a lo que la madre se limita a exclamar: “¿Y ella?" refiriéndose a Andrea ${ }^{580}$. Narrativamente, la colaboración prevé un acercamiento de las familias, materializado en la evolución del personaje de

\footnotetext{
${ }^{579}$ De hecho existe un tercer personaje femenino interpretado por Conchita Bautista en el papel de cantante de un circo ambulante y que inicia un breve cortejo con Pablo, el Tinorio. La presencia de este personaje se limita a una escena de menos de un minuto en que actúa en solitario ante los vecinos de una localidad y dos escenas breves sin diálogo. No obstante, y según la información de diferentes escritos que dan cuenta de la reducción de metraje que sufrió La venganza, esta línea argumental secundaria quedó afectada por dicho recorte lo que explica su falta de desarrollo.

580 Otro aspecto destacado de la concepción de los arquetipos femeninos de La venganza es la falta de solidaridad entre mujeres. Es más, la desconfianza con que 'la madre' percibe a Andrea entronca con la falta de empatía de las mujeres de Sierra maldita hacia Cruz o de Marcela en Viento del Norte. Todas ellas son percibidas como la amenaza a la estabilidad del núcleo social que personifican las mujeres mayores, incluso más allá de una posible unión para afrontar su situación marginal en los contextos patriarcales que habitan.
} 
Andrea del desprecio inicial a una progresiva estima hacia Luis, el Torcido. De ahí que la exclamación de la madre se entienda como premonición de la futura reconciliación y, desde la perspectiva de la mujer, del fin de la pretérita supremacía de los Casa Vieja.

Cabe añadir una última presencia femenina en la línea en que se conciben los arquetipos femeninos de La venganza. Se trata de la mujer del tercer hermano de los Casa Vieja, introducida en la diégesis por alusiones verbales fundamentando el preámbulo narrativo. Se sugiere que los entresijos amorosos de esta con el segundo hermano a la vez que con Juan habrían motivado el crimen pasional por el que este último fue encarcelado. Bardem carga con la culpa-origen del drama rural a este personaje del que no se tienen más datos que las consecuencias de su vida sentimental.

Retomando el personaje de Andrea, ajena al atavismo característico de 'la madre' y también a la culpa de la mujer del hermano de los Casa Vieja, carga con el sentido dramático que Bardem confiere a la condición femenina. Un hecho que diegéticamente subraya la propia Andrea en conversación con Luis, el Torcido. Cuando este le insiste en superar el rencor que los separa ella responde:

"Dormir es bueno, pero de día, de día pienso, veo cosas, me acuerdo del miedo, del hambre, de la pena. $Y$ os veo, vosotros que habéis tenido la culpa. Vosotros, tú. No es bueno vivir así, no es bueno. A veces me digo si no es mejor olvidar, olvidarlo todo. $Y$ no puedo, no puedo. Estáis ahí delante tu gente y tú y tengo que recordar y odiarte".

Sin embargo, la caracterización de Andrea como una mujer joven ajena a los sucesos del pasado le ofrece la posibilidad de superar el enfrentamiento y que Bardem resuelve en clave moralizante sintetizada en la exclamación del personaje al final del metraje: "La tierra es grande, cabemos todos juntos". La evolución sentimental del personaje la liberará de la carga negativa exponiéndola previamente a un episodio de agresión sexual. Este es un episodio puntual del relato fílmico carente de intención crítica como también 
sucede en Sierra maldita. En ambos casos las protagonistas son agredidas por el antagonista aprovechando el distanciamiento respecto al confort de sus hogares. Andrea ha ido a la tienda a comprar comida para la cuadrilla. El marido de Cruz la deja sola en el campamento de carboneros para bajar al pueblo, por lo que ambos personajes son víctimas del aislamiento del espacio rural, el cual a su vez, funciona como detonante de las pulsiones primitivas del género masculino constatadas, fílmicamente, en forma de agresión sexual. Los dos episodios contienen una gran carga de violencia física que en el caso de La venganza se resuelve en clave de solidaridad del grupo de segadores. En conclusión el tratamiento de este episodio de agresión sexual hacia la mujer se construye en la línea del resto de conflictos a los que se enfrenta el grupo protagonista en que la crítica social queda supeditada a la transmisión de la alegoría de solidaridad.

\subsubsection{La deriva social final}

La dimensión social de La venganza surge de la voluntad de Juan Antonio Bardem por representar el espacio rural en calidad de territorio vivo del que surgen una serie de conflictos. Esta segunda línea argumental se construye en torno a la migración de las cuadrillas de temporeros a Castilla para la siega del trigo. Un fenómeno descrito por la voz en off inicial:

"Todos los años cuando el trigo está maduro llegan hasta las dos Castillas hombres de Galicia, Extremadura, Cuenca, de las tierras altas de Andalucía. Es una emigración temporal y lógica, vieja como nuestra tierra o nuestro pan que se repite todos los años puntualmente. El trigo es mucho y los brazos pocos, por eso las gentes de tierras de pasto, olivar o viña, donde la labor en esta época es nula, vienen a la llanura amarilla, horizontal e interminable y emplean su esfuerzo en uno de los más nobles y antiguos oficios de la tierra. Son los segadores. Vienen hombres y mujeres y chicos en este viaje de ida y vuelta por la meseta bajo el cielo azul. Estas cuadrillas de segadores cumplen un rito antiguo de trabajo y camino y se hermanan a los hombres y las mujeres de las risaias del Po, a la gente valenciana que sube hasta las tierras de la Camalga, a los píquers que 
llegan desde Oklahoma a la California dorada, a los espaldas mojadas mejicanos que atraviesan el Río Grande.

Este filme pretende contar pura y simplemente los trabajos y los días de una cuadrilla de segadores".

El relato del narrador se acompaña visualmente de una panorámica horizontal que da cuenta de la vastedad de los campos de Castilla (fig.30).

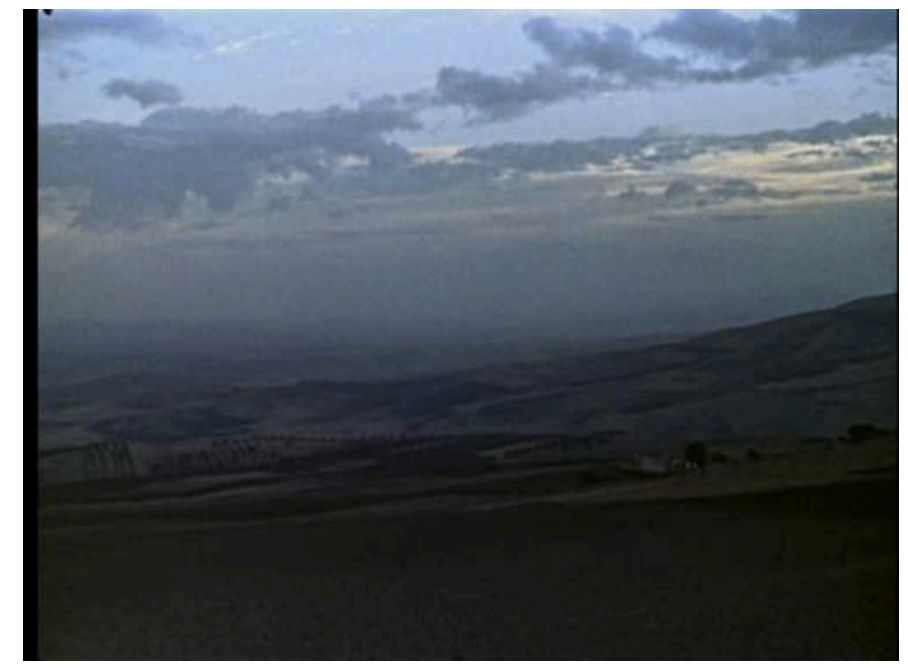

Figura 30

El detalle con que se concibe esta vista del paisaje natural establece el grado de aproximación con que Bardem pretende testimoniar el campo español. De hecho este encuadre se repite posteriormente junto a un gran número de planos generales de los trigales siendo trabajados.

La fotografía, a cargo de Mario Pacheco, discurre en una paleta de colores pálidos -ocre, amarillo pajizo, azul claro, violetas y blancos- de gran plasticidad. Como novedad se empleó el Eastmancolor cuya inversión fue explotada en la promoción de la película. Formal y discursivamente los planos de La venganza remiten a la obra de Jean-François Millet cuyo modo de entender el género del paisaje le llevó a observar y representar a los campesinos y sus modos de vida desde su faceta de trabajadores cansados, no sin extraer "la bellesa [que] estava en l'expressió mateixa, i fer bells o 
elegants els pagesos era falsejar i afeblir la pintura ${ }^{581 "}$. Las intenciones de Millet, como ya se ha comentado, resultaron innovadoras en el seno de la pintura de paisaje de la escuela de Barbizon y el just milieu francés o el entorno inglés de Constable del siglo XIX. En referencia concreta a El aventador la profesora Gracia argumenta que su intención era la de resaltar:

"La grandesa heroica [...] Però a més d'aquesta potent força, Millet hi va introduir detalls rudes que allunyaven la figura de la tradició bucòlica. L'expressió brutalitzada, el dibuix dels dits en forma d'urpes que agafen la cistella, el tractament dels socs, els pedaços als pantalons: tot això aportava una visió de la pagesia molt allunyada de les idealitzacions precedents ${ }^{582,}$.

Ambas obras, a pesar de la distancia temporal, comparten el hecho de haber sufrido censura debido a la osadías de los tratamiento formales del estamento campesino. Cineasta y pintor concibieron sus arquetipos rurales bajo el prisma de la epicidad, una elección que en el caso fílmico terminará por limitar el desarrollo psicológico de los personajes en aras de una función arquetípica, lo que se entiende como un distanciamiento del rigor testimonial pretendido en los títulos iniciales.

\subsubsection{Análisis formal de los episodios sociales}

El inicio de la línea social tiene lugar una vez presentados los personajes en el preámbulo del drama rural. Formalmente el enlace se produce mediante un fundido encadenado que sitúa a los protagonistas en el inicio de su periplo. Un plano general introduce la nueva localización, los campos de Castilla. Constituido en primer término por tres segadores ablentando hacinas de trigo mientras el grupo entra por el lado izquierdo cargando sus bártulos (fig. 31). A continuación, en una plaza indefinida Luis, el Torcido negocia el

\footnotetext{
${ }^{581}$ Gracia, 2000: 131.

582 Ibídem. "La grandeza heroica [...] Pero además de esta potente fuerza, Millet introdujo detalles rudos que alejaban la figura de la tradición bucólica. La expresión brutalizada, el dibujo de los dedos en forma de garras que sostienen los cestos, el tratamiento de los zuecos, los pedazos en los pantalones: todo esto aportaba una visión del campesinado muy alejada de las idealizaciones precedentes". Traducción de la autora.
} 
primer contrato de trabajo. El buen comienzo de la cuadrilla se enfatiza formalmente con el uso de la banda musical, dando paso por corte seco a un plano cenital muy abierto de los trigales en que ha empezado a trabajar la cuadrilla (fig. 32). Una segunda línea melódica de guitarra y instrumentos de viento funciona como subrayado de la acción de la siega. A partir de este instante se suceden una serie de trifulcas menores, entre ellas el ajuste del ritmo de trabajo de los miembros de la cuadrilla, el accidente con la hoz de Tinorio o el encuentro con otra cuadrilla de segadores que desembocará en una breve batalla dialectal de tono cómico ${ }^{583}$. Además de otros conflictos mayores que pondrán de manifiesto las hostilidades del trabajo en el entorno rural. Los acontecimientos de estos episodios conforman la línea social del filme que identifica al estamento campesino a partir de los avatares derivados de la cotidianidad laboral.

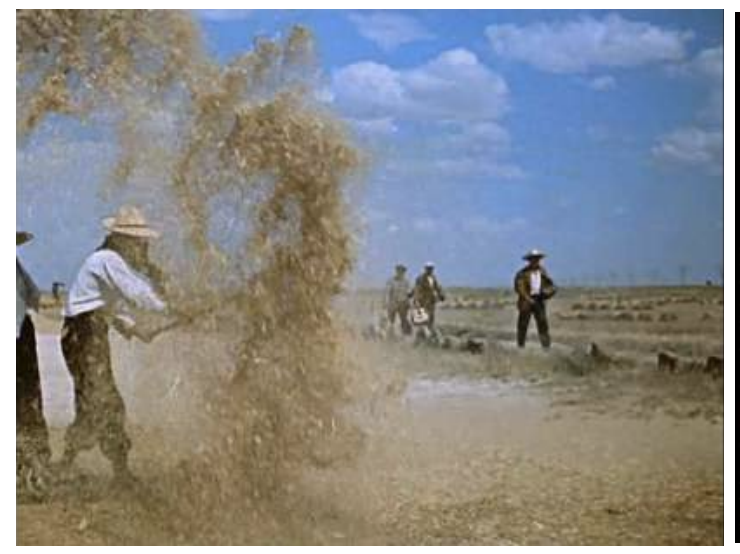

Figura 31

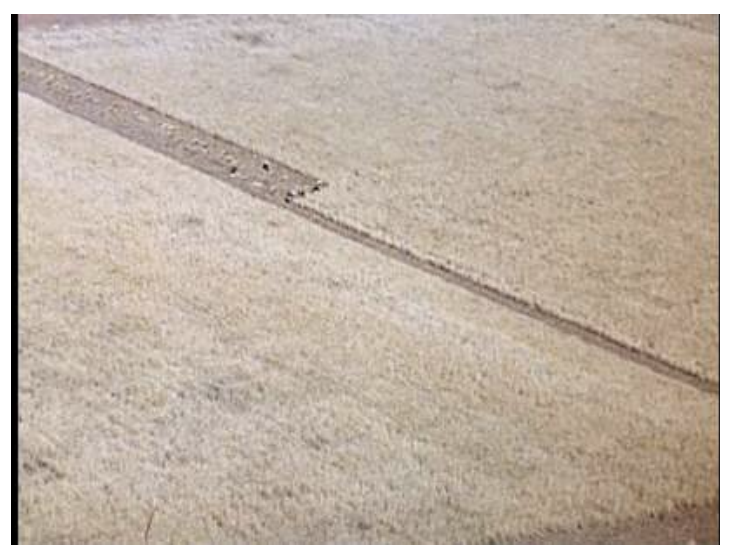

Figura 32

El primero de los conflictos recoge un episodio de huelga protagonizado por los segadores de uno de los pueblos a los que llega la cuadrilla la cual, por desconocimiento, ha aceptado el trabajo a destajo ofrecido por el mayoral de la finca La Moraña. La presencia del grupo desestabiliza las

\footnotetext{
${ }^{583}$ El duelo retórico entre cuadrillas es un hecho real. En la provincia de Murcia se conoce como "trovo" apunta el crítico Lamet. Pérez Lozano opina que "Es una incursión de J. A. Bardem en lo lírico, aunque sea en lo lírico-bufo, que no entona dentro de la dimensión trágica en que está el resto de la obra". Film Ideal. Núm. 29. Marzo de 1959. En la misma línea la ficha filmográfica de Visor hace referencia al duelo verbal como un episodio que "desentona, emparentando [La venganza] con la zarzuela tanto como los coros. Núm. 2. 30 de noviembre de 1959.
} 
negociaciones justo en el momento de mayor tensión en que se espera resolver a favor de los huelguistas.

Formalmente la secuencia se desarrolla en dos partes, una primera de conocimiento de lo sucedido con la visita de Juan al pueblo donde se está produciendo el plante general. Y una segunda de reacción solidaria del grupo protagonista. La primera parte consta de tres escenas: el encuentro de Juan con los vecinos sublevados, la visita al médico y su salida del pueblo. La segunda escena supone la revelación verbal de lo sucedido por parte del médico, siendo la primera y la tercera -donde Juan se enfrenta a los vecinos huelguistas- las más ricas formalmente.

A su llegada al pueblo Juan es recibido por dos mujeres que le dan indicaciones. El protagonista se adentra en las calles del pueblo observando un ambiente tenso y hostil a medida que va encontrándose con los vecinos. La planificación de esta secuencia surge en base al montaje del plano contraplano de Juan, acompañado por un travelling, y de la masa de vecinos que, inmóviles, marcan con la mirada el paso del protagonista (fig. 33a y b). La banda sonora solamente recoge los pasos del protagonista y los toques del campanario que enfatizan el dramatismo de la escena. Finalmente Juan toma aliento para emprender un tramo muy concurrido en que quedará atrapado en el cerco que han formado los vecinos (fig. 33c).

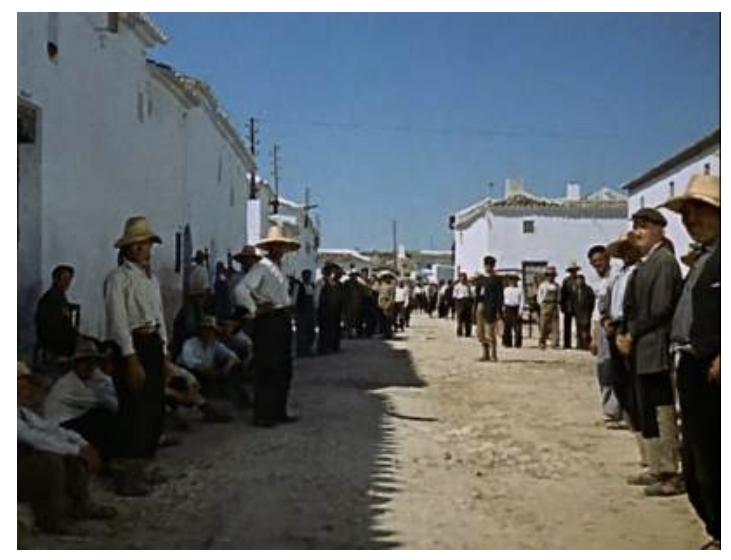

Figura 33a

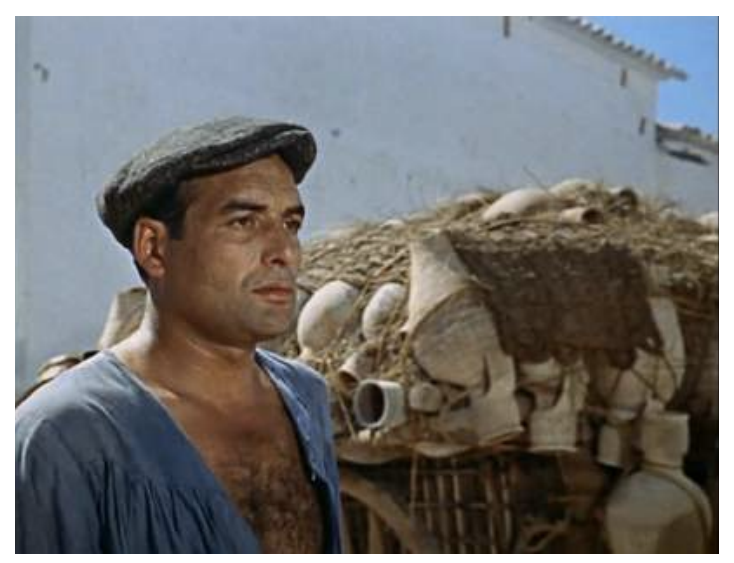

Figura 33b 


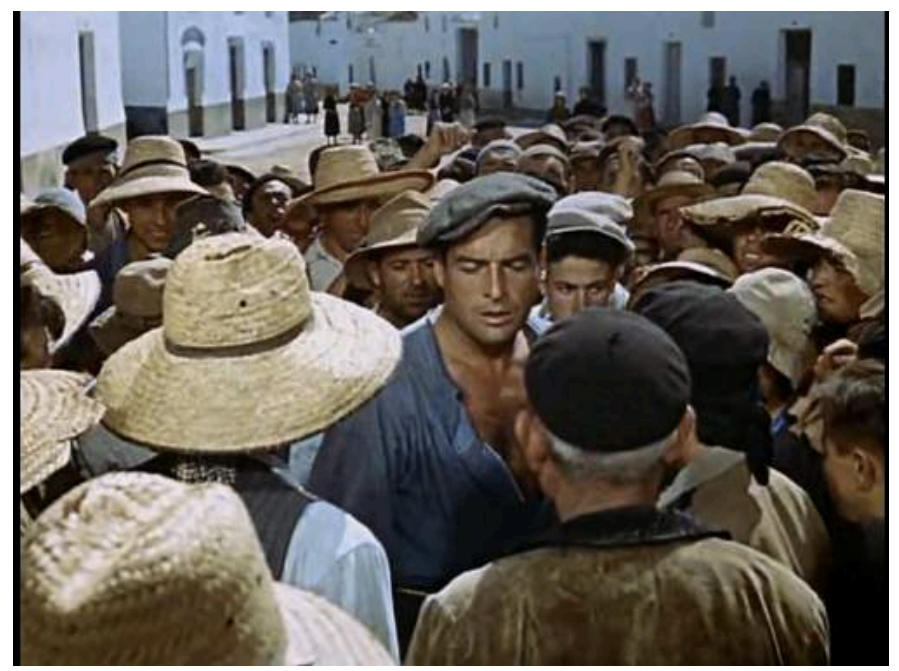

Figura 33c

El hombre pide paso repetidamente mientras es increpado por la muchedumbre y obligado a dar explicaciones hasta que una pareja de la Guardia Civil acude en su auxilio. Tras la visita al médico, Juan emprende la salida del pueblo ya conocedor de lo sucedido. Desde un ángulo picado la cámara recoge la despedida del protagonista en el mismo lugar donde anteriormente había sido increpado y ahora es insultado sin hostigamiento físico (fig. 34).

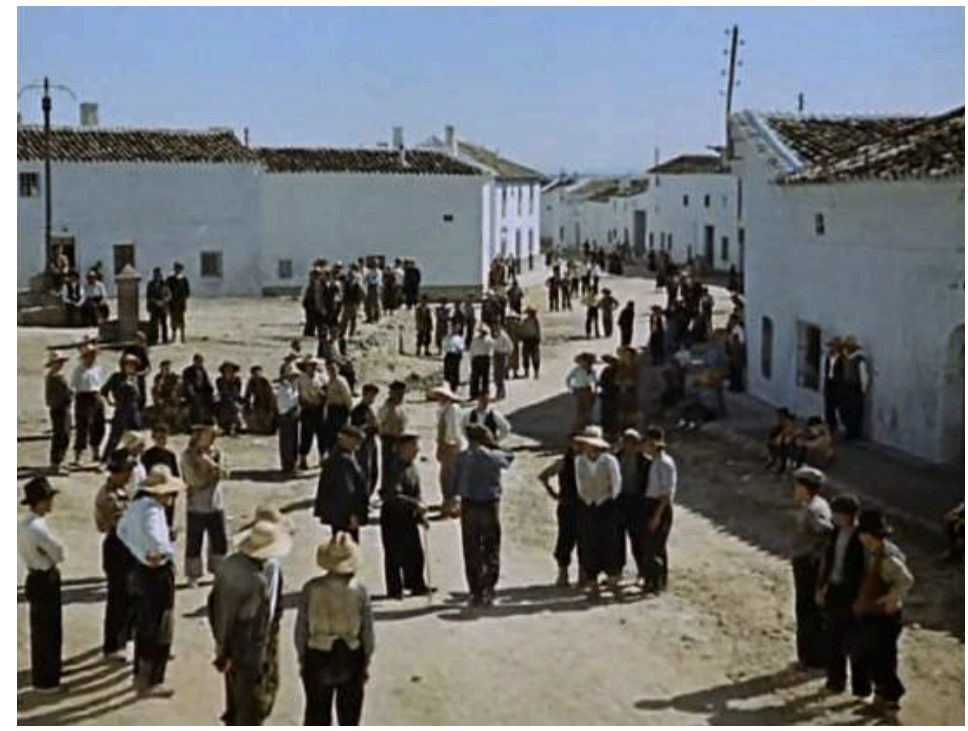

Figura 34 
Narrativamente, los hombres del pueblo acusan a Juan, y por extensión al resto de la cuadrilla, de robarles el pan, de ser unos "vendidos y unos ladrones". La escena termina por corte seco dando paso a la segunda parte de la secuencia en que, de vuelta en los campos, Juan y Andrea deciden solidarizarse con los vecinos del pueblo y abandonan la cuadrilla. El resto del grupo se resiste a desaprovechar la oportunidad de trabajo, pero al ser reprendidos con brutalidad por el mayoral de la finca terminan por unirse a la reivindicación general consiguiendo con ello el contrato a jornal para todos los segadores de la zona.

Formalmente la victoria de los segadores discurre en forma de celebración. Una panorámica horizontal recorre la inmensidad de los trigales castellanos siendo trabajados por un gran número de cuadrillas (fig.35).

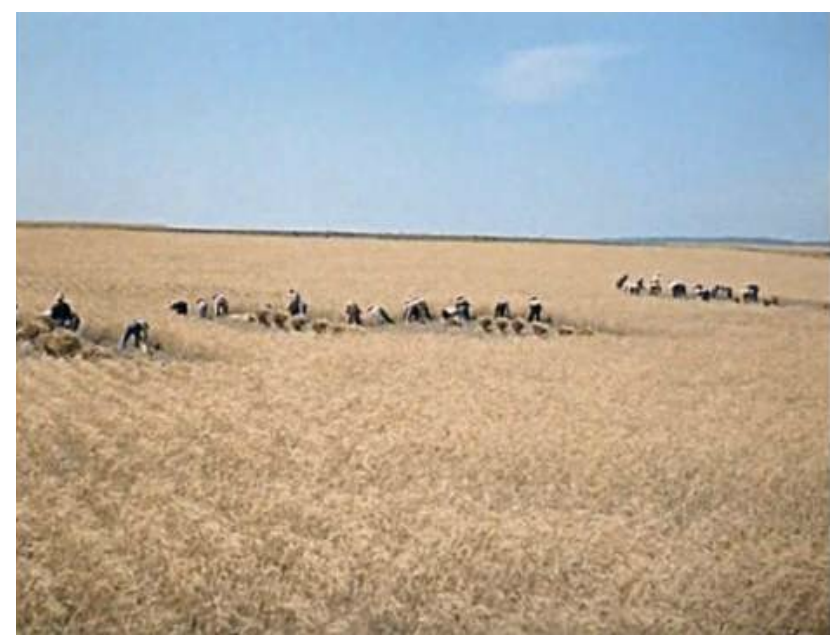

Figura 35

La escena, rodada en los trigales de Manzanares, se llamó "plano de la gran sinfonía ${ }^{584 "}$ y en ella participaron un total de diez cuadrillas de catorce segadores oriundos de La Membrilla, además del grupo protagonista. El canto de los coros subraya el sentido de hermandad entre trabajadores del campo castellano sellado, diegétiamente, con la sonrisa de Andrea a Luis (fig.36a y b). En este instante convergen la línea dramática y la línea social.

\footnotetext{
${ }^{584}$ En el 'Diario del rodaje' de La venganza escrito por Luciano G. Egido, ayudante de dirección se encuentra la descripción detallada de las cuestiones técnicas y de logística del rodaje de la escena. En Cinema Universitario. Núm. 8. Diciembre de 1958.
} 


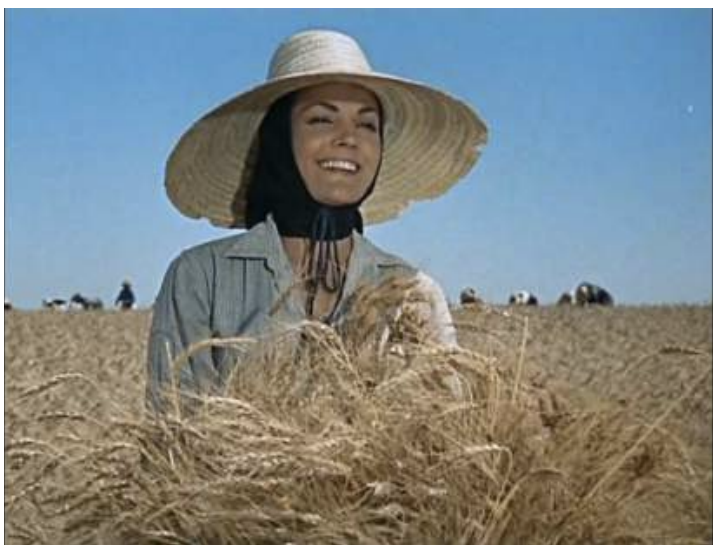

Figura 36a

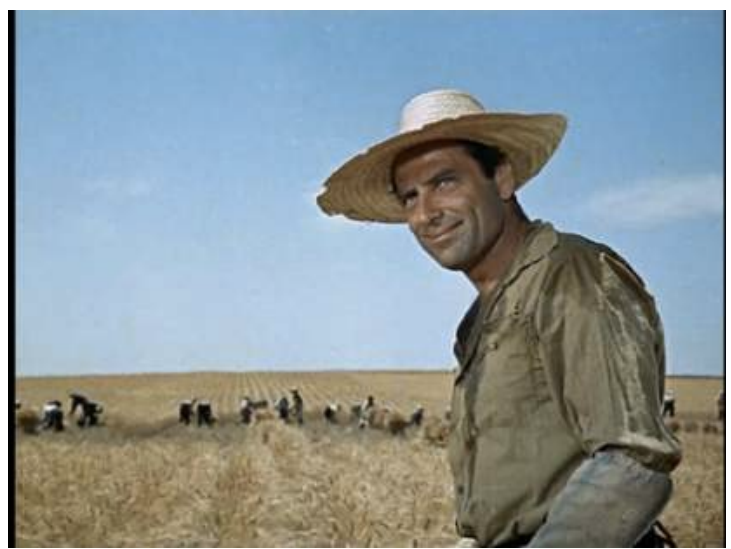

Figura 36b

La segunda secuencia de la línea social de La venganza comprende el incendio de las hacinas de trigo del pueblo donde la cuadrilla pasa la noche. Esta secuencia, de gran riqueza técnica se divide en dos partes, una primera de llamada y de sofoco de las llamas y una segunda de lamento ante la desolación del fuego.

Una escena introductoria muestra a los vecinos reunidos en un ambiente festivo. Cuando ya han regresado a sus casas se inicia la alerta de fuego en el lugar donde se almacenan los haces de trigo. A partir de este momento se suceden planos de corta duración de multitud de gente corriendo en la dirección del fuego, otros de vecinos asomándose a las ventanas de sus casas, de animales corriendo despavoridos y de vecinos atizando los montones de trigo u organizándose en columna para transportar cubos de agua (fig.37a y b).

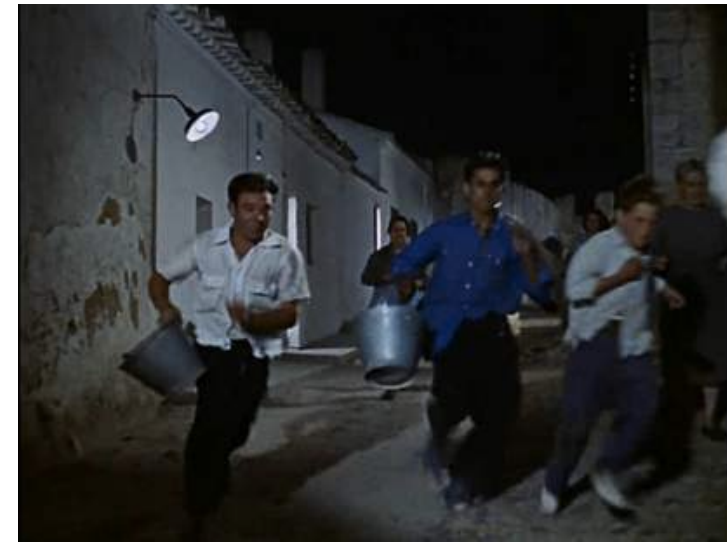

Figura 37a

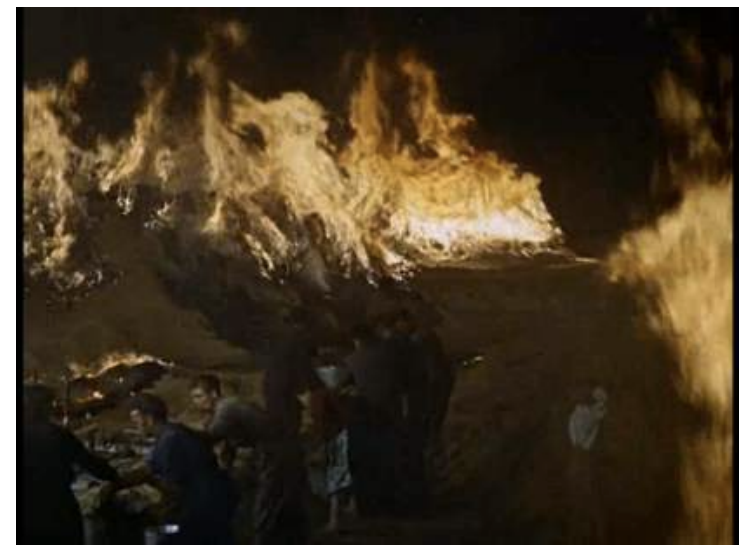

Figura 37b 
El ritmo de montaje se acelera para conformar la sensación dramática de la secuencia hasta que, ante la fuerza de las llamas, los vecinos desisten en su empeño y el ritmo del montaje decrece recreándose la cámara en planos detalle de los rostros de las gentes (fig.38a, b y c). Niños llorando, mujeres rezando, familias con la mirada fija en las llamas y, entre ellos, la cuadrilla protagonista que ha colaborado en el intento de extinción. Los planos detalle de las gentes se entremezclan con otros de las llamas consumiendo carretas y montones de trigo (fig. 38d). Formalmente el carácter dramático de la escena se sustenta en la acción de los personajes en los cambios de ritmo del montaje y en la presencia de una línea melódica instrumental.

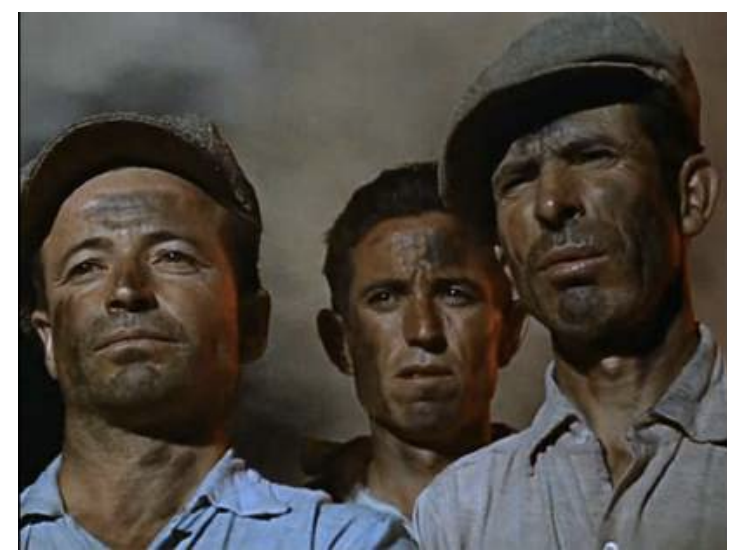

Figura 38a

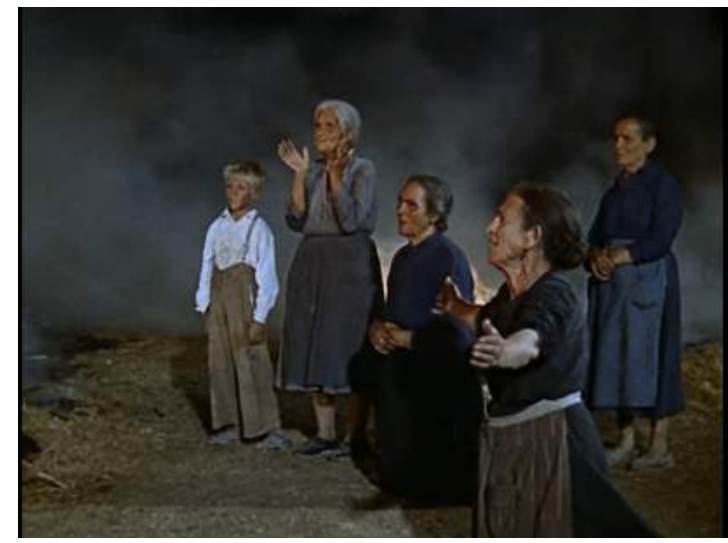

Figura 38c

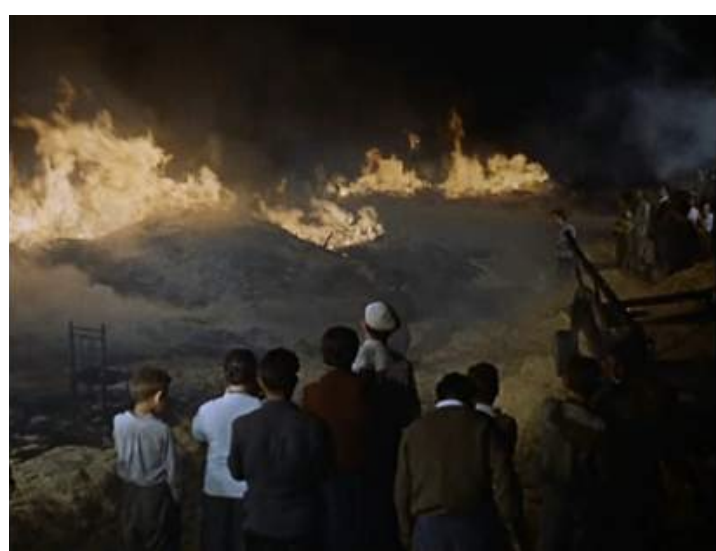

Figura 38b

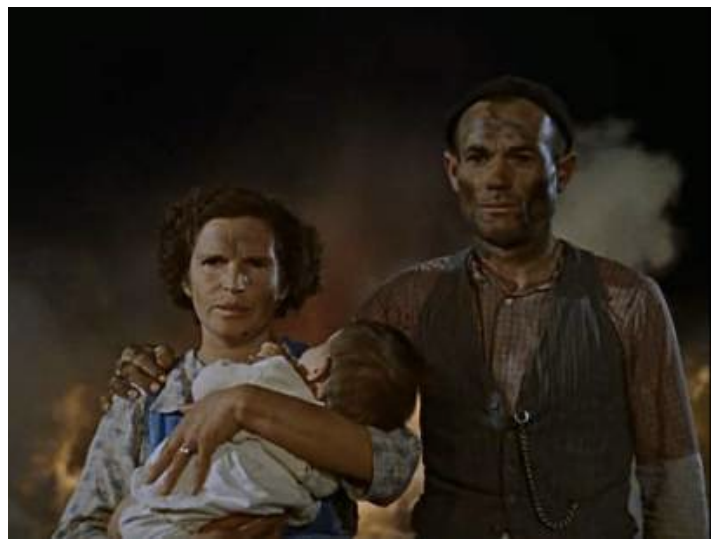

Figura 38d 
El tercer problema del campo español representado en La venganza se encuentra en el la secuencia de la última siega de la temporada: la tecnificación del campo y la consecuente suplencia de la mano de obra. Narrativamente este episodio sucede cuando Santiago, el Viejo, vislumbra una maquina cosechadora, precisamente, en el único campo que falta por segar. Hoz en mano el hombre se dirige al encuentro de la maquina resultando herido. La escena se elabora a partir de un crescendo dramático con la aceleración del ritmo del montaje del plano contraplano (fig. 39a y b), basado en primeros planos del rostro del hombre y otros generales de la máquina avanzando hasta producirse el choque quijotesco en que Santiago, el Viejo queda atrapado en el brazo metálico de la cosechadora (fig.39c).

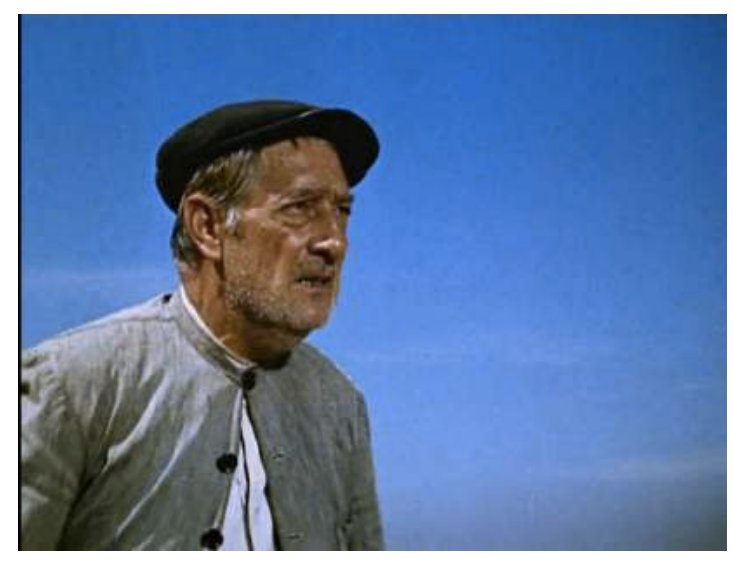

Figura 39a

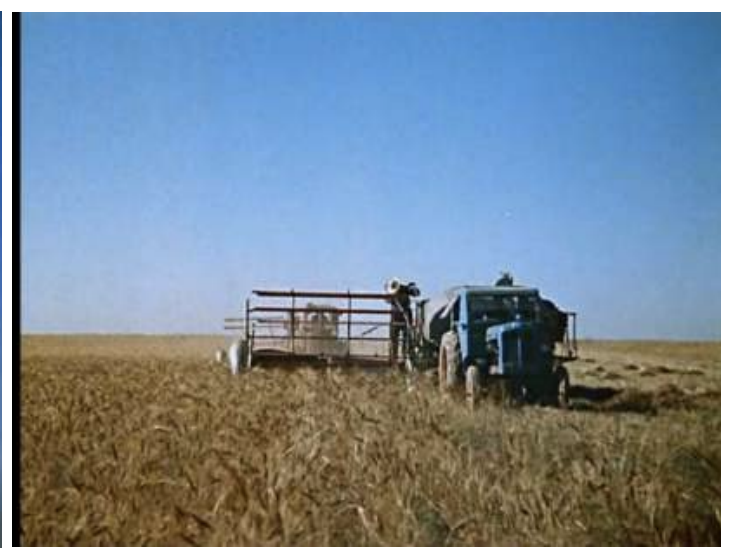

Figura 39b

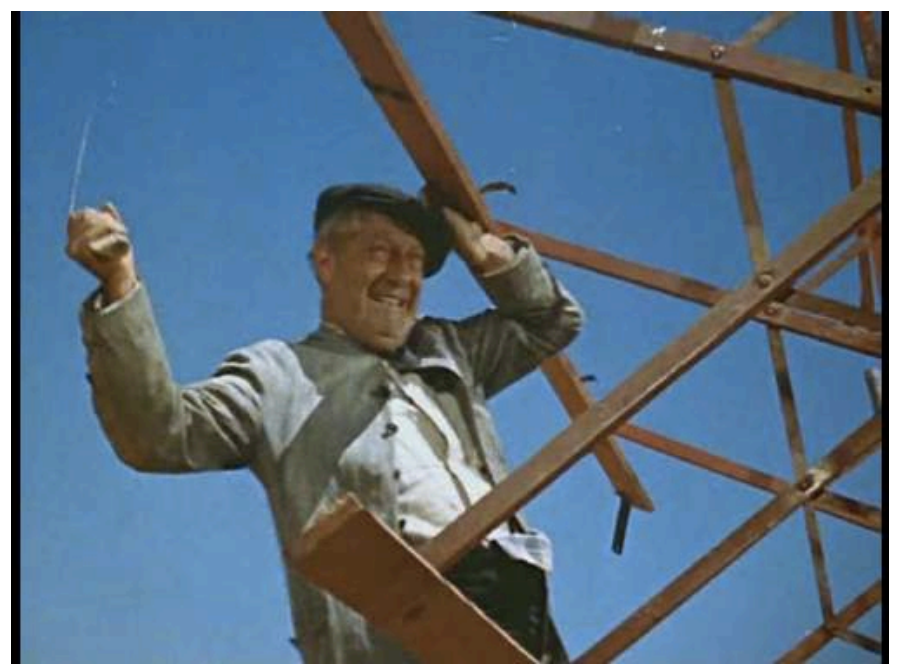

Figura 39c 
En este punto del análisis fílmico, cabe citar la existencia del diario de rodaje firmado por Luciano G. Egido El cine en la cámara. Diario de rodaje de “La venganza” publicado en el número 6 y 8 de Cinema Universitario ${ }^{585}$. Donde también se publicó un fragmento del guion de la secuencia VIII -este mismo episodio, del guion original de Bardem, además de la crítica de Luciano G. Egido en el número 9 de abril de 1959. Una documentación que da cuenta del severo recorte que sufrió el metraje. Las cerca de tres horas de la original Los Segadores quedaron reducidas a ciento veintidós minutos de la versión comercial ${ }^{586}$ acordada, por motivos de censura, en llamarse La venganza, como más adelante se comenta. Dicho recorte afectó a la secuencia que nos ocupa y que en la versión final consta de dos escenas. En la primera se ve a la cuadrilla esperando a la entrada de Herrumblar ${ }^{587}$ las noticias de Luis, el Torcido, mientras son increpados por un lugareño que repite una burla ${ }^{588}$. La segunda, comprende el enfrentamiento de Santiago, el Viejo con la máquina. Mientras que el guion literario dedicaba siete escenas a la secuencia, contribuyendo todas ellas a la descripción psicológica de Santiago: la infructuosa búsqueda de Tinorio (escena 75 y 76), la siguiente negativa de Maxi y Juan (escena 77), el adelantamiento de los segadores gallegos a los trigales de San Carlos del Valle (escena 78), el cambio de dirección antes de llegar a Masegoso (escena 79), la imposibilidad de trabajar en Herrumblar (escena 80) y, finalmente, el descubrimiento de las tres máquinas cosechadoras en los campos de Miguel Esteban (escena 81). Escenas que de haberse representado habrían sustentado la evolución psicológica del personaje del obcecamiento, al enfado y, finalmente, al delirio desencadenando el enfrenamiento con la máquina.

\footnotetext{
${ }^{585}$ Diciembre de 1957.

${ }^{586}$ Un recorte por exigencias de distribución. La versión consultada es de 103 minutos.

${ }^{587}$ Cabe tener en cuenta que el nombre de los diferentes lugares visitados por la cuadrilla protagonista se conoce por el guion literario mientras que en la versión fílmica han sido omitidos.

${ }^{588}$ La anécdota de la burla también fue modificada en la versión cinematográfica. Mientras en el primer guion los chicos del pueblo y el tonto entonan hasta tres veces los versos: "Segadores, de la sierra, ladrones y marrulleros" en la película solo el tonto los pronuncia. Un hecho importante ya que en la versión literaria este suceso contribuye a crear el contexto hostil en que la cuadrilla de temporeros era recibida en algunos de los pueblos.
} 
La riqueza de detalles en que se concibe esta secuencia en el guion literario se reduce considerablemente en la versión fílmica. Por ejemplo la llegada a los campos de Miguel Esteban es inicialmente una celebración al ver los trigales por segar, seguida de asombro de la cuadrilla al ver las tres máquinas cosechadoras. El guion describe en los siguientes términos la reacción de Santiago, el Viejo:

"Estaba loco y hubiese degollado a cualquiera que hubiese querido ponerle la mano encima. $Y$ cuando vio que ninguno se atrevía a aproximarse a él, se volvió rápidamente y emprendió una carrera por en medio del alto trigo, que nadie podía seguir" [...] "loco de sol y de rabia, corría gritando por medio del alto trigo y su mano empuñaba la hoz" [...] "enloquecidos los ojos, rota la voz, descompuesto el gesto terrible de su rostro, brillando amenazante la hoz en su mano".

En el guion literario la cosechadora es "el monstruo" "sobre [el que] había algo con gorra, gafas negras, impasibles, mudos, ciegos, sordo a lo que

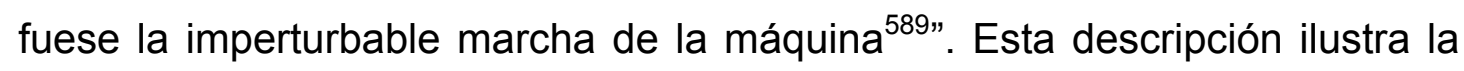
concepción de Bardem sobre la alienación del ser humano con la máquina. En cuanto al carácter monstruoso de las máquinas como comentaba García Escudero, es un recurso ya empleado por Chaplin y Clair ${ }^{590}$. Desde preceptos conservadores Pérez Lozano tacha esta cuestión de:

"Puerilidad social total, pseudobucólica, pensar que, es de una mentalidad moderna, la máquina desplaza al hombre. Esto puede hacer pensar al espectador que la máquina es la enemiga del hombre, cuando el problema social de España es de mecanización. El hecho de que se utilicen máquinas segadoras en España no es un desplazar al hombre, sino un suplir su ausencia ${ }^{591 " .}$.

En conclusión, el tratamiento formal de esta secuencia en la versión final cinematográfica se constituye desde la depuración de todo indicio psicológico del personaje, dificultando la comprensión de su virulenta reacción y

\footnotetext{
589 "Fragmento de la Secuencia VIII del guión de "La venganza" original. "De como la desesperación hizo que Santiago, el Viejo tomara por monstruos enemigos lo que no eran sino máquinas". En Cinema Universitario. Núm. 6. Diciembre 1957, 53.

${ }_{590}^{5}$ Film Ideal. Núm. 20. Junio 1958.

${ }^{591}$ Film Ideal. Núm. 29. Marzo 1959, 24-25.
} 
centrándose, por el contrario, en la dimensión épica del choque desigual entre el hombre y la máquina. De hecho una parte de la crítica quiso ver reminiscencias cervantinas en esta puesta en escena. El propio García Escudero introducía esta referencia en su defensa de la reducción del metraje de La venganza:

"No creo que la obligada reducción del film a las dimensiones llamadas comerciales afecte gravemente a su peso ideológico, aunque sí a sus valores artísticos. 'El Quijote' sería la misma historia, reducido en un tercio, pero evidentemente perdería en su circunstancia y ritmo, y en 'La venganza', creo que la extensión constituye uno de sus más destacados valores, por la andadura serena, verdaderamente clásica, que da a la narración ${ }^{592: " . ~}$

Por lo que Bardem habría abandonado el naturalismo característico de su filmografía anterior más allá de la sencillez del Neorrealismo o del recargamiento del folletín ${ }^{593}$. También los críticos de Film Ideal mencionaban la obra cervantina a la hora de establecer los posibles referentes de la película, limitándose todos ellos a establecer la similitud temática del enfrentamiento con la máquina del mismo modo que Don Quijote hiciese contra los molinos.

En todo caso la dimensión épica del episodio, y por extensión del conjunto de La venganza, contrasta con la premisa inicial de ofrecer "un paisaje documental, ciertamente verdadero 594 " como demuestran los encuadres cenitales o las panorámicas horizontales que recogen con detalle la realidad del campo castellano (fig. 30 y 32). El paisaje es el elemento operador no solo de la línea argumental dramática sino también de la social al condicionar inextricablemente el devenir de los personajes en ambas líneas de acción.

\footnotetext{
${ }^{592}$ Film Ideal. Núm. 20, junio de 1958, 24.

593 Ibídem.

${ }^{594}$ Film Ideal. Núm. 29, marzo de 1959, 24-25.
} 
En conclusión la atención de Bardem al paisaje, a los pueblos y a las gentes, en este preciso orden constatado por García Escudero ${ }^{595}$, fundamenta la línea social de La venganza, ofreciendo una imagen del campo español. Una observación deductiva que en opinión de Luciano G. Egido confiere "el signo realista de sus imágenes, la fidelidad a la problemática contemporánea y el valor de su contenido moral ${ }^{596 " . ~ U n ~}$ argumento sustentado por el compromiso social de Bardem presente en toda su trayectoria desde Esa Pareja Feliz, 1950, las siguientes Muerte de un ciclista o Calle Mayor. Miradas a una realidad concreta de la sociedad española en que La venganza completaría el fresco social que constituye su filmografía.

No obstante en opinión de los críticos de Film ldeal la atención del realizador al entorno rural en La venganza resultó insuficiente. En primer lugar por el largo lapso de tiempo que transcurre hasta la introducción de la línea social, que es cuando aparece también la primera imagen de los campos castellanos $^{597}$. El segundo argumento se basa en el uso de la voz en off como herramienta para narrar el fenómeno universal de la migración temporal y que el grupo de Film Ideal consideraron equivocado por la limitación misma de la voz del narrador. En cambio el padre Landáburu ${ }^{598}$

\footnotetext{
595 "El campo. La impresionante panorámica circular que abre la película nos mete súbitamente en él. Es [...] como una obertura, cuyos motivos se irán después desarrollando, conforme la cuadrilla de segadores avance, arrastrando sus pies cansados, por los largos caminos polvorientos. Después, los pueblos. [...]. Luego la fiesta. [...]. Y las gentes. [...]. La cuadrilla y los encuentros del camino. [...]. Y la gente de los pueblos: esos rostros secos y arrugados, iluminados por el incendio de la era, sobrecogidos por el desastre, desesperados e inmóviles....". En Film Ideal. Núm. 20. Junio de 1958.

596 "Antes que nada y por encima de todo, viene hacia nosotros desde la pantalla un paisaje, un medio geográfico inconfundible, que se despliega ante nosotros desde la pantalla de un paisaje, un medio geográfico inconfundible, que se despliega ante nosotros insistente y exacto, a partir de la panorámica inicial, verdadero prólogo de la historia de los hombres que se nos va a contar. [...]. Después vemos los pueblos, de arquitectura concreta, con las calles empedradas, ahogadas de sol, con las casas enjalbegadas hechas de tiempo y miseria [...] Y sobre todo vemos gentes, hombres y mujeres, con sus vestidos, sus útiles de trabajo, sus formas de vida, sus gestos, sus caras usadas, históricas e indefensas". "Crítica de películas. La venganza (Los segadores)". En Cinema Universitario. Núm. 9. Abril de 1959.

${ }^{597}$ Se trata de una escena de ablenta del trigo recurrente en films de temática rural, como también sucede en ¡Aquí hay petróleo! o Condenados.

${ }^{598}$ El padre Landáburu argumentó así su opinión al respecto del recurso de la voz en off inicial: "Debía haberlo hecho en imágenes, en unos planos rápidos que nos lo contasen de forma cinematográfica. Planos fugaces, en encadenado, de gentes en éxodo, gentes nómadas, con lo cual, al llevar después el problema a una cuadrilla determinada,
} 
proponía un acompañamiento visual a la narración verbal, con imágenes de diferentes gentes desplazándose lo cual situaría a la cuadrilla protagonista como paradigma del fenómeno y el conjunto de la tierra como causa del problema social. Finalmente, el recorte en la duración del metraje ocasionó estos críticos $^{599}$ vieran La venganza como la enumeración de conflictos sin una preparación previa. Un ejemplo se encuentra en la secuencia del enfrentamiento de Santiago, el Viejo con la máquina cosechadora reducida de siete a dos escenas, como demuestra el análisis comparado llevado a cabo. Un hecho que fundamentó la opinión de Flaquer en cuanto que "las coyunturas vienen precipitadas y, por tanto, las conclusiones son también precipitadas $^{600 "}$.

\subsection{La dimensión social del territorio rural}

Juan Antonio Bardem concibió la cuestión rural a partir de las actividades de labranza sin cabida a cuestiones de índole cultural como fuese la construcción identitaria de estas comunidades o sus modos de vida. Una hipótesis que se sustenta en la indefinición espacio-temporal ${ }^{601}$ de la trama de La venganza y que responde a los supuestos universalizadores de la película. No obstante esta imprecisión contrasta con la voluntad testimonial de Bardem, cuyo trasunto fílmico -el escritor interpretado por Fernando Rey, describe con ciertas reminiscencias a los literatos de la Generación del 98:

"Yo me echo a andar y ver porque siento la necesidad de conocer mi tierra y las gentes que en ella viven. $Y$ pienso yo que conociendo a

hubiésemos tenido la sensación de que era una tipificación de lo universal". En Film Ideal. Núm. 29. Marzo de 1959.

599 "5 críticos comentan La venganza". En Film Ideal. Núm. 29. Marzo de 1959. Como resumen de la sobremesa que Pérez Lozano, Félix de Landáburu, Marialay, Lamet y Flaquer tuvieron en el Colegio Mayor Covarrubias "para hacer una crítica colectiva de uno de los films españoles más ambiciosos de nuestra historia", argumentan en el encabezamiento del artículo.

600 lbídem.

${ }^{601}$ Aunque gracias al diario de rodaje de Luciano G. Egido se conocen los lugares en que se rodaron los exteriores de La venganza. Entre el 24 de junio y el 29 de septiembre de 1957 el equipo se desplazó a La Membrilla y la Alhambra (Ciudad Real), Minaya (Albacete), El Toboso (Toledo), Las Pedroñeras y La Mota del Cuervo (Cuenca), Sabiote (Jaén), Loeches y Torredolones (Madrid). 
la una y a los otros me conoceré yo mismo mucho mejor. Porque creo que lo importante es hablar con todos y ver que piensa y que le duele a cada uno, o de que se alegra o cual es su esperanza".

Pero esta premisa inicial no llega a materializarse puesto que los personajes de La venganza son simbólicos y se supeditan a los imperativos de la acción argumental y la función moralizante del propio filme. En esta línea los críticos de Film Ideal hablaban de personajes-tipo sin evolución psicológica, de haberla, como es el caso de personaje de Andrea, esta ligada a la línea dramática. Contrariamente Luciano G. Egido, segundo ayudante de dirección, encontraba el realismo del filme precisamente en el grupo de personajes:

"Hombres reales en su mundo real, que desarrollan un trabajo y llevan a la espalda las necesidades, los deseos, las tradiciones, los errores y los proyectos que su situación les crea y les exige. [...] y ni por un momento dejan de ser consecuentes con su clase social, su género de vida y su tiempo ${ }^{602 "}$.

La representación de la comunidad rural en La venganza se articula a partir de "los estados de solidaridad", en palabras de Egido, este es, el recurso formal de reunión del grupo para hacer frente a los conflictos surgidos a lo largo de su trayecto laboral. Es así como los hombres de la cuadrilla se unen para vengar la agresión a Andrea; se suman a la huelga de los segadores y todos los trabajadores del campo castellano juntos celebran la victoria tras la huelga en el 'plano de la sinfonía'. Sin embargo no existe una indagación sobre las razones y consecuencias de tales conflictos y por tanto no se desarrolla una mirada crítica al respecto. Si no una exaltación de la figura del campesinado dentro del sistema social en la línea del pintor Jean-François Millet. Sin estigmatizar el espacio rural ni victimizar a sus gentes, en La venganza la meseta castellana funciona simbólicamente como el espacio donde caben todos. Precisamente esta región española que mayor atención ha recibido a lo largo de la historia en los momentos de reformulaciones identitarias, como sucedió durante la crisis finisecular que

${ }^{602}$ Cinema Universitario. Núm.9. Abril de 1959, 63. 
fundamentó el pensamiento regeneracionista y de los autores de la Generación del 98 como se ha argumentado. Un perfil encarnado por el arquetipo del escritor como analogía de estos intelectuales. El personaje de Fernando Rey es el único capacitado para razonar y transmitir un mensaje de solidaridad al estamento campesino. En la segunda parte del monólogo el personaje argumenta:

"Que muchas veces los enemigos lo son por estar apartados y sin hablar, y no por otra cosa. Porque nadie puede vivir solo y nadie está solo. Y cada hombre debe contar con su vecino. Y así la mejor palabra es 'amigo' que quiere decir lo contrario de egoísta. Al amigo se le conoce porque olvida, y si ha de perdonar, perdona. De este modo el corazón está como limpio y a punto para latir de nuevo.

Esta tierra nuestra, lo que de ella conozco, es grande y hermosa, a ratos buena, a ratos mala. $Y$ en ella estamos todos juntos, todos somos vecinos. $Y$ todos podemos ser amigos. Por eso nadie puede sembrar cizaña y llamar a unos buenos y a otros malos. Porque de todo hay y mezclado.

Se me antoja que todos formamos como una gran cuadrilla, cada uno con sus cosas por dentro, pero todos juntos, todos a la par, todos segando la misma mies".

Diegéticamente el razonamiento del escritor resulta arbitrario y su presencia injustificada, lo que reduce su función a vehículo para la formulación del mensaje moralizante del filme ${ }^{603}$. Es más, el protagonismo del discurso oral supedita el soporte formal a una función plástica. Un recurso tachado de refuerzo que combatía la ineficacia visual de La venganza. En esta línea discurrió la interpretación de García Escudero ${ }^{604}$ al defender que el fondo social y el fenómeno migratorio, como tema sociológico, habían quedado supeditados al objetivo moralizante, elemento que dotaba de trascendencia social a La venganza.

\footnotetext{
${ }^{603}$ Un personaje recurrente en la filmografía de Bardem, en palabras de García Escudero "es el testigo sermoneador y moralizante, pedante predicador laico que en todas sus películas mete Bardem". Film Ideal. Núm. 20. Junio de 1958, 24-25.

${ }^{604}$ Ibídem.
} 
En definitiva, la película de Bardem "[cargaba el acento] sobre lo moral, siendo lo social una dimensión esencial del drama, pero nada más que una parte del todo que constituye ese complejo moral, ese sujeto de responsabilidades, esa determinada forma de ser hombre ${ }^{605}$ ". La venganza partía de la forma del drama rural para lanzar una premisa moral acorde a la línea militante de Bardem en el contexto de cuestionamiento de las fórmulas predominantes de expresión artísticas y la transformación de los discursos políticos del régimen franquista.

A pesar de todos los debates que despertó la película de Bardem los textos promocionales coincidía de nuevo en determinar que "en ese paisaje está, en algún momento, España ${ }^{606 " . ~ L o ~ q u e ~ p o r ~ o t r a ~ p a r t e ~ c o r r o b o r a r i ́ a ~ l a ~}$ intención de situar La venganza en la tradición de los pensadores regeneracionistas y los escritores de la Generación del 98. Ilustrativo al respecto es la descripción del propio Bardem del primer encuadre de acción en los trigales castellanos, "se ve España y después pequeña panorámica hasta que entren en campo los actores segando ${ }^{607}$ ".

La prensa cinematográfica también coincidió en identificar La guerra de Dios en la tradición representativa de la esencia nacional. "Pertenece al estilo clásico del cine español ... por sus tipos, paisajes y reflejo de las costumbres $^{608 " . ~ S i n ~ e m b a r g o ~ r e s u l t a ~ e x c e p c i o n a l ~ e l ~ a r t i ́ c u l o ~ d e ~ P r i m e r ~ P l a n o ~}$ que abordaba la descripción del conflicto social de la película:

"El argumento nos plantea un problema social tremendo. No sólo por lo que supone el duro y peligroso trabajo de los mineros, sino por los antagonismos feroces entre patronos y obreros. Hay una lucha sorda que puede explotar en cualquier momento. Los de abajo se sienten incomprendidos, y los de arriba no quieren saber nada de los problemas de sus mineros. Accidentes, falta de medios económicos,

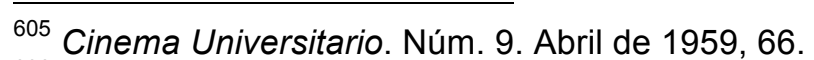

${ }^{606}$ Lamet. Film Ideal. Núm. 29. Marzo de 1959

${ }^{607}$ A propósito de la secuencia en que Tinorio se hiere con la hoz. El cine en la cámara. Diario de rodaje de "La venganza", 9 de julio. En Cinema Universitario. Núm. 8. Diciembre de 1958.

${ }^{608}$ Primer Plano. Núm. 670. 16 de agosto de 1953. Año XIII.
} 
dolor; todo se transforma en odio, un odio apasionado que alcanza hasta a los niños ${ }^{609 "}$.

No obstante la tipificación del odio entre los estamentos rurales deriva la inicial crítica a esta realidad social hacia el dramatismo cinematográfico. Como también sucede en otro texto de Primer Plano que anuncia La guerra de Dios como "Una película distinta dentro del cine español. Todo el odio de la lucha de clases planteado y resuelto a la manera española ${ }^{610 "}$.

En conclusión, atendiendo a la presencia del régimen franquista en todas las facetas de la vida española de los años cincuenta, en el ámbito de la prensa especializada convergieron los anhelos políticos por ofrecer una imagen reconocible de la llamada 'esencia nacional' a través de las diferentes formulaciones del paisaje español. Cabe apuntar la intervención de la Junta de Clasificación y Censura en La venganza. Juan Antonio Bardem confesó al respecto: "me obligaron a situar la historia en 1930, con lo que se echaba al liberalismo la culpa de cuanto ocurría ${ }^{611 " . ~ D e ~ l a ~ m i s m a ~ m a n e r a, ~ e l ~ a r g u m e n t o ~}$ de Amanecer en Puerta Oscura se situó en la Andalucía del siglo XX "cuando la inquietud política y el malestar social condicionaban la vida del país y justificaban la lucha y la revuelta ${ }^{612 ", ~ a r g u m e n t a ~ S a ́ n c h e z ~ V i d a l ~ q u i e n ~ t a m b i e ́ n ~}$ revela la preocupación de la censura ante posibles identificaciones de la compañía minera inglesa de la ficción con los americanos, recordando que eran el nuevo aliado político del régimen. No existe expediente de la Junta de Clasificación y Censura de La guerra de Dios por lo que no puede justificarse el motivo de la localización del argumento en la década de 1930. En definitiva, la constatación visual de la ruralidad española en La venganza, al igual que en La guerra de Dios o Amanecer en Puerta Oscura respondía a los preceptos de un testimonio amable que no contradecía los postulados del régimen franquista, promoviendo la exportación de la nueva imagen de España en un momento crucial para la supervivencia del régimen.

\footnotetext{
${ }^{609}$ Primer Plano. Núm. 665. 12 de julio de 1953. Año XIII.

610 Primer Plano. Núm. 651. 5 de abril de 1953. Año XIII.

611 'La venganza' reconciliación frustrada. Diego Galán, El País, 14 octubre 1983. Es preciso señalar que al menos en la versión comercial del filme no existe referencia al año en que se sitúa el argumento.

${ }^{612}$ Sánchez en Pérez (Coord.), 1997: 413-415.
} 


\section{Conclusions}

Finishing the path along the cinematographic uses of the Spanish rural space with La venganza has a special meaning. Juan Antonio Bardem's film peeks into the Spanish countryside before technification, tourism, capitalism and migration, i.e. before the modernization of the country. In a way, modernization entails the last step in a threat that arose in the first stages of the industrialization of the country, through images tinged with romantic nostalgia, as in Jean Laurent, Charles Clifford or José Ortiz Echagüe. These photographers believed they had found the last remains of authenticity in the remotest corners of Spain. Their photo series, as well as the written works of Miguel de Unamuno, Azorín, Antonio and Manuel Machado or the regenerationist reflections of Joaquín Costa would literally submerge into the rural Castile in an attempt to reconcile with the customs of yesteryear, long gone as the turn-of-the-century crisis brought to the fore.

Spain's incorporation to the path of modernism was materialized in 1959 with the beginning of the so-called economic miracle that was stimulated from the urban framework and the touristic coasts. The Spanish countryside practically disappeared from the horizons of filmmakers. In February 1959, Bardem premiered La venganza in Spain after having shown it in Cannes and Hollywood. A model of the first generation of filmmakers who understood their profession from the academic perspective, he united his compromise for a testimonial cinema with his political affiliation in this film. To do so, he looked at the Castilian plateau as the territory from which he could spread the message of national reconciliation of the Partido Comunista de España. It was precisely the Castile walked by the noble Don Quixote the one explored by the writers of the Generation of '98 in great detail. Furthermore, the regenerationists focused on their crusade to reinstate the meaning of the idea of Spain and the Francoist intellectuals were revisited. In this manner, Bardem had opened a social way in the uses of space of the rural cinema that connected to the discourses of the writers of the Generation of ' 98. 
However, Bardem's proposal was not continued, at least in the following years. It was not until the 70 s and the 80 s that the Spanish cinema turned towards the rural environment again, which had already become a mirror of an exhausted Spain that had been mistreated by the dictatorship. It was then when the critical conscience of its filmmakers would manifestly impregnate the condescending, nostalgic or censor looks that these films offered of the countryside.

For all these reasons, La venganza becomes the last step in the evolution of the cinematographic gaze on the Spanish countryside before modernization. This transformation took place in a strong bond with the transformation of the space in the country as a consequence of economic development policies, architectural reconstruction and liberalization movements in the population that were directed to overcome the unworkability of the autarchy. These dynamics imply a continuous movement identified by Ann Davis in her analysis of the entity of Spain as 'process of becoming' in which the countryside has traditionally worked as a common framework of aesthetic, social and cultural references in moments of identity reformulation.

The Spanish rural cinema produced between 1950 and 1959 precisely coincided with a crisis of values as a result of the Spanish Civil War and the subsequent dictatorial regime. This cinema production, a minority within the history of the industry, not only did work as a reflection of the tensions, desires and traumas of a country in the process of reconstruction, but it also intervened as a perpetuating agent of a collective imaginary as it "ofrece una serie de narrativas, imágenes y arquetipos que hacen reconocible, en un tiempo y espacio perdurable, al ojo del público masivo ${ }^{613 " . ~ T h e ~ C a s t i l i a n ~}$ landscapes like the mountains of Almeria in Sierra maldita or the Valencian lagoon in Cañas y barro initially illustrate the regionalisms of the country. Nevertheless, the nature in the landscape as a cultural identity is a consequence of both the organizing gaze that agreed on defining the forms of

\footnotetext{
${ }^{613}$ García Carrión, 2013a:196. "Offers a series of narratives, images and archetypes which are recognizable in a lasting time and space for the eye of the grand audience". Translation by the author.
} 
these spaces and also de ulterior interpretations of the cinematographic press that was close to pro-government discourses. As happened in the pictorial realm, the intellectual elites within the Francoist regime tried to find formulae for an art of their own that would serve to palliate the artistic poverty of those years and, at the same time, would control any possible social agitations through the exaltation of ancient values, which were to be found in rural milieu. This determination was brought to their maximum in the editorial lines of the magazines Primer Plano, Radiocinema or Film Ideal, which interpreted the particularity of regionalism as an archetype of the national essence. An example of this is the text used by Radiocinema to advertise Sierra maldita in the issue 236 in 1955 :

"Cine típicamente español, fuerte y entero, rodado en exteriores naturales de belleza incomparable, con valores para intentar la conquista del mundo [...] una línea de cine español, sin concesiones al folklore de exportación, eminentemente racial, marca un camino y señala la meta que puede expandir nuestro celuloide por doquier, para acreditar así los auténticos valores nacionales ${ }^{614 "}$.

This fact illustrates the complexity of the landscape as a boosted cultural entity when manifesting the images in the cinematographic format, whose value, as defined by García Carrión, allows for a socio-historical approach, in Marco Ferro's terms, to the Spanish postmodernist period.

It is necessary to bear in mind two fundamental ideas. First, the military and strategic essence of the Francoist regime superimposed the ideological foundations commonly found in Italian and German fascisms, which explains the changes in the course of politics and the successive reforms of governments directed to palliating the most immediate needs. These circumstances, from a historiographic perspective, reveal endless contradictions when comparing the theoretical principles to the practical actions. In this sense, the Francoist consideration of the Spanish countryside

614 "Typical Spanish cinema: strong and full, shot in natural exteriors of incomparable beauty, with values to attempt the conquest of the world [...] a line of Spanish cinema, without concessions to exported folklore, eminently racial, it paves the way and points to the goal that our celluloid may be expanded everywhere, thus acknowledging authentic national values". Translation by the author. 
is one of the most symptomatic paradoxes. Praised by the dictator, Ramón Serrano Suñer, and even by José Antonio Primo de Rivera in the early stages of the construction of his autarchic model, the Spanish countryside would not only be the economic driving force, but also the source for the values that the Francoist regime was trying to impose. It is worth highlighting that one of the pillars of the project for reconstruction, the Plan de Obras, Colonización, Transformación y Electrificación (Plan for Construction, Colonization, Transformation and Electrification), in the province of Badajoz, focused, precisely, in the reactivation of the farm work in the Extremaduran region. However, the already old-fashioned and poor Spanish countryside, deteriorated by the Civil War, demonstrated that the rural milieu would not generate enough employments and, therefore, the migratory flux to the province capitals and abroad did not come to a stop in the 40s, and it even increased in the 50s and led to the creation of the Instituto Nacional de Emigración (National Institute for Migration) in 1956. In conclusion, the initial Francoist praise to the countryside became utopian in practical terms.

Secondly, the aforementioned nature, which was constitutive of the Francoist regime, did not contemplate a programmed action in the artisticcultural sphere as far as dirigisme is concerned, and it is more suitable to explore its effect in terms of intervention. In the area of the national cinematographic industry, the Francoist regime weaved a legislative and commercial structure that significantly defined its development. The state protectionism and the judicial and moral censorship demonstrated the dependence of the industry to a series of models that did not work out of habit. Establishing parallelisms with the rural cinema at that time, this fact is exemplified by the folklore-populist corpus of films like María Morena, La montaña sin ley or Estrella de Sierra Morena, which reproduce the formulae in popular shows in which religious elements stand out as the unifying thread in narrations that were "construidas para cantar [...] las alabanzas de los imperecederos y recios valores y tradiciones regionales de los pueblos de la 
patria ${ }^{615 " . ~ I t ~ i s ~ a ~ t y p e ~ o f ~ c i n e m a ~ t h a t ~ r e p e a t s ~ f o r m u l a e ~ f r o m ~ p a s t ~ d e c a d e s ~ b u t ~}$ which now succumbs to the glorification of rural spaces looking from the nostalgia of a present which is orphan of referents of its own. In fact, the displacement of the narrative time in La picara molinera, or the indetermination of Carne de horca refer to a 'conceived' imaginary, using Henri Lefebvre's terms, that has to do with a myth focused on the archetypes of the flamenco singer and the bandit. It may be concluded that the use of rural spaces in this set of films responds to the primary need of establishing a framework -setting-where the respective narrations can be developed.

The assimilation of Martin Lefebvre's work, which tries to identify the three levels in which the experience of space is manifested -setting, landscape and territory, together with Henri Lefebvre's theories of the perceived, conceived or lived spaces, and Ann Davies, who defines four levels -space, place, landscape and territory, have been essential to focus this dissertation in the levels of landscape and territory due to the complexity that emerges from their constitution as cultural entities. This transcends the peculiarities of the format in which their images are expressed to a socio-political dimension of creation of collective imaginaries. In the films Condenados, Sierra maldita, and Cañas $y$ barro the countryside is seen as a landscape that has been conceived both aesthetically and conceptually from the bond between the land and women; a union that has been theorized by Carmen Arocena and Nira Yuval-Davies, which, at the same time, refers to mythical schemata assimilating women to the land and the farm work as generating act through the Vedic beliefs. Mur Orti assimilated this mythical-ritual synthesis defined by Mircea Eliade when looking at the Castilian plateau and developing the tragedy in Condenados in it. This fact corroborates the effect of the rural landscape on the dramatic register of the film, following Jesús González Requena's definition of rural drama genre. This filmmaker's practice is rather peculiar when considering the subjectivity of each subject-creator when ordering space. For instance, Mur Oti emphasizes the formal depuration of the metaphysical question

\footnotetext{
${ }^{615}$ Poyato (Coord.), 2007: 75-98. "Developed to be sung [...] the praises of the everlasting and sturdy regional values and traditions of the peoples of the homeland". Translation by the author.
} 
exclusively centered on the primary condition of human relations while excluding any localisms.

The gaze to the landscapes in Sierra maldita and Cañas y barro in fact include the paisanaje mentioned by Unamuno which amplifies the gaze to the social dimension of the spaces. However, the three films reproduce the codes of the rural drama genre, which makes it difficult to identify in veristic terms the problematics that sustain their plots. It is paradigmatic that Sierra maldita is based on a legend, which contributes to the perception on the Almerian range as focused on small mountain villages which are representative of the most atavistic rural communities of the past. On the other hand, Cañas $y$ barro, although set in the Spain in between centuries, follows the imperative of the naturalistic description of Blasco lbañez's works, and it shows a rural community that lives off the land, although such exploitation does not constitute a problem for its main characters unlike in Agua sangrienta or in Las aguas bajan negras. Nevertheless, the geographical peculiarities of the island of the Albufera identify this community as a primary group governed by strong bonds of kinship and of neighborhood whose domestic economy makes the land their primary source of supply in the terms theorized by Boguslaw Galeski. These are features that narratively "embody the patriarchal values of traditionalist Spanish society ${ }^{616 " ~ p l a c i n g ~ w o m e n ~ i n ~ t h e ~ e p i c e n t e r ~ o f ~}$ possible threats. All in all, it is verified that the protagonists of these three rural dramas are mistreated by the patriarchal system which looks away by impeding their development into active subjects and reducing them to a reproductive role, as analyzed by Carmen Arocena and Nira Yuval-Davies.

Going back to the idea of the ontological connection between women and land, both entities are part of a landscape that is looked at by a masculine subject who desires and fears them at the same time whereby depends the evolution of the feminine archetypes. Finally, the codes of the rural drama charge at women's integrity, for which there is no diegetic justification. In conclusion, an analogy may be established for the feminine body, which

${ }^{616}$ D'Lugo in Harper; Rayner, 2010: 94. 
works as a metaphor of the Spanish countryside, historically mistreated for those who also worship it. This issue has no repercussion in press texts advertising the films at the time. The magazines Primer Plano, Radiocinema or Film Ideal, which used to have a larger reach in those years, agreed on promoting Condenados "como una tragedia griega de celos localizada en áspera Castilla, con lo que trama, tipos y episodios se nos ofrecen con una gran rudeza que da a la obra un sello singularísimo, inconfundible ${ }^{617 " . ~ S i e r r a ~}$ Maldita was seen as a "drama intenso que discurre entre la cuadrada arquitectura del pueblo serrano para perderse entre los riscos de la Niña Negra, en donde se matizan o se acentúan las pasiones entre los hombres 618 ". These interpretations corroborate the assimilation of the landscape in the dramatic register of the rural drama genre.

The search for the dramatic sense of the Spanish rural landscape made the production crews to move to real locations, leaving the comfort of shooting sets. However, these trips did not aim to capture the immediacy of the native land in terms of verism, but the authenticity in the expression of the sentimental passions as in Condenados. In their project Cinco Historias de España, Cesare Zavattini, Luis G. Berlanga and Muñoz Suay also moved from one place to the other throughout the Spanish geography in a search for the authenticity of the national territory just like the regenerationists and the authors of the Generation of '98 did in the past. This feat provides their project with a dimension of commitment in the framework of the national cinematographic inflection as brought to the fore in the Conversaciones de Salamanca (Conversations of Salamanca). If the project had been executed, it would have been a benchmark in the gaze of the Spanish countryside as a lived territory. Muñoz Suay confessed that he liked "la idea de escribir unas historias que transcurriesen en España, pero que no fuesen inventadas de

\footnotetext{
${ }^{617}$ Primer Plano. Núm. 673. Año XIII. 6 de septiembre de 1953. "As a Greek tragedy about jealousy which was set in the rough Castile. Consequently, the plot, types and episodes are offered with a great roughness which provides the film with a distinctive singular façade". Translation by the author.

${ }^{618}$ Radiocinema. Núm. 224. November 1954. "An intense drama which runs along the squared architecture of the mountain village to get lost among the crags of Niña Negra, where the passions among men are explored and accentuated". Translation by the author.
} 
antemano. Queríamos escribirlas después de haberlas visto y oído ${ }^{619 ", ~ a n d ~}$ the protagonists would be the peoples that they would have encountered on the way. The stories El pastor, Emigrantes and Las Hurdes compile the vicissitudes of the social condition of a shepherd, a peasant family and the inhabitants of a village by the Hurdan region respectively. In short, this would have been a look at the countryside from the subjectivity of their experiences, using Martin Lefebvre's terms.

As defended by Ann Davies, the multiplicity of subjects that tackle the use of space originates a diversity of perspectives, even though they are all placed in one single level. La guerra de Dios and Amanecer en Puerta Oscura in a partial manner, and La venganza throughout the full length tackled the representation of the Spanish countryside from the perspective of the work practices, as an element to identify the rural territory. Although the working conditions culminated in social conflicts in the former two cases, their resolution is diverted towards the consecution of religious topics. Moreover, in La venganza, the international prestige of Juan Antonio Bardem, together with the extent of the coproduction of the project and the presence of Carmen Sevila, Jorge Mistral and Raf Vallone as representatives of the national Star System did not allow for the development of a lived gaze at the Castilian plateau.

With the exception of Cinco Historias de España, no approaches can be found that would truly go into detail on the intra-history of the territories as promulgated by Miguel de Unamuno in the multiplicity of forms of the landscape and the territory adopting the uses of space of the Spanish rural cinema in the 50s. The problems with droughts, the social hierarchy or the lack of protection of women are resolved by using the generic formulae of dramas, musicals or comedies. In the cases in which plots contained elements that would be potentially critical of the Francoist political system, the censor machine would convene its movement to a bygone time. The temporal

\footnotetext{
${ }^{619}$ Zavattini, Berlanga, Muñoz Suay, 1991: Introduction. "The idea of writing stories that occurred in Spain, but that were not invented beforehand. We wanted to write them after having seen them and heard them". Translation by the author.
} 
disruption was also present in films which, from myth lens, would feed the rural imaginary based on the exotic Andalusia and contributed to the exaltation of ancient values. In short, from a historiographic perspective, the lack of a critical dimension with the reality of the Spanish countryside was lined up with other artistic manifestations that, as a whole, were innocuous as protests against the Francoist administration.

The novelty of this dissertation lies in the recreation of the framework of synergies for the reformulation of the referents of the national values, taking into account the dialog between the filmic discursive formulae and the political strategies of the Francoist regime, as well as the status of the development of the cinematographic industry with the uses of space and their meanings. This is a context of transformation in which new crevices were opened, like the focus of the Instituto de Innovaciones y Experiencias Cinematográficas (Institute of Innovations and Cinematographic Experiences), their first promotional sessions of filmmakers that were committed to the cinema, the meeting of the Conversaciones de Salamanca (Conversations of Salamanca), or the specialized publication in cinematographic review: Objetivo. The existing system began to be questioned from these spaces, although that would not constitute a group of dissidents as such. Besides Juan Antonio Bardem, Luis G. Berlanga, who took part in these debates, also became immersed in the rural cinema with Bienvenido Mr. Marshall, in which he develops a use of space reminiscent of the symbolic power of the Castilian rural spaces in the definition of national identity, thus exemplifying the materialization of new formulae for the Spanish cinema.

Surcos, Antonio Nieves Conde's film is illustrative of this in two aspects. First, the Falangist profile of the filmmaker was aligned, already in 1951, with those idealists that were disappointed by the ineffectiveness of the Francoist regime. Second, it is illustrative because of the boldness in the election of a topic and its formal treatment: the rural exodus, one of the biggest problems of the Spain of mid- $20^{\text {th }}$ century. In the context of this thesis, the use of the rural space in Surcos is outside the framing, although it is centered on the protagonist family, which is identified as a group of emigrated peasants, 
foreigners in the outskirts of Madrid. This will corrupt their model as a traditional family. In conclusion, Surcos is the only direct reference to the problem of the rural exodus.

The constitutive nature of the landscape and territory manifestations implies a subjective perspective that will express specific desires, traumas and backgrounds. The images of rural cinema analyzed here verify the multiplicity of forms generated by the experience of the Spanish countryside, even though there is no ideal form of rural cinema; in other words, it is not clearly defined as a cinematographic genre. It encompasses anything, from the conceived formulae in the margins of exoticism emulating the codes of Westerns and the most popular musical shows to the fables that go deeper into the unknown using fear and surprise. These ways are reminiscent of a cinema that absorbed the Andalusian regionalism as synecdoche of the national identity; rural dramas whose constitutive codes would impose the depuration of their plots, setting them outside of the historical time. This formal treatment allowed the rural landscape to be part of the dramatic register, providing it with a cultural value. It also provided many other formulae like: the religious cinema that used the atavism of the rural community where the religious archetype was found in order to extoll it as mediational figure which would carry the new values of the national-Catholicism; or the melodrama that would find in the rural sceneries the element to emphasize its dramatic register.

All in all, this cultural analysis of the images of the Spanish rural cinema aims to open a framework to address the uses of rural spaces and their meanings in a full sense. In other words, from the conceptualization of the process of artistic translation of the experience in the natural environment, to the political readings arising from its presence in the collective imaginaries of the definition of national identities. There is no ideal way to represent the Spanish countryside, but the cultural value of this space arises from the multiplicity of perspectives that have historically looked at it. 


\section{ANEXO FICHAS FILMOGRAFÍA}

\section{LA GUERRA DE DIOS de Rafael Gil, 1953}

Productora: $\quad$ Aspa Producciones Cinematográficas, S. A.

Distribuidora: CIFESA

Dirección: Rafael Gil

Argumento y guión: Vicente Escrivá

Guión técnico: Vicente Escrivá y Ramón D. Faraldo

Fotografía: Alfredo Fraile

Música: Joaquín Rodríguez

Montaje: José Antonio Rojo

Sonido: Amadeo Torno

Sistema sonoro: Laffón Selgas

Dirección artística: E. Torre de la Fuente

Decorados: Enrique Alarcón

Ayte. de dirección: José Luis Rodríguez, Pedro L. Ramírez

Segundo operador: César Fraile

Claude Laydu (Andrés Mendoza),

Francisco Rabal (Martín),

Marco Davo (Don César), Fernando Sancho (Barrena),

Gerard Tichy (Negro),

Intérpretes:

Carmen Rodríguez (Madre de Andrés),

Julia Caba Alba (Mujer del alcalde),

Félix Defauce (Secretario),

José Sepúlveda (Doctor),

María Eugenia Escrivá (Margarita),

Jaime Blanch (Daniel), Irene Gutiérrez Caba (Irene)

Metraje: $\quad 2.797$ metros

Duración: 102 minutos

Estreno: $\quad 30$ de septiembre de 1953, cine Rialto, Madrid

Expediente de Archivo General de la Administración. Caja 36/0456, rodaje: $\quad$ expediente 11.843 


\section{CONDENADOS de Manuel Mur Oti, $1953^{620}$}

Productora: Cervantes Filmes

Distribuidora: CIFESA

Dirección: Manuel Mur Oti

Argumento

Basado en la obra teatral homónima de José Suárez

Carreño (Premio Lope de Vega, 1951)

Guión: Manuel Mur Oti

Fotografía: Manuel Berenguer

Música: Ludwig van Beethoven

Dirección musical Jesús Arrámbarri

Coral: Cantores de Madrid

Solista de piano: Enrique Aroca

Montaje: Antonio Gimeno

Sonido: Paulino García Velázquez

Decorados: Manuel Garnelo

Jefe de producción: Antonio Vich

Ayte. de dirección: Vicente Lluch

Srio. de rodaje: Mateo Cano

Ayte. de sonido: Manuel Mora

Segundo operador: César Benítez

Ayte. de cámara: Eduardo Noé y Abelardo Rodríguez

Ayte. de montaje: Mercedes Gimeno

Regidor: Antonio Montoya

Foto fija: Claudio Gómez Grau

Construcción de

decorados: Augusta Lega

Atrezo y mobiliario: Toledano

Figurines y

ambientación: Carlos Santiesteban

Vestuario: Hermanos Peris y Monic

Maquillaje: Carlos Nin

${ }^{620}$ Zubiaur, 2013: 532. 
Intérpretes: $\quad$ Aurora Bautista (Aurelia), Carlos Lemos (José), José Suárez (Juan), Félix Fernández (Tabernero), Aníbal Vela (Salvador), Eugenio Domingo (Pastor), Antonio Díaz del Castillo (Ignacio),

Pedro Ignacio Paul (Manuel)

Estudios de rodaje: Ballesteros, Madrid

Exteriores

Laboratorio:

Sistema sonoro:

Permiso de rodaje: 14 de abril de 1953

Metraje:

Duración:

Calificación adtva.: Primera A

Calificación moral:

Estreno:

Festivales:

Premios:

Expediente de rodaje:

Expediente de censura:

Ballesteros, Madrid

R.C.A.

2.900 metros

90 minutos

Calatravas (Madrid) 1955
Argamasilla de Alba, Ciudad Real

Autorizada mayores de 16 años y posteriormente para todos los públicos

16 de noviembre de 1953, cines Gran via y

Sección Oficial del Festival de Sao Paulo, 1954, Festival de Locarno, 1955

Accésit del Sindicato Nacional del Espectáculo a la película, 1954; Premio del Círculo de Escritores Cinematográficos a Manuel Berenguer por la mejor fotografía, 1954; Bandera de Honor para Aurora Bautista y Manuel Mur Oti en el Festival de Locarno,

Archivo General de la Administración. Caja 36/04736, expediente 13.807

Archivo General de la Administración. Caja 36/03464, expediente 12.069 
CAÑAS Y BARRO de Juan de Orduña, 1954

Productora: $\quad$ Producciones Orduña Films, Pico Films (Roma)

Distribuidora: CIFESA

Título italiano: La palude el peccato

Dirección: Juan de Orduña

Argumento: Basado en la novela homónima de

Vicente Blasco Ibáñez, 1902

Guión: Manuel Tamayo

Fotografía: José Fernández Aguayo

Música: R. Lamote de Grignon

Montaje: Antonio Cánovas

Sonido: $\quad$ Enrique de la Riva

Dirección artística: Sigfrido Burmann

Decorados: Enrique Bronchalo

Jefe de producción: Telesforo de la Plaza

Segundo operador: Ricardo Navarrete

Ana Amendola (Nela), Virgilio Teixeira (Tonet),

Aurora Redondo (Samaruca), José Nieto (Tío Toni),

Félix Fernández (Tio Paloma), Saro Urzi (Cañamel),

Intérpretes: Delia Scala (Marieta), Erno Crisa (Jaime),

Tarsila Criado (Tia Vicenta),

Luis Orduña (Padre Miguel),

Juan Capri (Sangonera)

Estudios de rodaje: Orphea Films, Barcelona

Laboratorio: Cinefoto Aragón y Pujol S.L., Barcelona

Permiso de rodaje: 14 de marzo de 1953

Duración: 106 minutos

Calificación moral: Rosa fuerte, $3 R$

Estreno:

3-10-1954, cines Carlos III, Roxy B, Rialto, Madrid

Expediente de Archivo General de la Administración.

rodaje: $\quad$ Caja 36/04735, expediente 12.887 
SIERRA MALDITA de Antonio del Amo, 1954

Productora: Producciones Almasirio de Cinematografía, S.A.

Distribuidora: Exclusivas Diana, Paramount Film

Dirección: Antonio del Amo

Ayte. de

dirección

José Luis Merino Boves

Guión:

Alfonso Paso, José Luis Dibildos

Fotografía: Sebastián Perera Soriano

Música:

Jesús Romo

Montaje:

Pepita Orduña

Sonido:

Jaime Torrens

Coros:

Escolanía de tiples del maestro Dúo Vitale

Segundo

operador:

Intérpretes:

Ángel Ampuero

Rubén Rojo (Juan), Lina Rosales (Cruz),

José García Guardiola (Lucas), José Sepúlveda (José),

José Latorre Almerich (Padre Agustín),

Agustín Rivero Torres (Víctor),

Metraje: $\quad 2.893$ metros

Duración: 106 minutos

Calificación

adtva.:

Primera A

Estreno:

1 de diciembre de 1954 cine Coliseum (Barcelona),

30 de enero de 1955, cines Callao (Madrid)

Festivales: I Festival Internacional de San Sebastián

Premios:

Mejor película española

I Festival Internacional de San Sebastián 


\title{
LA VENGANZA de Juan Antonio Bardem, 1957
}

\author{
Productora: \\ Guión P.C. Y Vides S.P.A. Para Suevia Films \\ Distribuidora: \\ Metro Goldwyn Mayer \\ Productor: \\ Manuel J. Goyanes \\ Dirección: \\ Juan Antonio Bardem \\ Argumento y guión: Juan Antonio Bardem \\ Fotografía: \\ Mario Pacheco \\ Sistema de filmación: Eastmancolor \\ Música: \\ Isidro B. Maiztegui y Maestro Quiroga \\ Coros: \\ Cantores de Madrid dirigidos por José Perera, \\ Coplista Roque Montoya 'Jarrito' \\ Montaje: Margarita Ochoa \\ Sonido: \\ Fernando Bernáldez \\ Decorados: \\ Manuel Alarcón \\ Jefe de producción: Samuel Menkes \\ Ayte. de producción: Miguel Pérez Marián \\ Ayte. de dirección: Ricardo Blasco \\ Secretario dirección: Carlos de los Llanos \\ Segundos \\ ayudantes: \\ Juan Estelrich y Luciano G. Egido \\ Operador: \\ Julio Ortas \\ Foto-fija: \\ Felipe López \\ Decorados: \\ Francisco R. Asensio \\ Atrezo y mobiliario: \\ Menjíbar, Luna y Mateos \\ Vestuario: \\ Humberto Cornejo \\ Maquillaje: \\ Carmen Martín \\ Carmen Sevilla (Andrea), \\ Raf Vallone (Luis, El Torcido), \\ Jorge Mistral (Juan), \\ José Prada (Santiago, el Viejo), \\ Intérpretes: \\ Manuel Alexandre (Tinorio), \\ Manuel Peiro (el muchacho), \\ Conchita Baustista (cantante), \\ José Marco Davo (capataz), \\ Rafael Bardem (médico), \\ María Zanoli (la madre),
}


Fernando Rey (el escritor)

Estudios de rodaje: Chamartín, Madrid

Exteriores:

Cuenca, Toledo, Ciudad Real, Albacete, Jaén y Madrid

Laboratorio:

Fotofilm S.A.E. (Barcelona)

Sistema sonoro: R.C.A.

Permiso de rodaje: 22 de noviembre de 1957

1a copia estándar: $\quad 2$ de septiembre de 1959

Metraje: 12 rollos

Costo total:

7.458.403 pesetas según productora/

6.975.000 pesetas según Junta Clasificación y Censura

Calificación adtva:: Primera A

Festivales:

Festival Internacional de Cannes, 1958

Premios:

Federación Internacional de la Prensa Cinematográfica, Festival de Cannes 1958

Expediente de

rodaje:

Archivo General de la Administración. Caja 36/ 04776 


\section{AMANECER EN PUERTA OSCURA de José María Forqué, 1957}

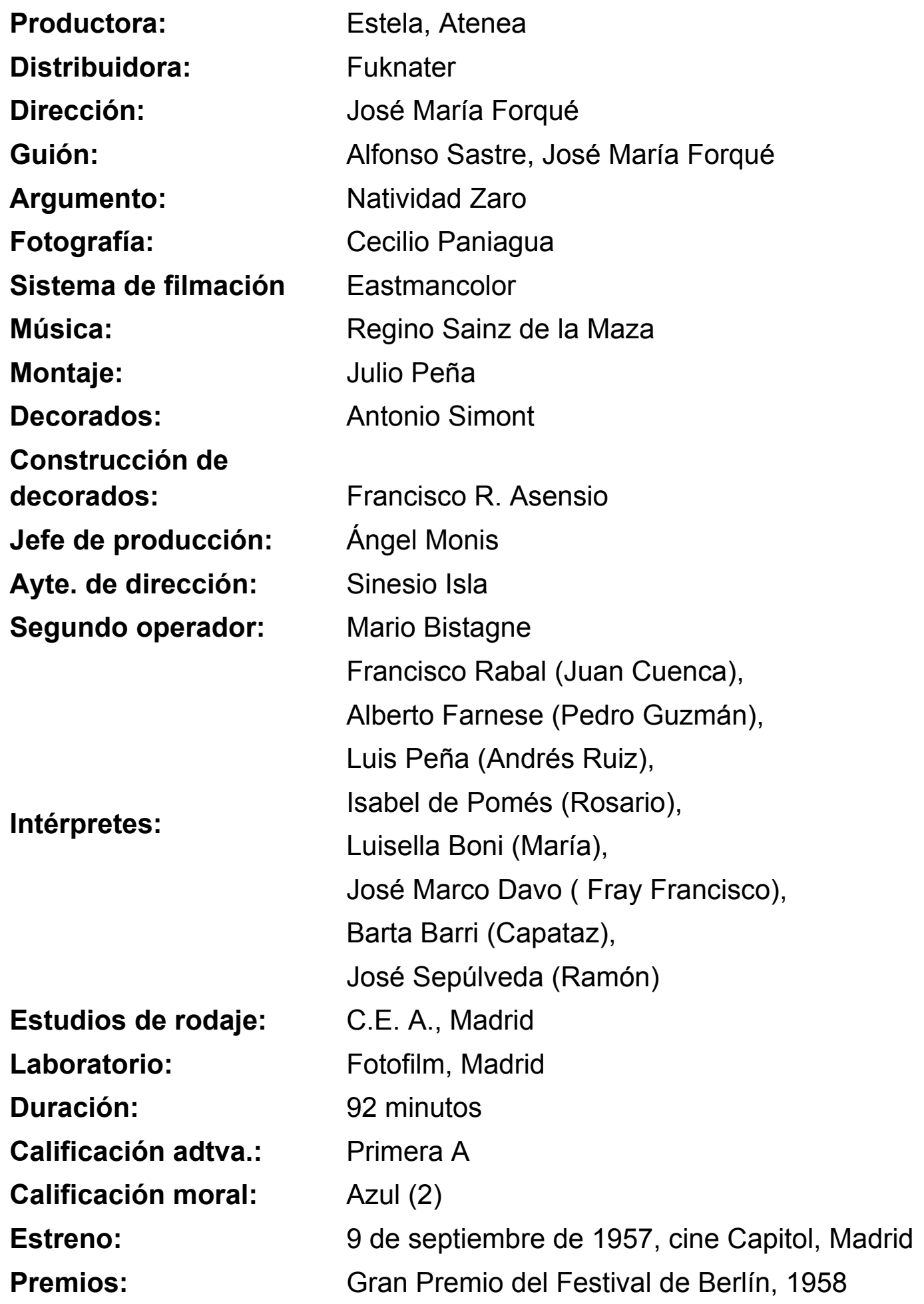




\section{A. BIBLIOGRAFÍA}

Cincuenta años en el campo. 1909-1959. Madrid: Vidaurreta y Cía, S.A.

Congreso de electrificación rural. (1948). [Libro de actas]. Volumen Primero. Madrid: Publicaciones de Luz y Fuerza.

Arquitectura en Regiones Devastadas. [Catálogo de exposición]. Dirección General de Arquitectura y Edificación; Subdirección General de Arquitectura y Servicio de Fomento de la Arquitectura, MOPU. (s.f). Madrid: Ministerio de Obras Públicas y Urbanismo.

Aguilar, C. (1988). El campo en el cine español. Valencia: Filmoteca de la Generalitat Valenciana. Banco de Crédito Agrícola.

Alomar, G. (1955). Comunidad planeada. Principios de sociología aplicada al urbanismo y al planeamiento rural. Madrid: Instituto de Estudios de Administración Local.

Alonso, L.E.; Arribas, J.M.; Ortí, A. (1991). Evolución y perspectivas de la agricultura familiar: de «propietarios muy pobres» a agricultores empresarios. En Política y sociedad. (8), 35-70.

Álvarez, J.; Ibarrola, A.; Monterde J.E. (1991). Ciao, Za. Zavattini en España. [Catálogo de exposición]. Valencia: Filmoteca de la Generalitat Valenciana.

Amador, P.; Ruiz, R. (eds.). (2007). La otra dictadura. El régimen franquista y las mujeres. Madrid: Universidad Carlos III, Instituto de Cultura y Tecnología.

Anderson, B. (2005). Comunitats imaginades: reflexions sobre l'origen i la propagació del nacionalisme. València: Afers. Universitat de València.

Arielza, J.M. (1947). Embajadores sobre España. Madrid: Instituto de Estudios Políticos.

Aries, P. (1988) [1954]. El tiempo de la historia. Barcelona: Paidós.

Aristóteles. (1925) [IV.a.C]. La política. Valencia: Prometeo.

Arocena Badillos, C. (2010). Cuando Manuel miró a la mujer. Las 
protagonistas femeninas en el cine de Manuel Mur Oti. En Quaderns de cine. (5), 9-16.

Ascunce Arrieta, J. A. (2015). Sociología cultural del franquismo (1936-1975). La cultura del nacional-catolicismo. Madrid: Biblioteca Nueva.

Azorín. (2011) [1905]. Los pueblos. Madrid: Alianza editorial.

Azorín. (2013) [1905]. La ruta de don Quijote. Madrid: Alianza Editorial.

Azorín. (1913). Los valores literarios. Madrid: Renacimiento.

Azorín. (1919). El alma castellana. Madrid: Club Internacional del Libro.

Azorín. (1920) [1909]. España. Hombres y paisajes. Madrid: Rafael Caro Raggio.

Ballesteros, I. (2001). Cine (ins)urgente: textos filmicos y contextos culturales de la España posfranquista. Madrid: Fundamentos.

Barciela, C.; López, M.I.; Melgarejo, J.; Miranda, J.A. (2001). La España de Franco. 1939-1975: Economía. Madrid: Editorial Síntesis.

Berque, A. (dir.) (1994). Cinq propositions pour une théorie du paysage. 15. Seyssel, Francia : Champ Vallon.

Benet, J. (1987). Otoño en Madrid hacia 1950. Madrid: Alianza Tres.

Benet, V. (2012). El cine español. Una historia cultural. Barcelona: Paidós Comunicación.

Benet, V. (2014). Melodrama e imaginación romántica: en torno a la adaptación de Entre naranjos en Hollywood. En Revista de Estudios sobre Blasco Ibáñez. (3), 103-118.

Besas, P. (1985). Behind the Spanish Lens. Spanish Cinema under Fascism \& Democracy. Estados Unidos de América: Arden Press.

Blasco lbáñez, B. (2016) [1902]. Cañas y barro. Madrid: Alianza Editorial.

Borau, J.L. (dir.). (1998). Diccionario del cine español. Madrid: Alianza Editorial.

Bordieu, P. (1989). Reproduction interdite. La dimension symbolique de la domination économique. En Études rurales. (113-114), 15-35. 
Calvo Salgado, L.M.; Fernández Vicente, M.J.; Kreienbrink, A.; Sanz Díaz, C.; Sanz Lafuente, G. (2009). Historia del Instituto Español de Emigración. La política migratoria exterior de España y el IEE del Franquismo a la Transición. Madrid: Ministerio de Trabajo e Inmigración.

Carus, C.G. (1992). Cartas y anotaciones sobre la pintura de paisajes. Madrid: La balsa de la Medusa.

Castro de Paz, A. (1974). El cine español en el banquillo. Valencia: Fernando Torres.

Castro, J.L.; Pérez Perucha, J. (coords.). (1999). El cine de Manuel Mur Oti. Ourense: IV Festival Internacional de Cine Independiente de Ourense.

Castro de Paz, J.L.; Pérez Perucha, J.; Zunzunegui, S. (2005). Historias del cine español. La nueva memoria. (1939-2000). A Coruña: Vía Láctea.

Cazorla, A. (2016). Miedo y progreso. Los españoles de a pie bajo el franquismo. 1938-1975. Madrid: Alianza editorial.

Cirici, A. (1977). La estética del franquismo. Barcelona: Gustavo Gili, S.A.

Clark, K. (1971). El arte del paisaje. Biblioteca Breve. Barcelona: Seix Barral.

Clavera, J.; Esteban, J. M.; Monés, M.A.; Montserrat, A.; Ros Hombravella, J. (1978). Capitalismo español: de la autarquía a la estabilización, 19391959. Madrid: Edicusa.

Cosgrove, D.E. (1998). Social Formation and Symbolic Landscape. Londres, Reino Unido: University of Wisconsin Press.

Crainz, G. (1998). Storia del miracolo italiano. Cultura, identità, trasformazioni fra anni cinquanta e sessanta. Roma: Donzelli.

Crang, M. (1998). Cultural Geography. Contemporary Human Geography Series. Londres: Routledge.

Davies, A. (ed.). (2011). Spain on Screen. Developments in Contemporary Spanish Cinema. Basingtoke, Nueva York: Palgrave Macmillan.

Davies, A. (2012). Spanish Spaces. Landscape, Space and Place in Contemporary Spanish Culture. Liverpool: Liverpool University Press. 
Davies, R. (2018). Space and Place in Alejandro Galindo's 1950 Film Adaptaion of Benito Pérez Galdós's Doña Perfecta (1876). Bulletin of Spanish Studies. 95 (4), 417-434.

de Areilza, J. M. (s. f.). Embajadores sobre España. Madrid: Instituto de Estudios Políticos.

de Lucas, G.; Elduque, A. (2017). El Star System desde Europa. Actualidad de los Star Studies. Cinema Comparat/ive Cinema, V. (10), 26-35.

de Unamuno, M. (1968) [1895]. En torno al casticismo. Madrid: EspasaCalpe.

de Unamuno, M. (2018) [1922]. Andanzas y visiones españolas. 14. Madrid: Alianza.

de Unamuno, M. (1944) [1944]. Paisajes del alma. Madrid: Revista de Occidente.

de Unamuno, M. (2014). Viajes y paisajes. Antología de crónicas de viaje. España: La línea del horizonte ediciones.

del Molino, S. (2016). La España vacía. Viaje por un país que nunca fue. Madrid: Turner Noema.

Díaz-Plaja, G. L. (1974). La condición emigrante. Los trabajadores españoles en Europa. Madrid: Edicusa.

Díaz Sánchez, J. (2013). La idea de arte abstracto en la España de Franco. Madrid: Cátedra.

Eliade, M. (1981). Tratado de historia de las religiones. Madrid: Ediciones Cristiandad.

Fanés, F. (1982). Cifesa. La antorcha de los éxitos. Valencia: Instituto Alfonso el Magnánimo.

Faulkner, S. History of Spanish Filme. Cinema and Society 1910-2010. Londres: Bloomsbury Academic.

Ferro, M. (1995). Historia contemporánea y cine. Barcelona: Ariel.

Ford, R. (1845). Hand-Book for Travellers in Spain and readers at home. 
Describing the Country and Cities, the Natives and Their Manners; the Antiquities, Religion, Legends, Fine Arts, Literature, Sports, and Gastronomy. With Notices on Spanish History. Londres, Reino Unido: John Murray.

Ford, R. (2008). Manual para viajeros por España y lectores en casa. Sobre el país y sus ciudades, costumbres de sus habitantes, su religión y sus leyendas, las bellas artes, la literatura, los deportes, la gatronomía y diversas noticias sobre su historia. Madrid: Turner Publicaciones S. L.

Fowler, C.; Helfield, G. (2006). Representing the Rural. Space, Place and Identity in Films about the Land. Detroit, EUA.: Wayne State University Press.

Fox, S. (2010). Violence and Silence: The Repressed History of the Franco Regime. En Unhearthing Franco's Legacy. Indiana, EUA.: University of Notre Dame.

Franco Giner, J. (2000). Cifesa, mite i modernitat: Els anys de la República. València: L'Eixam.

Galeski, B. (1977). Sociología del campesinado. Barcelona: Peníncula.

Gallego, F. (2014). El evangelio fascista. La formación de la cultura política del franquismo. (1930-1950). Barcelona: Crítica. Contrastes.

García Carrión, M. (2007). Sin cinematografía no hay nación: Drama e identidad nacional española en la obra de Florián Rey. Zaragoza: Institución Fernando el Católico, CSIC.

García Carrión, M. (2013a). El pueblo español en el lienzo de plata: nación y región en el cine de la II República. En Hispania. Revista Española de Historia, LXXIII. (243), 193-222.

García Carrión, M. (2013b). Lugares de entretenimiento, espacios para la nación: cine, cultura de masas y nacionalización en España (1900-1936). En Ayer 90. Revista de Historia Contemporánea. (2), 115-137.

García de León, M. A. (1992). La ciudad contra el campo. 77. Ciudad Real: Diputación Provincial de Ciudad Real-Área de Cultura, Biblioteca de Autores y temas manchegos. 
García Escudero, J.M. (1954). La historia del cine en cien palabras y otros escritos de cine. Cine-club del SEU de Salamanca.

García Escudero, J.M. (1962). Cine español. Madrid: Rialp.

Giménez Martínez, M.A. (2014). El estado franquista. Fundamentos ideológicos, bases legales y sistema institucional. Madrid: Centro de Estudios Políticos y Constitucionales.

Gómez Rufo, A. (1990). Berlanga, contra el poder y la gloria. Madrid: Temas de hoy.

Gómez Benito, C.; Luque Pulgar, E. (ed.). Imágenes de un mundo rural. 1955-1980. Madrid: Ministerio de Agricultura, pesca y alimentación.

Gracia, C. (2000). Història de l'art del segle XIX. València: Universitat de València.

Gracia, J.; Ruiz Carnicer, M. A. (2001). Historia de España (1939-1975). Cultura y vida cotidiana. Madrid: Síntesis, D.L.

Gracia, J. (2004). La resistencia silenciosa. Fascismo y cultura en España. Barcelona: Anagrama. Colección Argumentos.

Graham, H. Labanyi, J. (ed.). (1995). Spanish Cultural Studies: An Introduction. The Struggle for Modernity. Reino Unido; Nueva York: Oxford University Press.

Gubern, R.; Font, D. (1975). Un cine para el cadalso. Barcelona: Editorial Euros.

Gubern, R. (1981). La Censura. Función política y ordenamiento jurídico bajo el franquismo (1936-1975). Barcelona: Península.

Gubern, R.; Monterde, J.E.; Pérez Perucha, J.; Riambau, E.; Torreiro, C. (ed.) (1995). Historia del cine español. Signo e Imagen, 40. Madrid: Cátedra.

Gutiérrez Solana, J. (1920). La España negra. Madrid.

Harper. G.; Rayner, J. (2010). Cinema and landscape. Film, Nation and Cultural Geography. Chicago, EUA.: University of Chicago Press Books.

Heredero, C.F. (1993). Las huellas del tiempo. Cine español 1951-1961. 
Documentos, 5. España: Filmoteca de la Generalitat Valenciana. Filmoteca Española. Ministerio de Cultura.

Heredero, C.F.; Monterde, J. E. (eds). (2003). Los nuevos cines en España: Ilusiones y desencantos de los años sesenta. Valencia: Institut Valencià de la Cinematografia y el Audiovisual y Festival Internacional de Cine de Gijón.

Hernández, M.; Revuelta, M. (1976). 30 años de cine al alcance de todos los españoles. Bilbao: Zero, S.A.

Herzog, M. (1967). La montaña. México: Labor.

Jiménez-Blanco, M.D. (Com.) (2016). Campo cerrado. Arte y poder en la posguerra española. 1939-1953. Madrid: Museo Nacional Centro de Arte Reina Sofia.

Juliá, S. (1996). Anomalía, dolor y fracaso de España. En Claves de Razón Práctica, 66, 10-21.

Juliá, S. (dir.). (1997). Memoria del 98. De la guerra de Cuba a la Semana Trágica. Madrid: El Pais, Central Hispano.

Kinder, M. (1993). Blood Cinema. The Reconstruction of National Identity in Spain. Berkley- Los Angeles: University of California Press.

Kovács, S. K. (1991) The plain in Spain: Geography and national identity in Spanish cinema. Quarterly Review of Film and Video (13).Núm.4, 17-4

Labanyi, J.; Pavlovic, T. (ed.) A Companion to Spanish Cinema. Estados Unidos de América: Wiley-Blackwell.

Laín Entralgo, P. (1945). La Generación del noventa y ocho. Madrid: Diana. Artes Gráficas.

Laín Entralgo, P. (1948). La Generación del 98 y el problema de España.Arbor, 36 (XI), 417- 438.

Lefebvre, H. (1991). The Production of Space. Oxford, Reino Unido: Basil Blackwell Ltd.

Lefebvre, M. (2006). Landscape and Film. Nueva York: Routledge. 
Legendre, M. (1927). Las Jurdes. Étude de Géographie humaine. Bordeaux. Paris: Feret \& Fils, Éditeurs.

López Amo, A. (1987). El poder político y la libertad. La monarquía de la reforma social. Naturaleza e Historia, 52. Madrid: Rialp.

López Clemente, J. (1981). Directores españoles de ayer. Manuel Mur Oti. En Arte Fotográfico, (núm. 354), 754-759.

López Mondéjar, P. (1997). Historia de la fotografía en España. Fotografía y sociedad, desde sus orígenes hasta el siglo XXI. Barcelona: Lunwerg.

Maderuelo, J. (2005). El paisaje. Génesis de un concepto. Madrid: Abada Editores.

Magris, C. (2008). El infinito viajar. Barcelona: Anagrama.

Mainer, J.C. (1994). De postguerra (1951-1990). Barcelona: Crítica.

Martínez Bretón, J. A. (1987). Influencia de la Iglesia Católica en la cinematografía española: 1951-1962. Madrid: Harofarma.

Martínez de Pisón, E. (2000). Estudios sobre el paisaje. Colección de estudios, 67. Madrid: Universidad Autónoma de Madrid.

Marzo, J.L. (2007). Art modern i franquisme. Els orígens conservadors de l'avantguarda i de la política artística a l'estat espanyol. Girona: Fundació Espais d'Art Contemporani.

Marzo, J.L. (2010). ¿Puedo hablarle con libertad, excelencia? Arte y poder en España desde 1950. Murcia: CENDEAC.

Marx, K. (2003) [1852]. El dieciocho brumario de Luis Bonaparte. Madrid: Alianza.

Matless, D. (2016). Arts of Living: Landscape and Citizenship, 1918-39. En Landscape and Englishness.London: Reaktion Books, 94-144.

Milani, R. (2008). El arte del paisaje. Paisaje y Teoría. Biblioteca Nueva. Madrid: Edición de Federico López Silvestre.

Monterde. J.E.; Riambau, E.; Torreiro, C. (1987). Los «nuevos cines» europeos 1955/1970. Barcelona: Lerna. 
Monterde, J. E.; Riambau, E.; Amengual, B. (1996). Historia general del cine, volumen VII: Europa y Asia (1929-1945). Madrid: Cátedra.

Nasu, M. (2013). Contesting Visions. Memory and Cultural Traume in Early Post-Civil War. Spanish Cinema 1939-1950. [Tesis doctoral inédita]. Reino Unido: Royal Holloway University of London.

Newland, P. (ed.). (2016). British Rural Landscape on Film. Reino Unido: Manchester University Press.

Nieto Ferrando, J.; Company, J. M. (coord). (2006). Por un cine de lo real. Cincuenta años después de las Conversaciones de Salamanca. Documentos, 12. Valencia: Ediciones de La Filmoteca, Generalitat Valenciana.

Nieto Ferrando, J. (2009). Cine en papel: Cultura y crítica cinematográfica en España (1939-1962). Textos, 42. Valencia: Ediciones de La Filmoteca. Generalitat Valenciana.

Ortas Durand, E. (1999). Viajeros ante el paisaje aragonés (1759-1850). Zaragoza: Institución Fernando el Católico, Diputación de Zaragoza.

Ortega Cantero, N. (2006). Imágenes del paisaje. Madrid: Universidad Autónoma de Madrid.

Otero Urtaza, E. (ed.) (2006). Las misiones pedagógicas. 1931-1936. Madrid: Sociedad Estatal de Conmemoraciones Culturales- Residencia de estudiantes.

Ortiz-Echagüe, J. (2014). Mundo Hispánico versus Life: 'Spanish Village' by Eugene Smith and the Debate over Spain in Illustrated Magazines (19491952). En Communication \& Society. (27), núm. 1, 23-57.

Pérez Bowie, J.A.; González García, F. (2010). El mercado vigilado. La adaptación en el cine español de los 50. Murcia: Tres Fronteras Ediciones. Consejería de Cultura y Turismo Región de Murcia.

Pérez Gómez, A.; Martínez Montalbán, J.L. (1978). Cine español 1951/1978. Diccionario de directores. Bilbao: Mensajero.

Pérez Lozano, J.M. (dir.). Guía cinematográfica y de películas estrenadas. 1961. Madrid: Cinestudio Ediciones. 
Pérez Merinero, C. y D. (1975). Cine y control. Madrid: Castellote Editor.

Pérez Perucha, J. (ed.). (1981). Berlanga 2. Valencia: Ayuntamiento de Valencia.

Pérez Perucha, J. (coord.). (1997). Antología crítica del cine español: 19061995. Flor en la sombra. Madrid: Cátedra. Filmoteca Española.

Pérez Picazo, M. T. (1996). Historia de España del siglo XX. Nuevos instrumentos universitarios. Barcelona: Crítica.

Poyato, P. (ed.). (1998). El realismo y sus formas en el cine rural español. IV Muestra de Cine Rural. Dos Torres, Córdoba. 2-6 de octubre 2006. Córdoba: Diputación Provincial de Córdoba, Ayuntamiento de Dos Torres.

Poyato, P. (ed.). (2007). Lo rural en el cine español. III Muestra de Cine Rural. Dos Torres, Córdoba. 5-7 de octubre 2007. Córdoba: Diputación Provincial de Córdoba, Ayuntamiento de Dos Torres.

Poyato, P. (ed.). (2010). Clásicos del cine rural español. VII Muestra de Cine Rural. Dos Torres, Córdoba. 28-30 de octubre 2009. Córdoba: Diputación Provincial de Córdoba, Ayuntamiento de Dos Torres.

Preston, P. (ed.) (1976). Spain in crisis. The Evolution and Decline of the Franco Regime. Reino Unido: Harvester Press, Hassocks.

Publio, L.M. (1999). Historia de la fotografía en España. España: Luwerg Editores.

Rhodes, J.D.; Gorfinkel, E. (ed.). (2011). Taking Place. Location and the Moving Image. Minneapolis. Londres: University of Minnesota Press.

Riambau, E. ( 2007). Ricardo Muñoz Suay. Una vida en sombras. Edición Especial, 38. Valencia: Tusquets Editores; IVAC La Filmoteca.

Riambau, E. Torreiro, C. (2008). Productores en el cine español. Estado, dependencias y mercado. Madrid: Cátedra. Filmoteca Española.

Richards, M. (1996). Time of Silence. Civil War ant the Culture of Repression in Franco's Spain 1936-1945. Cambridge, Reino Unido: Cambridge University Press. 
Richards, M. (2010). Grand Narratives, Collective Memory, and Social History: Public Uses of the Past in Post-War Spain. En Unearthing Franco's Legacy. Indiana, Estados Unidos de América: University of Notre Dame, 121-145.

Richardson, N. (2012). Constructing Spain. The Re-Imagination of Space and Place in Fiction and Film, 1953-2003. Reino Unido: Bucknell University Press.

Rubio. A. (2013). Vicente Escrivá. Película de una España. Documentos, 18. Valencia: Ediciones de la Filmoteca-CulturArts.

Rubio Jiménez, J. (ed). (1992). Actas del congreso 'Los Bécquer y el Moncayo'. Tarazona y Veruela, septiembre 1990. Zaragoza: Instituto Fernando el Católico.

Ryan, L. (2014). Rurality, the Second Space, and Global Memory Structures in Bernardo Atxaga's El hijo del acordeonista. En A. J. Cruz (ed.), Memory and Spatiality in Post-Millenial Spanish Narrative. Farnham, Reino Unido: Ashgate, 159-176.

Salvadó Romero, A. (2012). Estètica del paisatge cinematogràfic. El découpage i la imatge en moviment com a formes de representació paisajística. [Tesis doctoral inédita]. Barcelona: Universitat Pompeu Fabra.

Sánchez Vidal, A. (1991). El cine de Florián Rey. Zaragoza: Caja de Ahorros de la Inmaculada Aragón.

Saura, C. (2016). España años 50. Madrid: Steidl, Círculo del Arte, La Fábrica.

Saz, I.; Archilés, F. (2012). La nación de los españoles. Discursos y prácticas del nacionalismo español en la época contemporánea. Valencia: Universitat de València.

Sender, R. J. (2016) [1934]. Viaje a la aldea del crimen. Barcelona: Libros del Asteroide.

Serna J.; Pons, A. (2013). La historia cultural. Autores, obras, lugares. Salamanca: Akal. 
Shubert, A. (1996). A Social History of Modern Spain. Nueva York, EUA.: Routledge.

Stone, R. (2001a). Leaving the church. Early Spanish cinema. En Spanish Cinema. Florencia, Italia: Taylor and Francis, 40-79.

Stone, R. (2001b). Under Franco. Spanish cinema during the dictatorship. En Spanis Cinema. Florencia, Italia: Taylor and Francis, 80-119.

Suárez Carreño, J. (1952). Condenados. Madrid: Ediciones Alfil.

Tamames, R. (1977). La República. La Era de Franco. Madrid: Alianza Editorial.

Torrente Ballester, G. (1965). Panorama de la literatura española contemporánea. Madrid: Guadarrama.

Triana-Toribio, N. (2003). Spanish National Cinema. Londres- Nueva York: Routledge. Taylor and Francis.

Tusell, J. (1984). Franco y los católicos. La política interior española entre 1945 y 1957.

Verhaeren, E. (1924) [1898]. La España negra de Verhaeren. Cuadernos literarios, 3. Madrid: Ciudad Lineal.

Williams Evans, P. (ed.). (1999). Spanish Cinema. The Auteurist Tradition. Oxford University Press.

Whittaker, T. (2011). The Films of Elias Querejeta. A producer of Landscapes. Reino Unido: University of Wales Press.

Yuval-Davis, N. (1997). Gender \& Nation. Reino Unido: SAGE Publications Ltd.

Zavattini, C.; Berlanga, L.; Muñoz Suay, R. (1991). Cinco historias de España y Festival de cine. Valencia: Filmoteca de la Generalitat Valenciana.

Zubiaur Gorozika, N. E. (2013). Anatomía de un cineasta pasional. El cine de Manuel Mur Oti. Textos aparte(2). Santander-Cantabria: Shangrila. 


\section{B. REVISTAS Y PERIÓDICOS}

\section{Arriba}

17 de marzo de 1950.

29 de junio de 1955.

\section{Arte Fotográfico}

Núm. 354, 757.

Boletín de las Primeras Conversaciones cinematográficas Nacionales Núm. 6, 17 de mayo de 1955.

\section{Cinema Universitario}

Núm. 1, marzo de 1955.

Núm. 2, diciembre de 1955.

Núm. 4, diciembre de 1956.

Núm. 6, diciembre de 1957.

Núm. 8, diciembre de 1958.

Núm. 9, abril de 1959.

\section{Cinestudio}

Núm. 82, febrero 1970.

\section{Contracampo}

Núm. 24, 1981.

\section{Ecclesia}

Núm. 148, 13 de mayo de 1944.

\section{El País}

14 de octubre de 1983.

F.E.

Núm. 12, 26 de abril de 1936, 6-7.

\section{Film Ideal}

Núm. 20, junio de 1958.

Núm. 29, marzo de 1959. 


\section{Índice}

Núm. 48, febrero de 1952.

Núm. 53, julio de 1952.

Núm. 64, junio de 1953.

Núm. 68-69, octubre-noviembre de 1953.

Núm. 72, febrero de 1954.

\section{Luz}

Noviembre de 1898.

\section{Objetivo}

Núm. 2, enero de 1955.

Núm. 5, mayo de 1955.

Núm. 6, junio de 1955.

Núm. 7, julio de 1955.

\section{Primer Plano}

Núm. 540, febrero de 1951.

Núm. 651. Año XIII, 5 de abril de 1953.

Núm. 664 .Año XIII, 5 de julio de 1953.

Núm. 665. Año XIII, 12 de julio de 1953.

Núm. 670. Año XIII, 16 de agosto de 1953.

Núm. 673. Año XIII, 6 de septiembre de 1953.

Núm. 676. Año XIII, 27 de septiembre de 1953.

Núm. 680. Año XIII, 25 de octubre de 1953.

Núm. 706. Año XIV, 25 de abril de 1954.

Núm. 711. Año XIX, 30 de mayo de 1954.

Núm. 730. Año XIV, 10 de octubre de 1954.

Núm. 739. Año XIV, 12 de diciembre de 1954.

Núm. 742. Año XV, 2 de enero de 1955.

Núm. 772. Año XV, julio de 1955.

Núm. Indefinido. Año XVII, 16 de junio de 1957.

\section{Radiocinema}

Núm. 190, marzo de 1954.

Núm. 198, marzo de 1954.

Núm. 203, junio de 1954.

Núm. 215, septiembre de 1954.

Núm. 217, septiembre de 1954.

Núm. 224, noviembre de 1954.

Núm. 229, noviembre 1954. 
Núm. 236, enero de 1955.

Núm. 237, febrero de 1955.

Reconstrucción. Dirección General de Regiones Devastadas y Reparaciones

Núm. extraordinario junio-julio 1940.

Núm. 4, noviembre de 1940.

Núm. 5, octubre de 1940.

Núm. 8, marzo de 1941. Año II.

Núm. 9, febrero de 1941. Año II.

Núm. 10, marzo de 1941. Año II.

Núm. 18, diciembre de 1941. Año II.

Núm. 31, marzo de 1943. Año IV.

Núm. 127. 1955.

\section{Signo}

Núm. 788, febrero de 1955.

\section{Visor}

Núm. 2, 30 de noviembre de 1959. 


\section{FILMOGRAFÍA}

Tierra sedienta. Rafael Gil, 1945.

Las aguas bajan negras. José Luis Sáenz de Heredia, 1948.

Un hombre va por el camino. Manuel Mur Oti, 1949.

Vértigo. Casta andaluza. Eusebio Fernández-Ardavín, 1950.

María Morena. José María Forqué, 1951.

Surcos. Antonio Nieves Conde, 1951.

La Laguna Negra. Arturo Ruiz-Castillo, 1952.

Bienvenido Mr. Marshall. Luis García Berlanga, 1952.

Puebla de las mujeres. Antonio del Amo, 1952.

Agua sangrienta. Ricardo Torres, 1952.

Estrella de Sierra Morena. Ramón Torrado, 1952.

Condenados. Mur Oti, 1953.

Carne de horca. Ladislao Vadja, 1953.

El alcalde de Zalamea. José García Maesso, 1953.

La montaña sin ley. Miguel Lluch, 1953.

Como la tierra. Alfredo Hurtado, 1953.

La guerra de Dios. Rafael Gil, 1953.

El andén. Eduardo Manzanos, 1953.

Cañas y barro. Juan de Orduña, 1954.

El padre Pitillo. Juan de Orduña, 1954.

Llegaron siete muchachas. Domingo Viladomat, 1954.

Sierra maldita. Antonio del Amo, 1954.

Viento del Norte. Antonio Momplet, 1954.

Un caballero andaluz. Luis Lucia, 1954.

Nosotros dos. Emilio Fernández, 1954.

Cinco historias de España (proyecto), Cesare Zavattini, Luis G. Berlanga y

Ricardo Muñoz Suay, 1954.

La pícara molinera. León Klimovsky, 1955.

Orgullo. Manuel Mur Oti, 1955.

Cancha vasca. Alfredo Hurtado, 1955.

Calabuch. Berlanga, 1956.

¡Aquí hay petróleo!. Rafael J. Salvia, 1956. 
La gata. Rafael Torrecilla y Margarita Aleixandre, 1956.

Duelo de pasiones. Javier Setó, 1956.

La venganza. J. A. Bardem, 1957.

Un indiano en Moratilla. León Klimovsky, 1957.

Amanecer en Puerta Oscura. José María Forqué, 1957.

El ruiseñor de las cumbres. Antonio del Amo, 1958.

Soledad. Mario Craveri y Enrico Gras, 1958.

El puente de la paz. Rafael J. Salvia, 1958. 
